\title{
Genotypic and phenotypic effects of c-Ha-ras oncogene transfection on human colorectal carcinoma cell lines
}

Citation for published version (APA):

de Vries, J. E. (1993). Genotypic and phenotypic effects of c-Ha-ras oncogene transfection on human colorectal carcinoma cell lines. [Doctoral Thesis, Maastricht University]. Rijksuniversiteit Limburg. https://doi.org/10.26481/dis.19931210jd

Document status and date:

Published: 01/01/1993

DOI:

10.26481/dis.19931210jd

Document Version:

Publisher's PDF, also known as Version of record

Please check the document version of this publication:

- A submitted manuscript is the version of the article upon submission and before peer-review. There can be important differences between the submitted version and the official published version of record.

People interested in the research are advised to contact the author for the final version of the publication, or visit the DOI to the publisher's website.

- The final author version and the galley proof are versions of the publication after peer review.

- The final published version features the final layout of the paper including the volume, issue and page numbers.

Link to publication

\footnotetext{
General rights rights.

- You may freely distribute the URL identifying the publication in the public portal. please follow below link for the End User Agreement:

www.umlib.nl/taverne-license

Take down policy

If you believe that this document breaches copyright please contact us at:

repository@maastrichtuniversity.nl

providing details and we will investigate your claim.
}

Copyright and moral rights for the publications made accessible in the public portal are retained by the authors and/or other copyright owners and it is a condition of accessing publications that users recognise and abide by the legal requirements associated with these

- Users may download and print one copy of any publication from the public portal for the purpose of private study or research.

- You may not further distribute the material or use it for any profit-making activity or commercial gain

If the publication is distributed under the terms of Article $25 \mathrm{fa}$ of the Dutch Copyright Act, indicated by the "Taverne" license above, 


\section{GENOTYPIC AND PHENOTYPIC EFFECTS OF C-HA-RAS ONCOGENE TRANSFECTION ON HUMAN COLORECTAL CARCINOMA CELLS}


De druk van dit proefschrift werd financieel ondersteund door de Stichting Klinische Pathologie Zuid-Limburg en BioRad. 


\section{GENOTYPIC AND PHENOTYPIC EFFECTS OF C-HA-RAS ONCOGENE TRANSFECTION ON HUMAN COLORECTAL CARCINOMA CELLS}

\section{PROEFSCHRIFT}

ter verkrijging van de graad van doctor

aan de Rijksuniversiteit Limburg te Maastricht, op gezag van de Rector Magnificus, Profdr. H. Philipsen, volgens het besluit van het College van Dekanen, in het openbaar te verdedigen

op vrijdag, 10 december 1993 om 16.00 uur

door

Johannes Erik de Vries 


\section{Promotores:}

Prof.dr. F.T. Bosman

Prof.dr: J P.M Geraedts

\section{Co-promotor:}

Dr. J. ten Kate

\section{Beoordelingscommissie:}

Prof.dr. F.C.S. Ramaekers (voorzitter)

Prof.dr. C.H.C.M. Buys (Rijksuniversiteit Groningen)

Prof.dr. D.J. Ruiter (Katholieke Universiteit Nijmegen)

Prof.dr. J.F.M. Smits

Prof.dr. R.W. Stockbrügger 
"De essentie is dat een mens in wezen niet verandert, nog steeds het jongetje wan zeventien is dat de wereld met grote belangstelling en nieuwsgierigheid gadeslaat"

Opland, 1993.

In herinnering aan mijn vader

Aan mijn moeder

Voor Mieke 



\section{CONTENTS}

\section{Chapter 1}

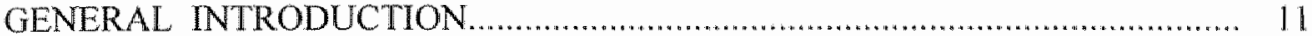

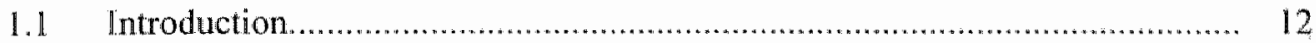

1.2 Invasion and metastasis................................................................... 12

1.2.1 Characteristics of the invasive and metastatic cell.......................... 12

Proliferation, genetic instability, and tumor cell heterogeneity........ 13

Proteases........................................................................................... 15

Cell adhesion molecules.................................................................... 16

Dissemination of tumor cells....................................................... $\quad 19$

1.2.2 Tools to investigate invasion and metastasis.................................. 20

Patient material...................................................................... 20

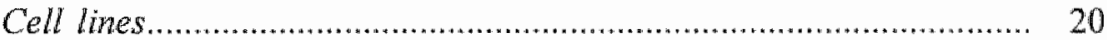

In vitro madels............................................................................. 21

In vivo models.......................................................................... 21

1.3 The c-Ha-ras oncogene .................................................................. 21

1.3.1 Structure, function, and expression of the c-Ha-ras gene................ 21

1.3.2 Regulation of the c-Ha-ras protein activity.................................... 24

1.3.3 Growth factors and $\mathrm{p} 21$ ras proteins in signal transduction pathways 26

1.3.4 Mutations in the c-Ha-ras gene ................................................. 29

1.3.5 Effects of the introduction of the c-Ha-ras oncogene in cell lines.... 30 Fibroblasts................................................................................ 30

Mammary, prostate, and bladder cells........................................... 31

Keratinocytes and hepatocytes................................................... 32

Lymphocytes...................................................................... 32

Neuroendocrine cells................................................................. 32

Muscle cells and melanocytes.................................................... 32

1.3.6 The c-Ha-ras oncogene in colorectal cancer.................................... 33

1.4 A.m and design of the study ....................................................... 34

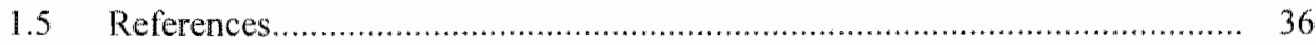

\section{Chapter 2}

BEHAVIOR OF ORTHOTOPIC HUMAN COLORECTAL CARCINOMA XENOGRAFTS IN RELATION TO IN VITRO INVASION. 


\section{Chapter 3}

CHROMOSOMAL LOCALIZATION OF TRANSFECTED GENES

BY A COMBINATION OF HOT BANDING AND FLUORESCENCE

IN SITU HYBRIDIZATION.

\section{Chapter 4}

TRANSFECTED C-HA-RAS ONCOGENE ENHANCES

KARYOTYPIC INSTABILITY AND INTEGRATES PREDOMINANTLY

IN ABERRANT CHROMOSOMES.

\section{Chapter 5}

PHENOTYPIC ANALYSIS OF CACO 2 AND SW 480

CELL LINES TRANSFECTED WITH THE C-HA-RAS ONCOGENE.

\section{Chapter 6}

HUMAN CACO 2 CELLS TRANSFECTED WITH C-HA-RAS AS A MODEL FOR ENDOCRINE DIFFERENTIATION IN THE LARGE INTESTINE.

\section{Chapter 7}

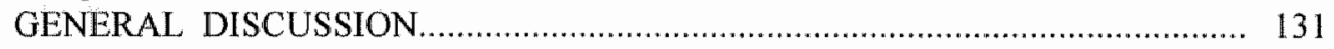

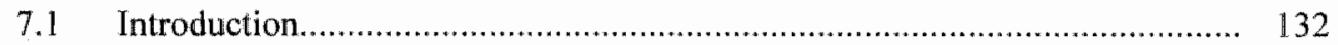

7.2 Orthotopic xenografts:

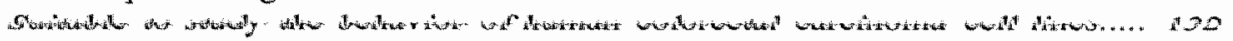

7.3 Genetic instability in colorectal carcinoma:

The influence of the c-Ha-ras oncogene.

7.4 The role of the c-Ha-ras oncogene in colorectal carcinoma:

Effects on growth and differentiation................................................ 135

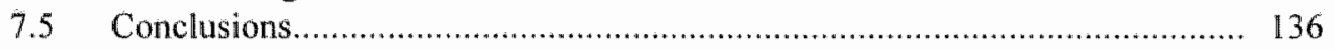

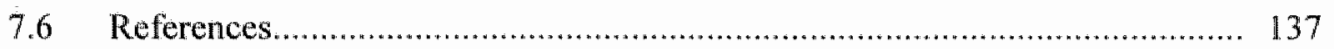

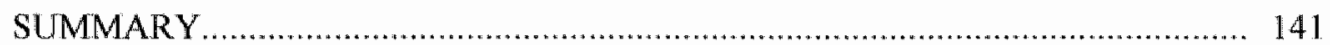

SAMENVATTING VOOR DE LEEK ........................................................... 143 


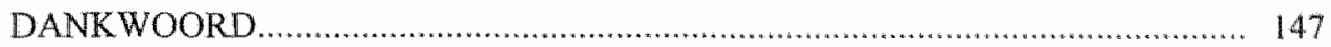

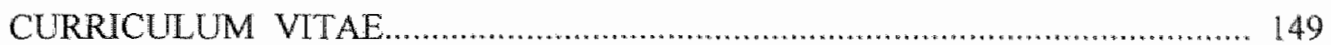

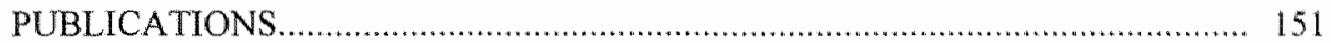





\section{CHAPTER 1}

GENERAL INTRODUCTION 


\subsection{INTRODUCTION}

Colorectal cancer is one of the most common forms of cancer in Western Europe. It is third next to lung cancer and prostate cancer in males, and second to breast cancer in females $(1,2)$. In the Netherlands colorectal cancer accounts for $10 \%$ and $14 \%$ of the cancer deaths in men and women, respectively (2). The development of metastatic lesions from primary tumors is the main cause of failure in the treatment of colorectal tumors. The lack of fundamental understanding as to how tumor invasion, which preceeds metastasis, and metastasis itself occur is one of the factors which hamper further advancement in therapy. Therefore, in current cancer research much attention is paid to the molecular mechanisms of tumor progression, including mechanisms of invasion and metastasis.

It has been demonstrated that genes, which normally regulate cellular proliferation and differentiation such as the family of the ras oncogenes, are involved in carcinogenesis. Also, in some aspects of tumor progression these genes play a role. Whether or not they also function in the development of invasion and/or the metastastatic phenotype is largely unknown. The family of ras genes, which comprises of $\mathrm{N}-, \mathrm{Ki}-$, and $\mathrm{Ha}-\mathrm{ras}$, is frequently pointmutated in human colorectal carcinomas but their exact role in carcinogenesis and tumor progression is not understood $(3,4)$. In this thesis model studies on the possible role of the pointmutated c-Ha-ras gene in tumor progression in human colorectall carcinoma are reported.

This introductory chapter starts with a brief survey of the characteristics of the invasive and metastatic cell and of the tools to investigate invasion and metastasis. Subsequently, the structure, regulation, and function of the c-Ha-ras protein, the effects of its pointmutated counterpart on cell lines, and the occurrence of pointmutations in the c-ras gene family in colorectal cancer are discussed. The final part of this chapter briefly outlines the aims and strategies of the reported studies.

\subsection{INVASION AND METASTASIS}

\subsubsection{Characteristics of the invasive and metastatic cell}

The development of a metastatic lesion is the terminal stage of a dynamic proces during which a normal cell gradually acquires a phenotype that enables the cell to grow outside its normal microenvironment. The mechanisms behind this conversion have not been fully elucidated yet, but disorders in the control of the cell cycle, leading to genetic instability and genetic abnormalities, appear to be involved in the onset of cancer (5-7). The final steps of carcinogenesis encompass the invasive and metastatic cascade of events.

The metastatic cascade, the dissemination of carcinoma cells from the primary site to distant organs, can be divided in several steps $(8,9)$. First, the epithelial basement membrane, a specialized structure of the extracellular matrix which separates tissue 
compartments, must be traversed (10). Increased proteolytic acticity at the leading edge of invading carcinoma cells might be required at this stage (11). Second, carcinoma cells must detach from the primary tumor, implicating involvement of cell-cell adhesion molecules, which regulate tissue architecture (12). Third, carcinoma cells must express cell adhesion molecules, which are able to interact with extracellular matrix components, in order to migrate through the extracellular matrix (13). Migration of carcinoma cells at this stage might be facilitated by the secretion of autocrine factors that increase cell motility (14-16). Fourth, the carcinoma cell must gain acces to lymphatics or blood vessels for further dissemination, and thereby must be able to penetrate the endothelial basement membrane. Fifth, carcinoma cells have to survive the circulation in order to lodge elsewhere. Sixth, they should again traverse the endothelial basement membrane, migrate through extracellular matrix and grow at ectopic sites in order to develop metastases.

Although every step in the metastatic cascade is essential for a metastatic lesion to develop, tumor cell invasion defined as the ability of a tumor cell to traverse the basement membrane, detach from the primary tumor, and migrate through the extracellular matrix in an abnormal tissue compartment, marks the transition from benign to malignant behavior. For this reason, the molecular mechanisms of basement membrane remodeling by proteases and the interactions of the cell with its microenvironment through cell adhesion molecules will be disscussed briefly. Subsequently, the possible mechanisms which influence the dissemination of carcinoma cells are reviewed.

\section{Proliferation, genetic instability, and tumor cell heterogeneity}

Cell proliferation is required to substitute cells lost either by physiological mechanisms, such as programmed cell death, or by non-physiological mechanisms, such as injury. Physiological cell proliferation is strictly controlled and in balance with cell loss. During DNA replication genetic errors may be introduced intó genomic DNA (17). Increased cell proliferation has been associated with an increased probability of cancer $(6,17-20)$. Because genetic alterations are crucial in carcinogenesis (21) it is conceivable that increased genetic instability due to the introduction of errors in replicated DNA of proliferating cells can contribute to the generation of cancer $(5,7)$. An argument in favor of this mechanism is the recent genetic mapping of a locus, which predisposes to human familial colorectal cancer (22). The presence of widespread alterations in short repeated DNA sequences in these familial colorectal cancers suggested that numerous replication errors were introduced during tumor development. It was therefore postulated that this locus contains a gene involved in DNA replication (23).

Genetic errors occur during the replication of DNA in the S-phase of the cell-cycle and during the chromosomal segregation in the mitosis or M-phase of the cell-cycle (7). Cell-cycle checkpoints ensure that faults in the replication of DNA and in chromosomal segregation are minimalized (7). They do so by functioning as feed-back controls in 
eukaryotic cells. An important cell-cycle checkpoint is the start of the M-phase, which is inhibited if DNA replication in S-phase is not finished yet $(7,24)$. The maturation promoting factor (MPF) is essential in this regulation (7). Inactive MPF, a complex of cyclin $B$ and a tyrosine phosphorylated protein kinase $\mathrm{p} 34^{\text {cac } 2}$, blocks the entry of the cell into the M-phase (7). MPF is maintained in the inactive form by the presence of unreplicated DNA or damaged DNA (7). After completion of the S-phase, tyrosine dephosphorylation activates MPF, which in turn initiates the start of the M-phase, where chromosomes condense and become aligned at the metaphase plane (7). Segregation of the chromosomes proceeds after MPF is inactivated by the degradation of cyclin B, leaving $\mathrm{p} 34^{\text {cde } 2}$ intaet for the next round of cell division (7). Various mechanisms for repair of DNA damage are known, which correct genetic errors occurring during DNA replication or which are induced by non-physiological agents, such as UV-light. Defects in these repair mechanisms increase the number of genetic errors during cell proliferation and make cells susceptible to carcinogenesis $(21,25)$. Indeed, skin cells from Xeroderma pigmentosum patients, which are defective in DNA repair mechanisms, are vulnerable for the development of cancer induced by sun light, most likely because of the accumulation of pyrimidine dimers $(26,27)$. Such skin tumor cells from Xeroderma pigmentosum patients contain twice as many mutated c-ras genes than skin tumor cells from normal patients (28). Furthermore, human colorectal tumors have been shown to harbour mutations in the catalytic domain of DNA polymerase $B$, which is involved in DNA repair (29). The product of the p53 tumor suppressor gene, which is the gene most frequently mutated in human tumors (30), is involved in a mechanism to delay entrance of cycling cells into the M-phase if DNA damage occurs, allowing DNA repair before the cell-cycle progresses (31). Therefore, when the p53 gene harbours a pointmutation, the cell-cycle may progress with unrepaired DNA-lesions, thereby increasing the number of genetic abnormalities. Thus, defects in DNA repair pathways increase genetic instability and may result in the multiple mutations which accumulate during carcinogenesis $(21,25)$.

Given the relation between cell proliferation and carcinogenesis it might not be surprising that a considerable proportion of the known oncogenes are truncated or altered forms of genes, which function in the regulation of cell proliferation. These include growth factors, such as PDGF and CSF-1, and their respective receptors, signal transducing proteins, such as the c-ras genes, and non-receptor tyrosine kinase proteins, such as the src gene family, and transcription factors, such as c-fos (32).

Although it is generally believed that a primary tumor derives from the clonal expansion of one progenitor cell, carcinomas tend to be heterogenous with regard to their genotypical and phenotypical characteristics. It is plausible to assume that continuous proliferation of a progenitor cell with insufficient control of DNA replication and chromosome segregation, increases genetic instability of its offspring. This might be the driving force behind the generation of tumor cell heterogeneity. The ongoing genetic instability may affect the expression of genes or even cause loss of genes. This implies that gene expression in cancer cells is partly autonomous rather than strictly regulated 
by the microenvironment. Especially in the later stages of cancer development, when genetic alterations are frequent, this mechanism might contribute to the autonomous growth of carcinomas.

\section{Proteases}

One of the first obstacles that carcinoma cells encounter is the basement membrane. The epithellal basement membrane consists of a thin sheet of macromolecules (reviewed in $33,34)$. The most prominent components are type IV collagen, which functions as a scaffolding protein, and laminin, adhering to type IV collagen and mediating cell binding (34). Continuous remodeling of the basement membrane is observed in neoplasia, and it has been proposed that imbalance between breakdown and synthesis determines invasive behavior of carcinoma cells (33).

Breakdown of the basement membrane involves degradation of type IV collagen. Metalloproteases have been detected, which degrade type IV collagen, whereas interstitial type I and III collagens are degraded by other metalloproteases $(8$, and references therein). Under physiological conditions the activity of metalloproteases must be controlled tightly to prevent excessive degradation of the extracellular matrix. Tissue inhibiting metalloproteases (TIMP-1 and -2) bind irreversibly to active metalloproteases rendering them inactive $(35,36)$, and may thus be involved in the regulation of collagenolytic activity.

Metalloproteases are found in active and latent forms (8). The latent form of type IV collagen specific metalloproteases can be activated by cleavage via plasmin $(37,38)$. Plasmin is a serine protease and is formed after proteolytic activation of the inactive precursor plasminogen (39), which is able to bind to collagen type IV (39). The activation of plasminogen into plasmin is mediated by plasminogen activators, of which two forms are known, the urokinase-type (u-PA) and the tissue-type (t-PA) (reviewed in 40). Studies indicate that the physiological function of plasminogen activators, and particularly u-PA, involves tissue degradation in the normal organism (40). U-PA is secreted as an inactive, single chain $55 \mathrm{kDa}$ protein (41), and is activated after cleavage at position 157 into a two chain (A and B) molecule (42). A high affinity receptor for U-PA has been reported, which binds the $A$ chain so as to orient the $B$ chain with proteolytic activity toward its target plasminogen (43), converting it into plasmin (44). In this way, catalytic activity is confined to a small region at the cellular surface, which allows local breakdown of the basement membrane.

Active $\mathrm{U}-\mathrm{PA}$ is rendered inactive after binding to plasminogen activator inhibitors (PAl's), of which two forms are known (45). If active U-PA is attached to the U-PA receptor (u-PAR) and PAl-1 binds to u-PA, then the whole complex is internalized (46, 47 ), a process mediated by the low density lipoprotein receptor-related protein (LRP) (48). The u-PA-PAI-1 complex is degraded in the lysosomes and the u-PA receptor recycles back to the cell surface (48).

Collectively these proteins allow controlled degradation of the basement membrane in the following way. Degradation is initiated by the secretion of u-PA. After binding of 
active U-PA to u-PAR, plasminogen is converted into plasmin. In turn, plasmin mediates the conversion of the latent form of type IV collagenase into the active form. Proteolytic activity is terminated after the binding of either TIMP-1 to type IV collagenase or PAI-1 to u-PA. Another round of the proteolytic cascade may start when the recycled $u-P A$ receptor again binds $u-P A$. The presence of PAI-1 (49) and most likely TIMP-1 $(50,51)$ in the extracellular matrix might prevent excessive degradation of the basement membrane.

The ability of carcinoma cells to traverse the basement membrane and leave the compartment to which they are normally confined implies that a local imbalance between membrane degradation and synthesis occurs. Indeed, invasive and metastatic behavior has been correlated repeatedly with increased expression of u-PA (52-59) and type IV collagenase (60-62). Further, increased numbers of u-PAR saturated with u-PA positively correlated with invasive $(63,64)$ and metastatic capacity $(65)$. This latter mechanism might contribute also to the induction of tissue invasiveness by macrophage colony-stimulating factor (CSF-1), in CSF-1-receptor positive carcinoma cells $(66,67)$. Inhibition at each step in the proteolytic cascade reduces the invasive potential of tumor cells (68-70) and expression of TIMP-1 is inversely correlated with invasive and/or metastatic behavior of tumor cells $(36,71)$.

The expression of several components in the proteolytic cascade has been investigated in colon cancer. It was found that mRNA encoding for type IV collagenases (72 and 92 $\mathrm{kDa}$ ) is expressed in fibroblasts and tissue macrophages in stroma surrounding invasive cancer tissue, but not by carcinoma cells (72). U-PA mRNA and U-PAR mRNA has been detected in fibroblast-like stromal cells and in carcinoma cells at invasive foci of human colon adenocarcinomas (73). However, u-PA has been demonstrated histochemically in the cytoplasm of neoplastic columnar epithelial cells in carcinomas and adenomas of the colorectum (74). Both studies reported absence or low expression of u-PA in normal colonic tissue. Expression of PAI-1 mRNA was noted in endothelial cells in the stroma surrounding invasive tumor glands in colon adenocarcinomas (75). These results indicate that the components of the proteolytic cascade are in close proximity of each other at the invasive edges of human adenocarcinoma of the colon. This suggests a role for the u-PA induced proteolytic activity in invasion of carcinoma cells. However, the interactions between the participating cells and proteins are not yet clear, though an excess of u-PA over PAl and the concentration of u-PA proteolytic activity by U-PAR to a small area of the cell surface may contribute to tumor progression in the colon $(63,64,76,77)$.

\section{Cell adhesion molecules}

In the interactions between carcinoma cells and their microenvironment cell adhesion molecules play a prominent role. Detachment of a carcinoma cell from the primary tumor mass most likely involves a particular class of cell-cell adhesion molecules, the cadherins $(13,78)$. In the migration of a carcinoma cell through the extracellular matrix 
a prominent role is probably played by integrins, more specifically the tamily of $B_{1}$ integrins, a family of cell-extracellular matrix adhesion molecules (13).

\section{Cadherins.}

The interactions between epithelial cells in a parenchymatous organ are mediated by cadherins, transmembrane calcium dependent cell-cell adhesion molecules. Cadherins show homophilic interactions: they bind selectively to identical cadherin molecules. For example, E-cadherin binds only to E-cadherin. This might provide a mechanism for the preferential adhesion between homotypic cells and implies an important role for cadherins in maintaining tissue integrity (12).

The family of cadherins as yet comprises four members: $E_{-}, P_{-}, N_{-}$, and R-cadherin (12). The extracellular domain of cadherins is responsible for homophilic binding (79). The intracellular domain is the most conserved region in the cadherin family, which implies an important function for this domain. Deletion of this domain, even while the extracellular domain is intact, abrogates the function of cadherin as cell-cell adhesion receptor $(12,80,81)$.

Cadherins are concentrated at special zones in the plasma membrane, the adhesion belts, where the intracellular domain interacts with the cytoplasmic proteins $\alpha-\beta$, and $\gamma$ catenins $(12,81)$. The catenin-associated form of E-cadherin can bind to actin. This association is most likely a prerequisite for the function of cadherins (81) and might include a morphoregulatory role. This is suggested by the following observations. Monoclonal antibodies specific for E-Cadherin disperse cel! monolayers (82) and cells lacking $\alpha$-catenin grow as isolated cells, but after transfection with $\alpha \mathrm{N}$-catenin cDNA cellular aggregates are formed (83). In both cases the morphology of the cells changes. Morphological changes parallelling invasive behavior of carcinoma cells have been demonstrated after loss of E-cadherin mediated cell-cell adhesion (82). Re-expression of E-cadherin inhibited invasive behavior (84).

Alteration of cell morphology most likely results from rearrangements in the actin cytoskeleton. Actin filament bundles are attached to adhesion belts by the proteins vinculin and $\alpha$-actinin (85). Proteins of the src proto-oncogene family, src yes, and $b y$ are concentrated also in adhesion belts (12). These membrane proteins are tyrosine kinases and might regulate the function of the cadherin-cytoskeleton complex or mediate transmission of intercellular signals at adhesion belts. The suggestion that the acquisition of invasive potential involves increased phosphorylation of E-cadherinassociated B-catenin by src (86) lends support to this postulation.

In cancer tissue, the loss of E-cadherin expression is correlated with tumor progression in human breast carcinoma and squamous cell carcinoma of head and neck $(87,88)$, human high-grade prostate and rat prostate cancer $(89,90)$, and mouse squamous cell carcinomas of the skin (91), but is less obvious in human carcinomas of the colon and the lung (92-94).

Thus, although in experimental systems cadherins appear to be involved in carcinoma cell invasion and therefore in tumor progression. Such a relation, however, is less clear in human colorectal cancer tissue. 


\section{Integrins.}

Major components of the extracellular matrix, such as collagen, laminin and fibronectin, are recognized by cells through specific receptors, which belong to a versatile class of heterotypic cell adhesion molecules, the integrins $(78,95,96)$. Integrins are heterodimers of noncovalently associated $\alpha$ and $B$ subunits (96), and especially the subclass of integrins with $B$ subunits are involved in cell-extracellular matrix interactions (78). Most individual integrins bind to more than one ligand and individual ligands in general are mostly recognized by more than one integrin species. The specificity of an integrin further depends on the cell type, e.g. the $\alpha_{2} \beta_{1}$ integrin on platelets is specific for collagen and not for laminin, whereas when present on other cell types it can recognize both ligands. "These modifications make the pattern of interactions between integrins and their ligands rather complicated (96).

Both subunits of most $B_{1}$ integrins are transmembrane glycoproteins with a short cytoplasmic domain and a single hydrophobic transmembrane segment (96). The extracellular domains of both subunits are involved in the recognition of specific amino acid sequences in their ligands, for example the Arg-Gly-Asp (RGD) sequence in fibronectin for $\alpha_{5} \beta_{1}$ integrin and Asp-Gly-Glu-Ala (DGEA) in type I collagen for $\alpha_{2} B_{1}$ integrin (96). Peptides containing these sequences have the ability to inhibit cell adhesion of integrins to certain of these extracellular matrix proteins (78). The cytoplasmic domain of the $B_{1}$ subunit is most likely associated with the cytoskeleton via talin and $\alpha$-actinin $(85,96,97)$. In contrast, the cytoplasmic domain of the $\alpha$ subunit does probably not interact with the cytoskeleton. The different $\alpha$ subunits instead may serve to mediate the different responses of cells to common extracellular ligands (96). This possibility is supported by the fact that chimeric integrin $\alpha$ subunits with different cytoplasmic domains but similar extracellular domains triggered either collagen gel contraction or increased the migratory behavior of cells on a collagen substratum after transfection $(98,99)$.

The effects of extracellular matrix proteins on the behavior of tumor cells are mediated by $B_{1}$ integrins and include induction of collagenase expression, differentiation, and proliferation (100-105). However, $B_{1}$ integrins lack the characteristics one would expect to find in a signal-generating receptor, such as kinase- or phosphatase-domains or sequences suitable for interactions with G-proteins (106-108). Therefore, other mechanisms must be involved. It has been suggested that signal transduction by integrins may be proceded by cytoskeleton rearrangements, thus regulating the cell shape and the biosynthetic capacity of cells, which may contribute to cell growth and differentiation (109 and references therein). Alternatively, enhanced tyrosine phosphorylation of a complex of proteins of $\approx 120-130 \mathrm{kDa}$ is observed after clustering of integtin receptors, which occurs during the formation of adhesive contacts on a substratum $(46,110)$. One of these proteins, a $125 \mathrm{kDa}$ protein, was identified as a substrate for the src family of tyrosine kinases $(111,112)$ and also accumulates in focal adhesive contacts of cells, allowed to spread on fibronectin (113). It turned out to be a novel tyrosine kinase, activated upon phosphorylation, and was named "pp125 Focal 
Adhesion Kinase" or pp $125^{\text {fal }}$ (113). Thus, integrin mediated signal transduction might involve phosphorylation of $\mathrm{pp} 125^{\text {rak }}$ by $s \mathrm{sc}$, which may complentent rather than exclude signal transduction by cytoskeleton reartangements (109).

The expression of $B$, integrins in normal human colon tissue was readily demonstrated for $\alpha_{1}, \alpha_{2}, \alpha_{3}$ and $\alpha_{6}$ integrins (114-117). The laminin receptor $\alpha_{6} B_{1}$ was found on the basal plane of epithelial cells, facing the basement membrane (117). The integrin receptors for collagen $\left(\alpha_{2} \beta_{1}\right)$ and both collagen and laminin $\left(\alpha_{3} \beta_{1}\right)$ were found at the basolateral surface (117), in agreement with their putative function as homophilic intercellular receptors $(118,119)$. Downregulation of the $B_{1}$ integrins $\alpha_{2}$ and $\alpha_{3}$ is generally observed in colon carcinomas $(78,115,120,121)$ and is associated with poor differentiation $(102,120)$. The $\alpha_{6} \beta_{1}$ integrin is expressed in colonic adenomas as well as in carcinomas (115), though in general downregulation is observed in carcinomas (117). Thus, decreased expression of a subset of integrins goes along with invasive properties of colorectal carcinoma cells.

Experimental systems also support a role for several $B_{1}$ integrins in invasion and metastasis. RGD-containing peptides injected simultaneously with metastatic B16-F10 murine melanoma cells in the tail vein of mice markedly reduced the number of lung metastases (122). Increased expression of $\alpha_{2} \beta_{1}$ integrin in rat rhabdomyosarcoma cells augmented metastatic behavior (123) and increased expression of $\alpha_{6} \beta_{1}$ and $\alpha_{2} \beta_{1}$ integrins in chemically transformed human osteosarcoma cells was associated with increased tumorigenic potential (124), whilst increased levels of $\alpha_{5} \beta_{1}$ integrin correlated with decreased tumorigenicity in chinese hamster ovary cells (125).

Apparently, the cell type involved in these studies, the stage at which the metastatic cascade was investigated, and the experimental method which was applied, may influence the results. However, it has been suggested that in the early stages of tumor growth, decreased adhesion to extracellular matrix proteins by downregulation of integrin expression is favored, in contrast to later steps in the metastatic cascade, when lodging of carcinoma cells might profit from increased expression of integrins (78).

\section{Dissemination of carcinoma cells}

The pattern of metastatic spread of carcinoma cells is currently regarded to be determined by mechanical factors and by site-specific interactions of carcinoma cells with organ tissue (reviewed in 126).

Site-specific interactions may contribute to the preference of e.g. prostatic carcinoma cells to metastasize to bone tissue (126). Several mechanisms may contribute to sitespecific metastasis. The presence of specific growth stimulating conditions in the target organ may promote cell-division of carcinoma cells (127). Organ-specific adhesion molecules on vascular endothelium may interact with adhesion molecules expressed by the carcinoma cell. The different constitution of the extracellular matrix in various organs (128) may inhibit invasion of carcinoma cells, unless they express specific proteolytic enzymes (126). 
The mechanical theory considers the various tissues to be passive receptacles for carcinoma cells. The first organ encountered after shedding in the venous circulation would arrest the greatest number of carcinoma cells, and consequently, be the organ with the highest number of metastatic colonies. This would for instance explain the colonization of the liver by colorectal cancer (126).

Mast likely, both mechanisms complement each other (126).

\subsubsection{Tools to investigate invasion and metastasis}

In the preceding paragraphs it was outlined that colorectal carcinoma cells are able to 1) traverse the basement membrane, 2) migrate through the extracellular matrix, 3) enter and survive the circulation, 4) lodge elsewhere in the circulation and extravasate, and 5) resume growth at a distant site forming a metastasic lesion. This complexity of the metastatic cascade makes it necessary to investigate the separate steps in different in vitro and in vivo models with various techniques. A brief description is presented of models and methods, which have been used in our studies.

\section{Patient material}

An important source of information, concerning the role of specific proteins in tumor progression, comes from patient material, which is also used to validate concepts developed in basic research. Tissue sections can be used to perform immunohistochemical or in situ hybridization studies and fresh tumor material to analyze the expression of genes at the protein- and mRNA-level and to detect mutations at the DNA-level. With knowledge of these parameters it can be investigated whether specific patterns of expression or mutations are correlated with survival of the patient, recurrence after resection, or the chance of development of distant metastatic lesions.

\section{Cell lines}

Tumor cells, isolated from either a primary tumor or a metastatic lesion, can be cultured in vitro and may yield a permanent cell line. The relative ease of handling cell lines makes them suitable for use in in vitro and in vivo model systems. However, for most tumor types a subset of around 30\% of the primary tumors can be succesfully cultured in vitro (129). This approach may therefore not be representative for all tumors. Furthermore, cell monolayers constitute a two-dimensional model system, which does not resemble the three-dimensional in vivo situation.

Nonetheless, cell lines are highly amenable to genetic modification. The introduction of exogenous genes by various transfection methods can be used to establish a putative role for the transfected gene by investigating cell behavior after transfection in various assays. However, the different techniques for transfection and the different plasmid constructs together with the lack of standard protocols and the fact that each transfectant is unique with respect to the site of integration, may complicate comparison of transfection experiments. This may be the cause of conflicting results with regard to the function of transfected genes (130). 


\section{In vitro models}

The first two steps of the metastatic cascade can be studied with a variety of in vitro models (131). The effects of proteolytic activity can be studied by analyzing the degradation of reconstituted basement membranes by cancer cells (131). Attachment assays to various components of the extracellular matrix measure the potential of the carcinoma cell to interact with the extracellular matrix. The invasion of carcinoma cells into collagen gels measures invasive potential (132). Most models constitute twodimensional systems. In contrast, the confrontation of tumor cells witli embryonic chick heart fragments is a three-dimensional model (133) and mimicks the in vivo situation more closely than two-dimensional models do. It is amenable to in vitro manipulation, thus providing a suitable model for the study of the first two steps in the metastatic cascade $(84,133)$.

\section{In vivo models}

Later steps in the metastatic cascade, such as survival and lodging elsewhere in the circulation, can be studied more appropriately in in vivo models. Prominent models are injection of tumor cells into the chorioallantoic membrane veins of chick embryos (134), and injection of tumor cells at various sites in nu/nu mice $(135,136)$. Immunodeficient chick embryos and athymic T-cell deficient nu/nu mice allow growth of human cancer cells and therefore are suited to study metastasis formation $(134,135)$. The capacity of cancer cells to survive in the circulation and their ability to lodge elsewhere, can be assessed by measuring the lung colonization potential of cancer cells after injection in the tail vein of nu/nu mice, known as the experimental metastasis assay. Injection of cancer cells in the subcutis is relatively easy, results in most cases in solid tumor growth and is applied to measure the tumorigenic potential of cancer cells. However, spontaneous metastases in this model are rare with the exception of melanoma xenografts (135). Metastasis formation is increased when tumor cells are injected orthotopically, which for colorectal cancer cells implies that they are injected in the cecum. Orthotopic xenografting allows the study of the entire metastatic cascade (136).

\subsection{THE C-HA-RAS ONCOGENE}

\subsubsection{Structure, function, and expression of the c-Ha-ras protein}

Structure. The $\mathrm{N}$-, Ki- and Ha-ras genes encode similar proteins of $21 \mathrm{kDa}$, structurally homologous with the $\alpha$-subunit of heterotrimeric $\alpha \beta y$ G-proteins, which function in signal transduction (137). The $\alpha$-subunit of a G-protein has intrinsic GTPase activity. By binding GTP, the G-protein is activated, deactivation follows through hydrolysis of GTP into GDP, which is regulated by the intrinsic GTPase activity. The activity of the p $21^{\text {ras }}$ proteins is regulated similarly (Fig. 1), but their rate of GTP hydrolysis is two orders of magnitude lower than that of G-proteins (138). 


\section{Transient}

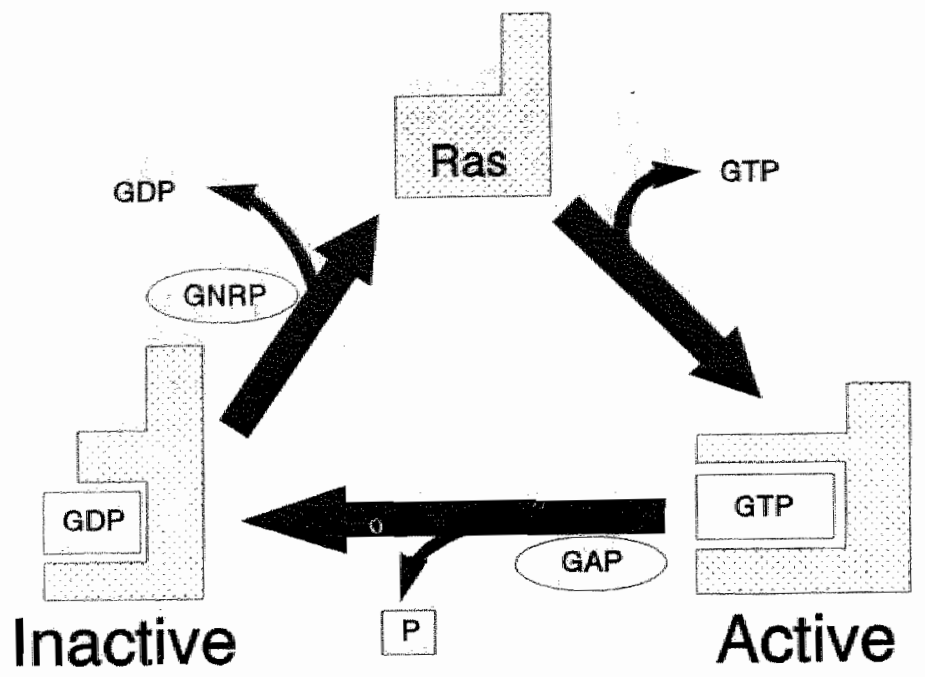

Figure 1. Schematic representation of the regulation of $p 21^{\text {ras }}$ protein activity.

GAP increases the intrinsic GTPase activity of $2^{2} t^{\text {rat }}$ protens. GNRP increases the exchange rate of guanine nucleotides bound to $\left.\mathrm{p} 2\right|^{\text {ras }}$ proteins.

The $\mathrm{p} 21^{\text {ras }}$ proteins from different organisms contain several highly conserved regions, which appear to be essential for their normal function. These regions are involved in the binding of GTP and GDP, in the hydrolysis of GTP into GDP, in the attachment to the plasma membrane, and in the biological activity of the $221^{\text {ras }}$ proteins $(139,140)$. The guanine base of GTP and GDP is bound with high specificity in a "deep narrow groove" which is formed by the amino acid residues $116-119$ and $145-147(139,141)$. The B- and $\gamma$-phosphates of GDP and GTP interact with a $\mathrm{Mg}^{2+}$ ion and form hydrogen bonds with amino acid residues 13-17, 32, 35, 60, 172-175 and 189. The many interactions explain the high affinity of $\mathrm{p} 21^{\text {ras }}$ proteins for GDP and GTP. The paucity of interactions with the $\alpha$-phosphate most likely explains the low affinity of p2 $1^{\text {ras }}$ proteins for GMP $(139,142)$. The catalytic mechanism of the hydrolysis of GTP to GDP involves the $\mathrm{Mg}^{2+}$ ion and the amino acid residues 35 and 53-61 (138, 139), but the exact mechanism has not yet been elucidated (143).

In the C-terminus the amino acid residues $165-185$ compose the region with the least similarity between $\mathrm{N}-$, Ki- and Ha-ras proteins (144-147). The four C-terminal residues 186-189, however, are conserved in all $\mathrm{p} 2 \mathrm{I}^{\mathrm{ras}}$ proteins and contain a CAAX-box, where $\mathrm{C}$ is cysteine, $\mathrm{A}$ is any aliphatic amino acid and $\mathrm{X}$ is any amino acid. CAAX is a signal sequence for postranslational modification and ensures translocation of cytosolic $\mathrm{p} 21^{\text {ras }}$ proteins to the plasma membrane, after the subsequent action of farnesyl transferase, 
protease and methyl transferase (139). A basic region of six lysine residues in the $\mathrm{C}$ terminus of the Ki-ras protein, together with farnesylation, allows firm anchoring of the c-Ki-ras protein to the inner side of the plasma membrane (148). The $\mathrm{N}$ - and Ha-ras proteins, however, lack these lysine residues in the C-terminus, but contain one or two cysteine residues, which need to be palmitoylated before firm anchoring in the plasma membrane is achieved (148). It has been suggested that the variation in membrane anchoring might target different ras proteins to specific sites in the plasma membrane. Whether or not this has functional consequences $(139,146)$ remains to be determined. The biological activity of the $\mathrm{p} 2 \mathrm{1}^{\mathrm{ras}}$ proteins is mediated by the amino acid residues 32 40 , the so-called "effector region", which is exposed on the surface of the molecule. The structural difference between GDP- and GTP-bound states is most marked in this region, in particular the amino acid residue 35 (139). However, the conformational changes in amino acid residues 60-63 also differ dramatically between GTP- and GDPbound forms of $\mathrm{p}^{2} \mathrm{I}^{\mathrm{ras}}$ proteins, and therefore this domain might also have a role in the biological activity (138). Furthermore, the amino acid residues 26, 27, 30, 31, 45, flanking the effector region, seem to be required also for normal protein-protein interaction and biological activity (149).

Function. The p $21^{\text {ras }}$ proteins have different functions in different organisms (150). The p2 $1^{\text {ras }}$ homolog, ste5, in $S$. Pombe is involved in mating (151) and the $221^{\text {ras }}$ homolog, RAS1, in S. Cerevisae stimulates adenylate cyclase, which leads to proliferation (150). The $\mathrm{p} 21^{\text {ras }}$ proteins function in other cell systems at crucial points in the pathway towards cellular differentiation. The $\mathrm{p} 21^{\text {ras }}$ homolog, let-60, in C. elegans is needed in the signal transduction pathway, by which epidermal precursor cells are activated to differentiate into mature vulva cells $(152,153)$ and a similar role is observed in eye development of Drosophila melanogaster, where the precursor cell of the R7 photoreceptor cell requires increased activity of the Ras 1 protein in order to differentiate into neuronal cells instead of nonneuronal cone cells (154-156). Thus, $\mathrm{p} 21^{\text {ras }}$ proteins function in pathways leading to proliferation as well as to differentiation; depending on the cell system.

The similarity of $\mathrm{p} 21^{\text {ras }}$ proteins with G-proteins suggests that they play a role in at second messenger system. In mammalian cells, the phosphoinositide second messenger system has been implicated in signal transduction by $21^{\text {tas }}$ proteins. Especially the roles of phospholipase C (PLC) and protein kinase C (PKC) have been investigated, but a coherent picture has not emerged yet (reviewed in 139).

Expression. In most human tissues expression has been observed of $\mathrm{p}^{\circ} 1^{\text {ras }}$ proteins ( 157. 158). The level of expression varies among different cell types, e.g. melanocytes lack expression of $\mathrm{p} 21^{\text {ras }}$ completely, whereas endocrine cells in the pancreas and thyroid express $p 21^{\text {ras }}$ proteins abundantly. Expression in fetal tissue matches with expression in adult tissue, though not completely. E.g. specialized cells from the nervous systen stain strongly for $\mathrm{p} 21^{\text {ras }}$ protein in fetal and adult tissue, whereas in the lymphoid system high expression is observed in the fetal thymus, but not in adult lymph nodes. 
Immunohistochemical studies of mature collon tissue demonstrate that $\mathrm{p} 21^{\text {ras }}$ proteins are expressed in the basal cells of the crypts, which have proliferative capacity (158). Immunoreactivity decreases towards the lumen, but strong immunoreactivity is again detected in the apical brush border of the highly differentiated cells lining the lumen of the intestine (158). A major limitation of these immunohistochemical studies has been the use of monoclonal antibodies (e.g. Y13-259) which recognize both normal and pointmutated forms of the $\mathrm{c}-\mathrm{N}-$-, c-Ki- and $\mathrm{c}-\mathrm{Ha}-\mathrm{ras}$ proteins. Therefore, which of the p2 $I^{\text {rag }}$ proteins are expressed exactly, cannot be determined $(157,158)$. In homogenates of normal colorectal tissue expression of both $\mathrm{c}-\mathrm{Ki}$ - and $\mathrm{c}$-Ha-ras genes have been detected. The expression of the $\mathrm{c}-\mathrm{N}$-ras gene was not investigated in these studies (159, 160). A limitation of the latter studies is the fact that in tissue homogenates the individual contribution of different cell types to the total expression of the c-ras genes cannot be determined. Nevertheless, the high level of expression of $\mathrm{p} 2 \mathrm{I}^{\mathrm{ras}}$ proteins in cells with proliferative capacity as well as in fully differentiated cells might indicate that $\mathrm{p} 21^{\text {ras }}$ proteins fullfill functions in regulating cell proliferation as well as specialized cell functions (158).

\subsubsection{Regulation of the c-Ha-ras protein activity}

The high affinity for GTP and GDP along with the low intrinsic dissociation constant and GTPase activity of $\mathrm{p} 21^{\text {ras }}$ proteins allows precise control of $\mathrm{p} 21^{\text {ras }}$ activity by regulatory proteins $(138,150)$, which either increase the rate of exchange of GDP for GTP or alter the intrinsic GTPase activity of $\mathrm{p}^{2} 1^{\text {ras }}$ proteins (Fig. 1) $(138,150)$.

Proteins which increase the rate of nucleotide exchange are termed Guanine Nucleotide Releasing Proteins or GNRP's and have been isolated by several groups from cytosolic pools of mammalian cells (161-163). Normally, p2 $11^{\text {ras }}$ proteins are found in the inactive GDP-bound form (150). About $95 \%$ of the cytosolic guanine nucleotide pool consists of GTP. The binding of $\mathrm{p} 2 \mathrm{l}^{\mathrm{ras}}$ with a GNRP promotes GDP release, thus most likely results in the replacement of GDP by GTP, thereby activating $\mathrm{p} 2 \mathrm{I}^{\text {ras }}$ proteins (150).

Two proteins (GAP and NF-1) are known to increase the intrinsic GTPase activity of p $21^{\text {ras }}$ proteins and are termed GTPase Activating Proteins or GAP's, which are found in the cytoplasm $(139,164-166)$. GAP's convert the active GTP.p2 $]^{\text {ras }}$ complex into the inactive GDP-bound form of $\mathrm{p} 21^{\text {ras }}$, thus down-regulating $\mathrm{p} 21^{\text {ras }}$ protein activity (139). GAP and NF-1 interact with GTP.p $2 I^{\text {ras }}$ proteins at the effector region $(167,168)$ This region is essential for the biological activity of GTP.p2 $1^{\text {mas }}$ and it therefore leaves open the possibility that GAP and NF-1 are not only down-regulators, but possibly also effectors of GTP.p2 $11^{\text {ras }}$ proteins (168).

The primary structure of GAP has been determined (Fig. 2) (169). The N-terminus is highly hydrophobic and followed by a proline-rich sequence, possibly indicating a flexible hinge region. Adjacent to the hydrophobic domain are regions similar to a module of 100 and a module of 50 amino acid residues of the proto-oncogene src, the so-called Sre Homology domain 2 (SH2) and Src Homology domain 3 (SH3) respectively. $\mathrm{SH} 2$ and $\mathrm{SH} 3$ domains are found in several cytoplasmic signaling proteins 
and function as adapter modules (170), coupling receptor tyrosine kinases with their down-stream targets (171-177). The C-terminal part of GAP is the binding site for GTP.p2 $1^{\text {ras }}$ and contains the GTPase stimulating activity (169). The activity of GAP is inhibited by some lipids, which function as second messengers in the phosphoinositide pathway $(178,179)$, such as arachidonic acid (180). The putative role for GAP as a target for GTP. $21^{\text {ras }}$ is supported by the fact that the biological effects of GTP.p $21^{\text {ras }}$ require the SH2/SH3 domains of GAP $(181-184)$. NF-1 is similar to GAP with regard to the GTPase activating sequence but lacks the SH2/SH3 domains (168). It seems to be that NF-1 is not required for the biological effects of $221^{\text {mas }}$ proteins, which makes it unlikely that NF-1 functions as a downstream effector of GTP.p21 $1^{\text {ras }}$ (185). Possibly, NF-1 acts as a constitutive downregulator of GTP.p2 $1^{\text {ras }}$ (186), whereas GAP is involved in downstream signaling of GTP.p2 $1^{\text {ras }}$ (187).

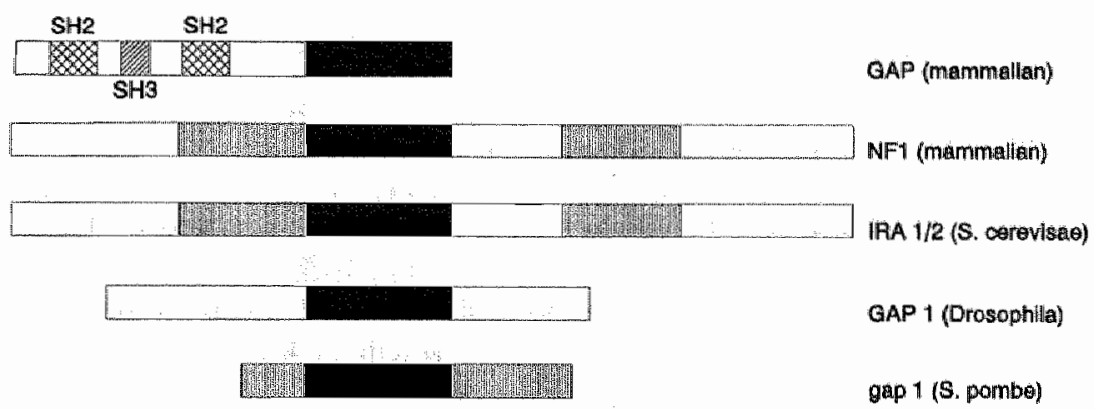

Figure 2. Structural resemblance of GAP and GAP-related proteins.

The black box contains the $221^{\text {ras }}$ binding domain and the GTPase activating domain, the shaded box contains a domain with a high degree of similarity in all GAP-related proteins (modified from ref. 168).

As yet, one protein has been isolated which inhibits the intrinsic GTPase activity of GTP.p2 $\mathrm{I}^{\text {ras }}$ proteins. This protein can interact directly with $\mathrm{p} 2 \mathrm{l}^{\text {ras }}$ proteins but the mechanism of inhibition is not known (179). Its activity is increased by phospholipids from the phosphoinositide pathway (179). The dual effect of these lipids, which activate GTPase inhibiting protein and inactivate GAP, tends to increase the biological activity of $\mathrm{p} 21^{\text {ras }}$ proteins and thus stimulates cell proliferation (179).

Similar regulatory proteins are also found in other organisms $(139,150)$, indicating that the control of $\mathrm{p} 2 \|^{\text {tas }}$ activity is conserved and important for proper functioning of cells. Homologs of GNRP's are ste6 in $S$. pambe (188), CDC25 in $S$. cerevisae (189), and Son of sevenless in Drosophila $(154,190)$. Homologs of mammalian GAP are the gap/sarl gene in S. pombe $(191,192)$, the IRA1 and IRA2 genes in S. cerevisae (150), and GAP1 in Drosophila (193). 


\subsubsection{Growth Factors and $\mathrm{p}^{\text {ras }}$ proteins in signal transduction pathways}

Increased cell proliferation is a crucial element in carcinogenesis $(6,17)$. Knowledge about the function of the $\mathrm{p} 2 \mathrm{l}^{\text {ras }}$ proteins in the mitogenic signal transduction pathway may elucidate the role of pointmutated $\mathrm{p} 2 \mathrm{1}^{\mathrm{ras}}$ proteins in carcinogenesis.

Growth factors, such as the epidermal growth factor (EGF), the platelet derived growth factor (PDGF), or CSF-1, induce transcription of genes and elicit a mitogenic response in receptor positive cells (194). Increased levels of the active GTP.p2 $1^{\text {ras }}$ complex, sufficiently high to support mitogenic stimullation (195), are found in EGF- and PDGFstimulated cells $(196, \cdots 197)$. This suggests a role for $\mathrm{p} 21^{\text {ras }}$ proteins in the signal transduction pathway of Growth Factors, which is supported also by the observation that GAP binds specifically to ligand-activated CSF-1-, EGF- and PDGF-receptors (198-202).

The first event in the signal transduction pathway is ligand-activation of EGF- or PDGF-receptors. The activated receptors dimerize and cross-phosphorylate on cytoplasmic tyrosine residues, which increases their kinase activity toward other substrates $(106,203)$. Substrates for the receptor tyrosine kinases attach to the phosphorylated tyrosine residues by means of their SH2 domain(s) (172). Several substrates, including phospholipase $\mathrm{C}-\gamma \mathbb{1}$ (PLC- $\gamma 1)$ and GAP, bind to the PDGF-receptor but at different phosphorylated tyrosine residues $(201,204,205)$.

In unstimulated cells the level of GTP.p $21^{\text {ras }}$ might be downregulated by NF1, which is supported by the observation that lack of functional NF-1 in cells from neurofibromatosis type 1 patients goes along with increased levels of GTP.p2 $1^{\text {ras }}$ in the presence of functional wild type GAP (206). In growth factor stimulated cells GAP is translocated from the cytosol to the plasma membrane upon binding to ligand-activated growth factor receptors $(201,205)$ and GNRP activity is stimulated, which increases the level of GTP.p2 I ras (Fig. 3) (207, 208). Lipids, generated by activated tyrosine kinase receptor-bound PLC- $\gamma 1$, may inhibit the GTPase activity of GAP but do not interfere with the binding of GAP to the effector region of GTP.p2 $1^{\text {ras }}$. This GTP.p2 $1^{\text {ras }}$ GAP complex has been postulated to expose the SH2 and SH3 domains of GAP, which are normally hidden (Fig. 4) (184). Two tyrosine phosphorylated proteins, p62 and p190, associate with GAP in mitogenically stimulated cells (209). P62 encodes a putative heterogenous muclear ribonucleoprotein particle, which belongs to a family of proteins involved in mRNA processing (210). P190 encodes a remarkable combination of a GTPase like protein at the N-terminus, a GAP like protein at the C-terminus, and in between a protein highly similar to a transcriptional repressor of the glucocorticoid receptor gene (211). P62 and p190, might thus provide a link between growth factors and transcriptional control of genes, mediated by the GTP.p $21^{\text {ras }}$ GAP complex. Termination of the mitogenic stimulus decreases the generation of lipids, restores the GTPase activity of GAP, and inactivates GTP.p $21^{\text {ras }}$ to GDP.p2 $1^{\text {ras }}$. In this model GAP acts both as effector and as negative regulator of GTP.p $21^{\text {ras }}$. 

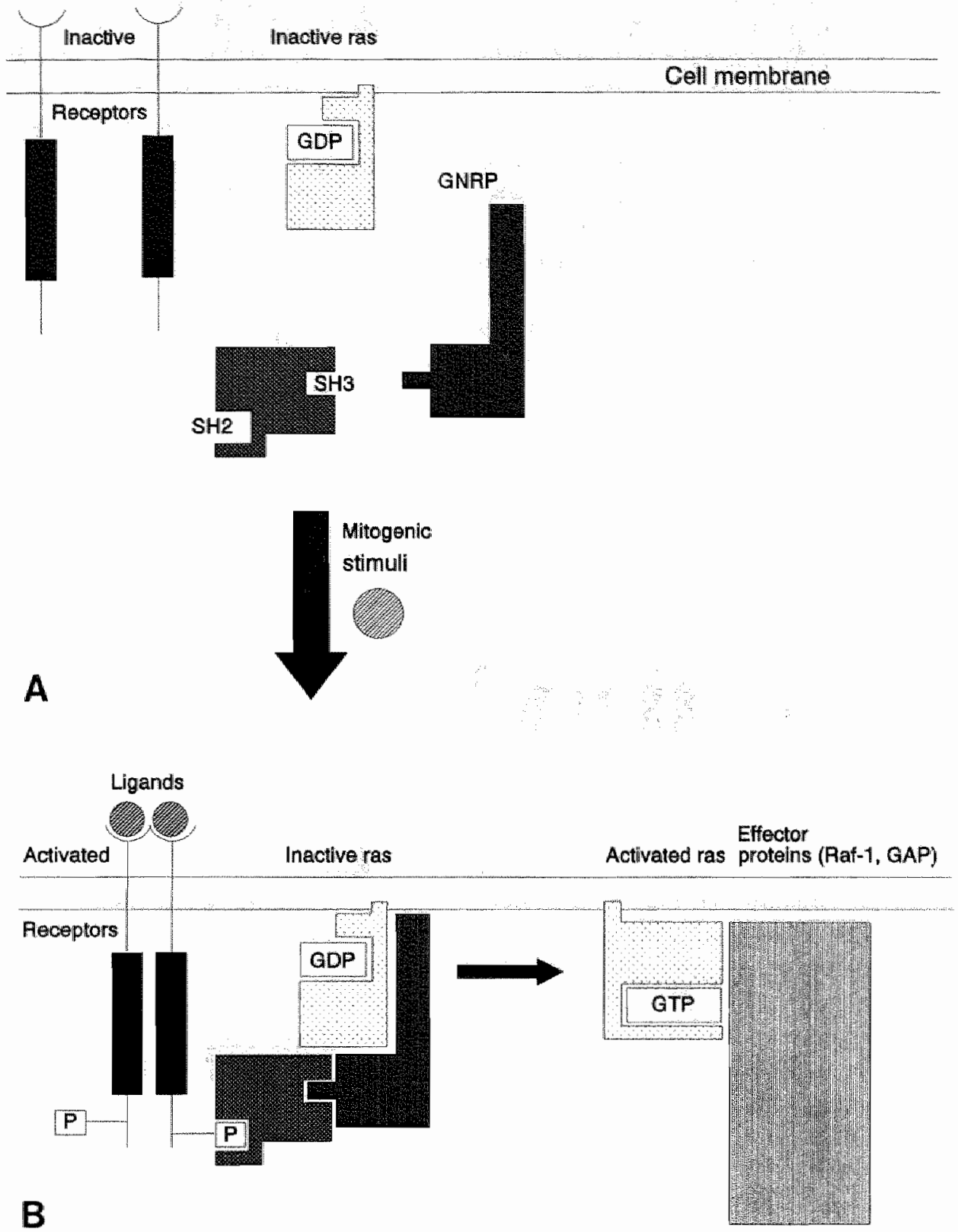

Figure 3. Coupling of $\mathrm{p} 21^{\text {ras }}$ proteins to receptor protein tyrosine kinases.

A. Unstimulated cells. B. Stimulated cells. Proteins with $\$ \mathrm{H} 2 / \mathrm{SH} 3$ domains function as adapter proteins and link receptor protein tyrosine kinases with GNRPs. 
A second signal transduction pathway, which links growth factors and gene transcription via $21^{\text {rats }}$ proteins, involves Mitogen-Activated Protein Kinases (MAPKs). These are serine/threonine protein kinases (212), which are activated during mitogenic stimulation of cells by several growth factors (213) and most likely have a role in the regulation of gene transcription factors (reviewed in 214), such as c-myc $(215,216)$. Activation of MAPKs is controlled by another serine/threonine protein kinase, the proto-oncogene cRaf-1 $(217,218)$. It has recently been demonstrated that $c-$ Raf- 1 interacts directly with GTP.p21 $1^{\text {ras }}$ but not with GDP.p2 $\mathrm{I}^{\text {pas }}$, most likely at the effector region of the $\mathrm{p} 21^{\text {ras }}$ protein. It was therefore postulated that c-Raf-I might be a direct effector of the active p2 $1^{\text {ras }}$ protein (219-221).

Considering the pleiotropic functions of the $\mathrm{p} 21^{\text {ras }}$ proteins, it is reasonable to assume that more signal transduction pathways will be elucidated in which $221^{\text {ras }}$ proteins play a prominent role.
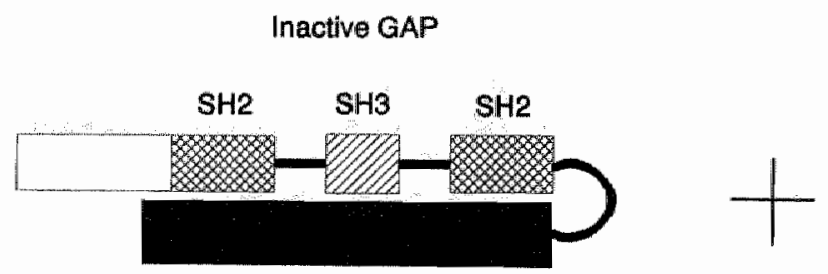

Activated ras

Ras binding domain

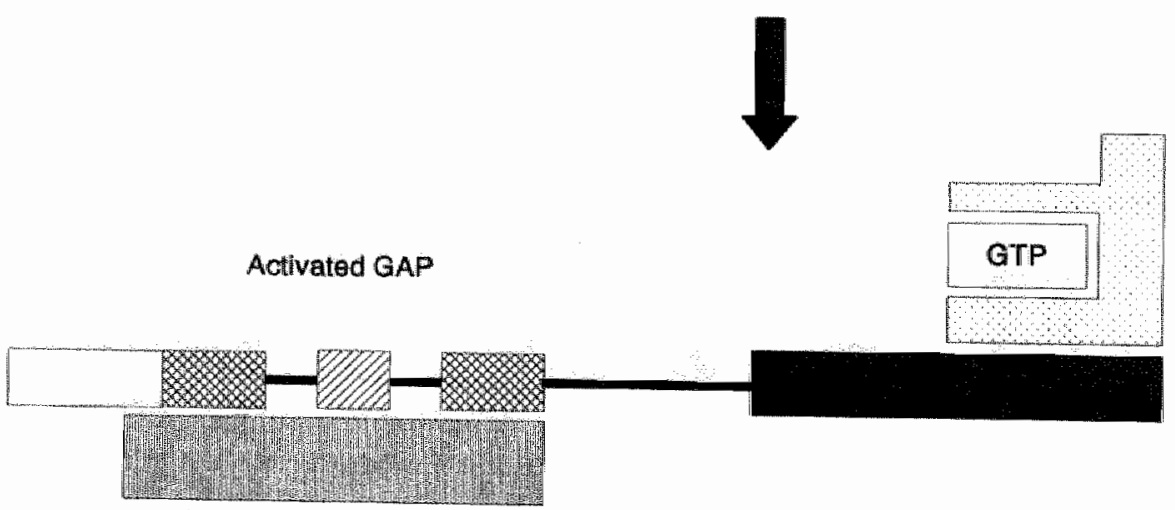

Effector proteins (p190, p62)

Figure 4. Interaction between GAP and activated $\mathrm{p} 21^{\text {ras }}$ proteins. The $\mathrm{SH} 2$ and $\mathrm{SH} 3$ domains of GAP are accessible to effector proteins after binding of $221^{\text {sas }}$ proteins
with GAP (modified from ref. 184). 


\subsubsection{Mutations in the c-Ha-ras gene}

Human tumors frequently harbor pointmutations in one of the c-ras genes (4). The frequency varies in different tumors, ranging from none in neural crest tumors, such as pheochromocytomas (222), to more than $90 \%$ in carcinomas of the exocrine panereas (223). The pointmutations are generally found in amino acid residues 12,13 and 61 $(137,145,224-226)$. Amino acid residue 61 is implicated in the catalytic mechanism of the hydrolysis of GTP into GDP (139 and references therein). The glycines at positions 12 and 13 are not involved in the catalytic mechanism. However, the substitution of these amino acids leads to displacement of other amino acids, which have a role in GTP hydrolysis (139). These pointmutations decrease the intrinsic GTPase activity of $221^{\text {ras }}$ in vitro (227) and inhibit GAP activity under physiological conditions (164), but do not affect the binding of GAP to the effector region (139). In this way, a permanently

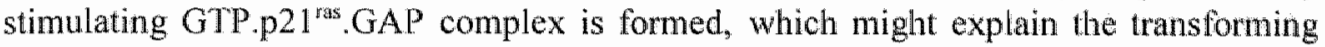
capacity of pointmutated $\mathrm{p} 21^{\text {ras }}$ genes in cancer cells.

Pointmutations introduced by site directed mutagenesis provide further insight in the mechanism of transformation by pointmutated $\mathrm{p} 2 \mathrm{I}^{\mathrm{ras}}$ proteins. Mutations in the carboxyl terminal region prevent the anchoring of $\mathrm{p} 21^{\text {sas }}$ proteins to the inner side of the plasma membrane with concomitant loss of transforming ability $(148,228)$. The reason for this loss is not clear yet. Possibly, the exchange of GDP for GTP in normal. and mutant $\mathrm{p} 21^{\text {ras }}$ proteins might exclusively involve membrane bound GNRP, as has been demonstrated in S. Cerevisae. GDP.p21 RAS associates with membrane-bound CDC25 (229), which catalyzes GDP/GTP exchange specifically at the cell membrane (230).

The substitution of asparagine for serine at position 17 generates a mutant $\mathrm{p} 2 \mathrm{I}^{\mathrm{ras}}$ protein with decreased affinity for GTP, without affecting the affinity for GDP. This mutant blocks the induction of genes, activated in NIH 3T3 cells by stimulation with insulin (231). Most likely, this pointmutated $\mathrm{p} 2 \mathrm{I}^{\text {ras }}$ protein acts as an inhibitor of GNRP, thus preventing the activation of endogenous $\mathrm{p} 21^{\text {ras }}$ proteins $(207,232)$.

As mentioned before pointmutations in codons 12,13 and 61 decrease the intrinsic GTPase activity, but do not affect the interaction with GAP, the putative effector, thus rendering all p2 $1^{\text {ras }}$ proteins similar when mutated (4). Nevertheless, some tumor types harbor pointmutations in one member of the $\mathrm{p} 21^{\text {ras }}$ family only (4). Tumors from the genitourinary tract, such as prostate and bladder carcinoma, contain pointmutations only in the c-Ha-ras gene, whereas exocrine pancreas carcinomas most frequently harbor pointmutations in the $\mathrm{c}-\mathrm{Ki}$-ras gene, and hematopoietic disorders have pointmutations predominantly in the $\mathrm{c}-\mathrm{N}$-ras gene. This suggests differential expression of the members of the $\mathrm{p} 2 \mathrm{I}^{\text {ras }}$ family in different tissues. In some tumor types, such as pheochromocytomas, pointmutations in the c-ras genes have not been found (222). This might be related to the normal function of $\mathrm{p} 21^{\text {ras }}$ proteins in these cells, because the high expression of $\mathrm{p}^{2} 1^{\text {ras }}$ in differentiated cells of the nervous system suggests a role in a specialized cellular function rather than in cell growth $(4,158)$.

However, the fundamentally different responses seem to be mediated by a similar set of proteins (Fig. 3) (233-235). Recent studies suggest that activated receptor protein- 
tyrosine kinases bind the $\mathrm{SH} 2$ domains of cytoplasmic SH2/SH3 adapter proteins. The SH3 domains of the adapter proteins mediate binding to a GNRP, which in turn increases the level of GTP.p $21^{\text {tas }}$ protein $(171,173,175,176,236,237)$. The GTP.p2 $1^{\text {ras }}$ complex may then couple to its effector proteins, such as GAP and/or c-Raf- 1 . Whether or not a cell responds to extracelliular stimuli depends on the available receptors, what the response will be may depend on the cellular "repertoire", but the signal transducing pathway involved may be similar.

\subsubsection{Effects of the introduction of the c-Ha-ras oncogene into cell lines}

In the last decade transfection of the c-Ha-ras oncogene with a pointmutation in codon 12 and other pointmutated members of the $\mathrm{p} 21^{\text {ras }}$ protein family has been applied to investigate the role of these proteins in carcinogenesis and differentiation. For reasons of convenience, the data reviewed here describe the effects of pointmutated $\mathrm{p} 21^{\mathrm{ras}}$ proteins per investigated cell type, but when similar effects were noted in other cell types these are mentioned also.

\section{Fibroblasts}

\section{NIH 3 T3}

The mouse fibroblast-like cell line NIH 3 T3 is immortal but non-tumorigenic in nude mice (238). The introduction of either cellular or viral forms of the Ha-ras oncogene morphologically transforms these cells $(239,240)$. Synthesis of DNA can then be initiated in the absence of serum, indicating a reduced requirement for exogenous growth factors $(239,240)$. The morphologically transformed cells are tumorigenic (238), either with (241-247) or without acquiring spontanous metastatic capacity $(130,248$, 249) when xenografted into nude mice. The variability in metastatic capacity is most likely due to variations in applied methodology (130). The acquisition of metastatic capacity has been correlated with increased expression of the proteases collagenase type IV and u-PA $(247,248)$, with expression of an autocrine motility factor $(250)$ and with increased sialic acid content at the cell surface (251), which supposedly confer new matrix degrading, migratory and adhesive properties to transfected NIH 3T3 cells (15, 252).

Rat Fibroblasts

Introduction of the c-Ha-ras oncogene into second passage rat embryo fibroblasts (REF) induces experimental and spontaneous metastatic capacity in morphologically transformed REF, which is parallelled by increased proteolytic activity $(55,253-255)$. Cytogenetic analysis revealed that metastatic behavior is acquired without chromosomal rearrangements, implying that a diploid cell can be tumorigenic and metastatic (256). Cotransfection of the c-Ha-ras oncogene with the $v$-myc oncogene also induced metastatic behavior in REF cells, in parallel with the emergence of chromosomal rearrangements, and site-specific integration of the c-Ha-ras oncogene close to the centromere of chromosome $3(254,257)$. This may indicate that not only the 
characteristics of the oncogene, but also the site of its integration may contribute to the transfection induced effects (258).

Non-tumorigenic Rat-1 fibroblasts demonstrated a reduced requirement for growth factors after transfection with the pointmutated c-Ha-ras gene or with the wild type cHa-ras gene. Tumorigenic potential was induced in either case, although a modest expression of the $\mathrm{c}-\mathrm{Ha}$-ras oncogene was far more effective than overexpression of the wild type c-Ha-ras gene (259). Overexpression of the wild type c-Ha-ras gene also induced tumorigenicity in NIH 3 T3 cells (244).

Human fibroblasts

Whether or not different ras oncogenes exert similar effects was investigated in nontumorigenic human MSU 1.1 fibroblasts, immortalized by $v$-mye transfection. The introduction of pointmutated $\mathrm{c}-\mathrm{Ha}-, \quad \mathrm{v}-\mathrm{Ki}-$, or $\mathrm{c}-\mathrm{N}$-ras genes morphologically transformed MSU 1.1 cells, which became tumorigenic and invasive in nu/nu mice (260-262). Spontanous metastasis was not observed, but it was suggested that nu/nu mice do not survive the xenograft long enough for metastases to develop (261). Furthermore, reduced growth factor requirement and higher levels of secretion of $\mathrm{U}-\mathrm{PA}$ and $t-P A$ were observed $(260,261,263)$. The karyotype of the transfected cell lines was identical to that of the parental diploid karyotype (260-262). The similarity of the effects on MSU 1.1 cells of either viral or cellular pointmutated N-, Ki- and Ha-ras genes, supports the hypothesis that the functional differences between the members of the $21^{\text {ras }}$ protein family are lost upon mutation.

In the experiments described so far, ras oncogenes were introduced into immortal human fibroblasts or in embryonic rodent fibroblasts. Non-immortalized human fibroblasts can be transformed morphologically by the $\mathrm{c}-\mathrm{N}$ - or the c-Ha-ras oncogene, but the transformed cells do not acquire tumorigenic potential (264-266). Thus, the effects of ras oncogene transfection is determined partly by the recipient cell.

\section{Mammary, prostate, and bladder cells}

Mouse mammary carcinoma and rat prostate adenocarcinoma cells with intrinsic low metastatic capacity became highly metastatic after transfection with pointmutated forms of the c-Ha-ras gene (267-271), without a simple dose-effect relationship between the level of c-Ha-ras expression and metastatic ability $(268,272,273)$. Cytogenetic analysis revealed that genetic instability is increased and it was suggested that this contributes to the increased metastatic ability $(273,274)$. In human mammary cancer cells reduced requirement for growth factors (275), and conversion of non-tumorigenic HBL 100 cells into tumorigenic cells was observed (276).

Human tumorigenic non-invasive papillary transitional cell carcinoma cells became invasive upon overexpression of wild type and pointmutated forms of the c-Hawras gene (277, 278), which was accompanied with increased expression of EGFR (279). However, non-immortalized human urothelial cells could not be converted into tumorigenic cells (278). Thus, the c-Ha-ras oncogene induces neoplastic behavior not 
only in fibroblasts, but also in other cell types, while the recipient cell partly determines the effect of the c-Ha-ras oncogene.

\section{Keratinocytes and hepatocyes}

Transfection of the pointmutated c-Ha-ras gene into immortalized but non-tumorigenic human keratinocytes induced tumorigenicity and invasive behavior. In these cells expression of the cytokeratins $\mathrm{K} 1$ and $\mathrm{K} 10$ was not impaired $(280,281)$. Also, SV40immortalized rat hepatocytes transfected with the c-Ha-ras oncogene become tumorigenic while cell differentiation, as reflected in the expression of genes associated with hepatocyte function such as albumin, was not impaired $(282,283)$. These findings indicate that induction of tumorigenic and invasive behavior by the c-Ha-ras oncogene does not necessarily alter cell differentiation.

\section{Lymphocytes}

Normal human $\| y m p h o c y t e s$ were refractory to transformation after transfection with a pointmutated c-Ha-ras gene (284). In contrast, mouse lymphoma cells became invasive (285) and EBV-immortalized human B-lymphocytes became tumorigenic $(286,287)$. Interestingly, in the latter experiment concomitant induction of plasmacytoid differentiation was observed (287). It was suggested that the c-Ha-ras oncogene stimulates uncontrolled proliferation and triggers terminal differentiation, which is normally blocked in EBV-infected B-cells (287).

\section{Neuroendocrine cells}

The v-Ha-ras oncogene has been reported to induce differentiation in tumor cell lines derived from neural crest tumors $(288,289)$. Increased expression of the peptide hormone calcitonin along with a decrease in cell proliferation and DNA-synthesis, suggested enhanced neuroendocrine differentiation in human medullary thyroid carcinoma cells (288). In the rat pheochromocytoma cell line, $\mathrm{PC12}$, induction of symphathetic neuronal differentiation with concomitant cessation of cell proliferation was reported (289).

Transfection of the pointmutated c-Ha-ras gene into a human small cell lung cancer cell line or in fibroblast-like murine 3T3-L/ cells induced neuroendocrine differentiation and adipocyte differentiation respectively $(290,291)$, which extends the induction of differentiation after transfection with the c-Ha-ras oncogene to other cell types. Hence, these experiments suggest a role for the c-Ha-ras oncogene not only in neoplastic progression, but also in differentiation.

\section{Muscle and melanocyres}

Transfection of the c-Ha-ras oncogene into tumorigenic rat rhabdomyosarcoma cells neither altered growth potential nor induced invasive or metastatic behavior (292). Low metastatic murine K-1735 melanoma cells did not become highly metastatic after transfection with the pointmutated c-Ha-ras gene (293). Also, tumorigenic but non- 
metastatic mouse LTA fibroblast-like cells did not become metastatic after transfection with the pointmutated c-Ha-ras gene (294). These studies suggest that the c-Ha-ras oncogene, at least in these cell lines, is not essential for further malignant progression.

In conclusion, the introduction of the c-Ha-ras oncogene reduces the growth factor requirement in a variety of tumor cells. It is plausible to link this effect to the putative role of the c-Ha-ras gene in the transduction pathway of several growth factors. Immortality of the recipient cell seems to be required for malignant transformation and after transformation the cells retain expression of genes associated with differentiation. In some cells, differentiation can be induced with a concomitant stop of proliferation. The pleiotropic effects of the c-Ha-ras oncogene most likely reflect the putative roles of normal $\mathrm{p} 21^{\mathrm{ras}}$ proteins in proliferation as well as in differentiation.

\subsubsection{The c-Ha-ras oncogene in colorectal cancer}

Pointmutations within the ras genes frequently occur in colon adenomas and carcinomas. They mainly concern the Ki-ras gene $(4,295-298)$ and constitute mostly $\mathrm{G}$ to A transitions (297). The finding that pointmutated Ki-ras genes in adenomas of the lung and the exocrine pancreas are $G$ to $T$ transitions, suggests a specific mechanism for the induction of pointmutations (299). The nature of the inducing agents is as yet obscure, but these may include tissue-specific factors, related to susceptibility to specific carcinogens or activity of certain DNA repair mechanisms, and could also involve chemical mutagens. For all three these tumor types (colon, lung, pancreas) it has to be assumed that the c-Ki-ras gene and not the c-N- or the c-Ha-ras gene is expressed, in order to explain the high specificity for pointmutations in the c-Ki-ras gene.

In about $50 \%$ of colorectal adenomas pointmutations are detected in the c-ras genes and a similar percentage is observed in colorectal carcinomas (297). This prompted the sugggestion that pointmutations develop in the adenoma stage and may be involved in the progression to carcinomas $(3,4)$. However, pointmutated ras genes have been observed also in early stages of colorectal carcinogenesis (296), and are absent in the other $50 \%$ of the colon carcinomas, indicating that the route to a carcinoma can involve more than one pathway.

Pointmutations in the Ki-ras gene were observed with higher frequency in primary colon tumors with metastasis, than in those without $(300,301)$. Moreover, the primary tumor and the metastasis contained the same pointmutation or, when the primary tumor did not harbor a pointmutation, it was not detected either in the metastasis $(300,301)$. This suggests that the pointmutated c-Ki-ras gene must be present in the primary tumor, which renders a clonal selection of c-Ki-ras mutated cells during the metastatic process unlikely. Furthermore, aneuploid colorectal carcinomas have c-Ki-ras pointmutations more frequently than diploid tumors, implicating ras mutations in the development of aneuploidy ( 301$)$. As mentioned before, genetic errors, including aneuploidy, may result from defects in the control of the cell-cycle. One of the factors involved in this regulation, particularly in the onset to mitosis, is the maturation promoting factor 
(MPF), It is therefore of interest to note that MPF can be activated by the introduction of a pointmutated c-Ha-ras gene in Xenopus oocytes $(302,303)$. This indicates a role for p $21^{\text {ras }}$ in the regulation of cell-cycle control.

Data on the mRNA expression of c-ras genes in colorectal cancer is confusing. Elevated mRNA levels of c-Ha- and c-Ki-ras have been observed in tissue homogenates of premalignant and malignant tumors of the colorectum (160). Other studies detected similar levels of cuKi-ras mRNA in normal colon and colorectal cancer tissue (159, 295). Also, data on $\mathrm{p} 21^{\text {ras }}$ protein in colorectal cancer tissue are difficult to interpret. lmmunoblotting with the $\mathrm{p} 21^{\mathrm{ras}}$ monoclonal antibody Y13-259 showed an increased level of $\mathrm{p} 21^{\text {ras }}$ proteins in primary colorectal tumors, classified as Dukes $\mathrm{B}$ and $\mathrm{C}$, whereas p2 $1{ }^{\text {raw }}$ protein level was not increased in most tumors cllassified as Dukes D and their metastases (304). Radioimmunoassays with Y13-259 showed increased expression of $\mathrm{p}^{2} 1^{\text {ras }}$ proteins in most biopsy specimens from colorectal tumors (305). However, the number of colorectal tumors analyzed in both studies was rather small $(304,305)$.

Fairly extensive immunohistochemical studies have been performed to analyze $\mathrm{p} 21^{\text {ras }}$ protein expression at the tissue level. Again, data are difficult to interpret. One study reported no difference in $\mathrm{p} 21^{\text {ras }}$ protein levels between cancer tissue and normal tissue (157). Others detected increased immunoreactivity of $\mathrm{p} 21^{\text {ras }}$ proteins in normal mucosa in the vicinity of tumors or in inflammation (306). The highest immunostaining was noted in villoglandular adenomas, dysplastic adenomas, and carcinomas in situ, and was not related with Dukes stage but rather with the degree of differentiation (306). Taken together, the level of $\mathrm{p} 2 \mathrm{I}^{\text {ras }}$ proteins seems to increase in premalignant tissue, whereas in malignant tissue the level of $\mathrm{p} 21^{\text {ras }}$ proteins may vary.

Thus, the relation between $\mathrm{p} 21^{\text {ras }}$ protein level and carcinogenesis or tumor progression remains obscure. Nevertheless, it is clear that $\mathrm{p} 21^{\text {ras }}$ proteins are components of signal transduction pathways, which are utilized in different cell types of an organism and are evolutionary conserved. It is used by cells to respond to extracellular signals from the microenvironment, and is involved in proliferation as well as in differentiation, depending on the type of cell. Increased proliferation may be central to carcinogenesis, but most likely, can still be regulated by the microenvironment in the early stage of carcinogenesis. This regulation may end when pointmutations in the c-ras genes are present. Constitutive proliferation caused by pointmutated c-ras genes may then increase the genetic instability and speed up the evolution of a premaligmant cell into a malignant cancer cell.

\subsection{AIM AND DESIGN OF THE STUDY}

The reviewed literature indicates that $\mathrm{p} 21^{\text {ras }}$ proteins play a role in colorectal carcinogenesis and cancer progression but the exact mechanism of its involvement is not yet clear. The aim of this study was to gain more insight in the role of the c-Ha-ras oncogene in colorectal carcinogenesis and cancer progression. 
In chapter 2 a study on the behavior of 9 human colorectal carcinoma cell lines in nu/nu mice, after ectopic and orthotopic xenografting, and in the embryonic chick heart fragment assay is described. Cancer cell behavior was correlated with the expression of proteases and cell-adhesion molecules, which have been implicated in invasion and metastasis. Based on the obtained results the cell lines $\mathrm{CaCo} 2$ and $\mathrm{SW} 480$ were selected for further transfection experiments with the c-Ha-ras oncogene in an attempt to elucidate the role of this oncogene in progression of colorectal cancer.

To establish the effects of transfection on the genome it was investigated whether of not integration occurs at specific sites and whether genetic instability increased. In chapter 3 a method is described to identify the chromosomal integration sites of transfected plasmid DNA. In chapter 4 the application of this method is described for the identification of the chromosomal integration sites of plasmid DNA in transfected SW480 cell lines along with a detailed cytogenetic analysis to assess the genetic instability after transfection.

In chapter 5 and 6 the data are presented concerning the phenotypic effects, which were observed in CaCo 2 and SW480 cells after transfection with the c-Ha-ras oncogene, with emphasis on tumorigenic behavior, expression of proteases and cell-adhesion molecules, and degree of differentiation. 


\subsection{REFERENCES}

1. Silverberg E: Cancer Statistics. Cancer. 1981;31:13.

2. Incidence of cancer in The Netherlands 1989. First report of The Netherlands Cancer Registry. Hoonte-Holland bv, Utrecht 1992.

3. Fearon ER, Vogelstein B: gemetic model for colorectal tumorigenesis. Cell. 1990; 61: $759-767$.

4. Bos Jll: Ras oncogenes in human cancer: A revlew. Cancer. Res. 1989; 49:4682-4689.

5. Hartwell L: Defects in a cell cycle checkpoint may be responsible for the genomic instability of cancer cells. Cell. 1992; $71: 543,546$ :

6. Lipkin $\mathrm{M}$ : Biomarkers of increased susceptibility to gastrointestinal cancer: new application to studies of cancer prevention in human subjects. Cancer. Res. 1988; 48 ; $235-245$.

7. Murray AW: Creative blocks: Cell cycle checkpoints and feedback controls. Nature. 1992; 359: 599-604.

8. Liota LA, Rao CN, Barsky SH: Tumor invasion and the extracellular matrix. Lab. Lnvest. $1983 ; 49 ; 636-649$.

9. Bastida E: The metastatic cascade: potential approaches for the inhibition of metastasis. Semin. Thromb. Hemost. 1988; 14: 66-72.

10. Liotta LA." Tumor invasion and metastases: role of the basement membrane. Warner-Lambert Parke-Davis Award lecture. Am. J. Pathol. 1984; 117:339-348.

11. Barsky SH, Togo S, Garbisa $S$, Liotta LA: Type IV collagenase immunoreactivity in invasive breast carcinoma. The Lancet 1983; i: 296-297.

12. Takeichi $\mathrm{M}$ : Cadherin cell adhesion receptors as a morphogenetic regulator. Science. 1991; 251: 1451-1455.

13. Evans CW: Cell adhesion and metastasis. Cell. Biol. Int. Rep. 1992; 16:1-10.

14. Liotta LA, Mandler R, Murano $G$, ef al: Tumor cell autocrine motility factor. Proc. Nanl. Acad. Sci. U. S. A. 1986; 83: 3302-3306.

15. Liotta LA, Steeg PS, Stetler-Stevenson WG: Cancer metastasis and angiogenesis: an imbalance of positive and negative regulation. Cell. 1991; 64: 327-336.

16. Starkey IR: Cell-matrix interactions during tumor invasion. Cancer. Metastasis. Rev. 1990; 9: 113-123.

17. Cohen SM, Ellwein LB: Gemetic errors, cell proliferation, and carcinogenesis. Cancer. Res. 1991: 51:6493-6505.

18. Ames $B N$, Gold $L S$ : Chenical carcinogenesis: too many rodent carcinogens. Proc. Natl. Acad. Sci. U. S. A. 1990; 87:7772-7776.

19. Cohen SM, Ellwein LB: Cell proliferation in carcinogenesis. Science. 1990; 249: 1007-1011.

20. Farber $\mathrm{E}$, Rubin H: Cellular adaptation in the origin and development of cancer. Cancer. Res. 1991; 51: 2751-2761.

21. Stratiss BS: The origin of point mutations in Inuman tumor cells. Cancer. Res. 1992; 52 : 249-253.

22. Peltomaki $\mathrm{P}$, Aattonen $\mathrm{LA}$, Sistonen $\mathrm{P}$, et al: Gentic mapping of a locus predisposing to human colorectal cancer. Science. 1993; 260: 810-812.

23. Aaltonen LA, Peltomaki P, Leach FS, ef al: Clues to the pathogenesis of familial colorectal cancer. Science. 1993; 260:812-816.

24. Enoch $T, N u r s e ~ P$ : Coupling $M$ phase and $S$ phase: controls maintaining the dependence of mitosis on chromosome replication. Cell. 1991; 65: $921-923$. 
25. Loeb LA: Mutator phenotype may be required for multistage eareinugenesis. Cuncer. Res. $1991 ; 51 ; 3075-3079$.

26. Hanawalt PC, Sarasin A: Cancer-prone hereditary diseases with DNA processing abnormalitives. TIG $1986 ; 2: 124,129$.

27. Cleaver JE; Karentz $\mathrm{D}$ : DNA repair in man: Regulation by a multigene family and association with human disease. BioEssays $1987 ; 6: 122-127$.

28. Daya-Grosjean $L$, Robert $C$, Drougard $C$, Suarez $H$, Sarasin $A$ : High mutntion frequency in ras genes of skin tumors isolated from DNA repair deficient Xeroderma pigmentosum patients. Cancer. Res. 1993; 53:1625-1629.

29. Wang $L$, Patel $U$, Ghosli $L$, Banerjee $S$ : DNA polymerase beta mutations in human colorectal cancer. Cancer. Res, 1992; 52: 4824-4827.

30. Vogelstein $B$ : A deadly inheritance. Nature. 1990; 348:681-682.

31. Kastan MB, Onyekwere O, Sidransky D, Vogelstein B, Craig RW: Participation of p53 protein in the cellular response to DNA damage. Cancer. Res. 1991; 51: 6304-6311.

32. Cooper GM., ed: Oncogenes. first ed. Boston: Jones and Bartlett Publishers, 1990

33. Bosman FT, Havenith MG, Visser R, Cleutjens IPM: Basenent membranes in neoplasian Progr. Histochem. Cytochem. 1992; 24: 1-92.

34. Paulsson $M$ : Basement membrane proteins: structure, assembly, and cellular interactions. Crit. Rew. Biochem. Mol. Biol. 1992; 27:93-127.

35. Albini A, Melchiori A, Santi L, Liotta LA, Brown PD, Stetler-Stevenson WG: Tumor cell invasion inhibited by TIMP-2. J. Natl. Cancer. Inst. 1991; 83: 775-779.

36. Khokha $\mathrm{R}$, Zimmer MJ, Graham CH, Lala PK, Waterhouse P. Suppression of invasion by inducible expression of tissue inhibitor of metalloproteinase-1 (TMMP-1) in B16-F10 melanoma cells. J. Natl. Cancer. Inst. 1992;84: 1017-1022.

37. Salo T, Liotta LA, Keski-Oja J, Turpeenniemi-Hujanen T, Tryggvason K: Secretion of basement membrane collagen degrading enzyme and plasminogem activator by transformed cells - Role in metastasis. Int. J. Cancer. 1982; 30:669-673.

38. He CS, Wilhelm SM, Pentland AP, et al Tissue cooperation in a proteolytic cascald activating human interstitial collagenase. Proc. Natl. Acad. Sci. U. S. A. 1989; 86: 2632-2636.

39. Stack MS, Moser TL, Pizzo SV: Binding of human plasminogen to basement-membmane (type IV) collagen. Biochem. J. 1992; 284: 103-108.

40. Dano K, Andreasen PA, Grondahl-Hansen J, Kristensen P, Nielsen I.S, Skriver L: Phasminogein activators, tissue degradation, and cancer. Adv. Cancer. Res. 1985; 44: 139-266.

4.1. Petersen LC, Lund LR, Nielsen LS, Dano K, Skriver L: One-chain arokinase-type plasminogen activator from human sarcoma cells is a proenzyme with little or no intrinsic: activity. J. Biol. Chem. 1988; 263:11189-11195.

42. Kasai $S$, Arimura $H$, Nishida $M$, Suyama $T$ : Primary structure of single-chain pro-urokinase. J. Biol. Chem. 1985; 260: 12382-12389.

43. Blasi F, Vassalli JD, Dano K: Urokinase-type plasminogen activator: proenzyme, recepter, and inhibitors. J. Cell. Biol. 1987; 104:801-804.

44. Ronne E, Behrendt $N$, Ellis V, Ploug $M$, Dano $K$, Hoyer-Hansen G: Cell-induced potentiation of the plasminogen activation system is abolished by a monoclonal antibody that recognizes the NH2-terminal domain of the urokinase receptor." $\mathrm{EBS}$. Lett. 1991; 288: $233-236$.

45. Sprengers ED, Kluft C: Plasminogen activator inhíbitors. Blood. 1987; 69: $381-387$. 
46. Otson $D$, Pollanen J. Hoyer-Hansen $G$, ef al: Internalization of the urokinase-plasminogen activator inbibiter type-l complex is mediated by the urokinase receptor. J. Biol. Chem. $1992: 267: 9129-9133$.

47. Cubellis MV, Wun TC, Blasi F: Receptor-mediated internalization and degradation of urokinatse is caused by its specific inthibitor PAl-1. Embo. J. 1990; 9: 1079-1085.

48. Herz J, Clouthier DE, Hammer RE: LDE receptor-related protein internalizes and degrades IPA-PAI-1 complexes and is essential for embryo implantation. Cell. 1992; 71: 411-421.

49. Cohen RL, Niclas J, Lee WM, af af: Effects of cellular transformation on expression of plasminogen activator inhibitors 1 and 2 . Evidence for independent regulation. $J$. Biol. Chem. 1989; 264:8375-8383.

50. Weigus HG, Stricklin GP: Human skin fibroblast collagenase inhibitor. J. Biol. Chem. 1983 ; 258: $12259-12264$

51. Lu XQ, Lewy $M$, Weinstein IB, Santella RM: Immunological quantitation of levels of tissue inhibitor of metalloproteinase- 1 in human colon cancer. Cancer. Res. 1991; $51: 6231-6235$.

52. Cajot JF, Sordat $B$, Bachmann F: Human primary colon carcinomas xenografted into nude mice. II. Modulation of tumor plasminogen activator activity by the host tissue environment. J. Natl Cancer. Inst. 1986; 77: 1099-1107.

53. Axelrod $\mathrm{JH}$, Reich $\mathbb{R}$, Miskin $\mathrm{R}$ : Expression of human recombinant plasminogen activators enhances invasion and experimental metastasis of H-ras-transformed NIH 3 T3 cells. Mol. Cell. Bioll. 1989; 9: 2133-2141.

54. Hearing VJ, Law LW, Corti A, Appella E, Blasi F: Modulation of metastatic potential by cell surface urokinase of murine melamoma cells. Cancer. Res. 1988; 48: 1270-1278.

55. Bernhard EJ, Muschel RJ, Hughes EN: Mr 92,000 gelatinase release correlates with the metastatic phenotype in transformed rat embryo cells. Cancer. Res. 1990; 50:3872-3877.

56. Quax PHA, van Muijen GNP, Weening-Verhoeff EJD, et al: Metastatic behavior of human melanoma cell lines in nude mice correlates with urokinase-type plasminogen activator, its type-1 inhibitor, and urokinase mediated matrix degradation. J. Cell. Biol. 1991; 115: 191-199.

57. Henderson BR, Tansey WP, Phillips SM, Ramshaw IA, Kefford RF: Transcriptionall and posttranscriptionall activation of urokimase plasminogen activator gene expression in metastatic tumor cells. Cancer. Res. 1992; 52: 2489-2496.

58. Garbisa $S$, Scagliotti $G$, Masiero L, et al: Correllation of serum metalloproteinase levels with lung cancer metastasis and response to therapy. Cancer. Res. 1992; 52; 4548-4549.

59. Hendrix MJ, Wood WR, Seftor EA, et af: Retinoic acid inhibition of human melanoma cell invasion through a reconstituted basement membrane and its relation to decreases in the expression of proteolytic enzymes and motility factor receptor. Cancer. Res. 1990; 50 : $4121-4130$.

60. Turpeenniemi-Hujanen T. Thorgeirsson UP, Hart IR, Grant SS, Liotta LA: Expression of collagenase IV (basement membrane collagenase) activity in murine tumor cell hybrids that differ in metastatic potential. I. Natt. Cancer. Inst. 1985; 75; 99-103.

61. Nakajima $M$, Welch DR, Belloni PN, Nicolson GL: Degradation of basement membrane type IV collagen and lung subendothelial matrix by rat mammary adenocarcinoma cell clones of differing metastatic potentials. Cancer. Res. 1987; 47: 4869-4876.

62. Watanabe $\mathrm{H}$, Nakanishi 1 . Yannashita $\mathrm{K}$, Hayakawa $\mathrm{T}$, Okada $\mathrm{Y}$ : Matrix metalloproteinase-9 (92 kDa gelatinase/type IV collagenase) from U937 monoblastoid cells: Correlation with cellular Invasion. J. Cell Sci. 1993; 104: 991 -999.

63. Hollas W, Blasi F, Boyd D: Role of the mrokinase receptor in facilitating extracellular matrix invasion by cultured colon cancer. Cancer. Res. 1991:51:3690\%3695. 
64. Reiter LS, Kruithof EKO, Cajot J-F, Sordat B: The rolle of the urokintase receptor in extracellular matrix degradation by HT29 human colon careinoma cells. lnt. 1 . Cancer. 1993; $53: 444-450$.

65. Crowley $C W$, Cohen $\mathbb{R L}$, Lucas $B K$, Liu $G$, Shuman MA: Prevention of metastasis by inhibition of the urokinase receptor. Proc. Natl. Acad. Sci. USA 1993; 90:5021-5025.

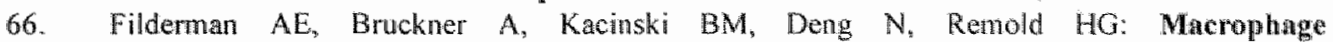
colony-stimulating factor (CSF-1) enhances invasiveness in CSF-1 receptor-positive careinoma cell lines. Cancer. Res. 1992; 52:3661-3666.

67. Bruckner A, Filderman AE, Kurchimeimer JC, Binder BR, Remold HO: Endogenous receptor-bound urokinase mediates tissue invasion of the humam lung carcinoma cell lines A549 and Calu-1. Cancer. Res. 1992; 52: 3043-3047.

68. Ossowski L: Plasminogem activator dependent pathways in the dissemination of human tumor cells in the chick enbryo. Cell. 1988; $52: 321-328$.

69. Reich R. Thompson EW, Iwamoto $\mathrm{Y}$, et al: Effects of inhibitors of plasminogen activator, serine proteinases, and collagenase IV on the invasion of basement membranes by metastatic cells. Cancer. Res. 1988; 48: 3307-3312.

70. Kobayashi $H$, Ohi $H$, Sugimura $M$, Shinohara H, Fujii T, Terao T: Inhibition of in vitro ovarian cancer cell invasion by modulation of urokinase-type plasminogen activator and cathepsin B. Cancer. Res. 1992; $52: 3610-3614$.

71. Khokhia R, Waterhouse P, Yagel S, et al: Antisense RNA-induced reduction in marine TIMP levels confers oncogenicity on Swiss $3 T 3$ cells. Science. 1989;243: 947-950.

72. Pyke C, Rallkiaer E, Tryggvason K, Dano K: Messenger RNA for two type IV collagenases is located in stromal cells in human colon cancer. Am. J. Pathol. 1993; 142: 359-365.

73. Pyke C, Kristensen $\mathrm{P}$, Ralfkiaer $\mathrm{E}$, et al: Urokinase-type plasminogen activator is expressed in stromal cells and its receptor in cancer cells at invasive foci in humain colon adenocarcinomas. Am. J. Pathol. 1991; 138: 1059-1067.

74. Sier $\mathrm{CF}$, Fellbaum $\mathrm{C}$, Verspaget $\mathrm{HW}$, et al: Immunolocalization of urokinase-type plasminogen activator in adenomas and carcinomas of the colorectum. Histopathology. 1991; 19: 231-237.

75. Pyke $C$, Kristensen $P$, Ralfkiaer $E$, Eriksen $J$, Dano $K$ : The plasminogen activation system in haman colon cancer: messenger RNA for the inhibitor PAI-1 is located in endothelial cells in the tumor stroma. Cancer. Res. 1991; 51: 4067-4071.

76. Sier CFM, Werspaget $\mathrm{HW}$, Griffioen $\mathrm{G}$, et al: Imbalance of plasminogen activators and their inhibitors in human colorectal neoplasia. Gastroenterology 1991; 101: 1522-1528.

77. Ossowski $\mathrm{L}$, Clunie $\mathrm{G}$, Masucei $\mathrm{MT}$, Blasi $\mathrm{F}$. In vivo paracrine interaction between urokinase and its receptor: effect on tumor cell invasion. J. Cell. Biol. 1991; 115: $1107-1112$.

78. Albelda SM: Role of integrins and other cell adhesion molecules in tumor progression and metastlasis. Lab. Invest. 1993; 68:4-17.

79. Nose $A$, Tsuji $K$, Takeichi $M$ : Localization of specificity dletermining sites in cadherin celll ad hesion molecules. Cell. 1990; 61: 147-155.

80. Fujimori $T$, Miyatani $S$, Takeichi $M$ : Ectopic expression of $\mathrm{N}$-cadluerin perturbs histogenesis in Xenopus embryos. Development 1990; 110: 97-104.

81. Ozawa $M$, Ringwald $M$, Kemler $R$ : Uvomorulin-catenin complex formation is regulated by a specific domain in the cytoplasmic region of the cell adhesion molecule. Proc. Natl. Acad. Sci. U. S. A. $1990 ; 87: 4246-4250$. 


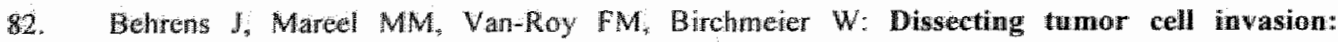
epitheliall cells acquilre invasive properties after the loss of uvomomin-mediated cell-cell adhesion. I. Cell. Biol. 1989: 108: 2435-2447.

83. Hitho $S$, Kimoto $N$, Shimoyama $Y$, Hirohashi $S$, Takeichi $M$ : Identification of a neural alpha-catenin as a key regulator of cadherin function and multicellular organization. Cell. 1992: 70: 293-301.

84. Vleminckx $K$, Vakaet L. $\mathbb{N r}$, Mareel $M$, Fiers $W$, van-Roy $F$ : Genetic manipulation of E-catherin expression by epithelial tumor cells reveals an invasion suppressor rolle. Cell. $1991 ; 66: 107-119$.

85. Horwitz $A$, Duggan $\mathrm{K}$, Buck $\mathrm{C}$, Beckerle $\mathrm{MC}$, Buntige $\mathrm{K}$ : Interaction of plasma membrane fibronectin receptor with tallin - a transmembrane linkage. Nature. 1986; 320:531-533...

86. Behrens $I_{i}$ Vakat $L$, Friis $R_{\text {, er }}$ al: Loss of epithelial differentiation and gain of invasiveness correlates with tyrosine phosphorylation of the E-Cadherin/beta-catenin complex in cells transformed with a temperature-sensitive v-Src gene. J. Cell. Biol. 1993; 120: 757-766.

87. Oka $H$, Shozaki $H$, Kobayashi $K$, at $a l$ : Expression of E-cadherin cell adhesion molecules in human breast cancer tissues and its relationship to metastasis. Cancer. Res. 1993; 53 : $1696-1701$.

88. Schipper JH, Frixen UH, Behrens J, Unger $A$, Jahnke $K$, Birchmeier $W$ : E-cadherin expression in squanous cell carcinomas of head and neck: inverse correlation with tumor dedifferentiation and Jymph mode metastasis. Cancer. Res. 1991; 51: 6328-6337.

89. Umbans R, Schalken JA, Aalders TW, er al: Expression of the cellular adhesion molecule E-cadherin is reduced or absent in high-grade prostate cancer. Cancer. Res. 1992; 52 : 5104-5109.

90. Bussemakers MJ, van-Moorselaar RJ, Giroldi LA, et al: Decreased expression of E-cadherin in the progression of rat prostatic cancer. Cancer. Res. 1992; 52: 2916-2922.

91. Ruggeri B, Camano J, Slaga TJ, Conti CJ, Nelson WJ, Klein-Szanto AJ: Alterations in the expression of uvomorulin and $\mathrm{Na}+, \mathrm{K}(+)$-adenosine triphosphatase during mouse skin tumor progression. Am. J. Pathol. 1992; 140: 1179-1185.

92. Shimoyama $\mathrm{Y}$, Hirohashi $\mathrm{S}$, Hirano $\mathrm{S}$, ef al: Cadherin cell-adhesion molecules in human epithelial tissues and carcinomas. Cancer. Res. 1989;49:2128-2133.

93. van der Wurff AA, ten Kate J, van der Linden EPM, Dinjens WNM, Arends J-W, Bosman FT: L-CAM expression in normal, premalignant, and malignant colon mucosa. J. Pathol. 1992; 168: $287-291$.

94. Dorudi $S$, Sheffield JP, Poulsom $R$, Northover JMA, Hart IR: E-cadherin expression in colorectal cancer; An immunohistochemical and in situ hybridization study. Am. J. Pathol. $1993 ; 142: 981-986$.

95. Hynes RO: Integrins: a family of cell surface receptors. Cell. $1987 ; 48: 549-554$.

96. Hynes RO: Integrins: versatility, modulation, and signaling in cell adhesion. Cell. 1992; 69: $11-25$.

97. Tapley P. Horwitz A, Buck C, Duggan K, Rohrschneider L: Integrins isolated from Rous sarcoma virus-transformed chicken embryo fibroblasts. Oncogene. 1989; 4: 325-333.

98. Schiro IA, Chan BM, Roswit WT, et al: Integrin alpha 2 beta 1 (VLA-2) mediates reorganization and contraction of collagen matrices by human cells. Cell. 1991; 67:

99. Chan BM, Kassner PD, Schiro JA, Byers HR, Kupper TS, Hemler ME: Distinct cellular functions mediated by different VLA integrin alpha subunit cytoplasmic domains. Cell.
1992; 68: 1051-1060. 
100. Azzam HS, Thompson EW: Collagen-induced activation of the M(r) 72,000 type IV collagenase in normal and malignant human nbroblastoid cells. Cancer, Res. 1992; 52 : 4540-4544.

101. Pignatelli M, Bodmer WF: Genetics and biochemistry of collagen binding-triggered glandular differentiation in a human colon carcinoma cell line. Proc. Natl. Acad. Sci. U. $S$. A. $1988 ; 85: 5561-5565$.

102. Pignatelli M, Bodmer WF: Integrin cell adhesion mollecules and colorectal eancer. 1 . Pathol. 1990; 162: 95-97.

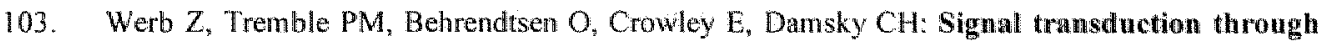
the fibronectin receptor induces collagenase and stromelysin gene expression. J. Cell. Biol. 1989: 109: 877-889.

104. Mortarini R, Gismondi A, Santoni A, Pamiani G. Anichini A: Role of the alpha 5 beta 1 integrin receptor in the proliferative response of quiescent human melanoma cells to fibronectin. Cancer. Res. 1992; $52: 4499-4506$.

105. Pignatelli $M$, Bodmer WF: Integrin-receptor-mediated differentiation and growth inhibition are enhanced by transforming growth factor-beta in colorectal tumour cells grown in collagen gel. lnt. J. Cancer. 1989; 44: 518-523.

106. Ullich $A$, Schlessinger J: Signal transduction by receptors with tyrosine kinase activity. Cell. $1990 ; 61: 203-212$.

107. Fischer EH, Charbonneau H, Tonks NK: Protein tyrosine phosphatases: a diverse family of intracelliular and transmembrane enzymes. Science. 1991; 253: 401-406.

108. Gilman AG: G proteins: transducers of receptor-generated signals. Annu. Rev. Biochem. $1987 ; 56: 615-649$.

109. Juliano RL, Haskill S: Signal transduction from the extracellular matrix. J. Cell. Biol. 1993; 120: $577-585$.

110. Kornberg Ld, Earp HS, Turner CE, Prockop C, Juliano RL: Signal transduction by integrins: increased protein tyrosine phosphorylation caused by clustering of beta 1 integrins. Proc. Natl. Acad. Sci. U. S. A. 1991; 88: 8392-8396.

111. Kanner SB, Reynolds $A B$, Vines RR, Parsons JT: Monoclonal antibodies to individual tyrosine-phosphorylated protein substrates of oncogene-encoded tyrosine kinases. Proc. Natl. Acad. Sci. U. S. A. 1990; 87: 3328-3332.

112. Guan $J$, Shalloway $D$ : Regulation of focal adhesion-associated protein tyrosine kinase by both cellular adthesion and oncogenic transformation. Nature. $1992 ; 358: 690-692$.

113. Hanks $S K$, Calalb MB, Harper MC, Patel SK: Focal adhesion protein-tyrosine kinase phosphorylated in response to cell attachment to fibronectin. Proc. Natl. Acad. Sci. U. S. A. 1992; 89: 8487-8491.

114. Choy MY, Richman PI, Horton MA, MacDonald TT: Expression of the VLA family of integrins in human intestine. 1 . Pathol. $1990 ; 160: 35-40$.

115. Koretz K, Schlag P, Boumsell L, Moller P: Expression of VLA-alpha 2, VLA-alpha 6, and VLA-beta 1 chains in normal mucosa and adenomas of the colon, and in colon carcinomas and their liver metastases. Am. J. Pathol. 1991; 138: 741-750.

116. Somenberg A, Linders CJT, Daams JH, Kennel SJ: The alpha-6-beta-1 (VLA-6) and alpha-6-beta-4 protein complexes: tissue distribution and biochemical properties. $J$, Cell Sci. 1990; 96: 207-217.

117. Bosman FT, de Bruine A, Flohil C, wan der Wurf A, ten Kate $\mathcal{J}$, Dinjens WWM: Epithelial-stromal interactions in collon cancer. Int. J. Dev. Biol. 1993; 37: 203-211.

118. Larjava $\mathrm{H}$, Peltonen I, Akiyama $\mathrm{SK}$, ef al: Novel function for beta 1 integrins in keratinocyte cell-cell interactions. J. Cell. Biol. 1990; 110: 803-815. 
119. Symington BE, Takada $\mathrm{Y}$, Carter WO: Interaction of integrins alpha3 betal and alpha2 beta 1: Potentialrole in heratinocyte intercellular adhesion. J. Cell. Biol. 1993; 120:523-535.

120. Pignatelli $M$, Smith ME, Bodmer WF: Low expression of collagen receptors in moderate and poorly differentiated colorectal adenocarcinomas. Br. J. Cancer. 1990; 61:636-638.

121. Staltwach $A$, van Lampe $B$, Matthes $H$, Bornhoft $G$, Riecken EO: Diminished expression of integrin adhesion molecules on human colonic epithelial cells during the benign to malign transformation. Gut. $1992 ; 33: 342-346$.

122. Humphries $M J$, Olden $K$, Yamada $\mathrm{KM}$; A synthetic peptide from fibronectin inhibits experimental metastasis of murine mellanoma cells. Science. $1986 ; 233: 467-470$.

123. Chan BMC, Matsura N, Takada $Y$, Zetter BR, Hemler $M E$ : In vitro and in vivo consequences of VLA-2 expression on rhabdomyosarcoma cells. Science. 1991; 251: $1600-1602$.

124. Dedhar $S$, Saulnier $R$ : Alterations in integrin receptor expression on chemically transformed human cells: specific enhancement of laminin and collagen receptor complexes. J. Cell. Biol. 1990; 110:481-489.

125. Giancotti FG, Ruostahti E: Elevated levels of the alpha 5 beta 1 fibronectin receptor suppress the transformed phenotype of Chinese hamster ovary cells. Cell. 1990; 60 : 849-859.

126. Zetter BR: The cellular basis of site-specific tumor metastasis. N. Engl. J. Med. 1990; 322: 605-612.

127. Sargent NS, Oestreicher M, Haidwogl $H$, Madnick HM, Burger MM: Growth regulation of cancer metastases by their host organ. Proc. Natl. Acad. Sci. U. S. A. 1988; 85: 7251-7255.

128. Cleutjens $\mathbb{N}$, Haventh $\mathrm{MG}$, Vallinga $\mathrm{M}$, Beek $\mathrm{C}$, Bosman $\mathrm{FT}$ : Monoclonal antibodies to mative basement membranes reveal heterogeneous immunoreactivity patterns. Histochemistry. 1989; 92: 407-412.

129. McBain JA, Weese JL, Meisner LF, Wolberg WH, Willson JK: Establisllment and characterization of human colorectal cancer cell lines. Cancer. Res. 1984; 44: 5813-5821.

130. Wallace JS, Hayle AJ, Syms AJ, ef al: The ras oncogene and tumour metastasis: observations on murine cells transfected with activated human c-Ha-ras. Differentiation. 1989; 41:208-2115.

131. Mareel MM, Van-Roy FM, Messiaen LM, Boghaert ER, Bruyneel EA: Qualitative and quantitative analysis of tumour invasion in vivo and in vitro. J. Cell. Sci. Suppl. 1987; 8:

132. Schor SL, Schor AM, Winn B, Rushton $G$ : The use of threedimensional collagen gels for the study of tumour cell invasion in vitro: experimental parameters influencing cell migration into the gel matrix. Int. J. Cancer. 1982;29;57-62.

133. Mareel MM, De Bruyne GK, Vandesande F, Dragonetti C: Immunohistochemical study of embryonic chick heart invaded by malignant cells in three-dimemsional culture. Invasion. Metastasis. 1981;1:195-204.

134. Chambers AF, Tuck AB: Oncogene transformation and the metastatic phenotype.

135. Fidler 1J: Rationale and methods for the use of nude mice to study the biology and therapy of human cancer metastasis. Cancer. Metastasis. Rev. 1986; 5: 29-49.

136. Fidler $1 J$, Naito $\mathrm{S}$. Pathak $\mathrm{S}$ : Orthotopic implantation is essential for the selection, growth and metastasis of human renal cell cancer in nude mice. Cancer. Metastasis. Rev. 1990; 9 :
$149-165$.

137. Barbacid M: ras genes. Annu. Rew. Biochem. 1987; 56: 779-827. 
138. Boume HR, Sanders DA, McComick $F$ : The GTPase superfamily: conserved structure and molecular mechanism. Nature: $1991 ; 349: 117.127$.

139. Grand RJA, Owen D: The biochenistry of ras p21. Biochen. J. 1991; 279:609-631.

140. Polakis P. McCormick F: Structural requirements for the interaction of $\mathrm{p} 21$ ras with G.AP, Exchange factors, and its biological effector target. J. Biol. Chem. 1993; 268: 9157-9160.

141. Tong LA, de-Vos AM, Milburn MV, Kim SH: Crystall structures at 2.2 A resolution of the catalytic domains of normal ras protein and an oncogenic mutant complexed with GDP. 1. Mol. Biol. 1991; 217: 503-516.

142. John J, Sohmen R, Feuerstein $J_{3}$ Linke R, Wittinghofer A, Goody RS: Kinetics of interaction of nucleotides with nucleotidle-free H-ras p21. Biochemistry. 1990; $29: 60586065$.

143. Chung H-H, Benson DR, Schultz PG: Probing the structure and mechanism of ras protein with an expanded genetic code. Science. 1993; 259:806-809.

144. Capon DJ, Chen EY, Levinson AD, Seeburg PH, Goeddel DV: Complete nucleotide sequences of the T24 human bladder carcinoma oncogene and its normal honologue. Nature. 1983; $302: 33-37$.

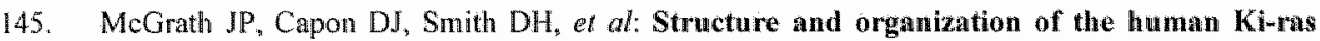
proto-oncogene and a related processed pseudogene. Nature. 1983; 304:501-506.

146. Shimizu K, Birnbatum D, Ruley $\mathrm{MA}_{4}$ et al: Structure of the Ki-ras gene of the human lung carcinoma cell line Calu-1. Nature. 1983; 304: 497-500.

147. Taparowsky $\mathrm{E}$, Shimizu $\mathrm{K}$, Goldfarb $\mathrm{M}$, Wigler $\mathrm{M}$ : Structure and activation of the human N-ras gene. Cell. 1983; 34: $581-586$.

148. Hancock JF, Paterson $\mathrm{H}$, Marshall $\mathrm{CJ}$ : A polybasic domain or palmitoylation is requined in addition to the CAAX motif to localize p21 ras to the plasma membrane. Cell. $1990 ; 63$; 133-139.

149. Marshall MS, Davis $L J$, Keys RD, et al: Identification of amino acid residues required for Ras p21 target activation. Mol: Cell. Biol. 1991; 11: 3997-4004.

150. Haubruck H, McCormick F: Ras p21: effects and regulation. Biochim. Biopliys. Acta. 1991; 1072: 215-229.

151. Fukui Y, Kozasa T, Kaziro Y, Takeda T, Yamamoto M: Role of a ras homolog in the life cycle of Schizosaccharomyces pombe. Cell. 1986; 44:329-336.

152. Han M, Sternberg PW: lett-60, a gene that specifies cell fates during $C$. elegans vulval induction, encodes a ras protein. Cell. 1990; 63: 921-931.

153. Beitel GJ, Clark SG, Horwitz $\mathrm{R}$. Caenorhabditis elegans ras gene let-60 acts as a switch in the pathway of vulval ind uction. Nature. $1990 ; 348: 503-509$.

154. Simon MA, Bowtell DD, Dodson GS, Laverty TR, Rubin GM: Ras I and a putative guanine nucleotide exchange factor perform crucial steps in signaling by the sevenless protein tyrosine kinase. Cell. 1991; 67:701-716.

155. Fortini ME, Simon MA, Rubin GM: Signalling by the sevenlless protein tyrosine kinase is mimicked by Rasl activation. Nature. 1992;355:559-561.

156. Greenwald I, Rubin GM: Making a difference: the role of cell-cell interactions in establishing separate identities for equivalent cells. Cell. $1992 ; 68 ; 271-281$.

157. Chesa $\mathrm{PG}_{3}$, Rettig WJ, Melamed MR, Old LJ, Niman HL: Expression of p2l ras in normal and maligmant human tissues: lack of association with proliferation and malignancy. Proc. Natl. Acad. Sci. U. S. A. 1987; 84:3234-3238.

158. Furth ME, Aldrich TH, Cordon-Cardo C: Expression of ras protomoncogene proteins in normal human tissues. Oncogene. $1987 ; 1 ; 47-58$.

159. Untawale $S$, Blick $M$ : Oncogene expression in adenocarcinomas of the colon and in colon tumor-derived cell lines. Anticancer. Res. 1988; 8: 1-7. 
160: Spandidos DA, Kerr UB: Elewated expression of the human ras oncogene family in premalignant and malignant tumours of the colvectum. Br. J. Cancer. 1984; 49:681-688.

161. West $M$, Kung $H F_{\text {" Kamata }} \mathrm{F}$ : A novel membrane factor stimulates guanine nucleotide exchange reaction of ras proteins. FEBS. Lett. 1990; 259:245-248.

162. Wolfman A, Macara IG: A cytosolic protein catalyzes the release of GDP from p21 ras. Science. $1990,248: 67-69$.

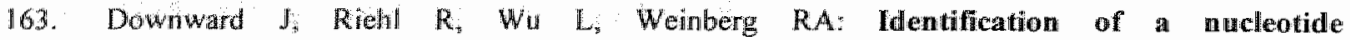
exchangepromoting activity for p21 ras. Proc. Natl. Acad. Sci. U. S. A. $1990 ; 87$ : 5998-6002:

164. Trahey $M$, McCormick F: A cytoplasmic protein stimulates normal N-ras p21 GTPase, but does not affect oncogenïc mutants: Science: $1987 ; 238: 542-545$.

165. Xu GF, $O^{\prime}$ Connell $P$. Viskochil $D$, et al: The neurofibromatosis type 1 gene encodes a protein related to GAP. Cell. 1990; $62 ; 599-608$.

166. Ballester R, Marchuk D, Boguski $M$, er al: The NIF1 locus encodes a protein functionally related to mammallian GAP and yeast IRA proteins. Cell. 1990;63:851-859.

167. de-Vos $\mathrm{AM}$, Tong $\mathrm{L}$, Milburis MV, ef al: Three-dimensionall structure of an oncogene protein: catalytic domain of human c-H-ras p21. Science. 1988; 239:888-893.

168. Hall A: Signal transduction through small GTPases-a tale of two GAPs. Cell. 1992; 69: 389-391.

169. Vogel US, Dixon RA, Schaber MD, et al: Cloning of bovine GAP and its interaction with oncogenic ras p21. Nature. 1988; 335:90-93.

170. Koch CA, Anderson D, Moran MF, EIlis C, Pawson T: SH2 and SH3 domains: elements that control interactions of cytoplasmic signaling proteins. Science. 1991; 252:668-674.

171. Pawson T, Gish GD: SH2 and SH3 domains: from structure to function. Cell, 1992; 71 : 359-362.

172. Cantley $\mathrm{L}$, Auger $\mathrm{KR}$, Carpenter $\mathrm{C}$, et al: Oncogenes and signal transdluction. Cell. 1991; 64:
$281-302$.

173. Songyang $Z$, Shoelson SE, Chaudhuri $M_{3}$ et al: SH2 domains recognize specific phosphopeptide sequences. Cell: 1993; 72: 767-778.

174. Simon MA, Dodson GS, Rubin GM: An SH3-SH2-SH3 protein is required for p21 ras1 activation and binds to sevenless and sos proteins in vitro. Cell. 1993; 73:169-177.

175. Olivier IP, Raabe T, Henkemeyer M, et al: A drosophila SH2-SH3 adaptor protein implicated in coupling the sevenless tyrosine kinase to an activator of ras guanime
nucleotide exchange, sos. Cell. $1993 ; 73: 179-191$.

176. Buday $\mathrm{L}$, Downward $\mathrm{J}$ : Epidermal growth factor regulates $\mathrm{p} 21$ ras through the formation of 1993:73: 611-620.

177. Rozakis-Adcock $M$, Fernley $R$, Wade J, Pawson T, Bowtell D: The SH2 and SH3 domains of mammalian Girb2 couple the EGF receptor to the Ras activator mSos. Nature. 1993; 363:
83-85.

178. Tsai MH, Yu CL, Wei FS, Stacey DW: The effect of GTPase activating protein upon ras is inhibited by mitogenically responsive lipids. Science. 1989;243:522-526. in phospholipid-dependent a cytoplasmic protein inhibits the GTPase activity of H-Ras

180. Majerus PW: Inositol phosphatenaner. Science. 1990; 250: 982-985.

181. Yatani A, Okabe K, Polakis P. Hallentemistry. Annu. Rev. Biochem. 1992; 61: 225-250. inhibit cowpling of muscarinic receptors to atrial $K+$, Hallenbeck $R$, Brown AM: ras p21 and GAP 


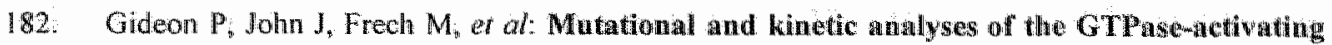
protein (GAP)-p21 interaction: the C-terminal domain of GAP is not sufficient for full activity. Mol. Cell. Biol. 1992;12: $2050-2056$

183. Medema RH, de-Laat WL, Martin GA, McComick F, Bos JL: GTPase-activating protein SH2-SH3 domains induce gene expression in a Ras-dependent fashion. Mol. Call. Bol. 1992; $12: 3425-3430$.

184. Martin GA, Yatani A, Clark R, et al: GAP domains responsible for Ras p2l-dependent in hibition of muscarinic atrial $K+$ chammel currents. Nature. 1992; $255: 192-194$.

185. Marshall MS, Hettich LA: Characterization of Ras effector mutant interactions with the NF1-GAP related domain. Oncogene. 1993; 8:425-431.

186. Bollag $G$, MoCormick $F$, Clark $\mathbb{R}$ : Characterization of full-length nenrofibromin: Tubullin inhibits Ras GAP activity. The EMBO Journal 1993; 12: 1923-1927.

187. MoGlade $\rrbracket$, Brunkhorst $B$, Anderson D, ef $a$ : The N-terminal region of GAP regulates cytoskeletal structure and cell adhesion. The EMBO Journal 1993: 12:3073-3081.

188. Hughes DA, Fukui $Y$, Yamamoto M: Homologous activators of ms in fission and budlding yeast. Nature. 1990; 344: $355-357$.

189. Jones $\mathrm{S}$, Vignais M-L, Broach JR: The CDC25 protein of Saccharomyces cerevisae promotes excluange of guanune nucleotides bound to Ras. Moll. Cell. Biol. 1991; 11: 2641-2646.

190. Rogge RD, Karlovich CA, Banerjee U: Genetic dissection of a neurodevelopmentall pathway: Son of sevenless functions downstream of the sevenless and EGF receptor tyrosinc kinases. Cell. $1991 ; 64: 39-48$.

191. Wang $Y$, Boguski $M$, Riggs $M$, Radgers $L$, Wigler $M$ : Sarl, a gene from Schizosaceharomyces pombe encoding a protein that regulates ras 1. Cell. Regul. 1991; 2 : 453-465.

192. Imai $\mathrm{Y}$, Miyake $\mathrm{S}$, Hughes DA, Yamamoto M: Identification of a GTPase-activating protein homolog in Schizosaccharomyces pombe. Mol. Cell. Biol. 1991; 11: 3088-3094.

193. Gaul U, Mardon $G$, Rubin GM: A putative Ras GTPase activating protein acts as a negative regulator of signaling by the Sevenless receptor tyrosine kinase. Cell. 1992; 68: 1007 1019.

194. Pusztai L, Lewis CE, Lorenzen J, McGee JO'D: Growth factors: Regulation of normal and neoplastic growth. J. Pathol: 1993; 169: 191-201.

195. Molloy CJ, Fleming TP, Bottaro DP, Cuadrado A, Aaronson SA: Platelet-derived growth factor stimulation of GTPase-activating protein tyrosine phosphorylation in control and c-H-ras-expressing NIH 3 T3 cells correlates with p21 ras activation. Mol. Cell. Biol. 1992; 12: $3903-3909$.

196. Satoh $T$, Endo $M$, Nakafuku $M$, Akiyama $T$, Yamamoto $T$, Kaziro $Y$ : Accumulation of p21 ras.GTP in response to stimulation with epidermal growth factor and oncogeme products with tyrosine kinase activity. Proc. Natl. Acad. Sci. U. S. A. 1990; 87: 7926\%7929.

197. Satoh T, Endo $M$, Nakafuku $M$, Nakamura $S$, Kaziro $Y$ : Platelet-derived growth factor stimulates formation of active p21ras.GTP complex in Swiss mouse 3 T3 cells. Proc. Natl. Acad. Sci. U. S. A. 1990; 87: 5993-5997.

198. Reedijk $M_{*}$ Liu $X Q$, Pawson $T$ : Interactions of phosphatidyllinositol kinase, GTPase-activating protein (GAP), and GAP-associated proteins with the colony-stinulating factor 1 receptor. Mol. Cell. Biol. 1990; 10:5601-5608.

199. Molloy CJ, Bottaro DP, Fleming TP, Marshall MS, Gibbs JB, Aaronson SA: PDGF induction of tyrosine phosphorylation of GTPase activating protein. Nature. 1989;342: $711-714$.

200. Margolis B, Li N, Koch A, et al: The tyrosine phosphorylated carboxyterminus of the EGF receptor is a binding site for GAP and PLC-gamma. Embo. J. 1990; 9:4375-4380. 
201. Kaplan DR, Morrison DK, Wong $G_{3}$ MeCormick $F$, Williams LT: PDGF beta-receptor stimulates tyrosine phosphorylation of $G A P$ and association of GAP with signaling complex. Cell. $1990 ; 61: 125-133$.

202. Kazlauskas $A_{;}$Ellis $C$, Pawson $T$, Cooper JA: Binding of GAP to activated PDGF receptors. Science. $1990 ; 247: 1578-1581$.

203. Yarden $Y$, Ullich $A$ : Growth factor receptor tyrosine kinases. Annu. Rew. Biochem. 1988; 57: 443-478.

204. Morrison $\mathrm{DK}$, Kaplan $\mathrm{DR}$, Rhee $\mathrm{SG}$; Williams LT: Mlatelet-derived growth factor (PDGF)-dependent association of phospholipase C-gamma with the PDGF receptor signaling complex. Mol. Cell. Biol. 1990; 10: 2359-2366.

205. Kazlauskas $A_{*}$ Kashishian $A$, Cooper JA, Valius $M$ : GTPase-activating protein and phosphatidylinositol 3-kinase bind to distinet regions of the platelet-derived growth factor receptor beta subunit. Moll. Cell. Biol. 1992; 12: 2534-2544.

206. Basu TN, Gutmann DH, Fletcher JA, Glover TW, Collins FS, Downward J: Aberrant regulation of ras proteins in malïgnant tumour cells from type 1 neurofibromatosis patients. Nature. 1992; 356:713-715.

207. Medema RH, de Vries-Smits AMM, van der Zon GCM, Maassen JA, Bos JL: Ras activation by insulin and epidermal growth factor through enhanced exchange of guanine nucleotides on p21 ras. Mol. Cell. Bioll. 1993; 13: 155-162.

208. Buday L, Downward J: Epidermal growth factor regulates the exchange rate of guanine nucleotides on p21 ras in fibroblasts. Mal. Cell. Biol. 1993; 13: 1903-1910.

209. Ellis C, Moran M, McCornick F, Pawson T: Phosphorylation of GAP and GAP-associated proteins by transforming and mitogenic tyrosine kinases. Nature. 1990; 343: 377-381.

210. Wong $G$, Muller $O$, Clark. $R$, et at: Mollecular cloning and nucleic acid binding properties of the GAP-associated tyrosine phosphoprotein p62. Cell. 1992; 69:551-558.

211. Settleman $d$, Narasimhan $V$, Foster LC, Weinberg RA: Molecular cloning of cDNAs encoding the GAP-associated protein p190; implications for a signaling pathway from ras to the nucleus. Cell. 1992; 69: 539-549.

212. Rossomando AJ, Payne DM, Weber $\mathrm{MJ}_{2}$ Sturgill $\mathrm{TW}$ : Evidence that pp42, a major tyrosine kimase target protein, is a mitogen-alctivated serine/threonine protein kinase. Proc. Natl. Acad. Sci. USA 1989; 86: 6940-6943.

213. Crews CM, Alessandrini A, Erikson RL: Erks: Their fifteen minutes has arrived. Cell Growth and Differentiation 1992; 3: 135-142.

214. Davis RJ: The mitogen-activated protein kinase signal transduction pathway. J. Biol. Chen. $1993 ; 268: 14553-14556$.

215. Alvarez A, Northwood 1C, Gonzalez FA, et at: Pro-Leu-Ser/Thr-Pro is a consensus primary sequence for substrate protein phosphorylation. I. Biol. Chem. $1991 ; 266: 15277-15285$.

216. Seth A, Alvarez E, Gupta $S$, Davis RJ: A phosphorylation site located in the NH2-terminal domain of c-Myc increases transactivation of gene expression. J. Biol. Chem. 1991; 266: 23521-23524.

217. Kyriakis IM, App H, Zhang X-f, ef al: Raf-1 activates MAP kinase-kinase. Nature. 1992; 358: 417-420.

218. Howe L.R, Leevers SJ, Gomez N, Nakiehy S, Cohen P, Marshall CJ: Activation of the MAP kinase pathway by the protein kinase raf. Cell. 1992; 71:335-342.

219. Vojtek AB, Hollenberg SM, Cooper IA: Mammalian Ras interacts directly with the serine/threonine kinase Raf. Cell. 1993; 74: 205-214.

220. Zhang $X-f$, Settleman J, Kyriakis JM, er al: Normal and oncogenic p21 ras proteins bind to the amino-terninal domain of c-Raf-1. Nature. 1993; 364: 308-313. 
221. Warns PH, Viclana $P R$, Downward $\mathbf{J}$ : Direct interaction of $\mathbf{R}$ s and the amino-terminall region of Raf-1 in vitro. Nature. $1993 ; 364 ; 352-355$

222. Moley JF, Brother MB, Wells SA, Spengler BA, Biedler JL, Brodeur OM: Low frequency of ras gene mutations in neuroblastomas, pheochromocytomas, and medullary thyrodi cancers. Cancer. Res. 1991; 51 : 1596-1599.

223. Almoguera C, Shibata D, Forrester K. Martin J. Armheim N, Perucho M: Most human carcinomas of the exocrine pancreas contain unutant $\mathrm{C}-\mathrm{K}$-ras genes. Cell. 1988; 53 : 549-554.

224. Reddy EP, Reynolds RK, Santos E, Barbacid $M$ : A pointmutation is responsible for the acquisition of transforming properties by the T24 human bladder carcinoma oncogene. Nature. 1982; 300: 149-152.

225. Tabin $\mathrm{CJ}$, Bradley $\mathrm{SM}$, Bargmann $\mathrm{Cl}$, et al: Mechanism of activation of a human oncogene. Nature, 1982; 300: 143-149.

226. Bos JL, Toksoz D, Marshall $\mathrm{CJ}$, et al: Amino-acid substitutions at codon 13 of the N-ras oncogene in human acute myeloid leukaemia. Nature. 1985; 315: 726-730.

227. Manne V, Bekesi $\mathbb{E}$, Kung HF: Ha-ras proteins exhibit GTPase activity: point mutations that activate Ha-ras gene products result in decreased GTPase activity. Proc. Natl. Acad. Sci. U. S. A. $1985 ; 82: 376-380$.

228. Buss JE, Solski PA, Schaeffer JP, MacDonald MJ, Der CJ: Activation of the cellular proto-oncogene product p21Ras by addition of a myristylation signal. Science. $1989 ; 243$ : 1600-1603.

229. Munder T, Furst $P$ : The Saccharomyces cerevisiae CDC25 gene product binds specifically to catalytically inactive ras proteins in vivo. Mol. Cell. Biol. 1992; 12: 2091-2099.

230. Gross E, Goldberg D, Levitzki A: Phosphorylation of the $\mathbf{S}$. cerevisae Cde25 in response to glucose resuits in its dissociation from Ras. Nature. 1992; 360: 762-765.

231. Medema $\mathrm{RH}$, Wubbolts $\mathbb{R}$, Bos JL: Two dominant inhibitory mutants of $\mathbf{2} 1 \mathrm{ras}$ interfere with insulin-induced gene expression. Mol. Cell. Biol. 1991; 11:5963-5967.

232. Feig LA, Cooper GM: Inhibition of NIH 3T3 cell proliferation by a mutant ras protein with preferential affinity for GDP. Mol. Cell. Biol. 1988; 8: 3235-3243.

233. Feig LA: The many roads that lead to ras. Science. 1993; 260: 767-768.

234. McCormick F: How reeeptors turn Ras on. Nature. 1993; 363: 15-16.

235. Perrimon $\mathrm{N}$ : The torso receptor protein-tyrosine kinase signaling pathway: An endless story. Cell. 1993; $74: 219-222$.

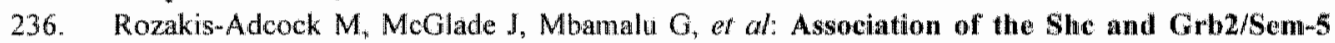
SH2-containing proteins is implicated in activation of the Ras pathway by tyrosine kinases. Nature. 1992: 360: 689-692.

237. Egan SE, Giddings BW, Brooks MW, Buday L, Sizeland AM, Weinberg. RA: Assoeiation of Sos Ras exchange protein with $\mathrm{Grb} 2$ is implicated in tyrosine kinase signal transduction and transformation. Nature. 1993; 363:45-51.

238. Chang EH, Furth ME, Scolnick EM, Lowy DR: Tumorigenic transformation of mammalian cells induced by a normal human gene homologous to the oncogene of Harvey murine sarcoma virus. Nature. $1982 ; 297: 479-483$.

239. Feramisco JR, Gross M, Kamata T, Rosenberg M, Sweet RW: Microinjection of the oncogene form of the human H-ras (T-24) protein results in rapid proliferation of quiescent cells. Cell. 1984; 38: 109-117.

240. Stacey DW, Kung H-F: Transformation of NIH 3T3 cells by microinjection of Haras p21 protein. Nature. 1984:310:508-511. 
241. Egan $\mathrm{SE}$, Wright $\mathrm{JA}$, Jarolim $\mathrm{L}$, Yanagihara $\mathrm{K}$, Bassim RH, Greenberg $\mathrm{AH}$ : Transformation by oncogenes encoding protein dinases indwces the metastatic phenotype. Science. 1987; 238: $202-205$.

242. Egan $\mathrm{SE}_{3}$ McClarty $\mathrm{GA}$, Jarolim $\mathrm{L}$, of al: Expression of $\mathrm{H}$-ras correllates with metastatic potential: evidence for direct regulation of the metastatie phenotype in $10 \mathrm{TI} / 2$ and NIH 3T3 cells. Mol. Cell. Bjol. 1987: 7: 830-837.

243. Chambers $A F$, Denhard $G H$, Wision SM: ras-transformed NIH $3 T 3$ cell lines, selected for metastatic ability in chick embryos, have increased proportions of $\mathbf{p} 21$-expressing cells and are metastatic in mude mice. Invasion. Metastasis. 1990; 10:225-240.

244. Egan $5 E$, Broer JJ, Jarolin $L$, Wright JA, Greenberg AH: Co-regulation of metastatic and transforming activity of normal and mutant ras genes. Int. J. Cancer. 1989; 43: 443-448.

245. Bradley $M O$, Kraynak $A R$, Storer $R D$, Gibbs JB. Experimental metastasis in nude mice of NIH 3 T3 cells containing various ras genes. Proc. Nat. Acad. Sci. U. S. A. 1986; 83: 5277-5281.

246. Muschel RJ, Williams JE, Lowy DR, Liotta LA: Harvey ras induction of metastatic potential depends upon oncogene actiwation and the type of recipient cell. Am. J. Pathol. 1985; 121: $1-8$.

247. Thorgeirsson UP, Turpeenniemi-Hujanen $T$, Williams JE, et al: NIH/3T3 cells transfected with human tumor DNA containing activated ras oncogenes express the metastatic phenotype in nude mice. Mol. Cell. Biol. 1985; 5: 259-262.

248. Sidhu MK, Russo MS, Zirvi KA, Scala L, Kumar S: Tumorigenicity of EJ-ras oncogene transformed NIH 3 T 3 cells and expression of plasminogen activators. Cell. Biol. Int. Rep. $1990 ; 14: 527-542$.

249. Hill SA, Wilson S, Chambers AF: Clonal heterogeneity, experimental metastatic ability, and p21 expression in H-ras-transformed NIH 3T3 cells. J. Natl. Cancer. Inst. 1988; 80; 484-490.

250. Seiki M, Sato H, Liotta LA, Schiffmann E: Comparison of autocrine mechanisms promoting motility in two metastatic cell lines: human melanoma and ras-transfected NIH3T3 cells. Int. J. Cancer. 199॥; 49:717-720.

251. Bolscher JG, van-der-Bijl MM, Neefjes JJ, Hall A, Smets LA, Ploegh HL: Ras (proto)oncogene induces $\mathrm{N}$-linked carbohydrate modification: temporal relationship with induction of invasive potential. Embo. $\mathbb{J}$. 1988; 7:3361-3368.

252. Springer TA: Adhesion receptors of the immune system.. Nature. 1990; 346:425-434.

253. Pozzatii $R$, Muschell $\mathbb{R}$, Willians $J$, et al: Primary rat embryo cells transformed by one or two oncogenes show different metastatic potentials. Science. 1986;232: 223-227.

254. Garbisøi S, Pozzalti R, Muschel RJ, al : Secretion of type IV collagenolytic protease and metastatic phenotype: induction by transfection with c-Ha-ras but not c-Ha-ras plus Ad2-E1a. Cancer. Res. 1987; 47: 1523-1528.

255. Spandidos DA, Wilkie NM: Maliggmant transformation of early passage rodent cells by a single mutated human oncogene. Nature. 1984; 310:469-475.

256. Muschel RJ, Naikahara K. Chu E, Pozzatti R, Liota LA: Karyotypic analysis of diploid or near diploid metastatic Harvey ras transformed rat embryo fibroblasts. Cancer. Res. 1986;
46: $4104-4108$.

257. MoKenna WG, Nakahara $K$, Muschel RJ: Site-specific integration of H-ras in transformed rat embryo cells. Science. 1988; 241: 1325-1328.

258. Bardwell $L$ : The mutagenic and carcinogenic effects of gene transfer. Mutagenesis. $1989 ; 4$ :
$245-253$.

259. Ricketts $\mathrm{MH}$, Levinson AD: High-level expression of c-H-rasl fails to fully transform rat-1 cells. Mol. Cell. Biol. 1988; 8: 1460-1468. 
260. Hurlin PJ, Maher VM, McCormick JI: Malignant trausformation of human fibroblasts caused by expression of a transfected T24 IRAS oncogene. Proc. Nat. Acad. Set. U. $\$$. A. 1989:86:187-191.

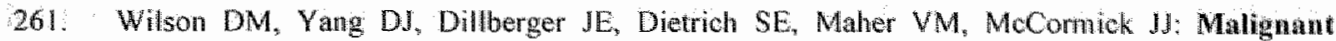
transformation of human fibroblasts by a transfected $\mathbf{N}$ mas oncogene. Cancer. Res. 1990; 50: $5587-5593$.

262. Fry DG, Milam LD, Dillberger JE, Malrer VM, McCormick JI: Malignant transformation of an infinite life span human fibroblast cell strain by transfection with v-Ki-ras. Oncogene. $1990 ; 5: 1415-1418$

263. Jankun J, Maher VM; McCormick $\mathbb{J}$ : Malignant transformation of human fibroblasts correlates with increased activity of receptor-bound plasminogen activator. Cancer. Res. 1991: $51: 1221-1226$.

264. Wilson DM, Fry DG, Maher VM, McCormick IJ: Transfonmation of diploid haman fibroblasts by transfection of N-ras-oncogenes. Carcinogenesis. 1989; 10:635-640.

265. Sager $R$, Tanaka $K$, Lau $C C$, Ebina $Y$, Anisowice $A$ : Resistance of human cells to tumorigenesis induced by cloned transforming genes. Proc. Natl. Acad. Sci. U. S. A. 1983; 80:7601-7605.

266. Kinsella AR, Fiszer-Maliszewska L, Mitchell EL, Guo YP, Fox M, Scott D: Introduction of the activated $\mathrm{N}$-ras oncogene into human fibroblasts by retroviral vector induces morphological transformation and tumorigenicity. Carcinogenesis. 1990; 11: 1803-1809.

267. Kerbel RS, Waghome C. Man MS, Elliott B, Breitman ML: Alteration of the tumonigenic and metastatic properties of neoplastic cells is associated with the process of calcium phosphate-medisted DNA transfection. Proc. Nati. Acad. Sci. U. S. A. 1987; 84: 1263-1267.

268. Kyprianou $N_{3}$, Isaacs JT: Relationship between metastatic ability and H-ras oncogene expression in rat mammary cancer cells transfected with the v-H-ras oncogene. Cancer. Res. 1990; 50: 1449-1454.

269. Vousden KH, Eccles SA, Purvies H, Marshall CJ: Enhanced spontameous metastasis of mouse carcinoma cells transfected with an activated c-Hla-ras-1. gene. Int. J. Cancer. 1986; 37: $425-433$.

270. Treiger B, Isaacs J: Expression of a transfected $v$-Harvey-ras oneogene in a Dunning rat prostate adenocarcinoma and the development of high metastatic ability. J. Urol. 1988 ; 140: $1580-1586$.

271. Partin AW, Isarcs JT, Treiger B, Coffey DS: Early cell motility changes associated with an increase in metastatic ability in rat prostatic cancer cells transfected with the v-Harvey-ras oncogene. Cancer. Res. 1988; 48:6050-6053.

272. Cooke DB, Quarmby VE, Petrusz P, at: Expression of ras proto-oncogenes in the Dumning R3327 rat prostatic adenocarcinoma system. Prostate. 1988; 13:273-287.

273. Ichikawa T, Schalken JA, Ichikawa $Y$, Steinberg GD, Isaacs JT: H-ras expression, genetic instability, and acquisition of metastatic abillity by rat prostatic cancer cells following v-H-ras oncogene transfection. Prostate. 1991; $18: 163-172$.

274. Ichikawa T, Kyprianou N, Isaacs JT: Genetic instability and the acquisition of metastatic ability by rat mammary cancer cells following v-Huras oncogene transfection. Cancer. Res. $1990 ; 50: 6349-6357$.

275. Ciardiello F, McGeady ML, Kim N, et al: Transforming growth factor-allpha expression is enhanced in human mammary epithelial cells transformed by an activated c-Ha-ras protooncogene but not by the c-neu protooncogene, and overexpression of the transforming growth lactor-alpha complementary DNA leads to transformation. Cell. Growth. Differ. 1990; 1: 407-420. 
276. Lebeau J, Le-Chalony C, Prosperi MT, Goubin G: Constitutive overexpression of a $89 \mathrm{kDa}$ heat shoek protein gene in the HBLI00 human mammary cell line converted to at tumorigenie phenotype by the EJ/T24 Harwey-ras oncogene. Oncogene, 1991; 6: 1125-1132.

277. Theodoreseu D, Comil I, Fernandez BI, Kerbel RS: Overexpression of normal and mutatied forns of HRAS induces orthotopic bladder invasion in a human transitional cell carcinoma. Proc: Natl. Acad. Sci. U. S. A. 1990; 87: 9047-9051.

278. Pratt Cl, Kao CH, Wu SQ, Gilchrist KW, Oyasu R, Reznikoff CA: Neopdastic progression by Eu/ras at different steps of transformation in vitro of human uroepithelial cells. Cancer. Res. 1992; $52: 688-695$.

279: Theodorescu D. Corni I, Sheethan C, Man MS, Kerbel RS: Ha-ras induction of the invasive phenotype results in up-regulation of epidermal growth factor receptors and altered responsiveness to epidermal growth factor in human papillary transitional cell carcinoma cells. Cancer. Res; 1991; $51: 4486-4491$.

280. Dotto $\mathrm{OP}^{\mathrm{P}}$. Weinberg RA, Ariza A: Malignant transformation of mouse primary keratinocytes by Harvey sarcomat virus and its modulation by surrounding mormall cells. Proc. Natl Acad. Sci. U. S. A. 1988; 85: 6389-6393.

281. Boukamp P. Stanbridge EJ, Foo DY, Cerutti PA, Fusenig NE: c-Ha-ras oncogene expression in inmortalized humian keratinocytes (HaCaT) alters growth potential in vivo but lacks correlation with malignancy. Cancer. Res. 1990; 50:2840-2847.

282. Fang $X J$, Flowers $M$, Keating $A_{y}$ Cameron $R$, Sherman $M$ : ras transformation of simian virus 40-immortalized rat hepatocytes: an in vitro model of hepatocarcinogenesis. Cancer. Res. 1992; 52: 173-180:

283. Ison $\mathrm{HC}$, Woodworth $\mathrm{CD}$, Meng $\mathrm{Y}$, Kreider J, Miller T, Mengel L: Introduction of the ras oncogene transforms a simian virus 40 -immortalized hepatocyte cell line without loss of expression of albumin and other liver-specific genes. Cancer. Res. 1992; 52: 940-948.

284. Stevenson M, Volsky DI: Activated w-myc and w-ras oncogenes do not transform normal human lymphocytes. Mol. Cell. Biol. 1986; 6: 3410-3417.

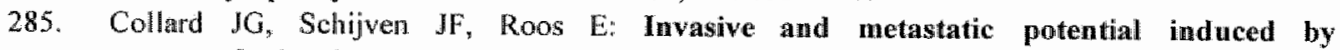
ras-transfection into mouse BW5147 T-lymphoma cells. Cancer. Res. 1987; 47: 754-759.

286. Nasi S, Sirinian MI, Panetta G, Marchetti $A_{x}$ Jucker R: Induction of the neoplastic phenotype of EBV-established B lymphocytes by the human Ha-ras oncogene. Oncogene. 1990; 5 : $117-122$.

287. Seremetis $S$, Inghirami $\mathrm{G}$. Ferrero $\mathrm{D}$, et $\alpha$ : Transformation and plasmacytoid differentiation of EBV-infected human B lymphoblasts by ras oncogenes. Science. $1989 ; 243 ; 660-663$.

288. Nakagawa $T$, Mabry $M$, de-Bustros $A$, thle $\mathrm{NN}$, Nelkin BD, Baylin $\mathrm{SB}$ : Introduction of $v$-Ha-ras oncogene induces differentiation of cultured human medullary thyroid carcinoma cells. Proc. Natll. Acad. Sci. U. S. A. 1987; 84: 5923-5927.

289. Noda $M$, Ko $M$, Ogura $A$, ef al: Sareoma viruses carrying ras oncogenes induce differentiation-associated properties in a neuronal cell line. Nature. 1985; 318: 73-75.

290. Mabry M, Nakagawa T, Baylin S, Pettengill $O$, Sorenson $G$, Nelkin B: Insertion of the c-Ha-ras oncogene induces differentiation of calcitonin-producing human small cell lung cancer. J. Clin Invest. 1989;84: 194-199.

291. Benito M, Porras A. Nebreda AR, Santos E. Differentiation of 3T3-L1 fibroblasts to adipocytes induced by transfection of ras oncogenes. Science. 1991; 253:565-568.

292. Baisch $H$, Collard $J, Z y w i e t z F$, Jung $H$ : No acquisition of metastatic capacity of R1H rhabdomyosarcoma upon transfection with c-Ha-ras oncogene. Invasion. Metastasis. 1990; $10: 193-207$. 
293. Price JE, Aukerman SL, Ananthaswamy HN, et at: Metastatic potential of cloned murine melanoma cells transfected with activated c-Ha-ras. Cancer. Res. 1989; 49:4274-4281.

294. Tuck $A B$, Wilson $S M$, Chambers $A F$ : ras transfection and expression does not induce progression from tumorigenicity to metastatic ability in mouse LTA cells. Clin. Exp. Metastasis. 1990: 8: 417-431.

295. Forrester $K$, Almoguera $\mathbb{C}_{\mathrm{p}}$ Han $K$, Grizzle WE, Pencho $M$ : Detection of high incidence of K-ras oncogenes during human colon tumorigenesis. Nature. $1987 ; 327 ; 298-303$.

296. Farr CJ, Marshall CJ, Easty DJ, Wright NA, Powell SC, Paraskeva SC: A study of ras gene mutations in colonic adlenomas from familiall polyposis coli patients. Oncogene. 1988,3 : 673-678.

297. Vogeistein B, Fearon ER, Hamilton SR, et al: Genetic alterations during colorectal-tumor development. N. Engl. J. Med. 1988; 319: 525-532.

298. Bos JL, Fearon ER, Hamilton SR, et al: Prevalence of ras gene mutations in human colorectal cancers. Nature. 1987; 327: 293-297.

299. Smit VT, Boot AJ, Smits AM, Eleuren GJ, Cornelisse CJ, Bos JL: KRAS codon 12 mutations occur very frequently in pancreatic adenocarcinomas. Nucleic. Acids. Res. 1988; 16 : $7773-7782$.

300. Losi L, Benhattar J, Costa J: Stability of K-ras mutations throughout the natural history of human colorectal cancer. Eur. J. Cancer. 1992;28A: 1115-1120.

301. Suchy B, Zietz C, Rabes HM: K-ras point mutations in human colorectal carcinomas: relation to aneuploidy and metastasis. Int. J. Cancer. 1992;52:30-33.

302. Daar 1, Nebreda AR, Yew $\mathrm{N}$, et al: The ras oncoprotein and M-phase activity. Science. 1991: $253: 74-76$.

303. Nebreda AR, Porras A, Santos E: p21Ras-induced meiotic maturation of Xenopus oocytes in the absence of protein synthesis: MPF activation is preceded by activation of MAP and S6 kinases. Oncogene. 1993; 8: 467-477.

304. Gallick GE, Kurzrock R, Kloetzer WS, Arlinghaus RB, Gutterman JU: Expression of p21 ras in fresh primary and metastatic human colorectal tumors. Proc. Natl. Acad. Sci. U. S. A. $1985 ; 82: 1795-1799$.

305. De-Biasi F, Del-Sal $G$, Hand PH: Evidence of enhancement of the ras oncogene protein product (p21) in a spectrum of human tumors. Int. J. Cancer. 1989; 43: 431-435.

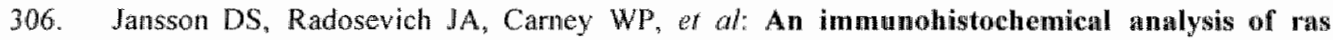
oncogene expression in epithelial neoplasms of the colon. Cancer. 1990; 65: 1329-1337. 


\section{CHAPTER 2}

\section{BEHAVIOR OF ORTHOTOPIC HUMAN COLORECTAL CARCINOMA XENOGRAFTS IN RELATION TO IN VITRO INVASION}

J.E. de Vries, W.N.M. Dinjens, H.W. Verspaget, E.P.M. van der Linden, A.P. de Bruine, M.M. Mareel, F.T. Bosman, and J. ten Kate.

Manuscript submitted for publication. 


\subsection{INTRODUCTION}

The mechanisms underlying tumor metastasis formation have been intensively studied in the past decade (1-4). Metastasis appears to be a multistep process but it is not yet clear which steps in the cascade of events ultimately determine whether or not a metastasis will occur. In any case invasion, defined as the ability of carcinoma cells to traverse the basement membrane (BM), detach from the primary tumor, and migrate into the extracellular matrix $(\mathbb{E C M})$, is an important step. Various in vitro models have been developed to study invasion (5), including invasion of tumor cells into embryonic chick heart fragments (6).

In wivo models more closely resemble the human situation than in vitro models and allow the study not only of invasion, but also of the further steps involved in metastasis formation. In general terms, two different approaches have been used in in vivo studies. The most frequent one is intravascular injection of cancer cells, which then lodge in and potentially grow out into a capillary bed along the circulation. In this approach only the final steps in metastasis formation can be studied. The more tedious and time consuming approach is the establishment of a primary xenograft, from which then spontaneous metastases might occur. In such a model, all steps of the metastatic cascade might be studied.

For reasons of convenience, subcutaneous inoculation has been most frequently used for xenografting. Subcutaneous xenografts, however, rarely metastasize. Following the ideas put forward by Fidler and Hart (7-9) concerning the influence of the microenvironment of a tumor xenograft on its tendency to metastasize, orthotopic xenografting has been adopted. From orthotopic sites spontaneous metastases more readily develop. We and others designed a model in which human colon cancer cell lines are xenografted orthotopically in the wall of the cecum of nude mice $(10,11)$. In this model, the obtained primary xenografts spontaneously give rise to lymph node, liver and lung metastases. This observation suggests that local tissue factors might play a role in the activation or inactivation of genes, of which the products are necessary for the development of metastases.

Of the proteins, potentially involved in invasion and metastasis, two categories have been extensively investigated. Proteases, responsible for dissolution of the basement membrane and the surrounding interstitial stroma, deserve to be mentioned. It has been shown that, depending on the experimental conditions and on the cell type under investigation, the expression of proteases such as urokinase plasminogen activator (u$\mathrm{PA}$ ) and type IV collagenase, is upregulated in invading and metastasizing cells (12-16). Cell-adhesion molecules have been studied, following the concept that as long as tumor cells remain integrated in a tissue structure, they will not dislodge and therefore not invade surrounding tissue and metastasize. Compelling experimental evidence in favor of such a role for E-cadherin has been provided by Behrens et al. (17) and Vleminckx et al. (18). Integrins, a fairly recently discovered family of cell-cell and cell-matrix adhesion molecules, might be expected to play a similar role in invasion and metastasis, 
particularly in the migration of invasive cells through the extracellular matrix and the lodging of tumor cells at distant sites in the microcirculation (reviewed in 19).

For the study of invasion and metastasis in colorectal cancer, orthotopic xenograft models have been developed, but a limited number of cell lines has been studied (10, $11,20-22)$. We xenografted a series of 9 colorectal carcinoma cell lines in the subcutis and in the cecum of nude mice in order to establish which of these cell lines would show tumorigenicity, local invasion and metastasis formation from either site. In a selected subset of cell lines we furthermore studied invasion in vitro (into chick heart embryonic heart fragments), in vitro production of the proteases U-PA and t-PA, Ecadherin expression in vitro and in vivo, and in vitro expression of $\alpha_{2} \beta_{1}, \alpha_{3} \beta_{1}$, and $\alpha_{6} B_{1}$ integrin receptors. Our results fit the hypothesis that the capacity of neoplastic cells to invade and metastasize is not only determined by the inherent characteristics of the cancer cells but is also modulated by the local microenvironment.

\subsection{MATERIALS AND METHODS}

\subsubsection{Cell culture}

The following human colorectal cancer cell lines were used: CaCo 2 (23), SW1116, SW480, SW620 (24), NCI-H716 (25), LS174T (26), 5583E, 5583S (27), HT29 (28). The cells were maintained in Dulbecco's Modified Eagle's Medium supplemented with $10 \%$ Fetal Calf Serum.

\subsubsection{Xenografting}

Athymic CD-1 male nude mice, 3-4 weeks old, were obtained from Charles River Wiga (Freiburg, Germany) and maintained in a laminar air flow cabinet under specific pathogen free conditions.

Tumor cells were harvested with $0.1 \mathrm{~g}$ trypsin, $0.02 \mathrm{~g}$ EDTA per $100 \mathrm{ml}$ PBS, washed and diluted in sterile PBS to a density of $1 \times 10^{7} / \mathrm{ml}$. Nude mice under ether anesthesia were injected with $1 \times 10^{6}$ tumor cells in the subcutis, the spleen or the cecal wall, which was approached through a small median abdominal incision. Then, the tumor cells were injected along the mesocolon using a $30 \mathrm{G}$ needle. The abdomen was subsequently closed in two layers (11). Liver colonizing ability was determined by inoculation of tumor cells into the spleen (20). The spleen was exposed through a small incision in the skin and peritoneum, and tumor cells were injected subcapsularly. The spleen was repositioned and the incision was sutured. The mice were sacrificed after 7 weeks. of all mice, at autopsy the tumor at the site of injection as well as the liver, lungs and lymph nodes were collected, in order to detect the presence of metastases macroscopically as well as microscopically. Tissues were fixed in $4 \%$ formalin, embedded in paraplast for histology and for immunohistochemical staining. At least three nonconsecutive sections were examined when there was no macroscopic evidence of metastasis. 


\subsubsection{Invasion into embryonic chick heart fragments}

Briefly, cells growing in suspension were harvested by centrifugation and cells growing in a monolayer by scraping with a rubber policeman. The cells were brought into contact with precultured 9-day-old embryonic chick heart fragments on top of a semisolid agar medium. After incubation overnight $\left(37^{\circ} \mathrm{C}\right)$, individual confronting pairs were put into $5 \mathrm{ml}$. Erlenmeyer flasks with $1.5 \mathrm{ml}$. of liquid culture medium on a gyrotory shaker and further incubated $\left(120 \mathrm{rpm}, 37^{\circ} \mathrm{C}\right)$. The confronting pairs were fixed, embedded in paraffin and sectioned for microscopy after 4 and 7 days. Invasiveness was determined and scored as described previously (5).

\subsubsection{Quantitation of u-PA and t-PA}

When the cells in stock culture had almost reached confluency, the medium was changed and after $24 \mathrm{~h}$, the supernatant harvested, centrifuged and directly stored at $70^{\circ} \mathrm{C}$ until further analysis.

Cells growing in suspension were harvested by centrifugation and washed twice. Cells growing in a monolayer were rinsed twice with PBS and harvested by scraping with a rubber policeman. Cell pellets were lysed in $1 \mathrm{ml} \mathrm{PBS} / 0.5 \%$ Triton X-100 and stored at $-70^{\circ} \mathrm{C}$ until further analysis. U-PA and t-PA were measured by sandwich ELISA as described previously $(29,30)$. Protein content of the cell extracts was determined according to Lowry et al. (31). The intra- and intersample variation did not exceed $3 \%$ and $10 \%$ respectively.

\subsubsection{Immunohistochemistry}

\section{E-cadherin}

After trypsinization of a monolayer culture, the solitary cells were seeded on glass coverslips in a 24 well plate. Two to 3 days after incubation the coverslips containing the cells were washed briefly in PBS containing $\mathrm{Ca}^{2+}$ and $\mathrm{Mg}^{2+}$ and fixed in methanol at $-25^{\circ} \mathrm{C}$ for $15 \mathrm{~min}$, air dried and stored at $-25^{\circ} \mathrm{C}$ until use.

Fixed cell cultures were taken from frozen stock and brought to room temperature. They were rehydrated in Tris buffered saline $\mathrm{pH}=7.6$ (TBS) and incubated in 5\% BSA in TBS for $30 \mathrm{~min}$. Then a mixture of primary antibodies composed of a monoclonal mouse antibody against human E-cadherin (HECD-1 (British Biotechnology Products LTd, Abingdon, UK), diluted I:100 in TBS) and a polyclonal rabbit antibody against keratin (PKE (Euro-Diagnostica, Apeldoorn, The Netherlands), diluted 1:50) was added for 1 h. After 3 subsequent washings, a mixture of secondary antibodies composed of ShAM conjugated with biotin (Amersham, UK), diluted 1:50 in TBS, and GAR conjugated to FITC (Nordic, Tilburg, The Netherlands), diluted 1:20, was added for 1 h. A final incubation was done in Streptavidin linked to Texas red (Amersham, UK), diluted 1:50 in TBS, and DAPI (4',6'-diamidino-2-phenyl-indole (Sigma, St. Louis, MO, USA), $0.4 \mu \mathrm{g} / \mathrm{ml}$ in TBS, for $15 \mathrm{~min}$. After thorough rinsing the coverslips were mounted in Glycergel (DAKO, Glostrup, Denmark). Photographs were taken with a Leitz-Dialux 20 photomicroscope equipped for epifluorescence. 
Xenografted tumor tissue specimens were formalin fixed $(3 \mathrm{~h}, \mathrm{RT})$ and paraffin embedded. Sections were mounted on glass slides and dehydrated. Endogenous peroxidase was blocked by incubation in PBS/0.3\% with $\mathrm{H}_{2} \mathrm{O}_{2}(20 \mathrm{~min}$, RT), The slides were incubated with the primary antibody and, after washing with PBS, incubated with rabbit anti-mouse horseradish peroxidase conjugate (DAKO, P260, Glostrup, Denmark). Peroxidase activity was visualized with diaminobenzidine and the slides were counterstained with hematoxylin.

\section{Integrins}

Cells were harvested by gentle scraping with a rubber policeman, washed twice with PBS, diluted in PBS $/ 1 \%$ BSA and centrifuged on a glass slide. Methanol $\left(1 \mathrm{~min},-20^{\circ} \mathrm{C}\right.$ ) followed by acetone $\left(3 \times 1 \mathrm{sec},-20^{\circ} \mathrm{C}\right)$ was used for fixation of the cells. Monoclonal antibodies $10 \mathrm{GH}$, specific for the $\alpha_{2} B_{1}$ integrin (32) and GoH3, specific for the $\alpha_{6}$ chain (33) were generous gifts from Dr. A. Sonnenberg, the monoclonal antibody $I / 43$ directed against the $\alpha_{3}$ chain was a kind gift from Dr. A. P. Albino (34). Integrin chains were detected as described for E-cadherin in xenografts.

As negative controls, specific antibodies were omitted and normal human colon mucosa was used as a positive control. Immunohistochemical results were scored independently by two observers (JdV, ExdL), providing largely concordant results.

\section{$2.3 \quad$ RESULTS}

\section{In vivo behavior of human colorectal carcinoma cell lines}

The take rate of human colorectal carcinoma cell lines xenografted in the subcutis of nude mice was $100 \%$, except for $\mathrm{CaCo} 2$ cells, which under standard xenografting conditions did not produce tumors (Table 1). All cell lines grew expansively in the subcutis, with a rim of fibrous tissue surrounding the tumor in SW1116, SW480, SW620, LS174T and 5583E xenografts. Invasion into surrounding tissue was observed for NCI-H716,5583S, and HT29. After grafting in the subcutis, none of the tumor cell lines gave rise to metastatic lesions.

Orthotopic xenografting of the colorectal carcinoma cell lines in the wall of the cecum yielded in general lower take rates varying between $25 \%$ (NCl-H716 and SW1116) and $100 \%$ (LS174T and 5583E) with the exception of CaCo 2 cells, which did not produce tumors. SW1116, SW480 and SW620 showed tumor growth in solid nodules in the subserosa without invasion of the bowel wall (Fig. 1) or the development of metastases. NCl-H716 and LS174T cells developed primary tumors with irregular nests and strands of cells, invading the muscularis propria and mucosa. Metastases, however, were not observed (Table 1). HT29, 5583E and 5583S xenografts showed an inwasive growth pattern but also gave rise to lymph node metastases and microscopic metastases in the lungs and in the liver. The metastases extended from small arteries in the lungs or venules in the portal triads in the liver (Fig. 1). 
Table 1 . In wwo behavior of buman colorectal cancer cell lines.

\begin{tabular}{|c|c|c|c|c|c|}
\hline Cell line & Subcutis & $\begin{array}{l}\text { Cecum } \\
\text { primary }\end{array}$ & invasive & metastasis & Spleen \\
\hline $\mathrm{CaCo}_{2}$ & 0.5 & $0 / 5$ & $0 / 5$ & $0 / 5$ & $\mathrm{NT}^{2}$ \\
\hline $8 w 1116$ & $5 / 5$ & $1 / 4$ & $0 / 1$ & $0 / 1$ & $1 / 4$ \\
\hline SW W 480 & $10 / 11$ & $3 / 5$ & $0 / 3$ & $0 / 3$ & $3 / 4$ \\
\hline SW620 & $7 / 8$ & 819 & $0 / 8$ & $0 / 8$ & $N T$ \\
\hline $\mathrm{NCI} H \mathrm{H} 16$ & $24 / 26$ & $1 / 4$ & $1 / 1$ & $0 / 1$ & $N T$ \\
\hline LS174T & $4 / 4$ & $7 / 7$ & $7 / 7$ & $0 / 7$ & $3 / 3$ \\
\hline $5583 E$ & $5 / 5$ & $5 / 5$ & $1 / 5$ & 1/1 (lung) & $2 / 3$ \\
\hline $5583 \mathrm{~S}$ & $\$ / 5$ & $6 / 10$ & $3 / 6$ & $1 / 3$ (liver) & $3 / 8$ \\
\hline HT29 & $5 / 5$ & $4 / 5$ & $4 / 4$ & $3 / 4$ (lung) & $\mathrm{NT}$ \\
\hline
\end{tabular}

1. Number of primary tumors per number of inoculations of tumor cells into the wall of the cecum.

2. Invasive if tumor cells were observed in the muscularis mucosa or adjacent to colon crypt cells.

3. NT $=$ not tested.

Table 2. Parameters of human colorectal cancer cell lines.

\begin{tabular}{|c|c|c|c|c|c|c|c|c|c|}
\hline \multirow[t]{2}{*}{ Cell line } & \multirow[t]{2}{*}{$\mathrm{ECHF}$} & \multirow{2}{*}{$\begin{array}{l}\mathrm{u}-\mathrm{PA}^{2} \\
\text { medium }\end{array}$} & \multirow[b]{2}{*}{$\operatorname{cell}^{4}$} & \multirow{2}{*}{$\begin{array}{l}\mathrm{L-PA} \\
\mathrm{cell}\end{array}$} & \multicolumn{2}{|c|}{ E-Cadherin } & \multicolumn{2}{|c|}{ Intregrins } & \multirow[b]{2}{*}{$\alpha_{6} B_{i}$} \\
\hline & & & & & in vitro & in wivo & $\alpha_{2} \beta_{1}$ & $\alpha_{3} B_{1}$ & \\
\hline $\operatorname{CaCo} 2$ & -1 & 1332 & 37 & 579 & $\mathrm{Hmg}^{5}$ & $\mathrm{NT}$ & $\pm^{6}$ & - & 4 \\
\hline $5 W 620$ & + & 22850 & 161 & 498 & Htr & - & \pm & - & $+1+1$ \\
\hline $\mathrm{LS} \| 74 \mathrm{~T}$ & - & 540 & 17 & 388 & $\mathrm{Hmg}$ & - & + & - & +1 \\
\hline HT29 & - & 1308 & 240 & 269 & Hing & $\mathrm{Her}$ & $+H+$ & $t+$ & $+1+t$ \\
\hline
\end{tabular}

1. Invasion into embryonic chick heart fragments: - $=$ not invasive, $t=$ invasive.

2. Mean values obtained in two independent experiments; 3 . Pg/ml medium; 4. Pg per mg protein.

5. Hmg $=$ honogenous expression; Htr $=$ heterogenous expression; NT $=$ not tested for lack of tissue.

6. Percentage positive cells: $-=0 \% ; \leq 1 \% ;+=1 \%-10 \% ;++=10 \%-75 \% ;+t+=>75 \%$ positive cells.

Intrasplenic injection of colorectal carcinoma cell lines, either non-metastatic or metastatic after grafting in the cecum, demonstrated that both categories of tumor cells were able to colonize the liver (Table 1). The take rate varied, being $25 \%$ for SW 1116 and $100 \%$ for LS174T, and ranged between these values in SW480 and 5583 (E and S). For turther characterization we selected $\mathrm{CaCo} 2$ (poorly tumorigenic), SW620 (tumorigenic, non-invasive in the cecum), LS174T (tumorigenic, invasive in the cecum, non-metastatic), and HT29 cells (tumorigenic, invasive in the cecum and metastatic). 

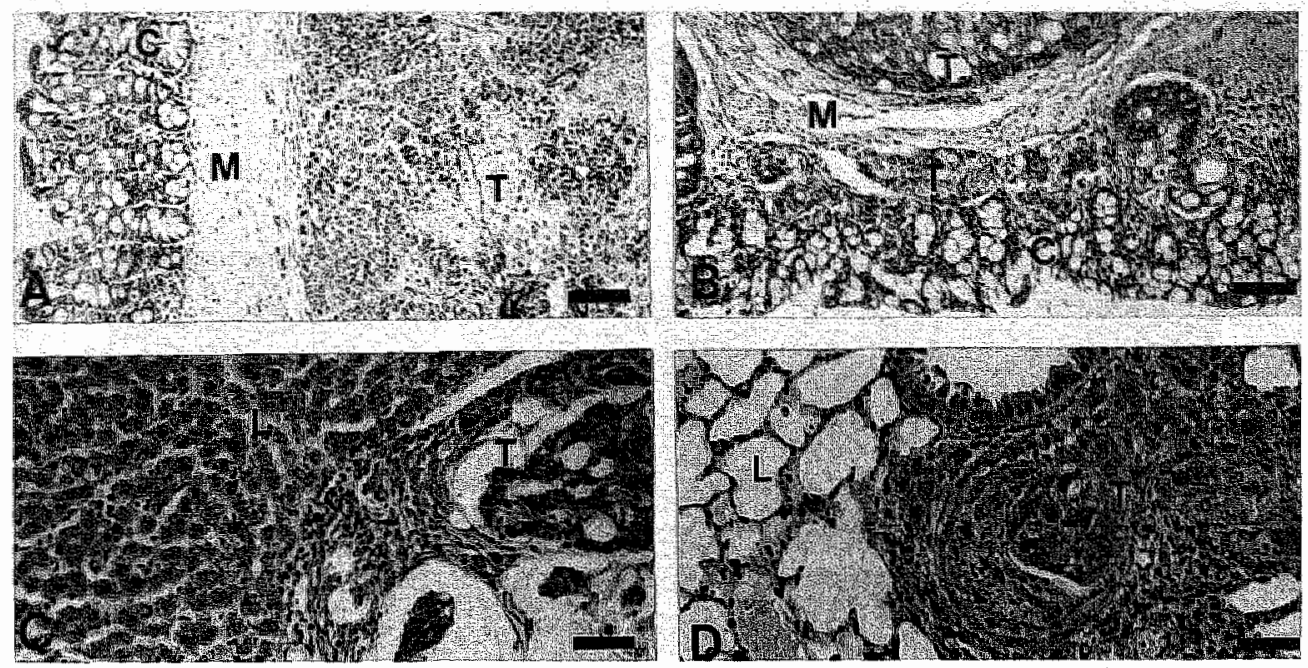

Figure 1. Growth behavior of collorectal cancer cell lines in vivo.

A. Behavior of SW620 cells in the cecum, the muscularis mucosa is not invaded by tumor cells. B. Behavior of HT29 cells in the cecum, tumor cells have migrated through the muscularis mucosa, adjacent to crypt cells of the colon. C. Metastatic lesion of $5583 \mathrm{~S}$ in the liwer. D. Metastatic lesion of HT29 in the lung. Bar is $20 \mu \mathrm{m}(A, B)$ and $10 \mu \mathrm{m}(C, D)$.

$\mathrm{T}=$ tumor cells; $\mathrm{M}=$ muscularis mucosa; $\mathrm{C}=\mathrm{crypt}$ cells of the colon; $\mathrm{L}=$ liver $(\mathrm{C})$ or lung $(\mathrm{D})$.

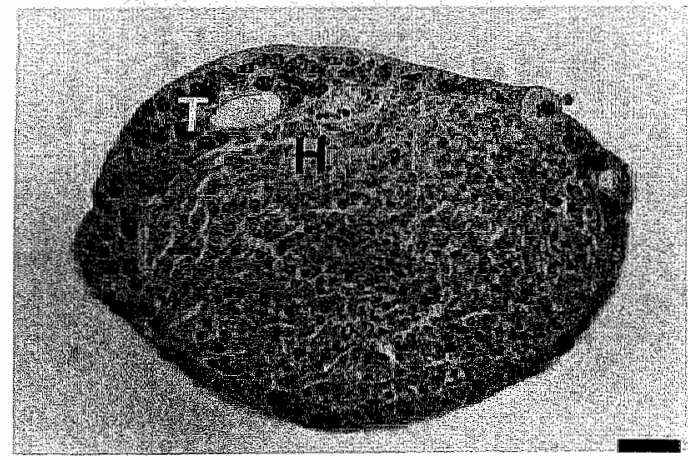

Figure 2. In vitro invasilon.

The colorectal cell line $\mathrm{CaCo} 2$ does not invade embryonic chick heart frogments after 7 days of coculture. Bar is $40 \mu \mathrm{m}$. $T^{\prime \prime}=$ tumor cells; $\mathrm{F}=$ Heart tissut.

\section{Invasion of embryonic chick heart fragments}

$\mathrm{CaCO} 2$ and $\mathrm{LS} 174 \mathrm{~T}$ cells did not demonstrate invasive behavior in this assay, whereas SW620 cells invaded into the myocardial tissue (Fig. 2, Table 2). HT29 cells could only 
be succesfully confronted with embryonic chick heart fragments on top of a semi-solid agar medium containing DMEM. In this approach HT29 cells did not invade into the myocardial insue.
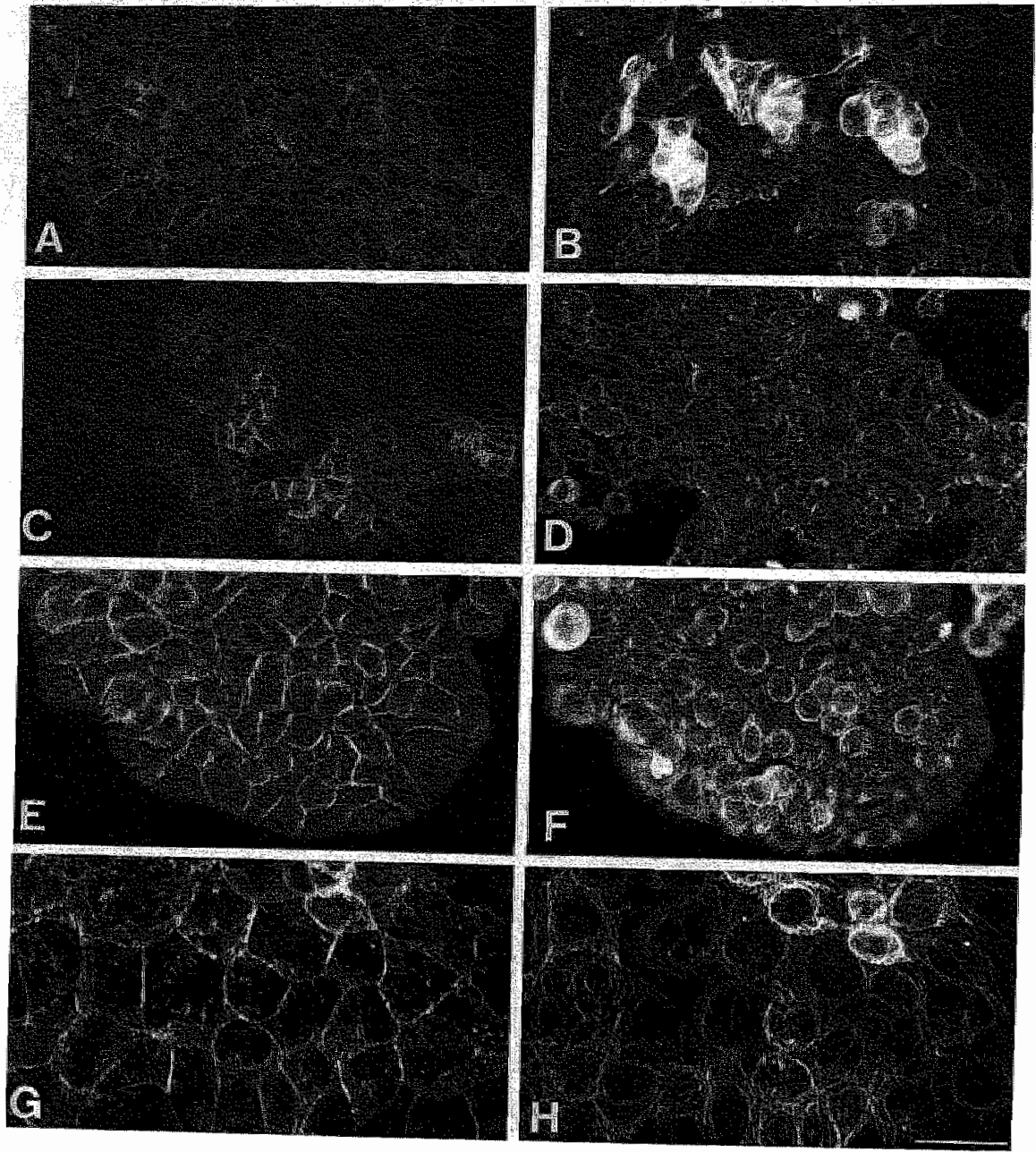

Figure 3. E-cadherin expression in vitro. Immunothorescence staining of E-cadherin $(\mathbf{A}, \mathbf{C}, \mathbf{E}, \mathbf{G})$ and keratin $(\mathbf{B}, \mathbf{D}, \mathbf{F}, \mathbf{H})$ of LS174T $(\mathbf{A}, \mathbf{B})$,
$\mathrm{SW620}(\mathbf{C}, \mathbf{D}), \mathrm{HT} 29(\mathbf{E}, \mathbf{F})$, and $\mathrm{CaCo} 2 \mathrm{cells}(\mathbf{G}, \mathbf{H})$. Scale bar $=50 \mu \mathrm{m}$. 


\section{Production of $u-P A$ and $t-P A$ in vitro}

The results of the U-PA and t-PA assays are listed in Table 2. By far the highest amount of $\mathrm{u}-\mathrm{PA}$ in the culture medium was found in SW620 cells. This was also the only cell line invasive in the embryonic chick heart assay. $\mathrm{CaCo} 2$ and $\mathrm{Hr}_{2} 9$ cells produced roughly equal amounts of u-PA while the lowest amount was secreted by LS174T cells. The release of $\mathrm{u}-\mathrm{PA}$ into the medium did not correlate with any of the features of in vivo growth. The amount of U-PA recovered from cell extracts was considerably lower than the amount of $\mathrm{u}-\mathrm{PA}$ recovered from the medium. Hardly any t-PA was found in the culture medium (data not shown). In cell extracts, all cell lines showed roughly equal amounts of t-PA (Table 2).

\section{Expression of E-cadherin}

The presence of cytokeratin filaments in all cell lines confirmed the epithelial origin of these cell lines, with the most highly structured filamentous pattern observed in $\mathrm{CaCO} 2$ cells. The cell lines $\mathrm{CaCo}$, LS174T, and HT29 demonstrated in vitro homogenous staining for $\mathbb{E}$-cadherin, which was membrane-associated. In contrast, $\mathrm{SW620}$ cells showed heterogenous staining: Membrane-associated immunoreactivity was observed only in multilayered cell clusters, whereas cells in a monolayer were negative (Fig. 3 , Table 2).

In vivo, E-cadherin expression could not be studied on $\mathrm{CaCo} 2$ cells. In cecal grafts of SW620 and LS174T cells E-cadherin expression was not detected (Fig. 4, Table 2). Heterogenous expression was observed in cecal grafts of the HT29 cell line. Membranous E-cadherin immunoreactivity was detected only focally in clusters of HT29 tumor cells with a more highly differentiated growth pattern (Fig. 4, Table 2).
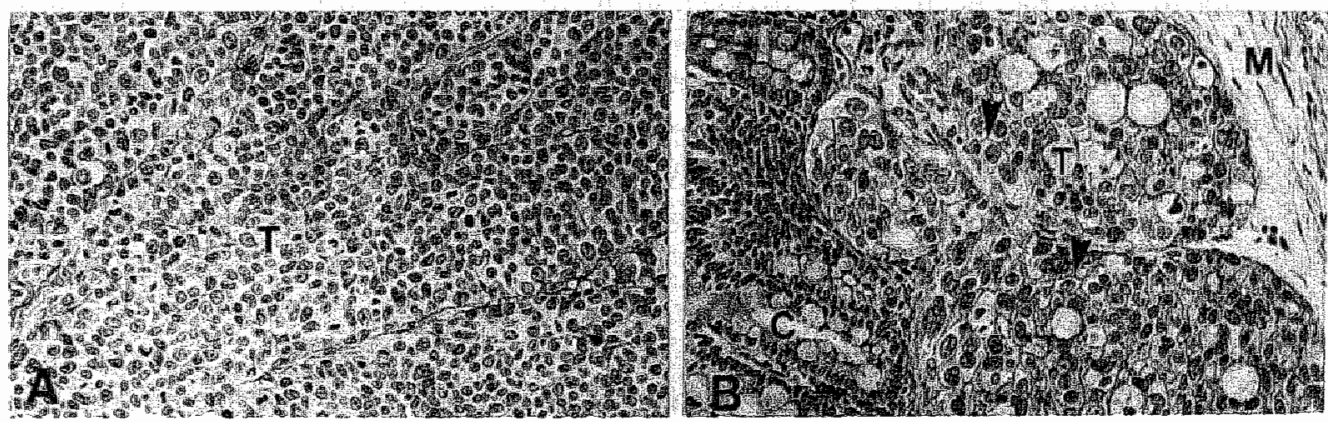

Figure 4. E-cadherin expression in wivo.

A. Cecal xenograft of $\$$ W620 cells. Note the lack of E-cadherin expression. B. Cecal xenograft of HT29 cells. Note E-cadherin staining at the membrane of tumor cells, indicated by arrows. Magnification $200 \mathrm{x}, T=$ tumor cells; $M=$ muscularis mucosa; $C=$ crypt cells of the colon. 


\section{Expression of integrin receptors in vitro}

As integrin receptors are only functional on the cell surface, only membrane staining was taken into account. High expression of $\alpha_{2} B_{1}$ and $\alpha_{3} B_{1}$ was restricted to HT29 cells, LSI74T cells only showing occasional weakly stained cells for $\alpha_{2} B_{1}$, whereas $\alpha_{3} B_{1}$ was not detected in the other cell lines at all. Expression of $\alpha_{6} B_{1}$ was detected on all cells (Fig. 5, Table 2). As integrins can be only stained on unfixed tissue, integrin expression was not assayed in the in vivo situation.
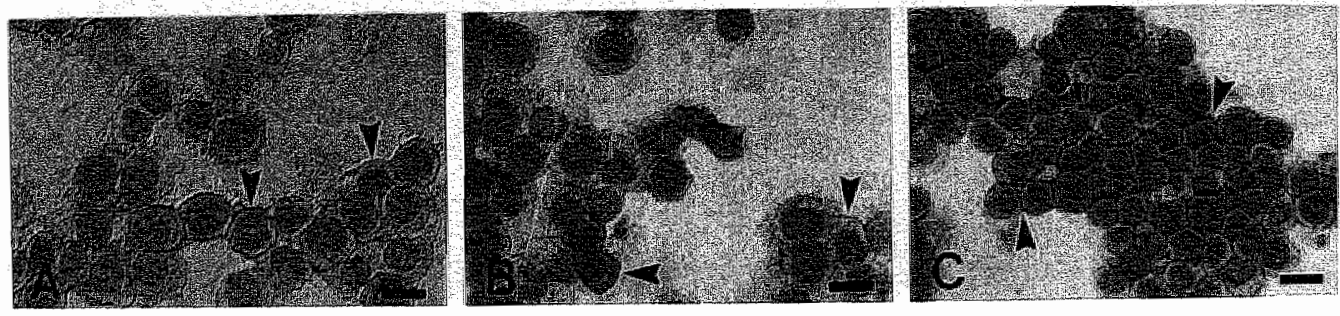

Figure 5 . Integrin receptor expression in vitro.

A. HT29 cells stained with an antibody specific for $\alpha_{2} B_{1}$. B. HT29 cells stained with an antibody specific for $\alpha_{3} \beta_{1}$. C. SW620 cells stained with an antibody specific for $\alpha_{6} \beta_{1}$. Arrows indicate cells with immunoreactivity for the antigen detected by the monoclonal antibody used. Note the heterogeneity in the intensity of expression in positive cells. Bar is $5 \mu \mathrm{m}$.

\subsection{DISCUSSION}

In order to study the mechanisms involved in the development of metastases, orthotopic nude mouse xenograft models have evolved in which the primary graft will spontaneously give rise to metastases. Earlier models, such as injection of tumor cells in the subcutis or intravenous injection of tumor cells, either do not give rise to metastases or only allow evaluation of late steps in the metastatic cascade. Following earlier reports (9-11) we have employed an in vivo model in which human colorectal carcinoma cells are xenografted orthotopically into the wall of the cecum of nu/nu mice. The major advantage of this model is that the entire metastatic cascade can be studied.

We initially studied the behavior of the cancer cells after subcutaneous inoculation in comparison with injection in the wall of the cecum. All cell lines, with the exception of $\mathrm{CaCo} 2$ cells which were non-tumorigenic, showed in the subcutis either non-invasive encapsulated growth or invasion into surrounding tissue, but metastases did not occur. In the cecum, the cell lines were either non-tumorigenic, tumorigenic but non-invasive, tumorigenic and invasive but non-metastatic or tumorigenic, invasive and metastatic. Also LS174T and 5583E cells, which were non-invasive in the subcutis, displayed 
invasive behavior in the wall of the cecum. Hematogenous metastases occurred in the liver as well as in the lungs.

The occurrence of lung metastases contrasts with the findings of Morikawa et al. (22) and of Bresalier et al. (10) who did not observe Jung metastases in similar studies. It is possible that in our but not in their experiments the cells entered the lymphatic circulation from the peritoneal cavity and then spread hematogenously to the lungs. Another possibility is that the tumor cells bypassed the liver via portocaval shunts.

The observation that all metastatic cell lines showed invasive primary tumors underlines that invasive ability is an essential prerequisite for the development of metastatic lesions. Lack of metastatic capacity after orthotopic xenografting was not due to the inability of tumor cells to grow at ectopic sites, because all cell lines, with the exception of $\mathrm{CaCo} 2$ cells, yielded primary tumors in the subcutis. Moreover, nonmetastatic SW1116, SW480 and LS174T cell lines were able to colonize the liver after intrasplenic injection. These observations indicate firstly that invasive capacity does not necessarily also implies metastatic capacity and secondly that cancer cells differ in the ability to invade and metastasize. A third conclusion is that the expression of the invasive and/or metastatic phenotype apparently can be modulated by local tissue factors.

We furthermore investigated in CaCo2, SW620, LS174T and HT29 cells whether or not in vivo behavior of the tumor cells correlated with specific in vitro characteristics. The capacity of colorectal carcinoma cells to invade embryonic chick heart fragments was not predictive for invasion in vivo. Although the non-tumorigenic $\mathrm{CaCo} 2$ cells were not invasive in this assay, LS174T and HT29 cells were invasive in vivo but not in vitro, whereas SW620 cells were invasive in vitro but not in vivo. This discrepancy may again be explained in terms of the modulating effects of cancer cell micro-environments on cancer cell behavior. Apparently tissue specific factors in the host may either induce or inhibit the invasive phenotype (35).

A role for $\mathrm{u}-\mathrm{PA}$ or $\mathrm{t}-\mathrm{PA}$ in invasion has been postulated because of their involvement in the breakdown of the extracellular matrix, which is essential for carcinoma cells to invade surrounding stroma $(3,36-40)$. Indeed, a high level of $\mathrm{u}-\mathrm{PA}$ production by SW620 cells in stock-culture was found together with invasion into embryonic chick heart fragments. However, neither the cellular content nor the release of U-PA and t-PA into the medium of stock cultured cells correlated with in vivo invasive behavior. This was reported also for a panel of breast carcinoma cell lines (41). "These observations do certainly not exclude a role for U-PA or I-PA in invasion, because the enzymatic activity of these plasminogen activators is not only determined by the amount of enzyme available but is also subject to several regulating mechanisms, which include specific activators, inhibitors and receptors (42-45).

In our experiments E-cadherin expression was observed in vitro in all cell lines. However, the CaCo 2, LS174T, and HT29 cell lines demonstrated in vitro homogenous expression of E-cadherin, whereas it was heterogenous in SW620. Only the latter showed invasive behavior in the embryonic chick heart fragment assay. E-cadherin 
immunoreactivity in vivo was not observed in xenografts of SW620 and LS174T, and was heterogenous in xenografts of HT29. This suggests downmodulation of E-cadherin expression in vivo (46) and demonstrates that the microenvironment in which the cells reside (medium vs. tissue) modulates E-cadherin expression. Furthermore, invasive behavior in vitro thus appears to be correlated with heterogenous expression of $\mathrm{E}$ cadherin in vitro. The fact that in vivo SW620 cells are not invasive, while negative for E-cadherin, suggests that additional factors must be involved to acquire invasive capacity, as has been mentioned before by Mareel et al. (47). Therefore, the relationship between E-cadherin expression and invasion in vivo is complex. This is demonstrated by immunohistochemical studies of primary human colon carcinomas, where E-cadherin expression correlates strongly with the differentiation grade of the tumor but less obviously with invasive and metastatic potential $(48,49)$.

The expression of $\alpha_{2} \beta_{1}$ and $\alpha_{3} B_{1}$ integrin, which bind a.o. laminin and type IV collagen (50), was high in the in vivo metastatic HT29 cells, in agreement with Schreiner et al. (51). It has been reported previously that the metastatic potential of rhabdomyosarcoma cells increased after transfection with cDNA coding for the $\alpha_{2}$ integrin subunit (52). This finding may be explained in terms of a mediating role for integrin receptors in the migration of the cancer cell through the extracellular matrix and in the adhesion of circulating cancer cells to a potential metastatic site.

We conclude that; 1. Homogenous expression of E-cadherin in vitro and low production of U-PA in vitro correlate with non-invasive behavior in vitro, whereas cell lines invasive in vivo show heterogenous or absence of E-cadherin expression; 2 . Invasive behavior in vitro does not necessarily go along with invasion and metastasis in vivo; 3 . Invasion in vivo is not associated with $\mathrm{u}-\mathrm{Pa}$ and $\mathrm{t}$-PA production in vitro, E-cadherin expression in vitro as well as in vivo, and expression of the $\alpha_{3} \beta_{1}$ and $\alpha_{6} \beta_{1}$ integrin receptors, but seems to associated with $\alpha_{2} \beta_{1}$ integrin receptors; 4 . Local tissue factors may play a role in the induction of the expression of the genes responsible for invasion and metastasis, which is exemplified by the different expression of E-cadherin in vitro compared with the expression of E-cadherin in vivo. These results suggest that the microenvironment in which cancer cells grow is one of the factors involved in the regulation of invasive and melastatic behavior. 


\subsection{REFERENCES}

1. Poste G, Fidler IJ: The pathogenesis of cancer metastasis, Nature. 1980;283: 139-146.

2. Liotta LA: Tumor invasion and metastases: role of the basement membranc. Warner-Lambert Parke-Davis Award lecture. Am. J. Pathol. 1984; 117:339.348.

3. Liotta LA, Steeg PS, Stetler-Stevenson WG: Cancer metastusis and angiogenesis: an imbalance of positive and negative regulation. Cell. 1991; 64:327-336.

4. van Roy F, Mareel M: Tumour invasion: effects of cell adhesion and motility. Trends in Cell Biology 1992; 2: 163-169.

5. Mareel MM, Van-Roy FM, Messiaen LM, Boghaert ER, Bruyneel EA: Qualitative and quantitative analysis of tumour invasion in vivo and in vitro. $\mathbb{J}$. Cell. Sci. Suppl. 1987; 8 : $141-163$.

6. Mareel $M$, Kint J, Meyvisch $C$ : Methods of study of the invasion of malignant C3H-mouse fibroblasts into embryonic chick heart in vitro. Virchows Arch. B Cell Patli, 1979; 30 : 95-111.

7. Hart IR: 'Seed and soil' revisited: Mechanisms of site-specific metastasis. Cancer. Metastasis. Rev. 1982; 1: 5-17.

8. Fidler II: Rationale and methods for the use of nude nice to study the biology and therapy of human cancer metastasis. Cancer. Metastasis. Rev. 1986; $5: 29-49$.

9. Fidler II, Naito S, Pathak S: Orthotopic implantation is essentiall for the selection, growth and metastasis of human renal cell cancer in nude mice. Cancer. Metastasis. Rev. 1990; 9 : $149-165$.

10. Bresalier RS, Raper SE, Hujanen ES, Kim YS: A new animal model for human colon cancer metastasis. Int. J. Cancer. 1987; 39:625-630.

11. Sekikawa $\mathrm{K}$, Arends JW, Verstijnen $\mathrm{CP}$, et al: Influence of implantation site on growth, antigen expression and metastatic potential of human colomic cancer HT29 and 5583 xenografts in nude mice. Invasion. Metastasis. 1988; $8: 238-252$.

12. Cajot $3 \mathrm{~F}$, Sordat $\mathrm{B}$, Bachmann $\mathrm{F}^{*}$ : Human primary colon carcinomas xenografted intio nude mice. II. Modulation of tumor plasminogen activator activity by the host tissue environment. J. Natl. Cancer. Inst. 1986; 77: 1099-1107.

13. Turpeenniemi-Hujanen T, Thorgeirsson UP, Hart IR, Grant SS, Liotta LA: Expression of collagenase IV (basement menbrane collagenase) actiwity in murine rumor cell hybrids that differ in metastatic potential. I. Natl. Cancer. Inst. 1985; 75:99-103.

14. Greig RG, Koestler TP, Trainer $\mathrm{DL}$, et af: Tumorigenic and melastatic properties of "normal" and ras-transfected NIH/3T3 cells. Proc. Natl. Acad. Sci. U. S. A. 1985; 82: 3698-3701.

15. Ura $\mathrm{H}$, Bonfil RD, Reich $\mathrm{R}$, ef al: Expression of type IV collagenase and procollagen geness and its correlation with the tumorigenic, invasive, and metastatic abilities of oncogene-transformed human bronchial epithelial cells. Cancer. Res. $\|989 ; 49: 4615-462\|$.

16. Quax PHA, van Muijen GNP, Weening-Verhoeff EJD, et al: Metastatic beliavior of human melanoma cell lines in nude mice correlates with urokinase-type plasminogen activator, its type-1 inhibitor, and urokinase mediated matrix degradation. J. Cell. Biol. 1991; 115: $191-199$.

17. Behrens J, Mareel MM, Van-Roy FM, Birchmeier W: Dissecting tumor cell invasion: epithelial cells acquire invasive properties after the loss of uvomorulin-mediated cell-cell adhesion. J. Cell. Biol. 1989; 108: 2435-2447. 
18. Veminckx $K$, Vakaet $L$ J. Mareel $M$. Fiers $W$, vani-Roy $F$. Genetic manipulation of E-cadherin expression by epithellall momor cells reveals an invasion suppressor rolle. Cell. $1991 ; 66: 107-119$

19. Albelda $\mathrm{sM}$ Role of integrins and other cell adhesion molecules in tumour progression and metastasis. Lab. Invest. 1993; 68:4-17.

20. Giawazi R, Jessup AM, Campbell DE, Walker SM, Fidler U: Experimental nude mouse model of human colomectal cancer liver metastasis. J. Natl. Cancer. Inst. 1986; 77 : $1303-1308$.

21. Morikawa $K$, Walker $S M$, Jessup IM, Fidher $U$ : In vivo selection of highly metastatic cells from surgical specinens of different primary human colon carcinomas implanted into wide mice. Cancer. Res. 1988; 48:1943-1948.

22. Morikawa $K$, Walker $S M$, Nakaima M, Pathak $S$, Jessup JM, Fidler IJ: Influence of organ environment on the growth, selection, and metastasis of human colon carcinoma cells in nude mice. Cancer. Res. 1988; 48: 6863-6871.

23. Fogh $J$, Fogh $J M$, Orfeo $T$ : One hundred and twenty-seven cultured human tumor cell lines producing tumors in nude mice, I. Natl. Cancer. Inst. 1977; 59:221-225.

24. Leibovitz A, Stinson JC, McCombs WB, et al. Classification of human colorectal adenocarcinoma cell lines. Cancer Research $1976 ; 36: 4562-4569$.

25. Park J-G, Oie HK, Sugarbaker $\mathrm{PH}$, et al Characteristics of cell lines established from human colorectal carcinoma. Cancer. Res. 1987; 47: 6710-6718.

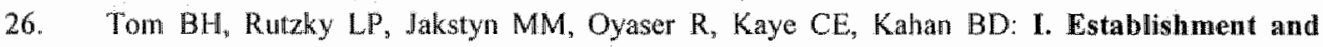
description of a new line. In Vitro 1976; 12:180-191.

27. Verstijnen CPHJ, Arends $J W$, Moerkerk PTM, Geraedts JPM, Uitendaal MP, Bosman FT: Two new colonic carcinoma cell lines derived from one human colonic adenocancinoma: establishmemt and characterization. Virchows Arch. B Cell Path. 1987; 53: 191-197.

28. Fogh J, Trempe G: New human tumor cell lines. New York: Plenum Publishing Corp., 1975

29. Bimema DJ, van lersel $J J L$, Dooijeward $G$ : Quantitation of urokinase antigen in plasma and culture media by use of an ELISA. Thromb. Res. 1986; 43: $569-577$.

30. Rijken DC, van Hinsbergh VWM, Sens EHC: Quantitation of tissue-type plasminogen activator in human endothelial cell cultures by use of an enzyme immunoassay. Thromb. Res. 1984; $33: 145 \times 153$.

31. Lowry $\mathrm{OH}$, Rosebrough NJ, Farr $\mathrm{AL}$, Randall $\mathrm{RJ}$ : Protein measurement with the Folin phenol reagent. J. Biol. Chem. 1951; 193:265-275.

32. Gitay JC, Brinkman HJ, Modderman PW, von-den-Bome AE, van-Mourik JA: Human vascular endothelial cells express a membrane protein complex inmunochemically Indistinguishable from the platelet VLA-2 (glycoprotein Ia-IIa) complex. Blood. 1989: 73: 1235-124!.

33. Sonnenberg A, Hogervorst $\mathbb{F}$, Osterop A, Veltman FE: Identification and characterization of a novel antigen complex on mouse mammary tumor cells using a monoclonal antibody against platelet glycoprotein Ic. J. Biol. Chem. 1988; 263: 14030-14038.

34. Fradet $\mathrm{Y}$, Cordon-Cardo $\mathrm{C}_{3}$, Thomson $\mathrm{T}$, et al: Cell surface antigens of human bladder cancer defined by mouse monoclonal antibodies. Proc. Natl. Acad. Sci. U. S. A. 1984; 81 : $224-228$.

35. Mareel MM, Van-Roy FM, De-Baetselier P: The invasive phenotypes. Cancer. Metastasis. Rev. 1990; 9:45-62.

36. Reich $\mathbb{R}$, Thompson $\mathrm{EW}$, Lwamoto $\mathrm{Y}$, ef $a$ : Effects of inhibitors of plasminogen activator, serine proteinases, and collagenase IV on the invasion of basement membranes by metastatic cells. Concer. Res. 1988; 48: $3307-3312$. 
37. Hawenith MG, Arends JW, Simon R, Volovics A, Wiggers T, Bosman FT: Type IV collagen immunoreactivity in colorectal cancer. Prognostic value of basement menbrane deposition. Cancer. 1988; 62: 2207-2211.

38. Hendrix MJ, Wood WR, Seftor $\mathrm{EA}_{\text {, et }}$ al: Retinoic acid inhibition of human mellanoma cell invasion through a reconstituted basement membrane and its relation to decreases in the expression of proteolytic enzymes and motility factor receptor. Cancer. Res. 1990; 50: $4121-4130$.

39. Dano K, Andreasen PA, GrondahL-Hansen J, Kristensen P, Nielsen LS, Skriver L: Plasminogen activators, tissue degradation, and cancer. Adv. Cancer. Res. 1985; 44: 139-266.

40. Bosman FT, Havenith $\mathrm{MG}$, Visser $\mathbb{R}$, Cleutjens JPM: Basentent membranes in neeplasia. Progr. Histochem. Cytochem. 1992; 24: 1.92.

41. Madsen MW, Briand P: Relationship between tumorigenicity, in vitro invasiveness, and plasminogen activator production of human breast cell lines. Eur. J. Cancer. 1990; 26 : $793-797$.

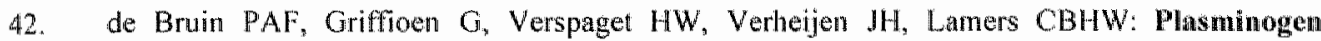
activators and tumor clevelopment in the human colon: activity levels in normal mucosa, adenomatous polyps, and adenocarcinomas. Cancer. Res. 1987; 47: 4654-4657.

43. Pyke C, Kristensen P, Ralfkiaer $E$, ef al: Urokinase-type plasminogen activator is expressed in stromal cells and its receptor in cancer cells at invasive foci in human colon adenocarcinomas. Am. J. Pathol. 1991; 138: 1059-1067.

44. Hollas $W$, Blasi $F$, Boyd $D$ : Role of the urokinase receptor in facilitating extracellular matrix invasion by cultured collon cancer. Cancer. Res. 1991; 51: 3690-3695.

45. Sier CFM, Verspaget $H W$, Griffioen $G$, er al: Imbalance of plasminogen activators and their inhibitors in human colorectal neoplasia. Gastroenterology 1991; 101: 1522-1528.

46. Mareel MM, Behrens J, Birchmeier W, et al: Down-regulation of E-cadherin expression in Madin Darby canine kidney (MDCK) cells inside tumors of nude mice. Int. J. Cancer. 1991; 47: 922-928.

47. Mareel $M$, Vleminckx $K$, Vermeulen $S$, et al: Homotypic cell-cell adliesion molecules and tumor invasion. In. Graumann W, Drukker J, eds. Progress in Histo- and Cytochenistry, 26: Histochemistry of receptors. Stuttgart-Jena-New York: Fischer-Verlag, 1992:95-106.

48. Dorudi $S$, Sheffield JP, Poulsom $R$, Northover JMA, Hart IR: E-cadherin expression in colorectal cancer; An immunohistochemical and in situ hybridization study. Am. J. Pathol. $1993 ; 142: 981-986$.

49. yan der Wurf AA, ten Kate J, van der Linden EPM, Dinjens WNM, Arends J.W, Bosman I"T: L-CAM expression in normal, premalignant, and malignant colon mucosa. J. Pahol. 1992: 168: $287-291$.

50. Springer TA: Adhesion receptors of the immume system. Nature. 1990; 346:425-434.

51. Schreiner C, Baver J, Margolis M, Juliano RL: Expression and role of integrins in adhesion of human colonic carcinoma cells to extracellular matrix components. Clin. Exp. Metastasis. 1991; 9: 163-178.

52. Chan BMC, Matsunra $\mathrm{N}$, Takada $\mathrm{Y}$, Zetter $B R$, Hemler $M E$ : In witro and in wivo consequences of VLA-2 expression on rhabdomyosarcoma cells. Science. 1991; 251 : $1600-1602$. 


\section{CHAPTER 3}

\section{CHROMOSOMAL LOCALIZATION OF}

TRANSFECTED GENES

BY A COMBINATION OF HOT BANDING AND FLUORESCENCE IN SITU HYBRIDIZATION

J.E. de Vries, F.H.A.C. Kornips, J. Wiegant, P.M. Moerkerk, N. Senden, B. Schutte, J.P.M. Geraedts, F. T. Bosman, and J. ten Kate.

J. Histochem. Cyochem. 1992; 40:1053-1058.

(Copyright 1992 by The Histochemical Society) 


\subsection{INTRODUCTION}

A variety of techniques can be applied to introduce foreign DNA into mammalian cells. One of the most widely used transfection techniques consists of the coprecipitation of DNA with calcium phosphate $(1,2)$. It is assumed that, with this technique, integration of introduced DNA into chromosomes occurs at a random site $(3,4,5)$. In contrast, Mckennat al. (6) found in rat embryo fibroblasts, which were morphologically transformed after transfection with the $\mathrm{c}-\mathrm{Ha}$-ras gene that integration frequently occurred in chromosome 3 . These authors postulated as an explanation the existence of a specific receptive integration site on this chromosome. This finding raises the question, whether cellular alterations observed after gene transfection are determined only by the characteristics of the introduced gene or could also be modulated according to the site of integration.

To answer the question whether or not the integration site influences the expression of the transfected gene, and as such might modulate the ensuing alterations in cellular behaviour, it is necessary to visualize and localize the site of integration. By fluorescence in situ laybridization techniques $(7,8,9)$, it is possible to visualize integrated DNA with more speed and with higher spatial resolution than with radioactive in situ hybridization techniques (10). In this study probes labeled by nick translation were compared with random primed labeled probes to develop an optimal procedure for fluorescence in situ hybridization.

To identify the integration sites on specific chromosomes it is necessary to generate a chromosome banding pattern combined with in situ hybridization. However, chromosomes treated with the routine banding techniques are not suited for in situ hybridization (11). One banding technique compatible with in situ hybridization, requires the incorporation of BrdU in the late S-phase of synchronized cells leading to R-banding after Giemsa staining (12-14). However, the synchronization of cells is a time consuming and laborious process. Furthermore a banding method is described when a low trypsin concentration is used in order to obtain banding, with improvement of the cytogenetic analysis by subsequent fluorescence in situ hybridization with chromosome specific centromere probes (15). We chose to use a simple and rapid technique, the so called hot banding (16), as an alternative procedure. It is based on the principle first described by Sumner et al. (16), they induced a banding pattern by incubating chromosome spreads in a hot saline-citrate solution. As test substrate was used the cell line SW480, derived from a human colon carcinoma (17), which was transfected in our laboratory with $\mathrm{pSV}_{2}$ neoEJ, containing the pointmutated c-Ha-ras oncogene (18) within the Bam HI site of the $\mathrm{pSV}_{2}$ neo plasmid.

In this report we describe the combination of hot banding and fluorescence in situ hybridization with nick translated probes to localize the integration site of a plasmid after transfection. 


\subsection{MATERIAL AND METHODS}

\subsubsection{Cell-culture}

SW480 EJ2 was routinely cultured in DMEM supplemented with $5 \%$ fetal calf serum at $37^{\circ} \mathrm{C}$ in a humidified atmosphere with $5 \% \mathrm{CO} 2$. Gentamycine (GIBCO,G418) was added to the culture medium $(800 \mu \mathrm{g} / \mathrm{ml})$. The parent cell line $\mathrm{SW} 480$ is a human colon tumor derived cell line (17).

\subsubsection{Transfection}

The plasmid pSV2neoEJ, containing a $6.6 \mathrm{~kb}$ genomic Bam HI fragment of the $\mathrm{c}$ Ha-ras gene with a $G$ to $T$ transversion in the twelfth codon was a kind gift of Prof. Dr. P. Cerruti. The plasmid pSV2neoEJ was used in transfection experiments with SW480. For transfection the protocol of Graham and van der Eb (1) was followed with modifications as described by Chen and Okayama (2).

\subsubsection{Southern blotting}

Southern blotting was performed following routine procedures (19).

\subsubsection{Chromosome preparation and banding}

Exponentially growing cells were trypsinized and incubated with vinblastin $(0.1 \mu \mathrm{g} / \mathrm{ml})$ for $1 \mathrm{~h}$ at $37^{\circ} \mathrm{C}$. The cells were treated with a hypotonic solution $(1 \%$ sodium citrate; $30^{\prime}$ at $37^{\circ} \mathrm{C}$ ) and fixed three times with methanol:glacial acetic acid $2: 1(\mathrm{v} / \mathrm{v})$. Chromosome spreads were made on clean glass slides and air dried. Metaphase slides were used for hot banding (16) either two weeks after preparation or after overnight heating at $40^{\circ} \mathrm{C}$.

In our hands we found optimal banding at $86^{\circ} \mathrm{C}$ in $2 \times S S C$. At $86^{\circ} \mathrm{C}$ an incubation time of 0.5 minute is minimally required to induce banding. The quality of the banding diminished if incubation times were longer than 4 minutes. The optimal incubation period varied for each batch of chromosome suspension prepared within the incubation periods mentioned. The hot banded metaphase spreads were Giemsa stained. Metaphases were located and photographed. Before in situ hybridization slides were destained in methanol and air dried after dehydration with a graded ethanol series.

\subsubsection{Probe labeling}

The pSV2neo plasmid, $5.6 \mathrm{~kb}$, was labeled with biotin (ENZO) or digoxygenin (Boehringer) by random primed labeling (Boehringer) or nick translation (ENZO) according to manufacturers instruction. Labeled probes were purified by gelfiltration on Sephadex G-50 columns equilibrated with $10 \mathrm{mM}$ Tris.HCl, $1 \mathrm{mM}$ EDTA, pH 7.8. Samples of the labeled probes were serially diluted and spotted on nylon filter (Hybond) for spot blot analysis. 
The remaining probe was ethanol precipitated in the presence of 50 times excess sonicated salmon sperm DNA and dissolved in $50 \%$ deionized formamide, $2 \times S S C, 50$ $\mathrm{mM}$ phosphate, $\mathrm{pH} 7$ at a concentration of $10 \mathrm{ng} / \mathrm{ul}$.

Spot blot analysis of digoxigenin labeled probe was carried out with alkaline phosphatase conjugated sheep-anti-digoxigenin (Fab fragments; Boehringer) followed by NBT/BCIP reaction (Boehringer); spot blot analysis of biotin labeled probes was done with peroxidase conjugated avidin (Sanbio) followed by $D A B$ reaction.

\subsubsection{In situ hybridization}

This was performed according to Wiegant et. al. (9). Briefly, slides were pretreated with RNA'se $A(100 \mu \mathrm{g} / 2 \mathrm{ml} 2 \times \mathrm{SSC})$ for one $\mathrm{hr}$ at $37^{\circ} \mathrm{C}$, followed by treatment with proteinase $\mathrm{K}$. (Merck; $0.1 \mu \mathrm{g}$ Proteinase $\mathrm{K} / 100 \mathrm{ml} 20 \mathrm{mM}$ Tris $\mathrm{HCl}, 2 \mathrm{mM} \mathrm{CaCl} 2, \mathrm{pH}$ 7.4) for $8 \mathrm{~min}$. at $37^{\circ} \mathrm{C}$. Finally, the slides were dehydrated through an ethanol series and air dried.

The hybridization mixture contained per $\mu 50 \%$ deionized formamide, $2 \times S S C, 10 \%$

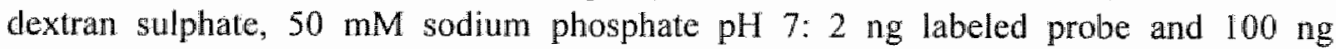
sonicated salmon sperm DNA as carrier DNA. Ten $\mu$ l. of hybridization mixture was put on a slide, covered with an $18 \times 18 \mathrm{~mm}$ coverslip and sealed with rubber cement. Simultaneous denaturation of both probe and target DNA was done by placing the slide on a $80^{\circ} \mathrm{C}$ metal plate for $5 \mathrm{~min}$. After this the slide was transferred to a moist chamber at $37^{\circ} \mathrm{C}$ and the hybridization was proceeded overnight.

\subsubsection{Post hybridization washings and detection}

Slides were immersed in $50 \%$ formamide, $2 \mathrm{xSSC}, 50 \mathrm{mM}$ phosphate $\mathrm{pH} 7$ at $45^{\circ} \mathrm{C}$ for 5 min. to loosen the coverslips. After that the slides were washed $3 \times 5$ min. with $50 \%$ formamide, $2 \times \mathrm{SSC}, 50 \mathrm{mM}$ phosphate $\mathrm{pH} 7$ at $45^{\circ} \mathrm{C}$. Then they were washed for $5 \mathrm{~min}$. with $2 \mathrm{xSSC}, 0.05 \%$ Tween-20 at room temperature.

Prior to the immunocytochemical incubations, the slides were blocked with $4 \times \mathrm{SSC}$, $0.5 \%$ Blocking Reagent (Boehringer) for $10 \mathrm{~min}$. at room temperature. Slides to which biotinated probes were hybridized, were incubated for $30 \mathrm{~min}$. at $37^{\circ} \mathrm{C}$ with $5 \mu \mathrm{g} / \mathrm{ml}$ of Avidin.D-FITC (Vector Laboratories, USA) diluted in 2xSSC, $0.5 \%$ Blocking Reagent. Slides to which digoxigeninated probes were hybridized, were incubated for $30 \mathrm{~min}$. at $37^{\circ} \mathrm{C}$ with sheep-anti-digoxigenin-FITC (Boehringer) diluted in $2 \times \mathrm{SSC}, 0.5 \%$ Blocking Reagent. After 3 washes of 5 min. with $2 \times S S C, 0.05 \%$ Tween- 20 and a $1 \times 5$ min. wash with PBS, the slides were dehydrated through a graded ethanol series and airdried. Finally, the slides were embedded in antifade medium consisting of $2 \%$ 1,4-diazabicyclo-(2,2,2)-octane (DABCO; Sigma, USA) in 9 parts glycerol and 1 part $0.2 \mathrm{M}$ TrisHCl pH 7.5 containing $0.5 \mu \mathrm{g} / \mathrm{ml} \mathrm{4}$, 6-diamidino-2-phenylindole (DAPI) as a general DNA counterstain for photomicrographs and image analysis. Photomicrographs of fluorescence images were taken on a Zeiss Axiophot microscope equipped for epi illumination using Kodak 400 asa black and white film for fotoprints. 


\subsubsection{Image analysis}

Interphase nuclei were analyzed with a BioRad MRC 600 Confocal Scanning Laser Microscope, equipped with a mixed Argon/Krypton gas laser. FITC fluorescence was excited with the $488 \mathrm{~nm}$ laser line and recorded using a $515 \mathrm{lp}$ band pass filter. Settings were adjusted to prevent saturation of the image of the confocal plane with maximum fluorescence intensity. From a projection of a stack of confocal images the average dot intensity per cell was measured and presented in arbitrary units. These were corrected for background levels as follows. A treshold grey level for the mean nuclear background was set arbitrarily, in such a way that in all nuclei the positive dots were visible. Grey levels above this threshold were integrated per cell and recorded as dot intensity.

\subsection{RESULTS}

SW480 cells, transfected with pSV2neoEJ were analysed by southern blotting to detect integration of the plasmid DNA into recipient DNA. Figure 1 shows distinct bands in DNA of transfected cells after hybridization with a $3.8 \mathrm{~kb}$ Pvull fragment of pSV2neo. No bands were observed in control DNA from SW 480 cells. This proves integration of pSV2neoEJ into SW480 after transfection. The cell line, designated SW480 EJ2, was used in further experiments.

Probes, labeled by nick translation and random priming, were analysed in a spot blot test on a nylon filter. The results are illustrated in Figure 2. The lowest detectable amount of probe was similar for both labeling methods: at least $0.5 \mathrm{pg}$ for digoxygeninated DNA and 2 pg for biotinylated DNA without using an amplification step.

Figure 3 illustrates the results of in situ hybridization on interphase nuclei and chromosome spreads. Nick translated probes gave stronger hybridization signals than random primed labeled probes, regardless of the choice of label. By visual estimation probes labeled with digoxigenin gave somewhat better results than probes labeled witl biotin (Fig. 3). The random primed biotin labeled probe did not yield a detectable signal (Fig. 3D). A striking phenomenon was the occurrence of hybridization signals predominantly in the periphery of the interphase nuclei (Fig. 3).

To quantify the two different labeling methods after in situ hybridization, the intensities of the specific signals in interphase nuclei were measured with confocal scanning laser. microscopy. The results are summarized in table 1 . The signal intensity between individual nuclei showed a wide variation (Tables 1 and 2). On the average the nick translated digoxygenin labeled probes yielded a threefold higher signal intensity than random primed digoxigenin labeled probes. This difference was statistically significant (Table 1). Similarly, nick translated biotin labeled probes yielded a higher signal than random primed biotin labeled probes, the latter remaining undetectable above background level. Finally, the digoxigenin signal appeared to be twofold higher than 

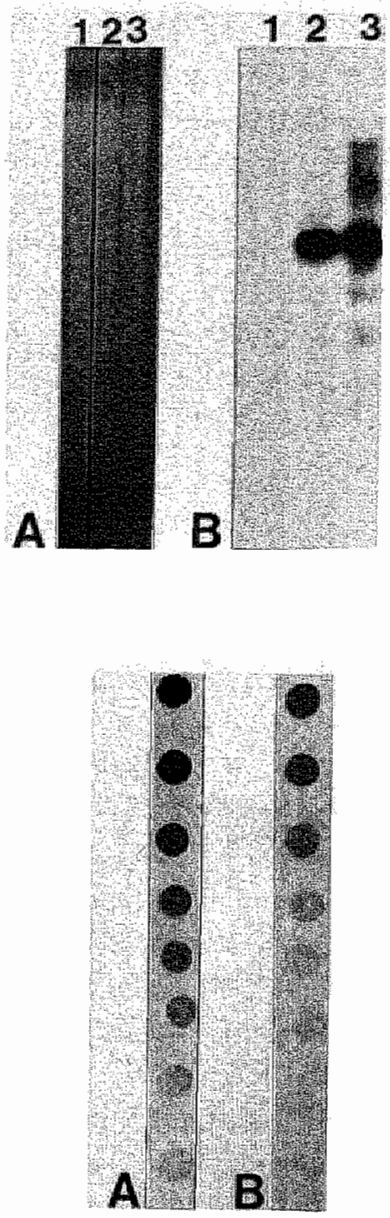

Figure 1. Integration of plasmid DNA in transfected SW480 cell limes.

A. Ethidium bromide stained $0.8 \%$ agarose gel loaded with 10 Mg BamHI digested chromosomal DNA. Lane 1. SW480; 2 : SW480 EJ1:3: SW480 EJ2. B. Southern blot of the gel shown in A. The $3.8 \mathrm{~kb}$ Pwull fragment of $\mathrm{pSV}_{2}$ neo was used as probe.
Figure 2. Visualization of $\mathrm{pSV}_{2}$ neo labeled with digoxigenin by spot-blotting.

A. $\mathrm{pSV}_{2}$ neo labeled by nick translation; B. $\mathrm{pSV}_{2}$ neo labeled by random prining.

Table I. Nick tramslation compared with random primed labeling.

\begin{tabular}{lllll}
\hline Labeling & Mean $^{\mathrm{a}}$ & SEM $^{\text {b }}$ & Range & n \\
\hline Nick translation & $1935^{\circ}$ & 353 & $876-3403$ & 7 \\
Random priming & $659^{\circ}$ & 136 & $319-1312$ & 7 \\
\hline
\end{tabular}

a. Pixel intensity (arbitrary units) measured by confocal scan laser microscopy of $\mathrm{SW} 480 \mathrm{EJ} 2$ interphase nuclei, hybridized with a digoxigenin labeled $\mathrm{pSV}_{2}$ neo probe.

b. Standard error of the nean.

* $p<0.01$, as analysed with Student's $t$-test. 
biotin for nick translation labeled probes, which was statistically significant also (Table 2).
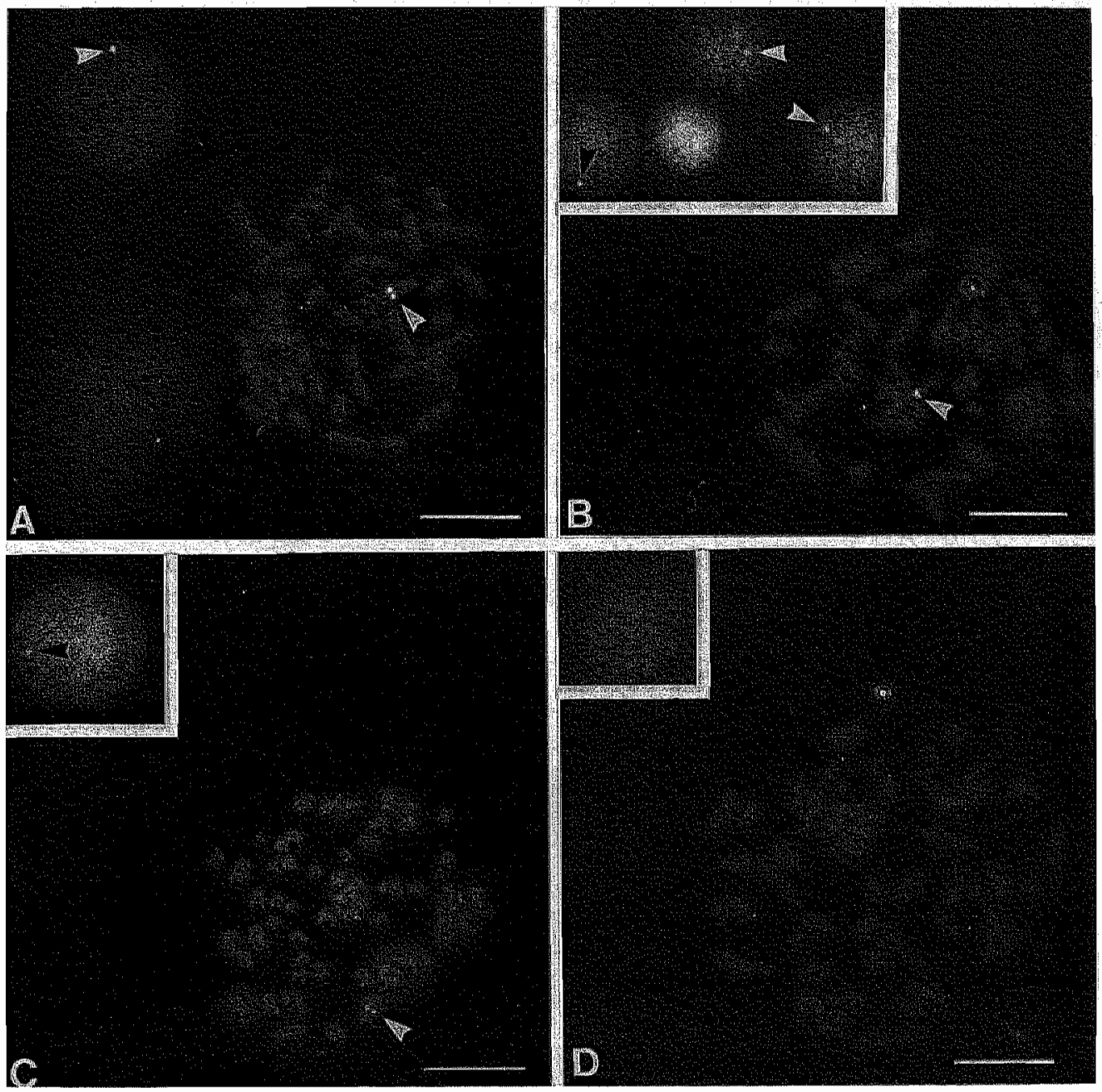

Figure 3. Intensity of fluorescence in situ hybridization signalls.

Microphotographs were obtained by fluorescence microscopy of interphase nuclei and metaphase spreads of SW480 EJ2 after hybridization with: A. Nick translated digoxigenin labeled $\mathrm{pSV}_{2}$ neo; $\mathbf{B}_{\text {. }}$ Nick translated biotin labeled $\mathrm{pSV}_{2}$ neo; $\mathrm{C}$. Random primed digoxigenin labeled $\mathrm{pSV}$, neo; D. Random primed biotin labeled $\mathrm{pSV}_{2}$ neo. The chromosomes and interphase nuclei were counterstained with DAPI. Arrows indicate the hybridization signals. Insets (same magnification) show interphase nuclei with hybridization signals. $\mathrm{Bar}=10 \mu \mathrm{m}$. 
Table 2. Comparison of probes labeled with digoxygenin or biotin.

\begin{tabular}{lcccc}
\hline Label & Mean $^{*}$ & SEM $^{\circ}$ & Range & n \\
\hline Digoxygenin & $2649^{\circ}$ & 246 & $270-7612$ & 45 \\
Biotin & $1236^{\circ}$ & 160 & $123-4500$ & 49 \\
\hline
\end{tabular}

a. Pixel intensity (arbitrary units) measured by confocal scan laser microscopy of $S W 480$ EJ2 interphase nuclei, hybridized with a nick translated $p S V_{2}$ meo probe.

b. Standard error of the mean.

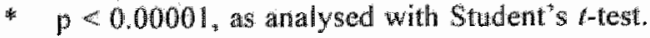

To localize the integration site of the plasmid in the SW480 EJ2 cell line, metaphase spreads were hot bandled, followed by fluorescence in situ hybridization. After hot banding, $100 \%$ of the metaphase spreads and interphase nuclei showed positivity in the fluorescence in situ hybridization, albeit that the intensity of the signals varied widely and was less intense compared with not hot banded preparates by visual observation. Figure 4A shows a hot banded metafase spread and figure $4 \mathrm{~B}$ shows the same metaphase spread after fluorescence in situ hybridization. The hybridization signal is seen as two bright spots. The chromosome was karyotyped as the X-chromosome, with a translocation possibly involving the $5 q$ arm. The integration of pSV2neoEJ is localized at the translocation site. This marker chromosome was not found in the parent SW480 cell line.
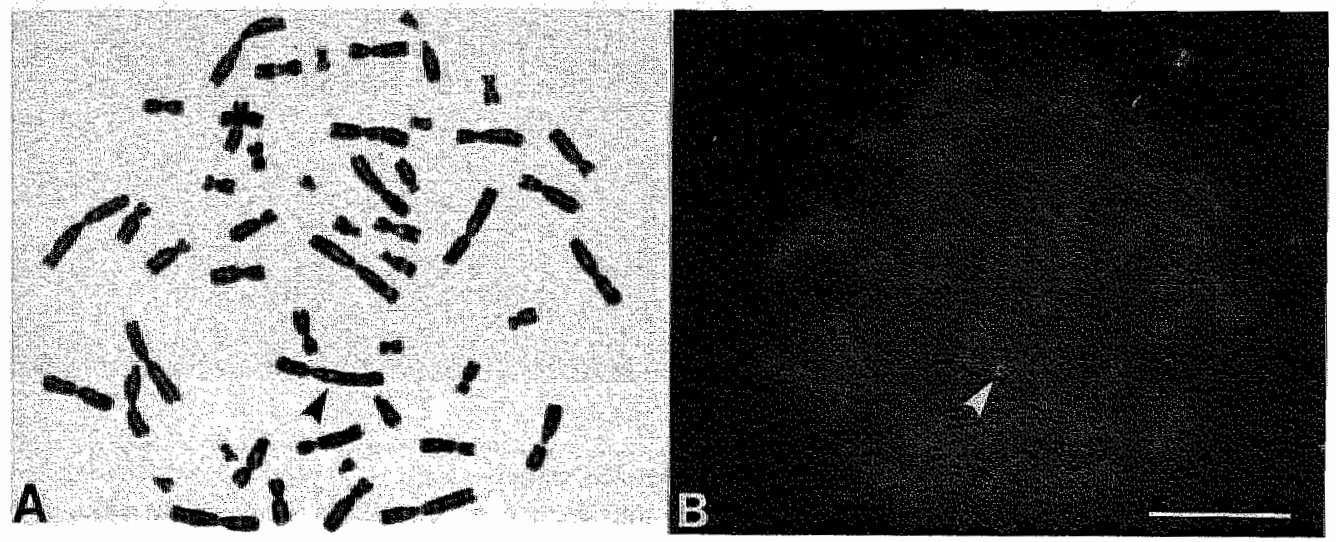

Figure 4, Detection of a chromosomal integration site in SW 480 E.2 by hot banding and FISH. A. Metaphase spread after hot banding; B. The hot banded metaphase spread of A after fluorescence in situ hybridization. Arrow indicates the hybridization signal on marker chromosome $X_{\mathrm{p}^{+}}$. Bar $=10 \mu \mathrm{m}$. 


\subsection{DISCUSSION}

With a variety of transfection techniques it is possible to achieve stable integration of DNA sequences into an eukaryotic genome $(1,2)$. The site of integration in the recipient genome can be relatively easily located by fluorescence in situ bybridization (7-9). Stable labels, like AAF (20), BrdU (21) and recently digoxigenin (Boehringer), can be used as haptens, which can be visualized with antibodies conjugated with fuorochromes or the biotin-avidin system can be exploited (22). Probes can be labeled by nick translation or by random priming labeling methods.

In theory, random primed labeling should be superior, since a more efficient incorporation of labeled nucleotides into the probe is obtained as compared to nick

translation. To determine optimal conditions for our experiments we compared both methods and found that nick translated probes gave better signals than random primed labeled probes, regardless of the label used (Figure 3, table 1). Nick translated probes yielded detection levels similar to those of random primed labeled probes as analysed by spot blots (Figure 2).

The cause of the difference in sensitivity in fluorescence in situ hybridization is not clear. The difference in signal intensities may be due to the labeling procedures which were carried out as described in the manufacturers protocols. In our hands nick translation was optimal, although we do not exclude that the procedure of random primed labeling could be optimized, so that the signal to background ratio may increase and match the nick translation results.

We measured, by confocal scanning laser microscopy, that the hybridization signal of digoxygenin labeled probes is on the average twice as high than that of biotin labeled probes (Tables 1 and 2) and that for our purposes the method of choice is a nick translated digoxigenin labeled probe, although in principle both labeling methods are applicable.

With fluorescence in situ hybridization the integration site in interphase nuclei was visualized. A recent study suggested that integration of plasmid. DNA, introduced by calcium phosphate precipitation, might occur through non-homologous recombination (23), thus favoring random integration. The integration sites of our plasmid, however, appeared not to be randomly distributed, but in most of the interphase nuclei were located at the periphery of the nucleus. Several explanations should be considered for this observation. Firstly, plasmid DNA might integrate randomly into genomic DNA as soon as it is encountered at the periphery of the nucleus. Secondly, plasmid DNA might integrate randomly into genomic DNA throughout the nucleus. Once integrated it has to be actively transcribed for the transfectant to survive in selective medium. Actively transcribed genes are mostly located in the nuclear periphery (24). Finally, active DNA sequences might be more accessible to integration than inactive DNA sequences, which are highly condensed and shielded with histon proteins $(25,26)$. This would imply that transcriptionally active genes would be the most frequent target for integration of a transfected gene. The observation of Gruenert (27), who noted highest transfection 
efficiency in exponentially growing cells which have a very high transcriptional activity, supports this notion. Indirect support for the involvement of active DNA sequences in integration, comes from viral integration studies where integration is associated with DNA'se I hypersensitive sites, a characteristic of genes actively transcribed (28).

We conclude that random integration in transcriptionally active DNA can explain the location of the integrated plasmid at the periphery of the interphase nuclei.

To study the relationship between the site of integration and the expression of the transfected gene, and secondly between the site of integration and the subsequent changes in cellular behaviour, the fluorescence in situ hybridization was combined with hot banding. To our knowledge this combination has not been described before. The site of the integration, specific or random, can then be assessed on a chromosomal level. Because hot banding is a simple and rapid technique, it can be employed to analyse large numbers of transfectants.

The integration site of plasmid pSV2neoEJ in the cell line SW480 EJ2 was localized on a marker chromosome, $\mathrm{Xpt}$, at the site of the translocation (Figure 4). Analysis of more transfectants will give us the knowledge whether integration is specific or random on a chromosomal level. With hot banding and fluorescence in situ hybridization this can be done fast and efficient.

In conclusion: 1. Nick translated, digoxygenin labeled probes yield in our fluorescence in situ hybridization procedure the most optimal results. 2. The integration site is localized in most interphase nuclei at the periphery, which could be explained by random integration in transcriptionally active DNA. 3. The combination of hot banding and fluorescence in situ hybridization can be used to localize plasmid integration sites on chromosomes. 


\subsection{REFERENCES}

1. Graham FL, van der Eb AJ: A new technique for the assay of infectivity of human adenovirus 5 DNA. Virology 1973; $52 ; 456-467$.

2. Chen $\mathrm{C}$, Okayama $\mathrm{H}$ : High-efficiency transformation of mammalian cells by plasmid DNA. Mol. Cell. Biol. 1987; 7: 2745-2752.

3. Pellicer A, Robins D, Wold B, et al: Altering genotype and phenotype by DNA-mediated gene transfer. Science. 1980; 209: 1414-1422.

4. Hsiung $\mathbb{N}$, Warrick $\mathrm{H}$, DeRiel $\mathrm{JK}$, ef al: Cotransfer of circular and linear prokaryotic and eukaryotic DNA sequences into mouse cells. Proc. Natl. Acad. Sci. USA 1980; 77: $4852-4856$.

5. Robins DM, Ripley S, Henderson AS, Axel R: Transforming DNA integrates into the host genome. Cell. 1981; 23: 29-39.

6. McKenna WG, Nakahara $K$, Muschel RJ: Site-specific integration of H-ras in transformed rat embryo cells. Science. 1988; 241: 1325-1328.

7. Boyd $\mathbb{E}$, Theriault A, Goddard JP, Kalaitsidaki M, Spathas DH, Connor JM: Chromosomal assignment of a glutamic acid transfer RNA (tRNAGlu) gene to 1p36. Hum. Genet. 1989; 81: $153-156$.

8. Vernole P: Digoxigenin-labeled probes can detect single-copy genes in human nuetaphase chromosomes. Brotechniques. 1990; 9: 200-204.

9. Wiegant $J$, Galjart NJ, Raap AK, d'Azzo A: The gene encoding human protective protein (PPGB) is on chromosome 20. Genomics. 1991; 10:345-349.

10. Pallavicini $\mathrm{MG}$, DeTeresa PS, Wurm FM: Use of fluorescence in situ hybridization to detect and monitor transfected and amplified sequences in recombinant $\mathrm{CHO}$ cells. Dev. Bioll. Stand. $1989 ; 70: 165-1.72$.

11. Malcolm S, Cowell JK, Young BD: Specialist techniques in research and diagnostic clinical cytogenetics. In: Rooney DE, Czepulkovski BH, eds. Human Genetics: A practical approach. Oxford, Washington: IRL Press, 1986:197-.

12. Viegas-Pequignot E, Li ZL, Dutrillaux B, Apiou F, Paulin D: Assignment of human dlesmin gene to band $2 q 35$ by nonradioactive in situ hybridization. Hum. Genet. 1989; 83: 33-36.

13. Cherif D, Julier C, Delattre O, Derre J, Lathrop GM, Berger R: Simultaneous Iocalization of cosmids and chromosome $R$-banding by florescence micrescopy: application to regional mapping of human chromosome 11. Proc. Natl. Acad. Sci. U. S. A. 1990; 87: 6639-6643.

14. Ronne $M$, Kirpekar $F$, Shibasaki $Y$, Poulsen BS, Kristiansen $K$ : $R$-banding and in situ hybridization locallization of single copy genes on high resolution banded chromosomes. Anticancer. Res. 1990;10:375-377.

15. Smit VT, Wessels IW, Mollewanger $\mathrm{P}$, et al: Combined GTG-banding and noniradioactive in situ hybridization improves characterization of complex karyotypes. Cytogenet. Cell. Genet. 1990; 54: 20-23.

16. Sumner AT, Evans HJ, Buckland RA: New technique for distinguishing between human chromosomes. Nature. 1971; 232: 31-32.

17. Leibovitz A, Stinson JC, McCombs WB, et al: Classification of human colorectal adenocarcinoma cell lines. Cancer Research 1976; 36: 4562-4569.

18. Capon DJ, Chen EY, Levinson AD, Seeburg $P H_{\text {s }}$ Goeddel DV: Complete nucleotide sequences of the T24 human bladder carcinoma oncogene and its normal homologue. Nature. 1983:302:33-37.

19. Sambrook J. Fritsch EF, Maniatis T: Molecular eloning. second ed. New York: Cold Spring Harbor Laboratory Press, 1989 
20. Landegent JE, Jasen-in-de-Wal $N$, Baan RA, Hoeijmakers JH, Van-der-Ploeg $M$ : 2-Axetylaninofluorenemodified probes for the indireet hybridocytochemical detection of specific nucleic acid sequences. Exp. Ceill. Res. 1984; 153:61-72.

21. Frommer M, Paul $C$, Vincent PC: Localisation of satellite DNA sequences on human metaphase chromosomes osing bromodeoxyuridine-labelled probes. Chromosoma. 1988; 97 : $11-18$.

22. Pinkel $\mathrm{D}$, Straume $T$, Gray $\mathrm{JW}$ : Cytogenetic analysis using quantitative, high-sensitivity, nuorescence hybridization. Proc. Nati. Acad. Sci. U. S. A. 1986; 83: 2934-2938.

23. Murnane JP, Yezzi MJ, Young BR. Recombination events during integration of transfected DNA into normal human cells. Wucleic. Acids. Res. 1990; 18: 2733-2738.

24. Krystosek $A, P u c k$ TH: The spatial distribution of exposed nuclear DNA in normal, cancer, and reverse transformed cells. Proe. Natl. Acad. Sci. U. S. A. 1990;87: 6560-6564.

25. Kaplan $\mathrm{JG}_{\mathrm{G}}$ Brown $\mathrm{DL}$, Chaly $\mathrm{N}$, el al: Structural and evolutionary implications of the packaging of DNA for differentiation and proliferation in the lymphocyte. I. Mol. Evol. $1987 ; 26: 173-179$.

26. Weintraub $H$ : Assembly and propagation of repressed and depressed chromosomal states.. Cell 1985; $42: 705-711$.

27. Gruenert DC: Differentiated properties of human epithelial cells transformed in vitro. Biotechniques. 1987; 5: 740-749.

28. Schubach $W$, Groudine $M$ : Alteration of c-myc chromatin structure by avian leukosis virus integration. Nature. 1984: 307: 702-708. 


\section{CHAPTER 4}

\section{TRANSFECTED C-HA-RAS ONCOGENE ENHANCES KARYOTYPIC INSTABILITY AND INTEGRATES PREDOMINANTLY IN ABERRANT CHROMOSOMES}

J.E. de Vries, F.H.A.C. Kornips, P. Marx, J.P.M. Geraedts, F.T". Bosman, and J. ten Kate.

Cancer Genet. Cytogener. 1993; 65: 35-43.

(Copyright 1993 by Elsewier Science Publishing Company, Inc) 


\subsection{INTRODUCTION}

In studies with genes involved in initiation and progression of cancer, gene transfection has been used to investigate the role of particular (normal or abnormal) genes in disturbed cell function. Thus, transfection of the c-Ha-ras oncogene was shown to convey metastatic potential to NIH $3 \mathrm{~T} 3$ cells. This change in cell behavior might be caused by expression of the c-Ha-ras oncogene or by overexpression of the wild type cHa-ras gene (1-3). Both have been shown to induce upregulation in the activity of collagenase, gelatinase, and urokinase plasminogen activator (4-9), suggesting a role for the c-Ha-ras oncogene in induction of tumor cell invasion. In addition, increased expression of the epidermal growth factor receptor (EGFR) has been demonstrated (10), which may sensitize cells to a mitogenic stimulus of $\mathbb{E G F}$. The observed effects of the c-Ha-ras oncogene may depend on the genotypic and phenotypic characteristics of the recipient cell $(11,12)$.

The progression of cancer in vivo is associated with increase of chromosome aberrations and aneuploidy (13). Some oncogene transfection studies have included cytogenetic analysis before and after transfection $(12,14-16)$. These studies report interesting though conflicting data. Rat mammary and rat prostatic cancer cells showed a significant increase in structural and numerical chromosome changes after c-Ha-ras oncogene transfection $(14,15)$. Induction of metastatic potential in rat mammary cancer cells was associated with gain of chromosome 4 (14). A human urothelial cell line transfected with the $\mathrm{c}$-Ha-ras oncogene showed loss of chromosome arms $3 \mathrm{p}, 10 \mathrm{p}, 1 \mathrm{lp}$ and 18, all of which might contain tumor suppressor genes (12). In contrast, MSU 1.1, a human fibroblast cell line, which displayed invasive capacity after c-Ha-ras oncogene transfection, showed no change in karyotype (16). The limited number of human cell lines analyzed cytogenetically after c-Ha-ras oncogene transfection and the lack of studies reporting transfection with the wild-type c-Ha-ras gene, make it difficult to ascribe induction of cytogenetic changes to specific expression of the c-Ha-ras oncogene.

Although the genotypic and phenotypic background of the recipient cell may contribute to the effects of the introduced c-Ha-ras oncogene, the site of integration might also be important. Viral integration can activate oncogenes by insertional mutagenesis, thus contributing to virus induced carcinogenesis (17). Recently, this was illustrated for hepatocellular carcinoma by integration of the hepatitis B wirus in a cyclin A gene (18), a gene important in control of cell division (19). Integration of the c-Ha-ras oncogene at a specific chromosome site in rat embryo fibroblasts has suggested that the effect of transfection with the c-Ha-ras oncogene might depend on the site of integration (20), indicating that important information can be obtained by identifying integration sites of exogenous DNA.

To gain more insight into the way in which cellular changes are caused by the c-Harras oncogene, we transfected SW480, a human colon carcinoma cell line (21), with the c- 
Ha-ras oncogene and performed a detailed cytogenetic analysis in combination with localization of the chromosome integration sites.

\subsection{MATERIAL AND METHODS}

\subsubsection{Cell culture and transfection}

The SW480 cells (21) were cultured in Dulbecco's modified Eagle's medium (DMEM), with $5 \%$ fetal calf serum (Boehringer, Mannheim, Germany) at $37^{\circ} \mathrm{C}$ in a humidilied atmosphere containing $5 \% \mathrm{CO}_{2}$.

The plasmid $\mathrm{pSV}_{2}$ neo $(22)$ contains the neomycin gene, which provides resistance against the antibiotic gentamycin. The plasmid $\mathrm{pSV}_{2}$ neoEJ contains a 6.6 kilobase $(\mathrm{kb})$ genomic BamHI fragment of the c-Ha-Ras oncogene with a $G$ to $T$ transversion in codon 12 (23). The plasmid $\mathrm{pSV}_{2}$ neoCO contains the 6.6-kb genomic BamHI fragment of the wild type c-Ha-Ras gene (24). $\mathrm{pSV}_{2}$ neoEJ and $\mathrm{pSV}_{2}$ neocO were gifts from $\mathrm{Dr}$, P.A. Cerutti (Swiss Institute for Experimental Cancer Research, $\mathrm{CH}-1066$ Epalinges, Switzerland). The alkaline lysis method (25) was used for isolation of the plasmids, further purified by precipitation with $\mathrm{NH}_{4} \mathrm{Ac}(7.5 \mathrm{M})$.

For transfection the protocol of Graham and van der Eb (26) was used with the modifications described by Chen and Okayama (27). The plasmid/ $\mathrm{CaCl}_{2}$ mixture was added to N,N-bis(2-hydroxyethyl)-2-aminoethane-sulfonic acid (BES)-buffered saline in continuous airflow (N. Stam, personal communication, NKI, Amsterdam, The Netherlands).

Cell lines were established using two procedures. Two days after transfection, SW480 cells were plated in 96 well plates, where selection was started by addition of G418 ( $800 \mu \mathrm{g} / \mathrm{ml}$, GIBCO, Gaithersburg, USA) to the culture medium. After 3 weeks, selection was completed and colonies began to grow in 96 well plates. Only wells containing one colony were used for further experiments, yielding the cell lines SW480 EJ1, 2, and 4. Alternatively, 2 days after transfection $\mathrm{SW} 480$ cells were transferred into $75-\mathrm{cm}^{2}$ culture flasks and selection was started $(\mathrm{G} 41.8,800 \mu \mathrm{g} / \mathrm{ml})$. Untransfected cells were no longer viable after 3 weeks, and colonies of transfected cells began to grow. These were trypsinized and plated in 96 well plates by limiting dilution. Only wells with one colony were used for further experiments, yielding the cell lines SW480 EJ6, $\mathrm{CO} 5$, and $\mathrm{NEO} 12$.

\subsubsection{Northern blotting}

Cytoplasmic mRNA was isolated after lysis of cells with NP40 in the presence of vanadyl ribonucleoside complex. Cell nuclei were pelleted and discarded. The supernatant was extracted with phenol/chloroform mixture and precipitated with ethanol (25). After gel electrophoresis and blotting on nylon filter, mRNA was hybridized with a $3.0-\mathrm{kb}$ Sacl fragment of the wild-type c-Ha-ras gene, random-primed-labeled with $\left({ }^{32} \mathrm{P}\right) \mathrm{dCTP}$. The amount of mRNA loaded was demonstrated by hybridization with a 
probe specific for actin. The hybridization signals were scanned with a densitometer (LKB Ultrascan XL, Uppsalai). The relative expression of exogenous c-Ha-ras mRNA was determined by normalizing the units obtained for endogenous c-Ha-ras mRNA expression in SW480. The hybridization signals of actin were used to correct for differences caused by unequal loading of mRNA.

\subsubsection{Karyotyping}

Exponentially growing cells were trypsinized and incubated with vinblastine $(0.1 \mu \mathrm{g} /$ $\mathrm{ml}, 45$ minutes, $\left.37^{\circ} \mathrm{C}\right)$. The cells were treated with a hypotonic solution ( $1 \%$ sodium citrate, 45 minutes, $37^{\circ} \mathrm{C}$ ) and fixed in three changes of methanol:glacial acetic acid 2:1 (vol/vol). Chromosome spreads were made on clean glass slides and air dried.

Routine trypsin treatment was performed on metaphase chromosomes used for karyotyping, according to the International System for Human Cytogenetic Nomenclature (ISCN, 1991) (28). Loss of a specific chromosome in one cell was considered a technical artifact. Karyotypic instability of a cell line was determined by adding the number of clonal chromosome abnormalities not observed in all cells to the number of non clonal chromosome abnormalities; this number was divided by the number of cells analyzed.

Either a short trypsin treatment (29) or hot banding (30) was performed on metaphase chromosomes before performance of fluorescence in situ hybridization (FISH). The metaphases were located, photographed, and immediately rinsed in xylol, air dried and destained in methanol and air dried (31).

\subsubsection{FISH}

FISH was performed according to the method of Wiegant et al. (32) with a digoxigenin dUTP-labeled (Boehringer Mannheim) $\mathrm{pSV}_{2}$ neo as probe. Digoxigenin was incorporated by nick-translation (Promega kit). After overnight hybridization and washing (32), slides were blocked in $2 \times \mathrm{SSC}, 0.5 \%$ blocking reagent (Boehringer) (10 minutes, RT) and incubated with sheep-antidigoxigenin-FITC (Boehringer) $\left(30\right.$ minutes, $\left.37^{\circ} \mathrm{C}\right)$, diluted in $2 \times \mathrm{SSC}, 0.05 \%$ Tween-20. The slides were washed with $2 \times$ SSC, $0.05 \%$ Tween-20 three times for 5 minutes each time (RT), dehydrated through a graded ethanol series, air dried, and embedded in 2\% 1,4-diazt-bicyclo-(2,2,2)-octane (DABCO, Sigma, St. Louis, MO) in glycerol/0.2 M Tris. $\mathrm{HCl} \mathrm{pH} 7.5(9: 1 ; \mathrm{vol} / \mathrm{vol})$ containing $0.5 \mu \mathrm{g} / \mathrm{ml} 4-$, 6-dianidino-2-phenylindole (DAPI) to counterstain DNA for photomicrography.

FITC fluorescence was excited with the $488 \mathrm{~nm}$ laser line and recorded using a $515 \mathrm{lp}$ bandpass filter. Photomicrographs were taken on a Zeiss Axiophot microscope equipped for epi-illumination, using Kodak 400 ASA black and white film for photoprints. 


\subsection{RESULTS}

\section{Expression of c-Ha-ras mRNA}

Transfection yielded 23 stable clones with the c-Ha-ras oncogene and five stable clones with the wild-type c-Ha-ras gene, but of these 28 cell lines only three showed enhanced expression of c-Ha-ras mRNA (Table 1). Two cell lines (SW480 EI1 and SW480 EJ2) showed a moderate increase in expression in c-Ha-ras mRNA after transfection with the c-Ha-ras oncogene. One cell line, SW480 CO5, demonstrated a significant increase in $\mathrm{C}-$ Ha-ras mRNA expression after transfection with the wild-type c-Ha-ras gene. of 11 control cell lines isolated after transfection with $\mathrm{pSV}_{2}$ neo, none displayed increased levels of c-Ha-ras mRNA.

Table 1. Expression of c-Ha-ras mRNA, modal chromosome number, ploidy level and karyotypic instability of $\mathrm{SW} 480$ and transfected cell lines.

\begin{tabular}{lcccc}
\hline Cell line & $\begin{array}{l}\text { c-Ha-Ras } \\
\text { mRNA }\end{array}$ & $\begin{array}{l}\text { Modial chromosome } \\
\text { No. (Range) } \\
(\mathrm{n}=10)\end{array}$ & $\begin{array}{l}\text { Diploid: } \\
\text { tetraploid } \\
(\mathrm{n}=100)\end{array}$ & $\begin{array}{l}\text { Karyotypic } \\
\text { instability } \\
\pm \mathrm{S}_{\text {D:S }}(\mathrm{n})\end{array}$ \\
\hline SW480 & 1 & $54(50-106)$ & $68: 32$ & $1.4 \pm 1.5(10)$ \\
SW480 EJ1 & 5 & $100(49-104)$ & $32: 68$ & $3.9 \pm 1.8(11)$ \\
SW480 EJ2 & 4 & $53(50-105)$ & $70: 30$ & $2.4 \pm 1.9(14)$ \\
SW480 EJ4 & 1 & $53(48-107)$ & $70: 30$ & $1.5 \pm 0.5(10)$ \\
SW480 EJ6 & 1 & $53(51-98)$ & $65: 35$ & $0.4 \pm 0.5(7)$ \\
SW480 CO5 & 30 & $49(48-95)$ & $71: 29$ & $1.3 \pm 1.7(9)$ \\
SW480 NEO12 & 1 & $52(50-104)$ & $64: 36$ & $0.9 \pm 1.2(10)$ \\
\hline
\end{tabular}

* Difference with SW480 and SW480 NEO12 is statistically significant $(\mathrm{P}<0.005)$ as analyzed with the Student's t-test.

The three cell lines with increased expression of c-Ha-ras mRNA were further investigated. To determine the effects of the transfection procedure, two c-Ha-ras oncogene-transfected cell lines without increased levels of c-Ha-ras mRNA and one $\mathrm{pSV}_{2}$ neo-transfected cell line also were analyzed.

\section{Modal chromosome number}

The modal chromosome number of $S W 480$ cells was 54 , with a wide range (50-106). For all transfected cell lines, the range in chromosome number was similar to that observed in SW480, but in SW480 EJl it was increased, in parallel with a higher percentage of hypertetraploid cells (Table 1). 

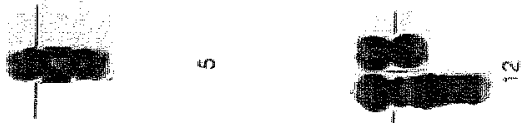

$1+\frac{1}{1} \pm \mathrm{x}$
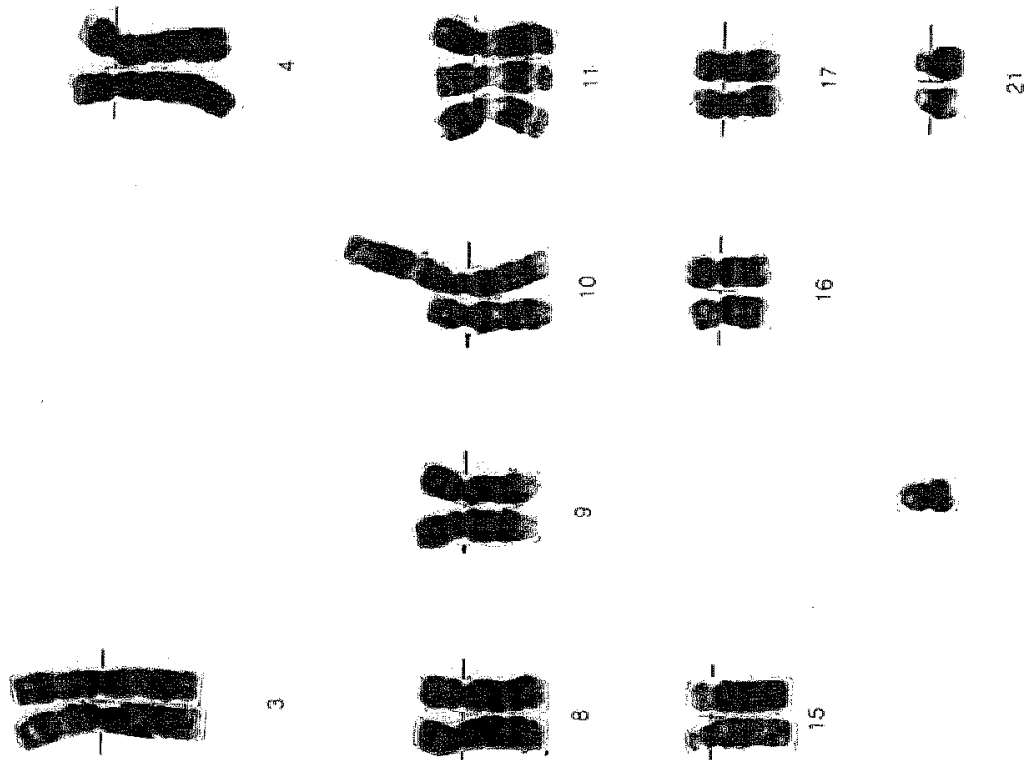

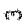
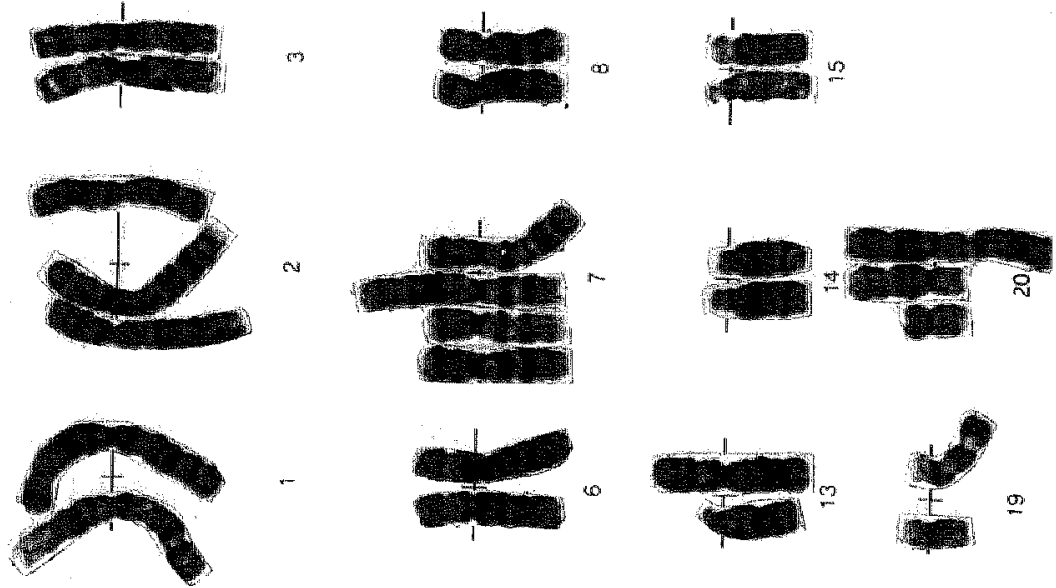


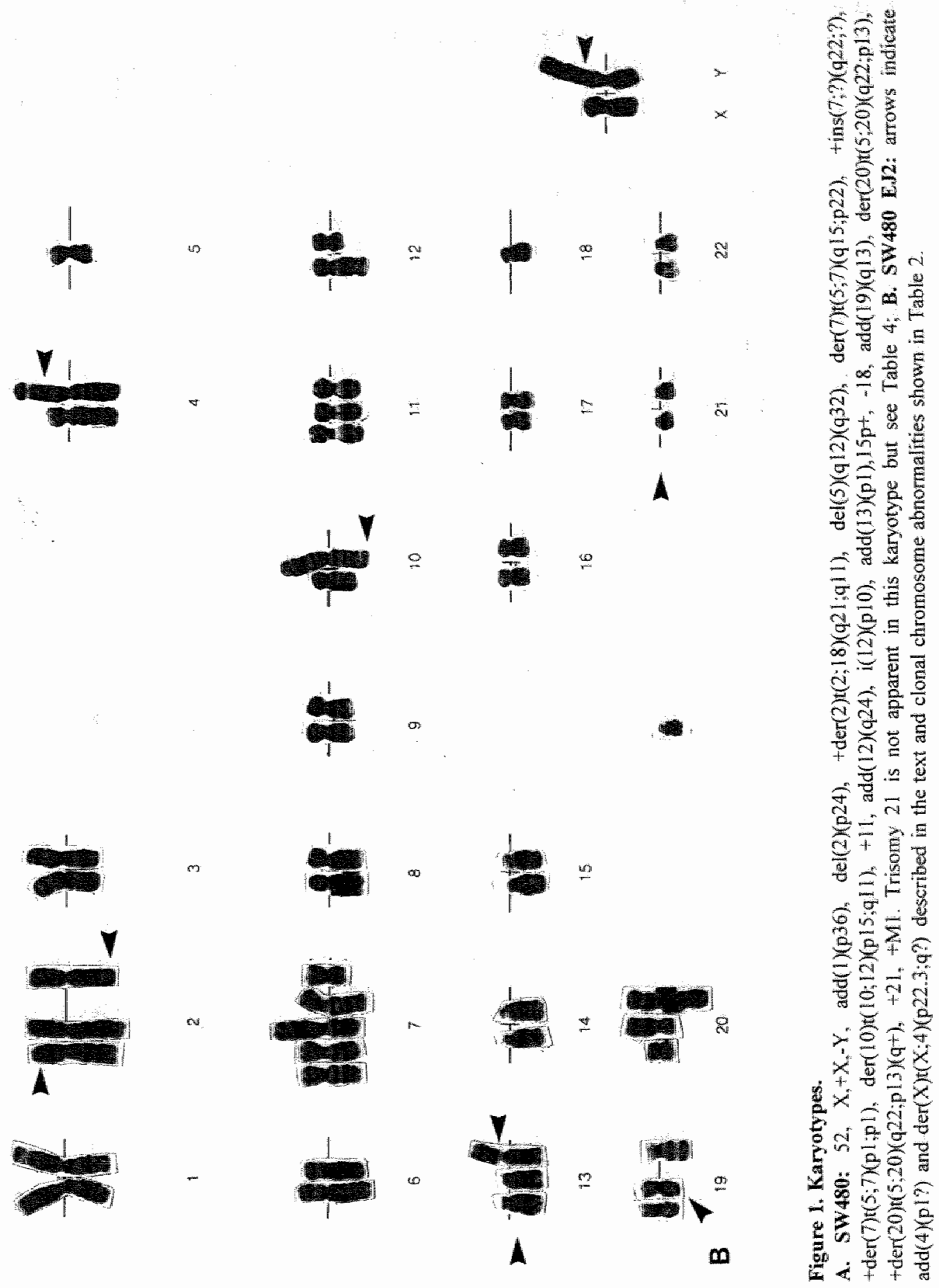




\section{Clonal chromosone changes}

A representative karyogram of $\mathrm{SW} 480$ demonstrating most of the clonal chromosome abnormalities is shown in Figure 1. In addition to the rearranged chromosomes observed earlier $(33,34)$, new structurally rearranged chromosomes, including $i(12)(\mathrm{p} 10)$ and add $(12)(q 24)$, were observed in all cells.

All transfected cell lines showed additional clonal abnormalities present in every cell, comprising numerical and structural chromosome alterations (Table 2). The number of clonal changes per cell line varied from eight in SW480 EJ4 to three in SW480 NEO12. SW480 EJ1 showed loss of two normal and two structurally rearranged chromosomes, but also a new marker chromosome. In SW480 EJ2 three new structurally rearranged chromosomes were observed (Fig. 1). Two of these new chromosomes probably were derived from the der(2) and der(10) present in SW480. Furthermore, trisomy 21 , present in SW480, was not observed in SW480 EJ2, and the abnormal chromosome add(13)(pl) was lost, although this loss was compensated by gain of a chromosome 13 with cytogenetically normal appearance. The other two SW480 cell lines, SW480 EJ4 and SW480 EJ6, transfected with the c-Ha-ras oncogene but without increased c-Ha-ras mRNA levels, also showed additional clonal abnormalities in all cells. A der(19)t(1;19) was observed in most cells in SW480 EJ6 but this structurally rearranged chromosome was present in SW480 with a lower frequency ( 1 of 10 ).

Table 2. Clonal abnormalities in transfected cell lines, present in all cells, compared to $\mathrm{SW} 480$.

\begin{tabular}{|c|c|c|c|}
\hline Cell line & $\begin{array}{l}\text { No. of } \\
\text { metaphases }\end{array}$ & $\begin{array}{l}\text { Numerical changes in } \\
\text { existing chromosomes }\end{array}$ & $\begin{array}{l}\text { New structural } \\
\text { rearrangements }\end{array}$ \\
\hline SW480 EJI & 11 & $-3,-13 p+,-19 q+,-20$ & $+\mathrm{Ml}$ \\
\hline SW480 EJI2 & 14 & $\begin{array}{l}-2 p-,-13 p+,-21 \\
+13\end{array}$ & $\begin{array}{l}\operatorname{der}(2) \mathrm{t}(2 ; 18 ; ?)(\mathrm{q} 21 ; \mathrm{q} 11 ; 7) \\
\operatorname{der}(10) \mathrm{t}(10 ; 12 ; ?)(\mathrm{p} 15 ; \mathrm{q} 11 ; ?) \\
+\operatorname{der}(13) \mathrm{t}(13 \mathrm{p} ; 14 \mathrm{q}),+19 \mathrm{q}^{*}\end{array}$ \\
\hline SW480 EJ/4 & 10 & $\begin{array}{l}-13 p+-18 \\
+22\end{array}$ & $\begin{array}{l}+(\text { der } 7),(1 ; 7)(q 2 ; q 22),+15 p+ \\
17 q+,+20 p+,+ \text { mar } 1\end{array}$ \\
\hline $\mathrm{SW} 480 \mathrm{EJ} 6$ & 8 & $+10,-12 q+,-21$ & $+12 q-15 p+$ \\
\hline SW480 CO5 & 9 & $\begin{array}{l}-13 p+,-20,-21,-x \\
+ \text { der }(20) t(5 ; 20)(q 22 ; p 13)\end{array}$ & $\begin{array}{l}\operatorname{der}\left(11 q^{+}\right) \\
21 p^{+}, \operatorname{der}(X) t(X ; 10)(p \mid 1 ; p 1)\end{array}$ \\
\hline SW480 NEOI2 & 10 & $-X$ & $\operatorname{del}(3)(q 13), i(15 q)$ \\
\hline
\end{tabular}

In SW480 CO5, three new structurally rearranged chromosomes were present in all cells. They were most probably derived from chromosomes 11, 21, and X. Furthermore, $\operatorname{der}(20) \mathrm{t}(5 ; 20)(\mathrm{q} 2 ; \mathrm{pl} 1 \mathrm{l})$, already present in SW480, was duplicated. Loss of chromosome $13 \mathrm{p}+$ was observed. 
After transfection with the $\mathrm{SSV}_{2}$ neo plasmid, SW480 NEO12 contained two additional abnormal chromosomes, a del(3)(q?1) and an $\mathrm{i}(15)(\mathrm{q} 2$ ?) in all cells. Furthermore, an $\mathrm{X}$ chromosome had been lost (Table 2). The clonal abnormalities in the transfected cell lines were also present twice in liypertetraploid cells.

Various additional clonal chromosome abnormalities, not observed in alI cells, were observed in all transfected cell lines; e.g. the cell line SW480 EJ2 demonstrated a.o. a $\operatorname{der}(4) t(4 ; ? 5)(\mathrm{p} 16 ; ? \mathrm{q})$ in four of 14 cells and an $\operatorname{add}(4)(\mathrm{pl} ?)$ with a $\operatorname{der}(\mathrm{X}) \mathrm{t}(\mathrm{X} ; 4)(\mathrm{p} 22.3 ; \mathrm{q}$ ?) in seven of 14 cells (Fig. 1$)$,

\subsubsection{Chomosome integration sites}

The chromosome integration sites in SW480 cells transfected with Ras-containing plasmids were predominantly identified in new structurally rearranged chromosomes (Table 3). The visually observed intensity of the hybridization signal (Figs. 2, 3) appeared to vary along with the level of expression of c-Ha-ras mRNA and may reflect the number of integrated plasmid copies.

SW480 EJ1 showed one integration site in a marker chromosome, MI. SW480 EJ2 showed chromosome integration of $\mathrm{pSV}_{2}$ neoEJ in the telomeric region of the $\mathrm{p}$-arm of a $\operatorname{der}(4) t(4 ; ? 5)(\mathrm{p} 16 ; ? \mathrm{q})$ (Fig, 2), and at the translocation breakpoint of a $\operatorname{der}(\mathrm{X}) \mathrm{t}(\mathrm{X} ; 4)(\mathrm{p} 22.3 ; \mathrm{q}$ ?) chromosome (Fig. 3)(30). SW480 EJ4 integration sites were observed in two different structurally abnormal chromosomes as well. One was identified as $15 \mathrm{pt}$, already present in the parental SW480 cell line; the second was a $\operatorname{der}(7) t(1 ; 7)(\mathrm{q} 2 ; \mathrm{q} 22)$, in which integration was observed at the translocation break-point (Fig. 3). SW480 EJ6 showed a chromosome integration site in a cytogenetically normal chromosome 11. Integration of the wild type c-Ha-ras gene in SW480 CO5 was observed in two different, structurally abnormal chromosomes. One chromosome was identified as a newly formed add(16)(q24) (Fig. 3); the other was one of the duplicated $\operatorname{der}(20) \mathrm{t}(5 ; 20)(\mathrm{q} 2 ; \mathrm{p} 11)$ chromosomes. Both chromosomes showed two integration sites, near each other, at the translocation breakpoint. Integration of $\mathrm{PSV}_{2}$ neo in $\mathrm{SW} 480$ NEO12 was identified in the centromeric region of a chromosome 16 with a normal appearance (Table 3).

Three of five integration sites in new structurally rearranged chromosomes occurred at translocation breakpoints, which involved telomeric bands, suggesting preferential integration at these regions. Integration was observed twice in subbands with known fragile sites (Table 3), and thus was not associated with fragile sites, when the number of known fragile sites (35) and subbands is considered: 107 and 321, respectively.

\subsubsection{Karyotypic instability}

The karyotypic abnormalities in SW480- and SW480-transfected cell lines, present in all cells (Fig. 1, Table 2), indicate that these cell lines originated from a single progenitor cell, and they were not considered a result of genetic instability. Only clonal chromosome abnormalities not observed in every cell, such as the 


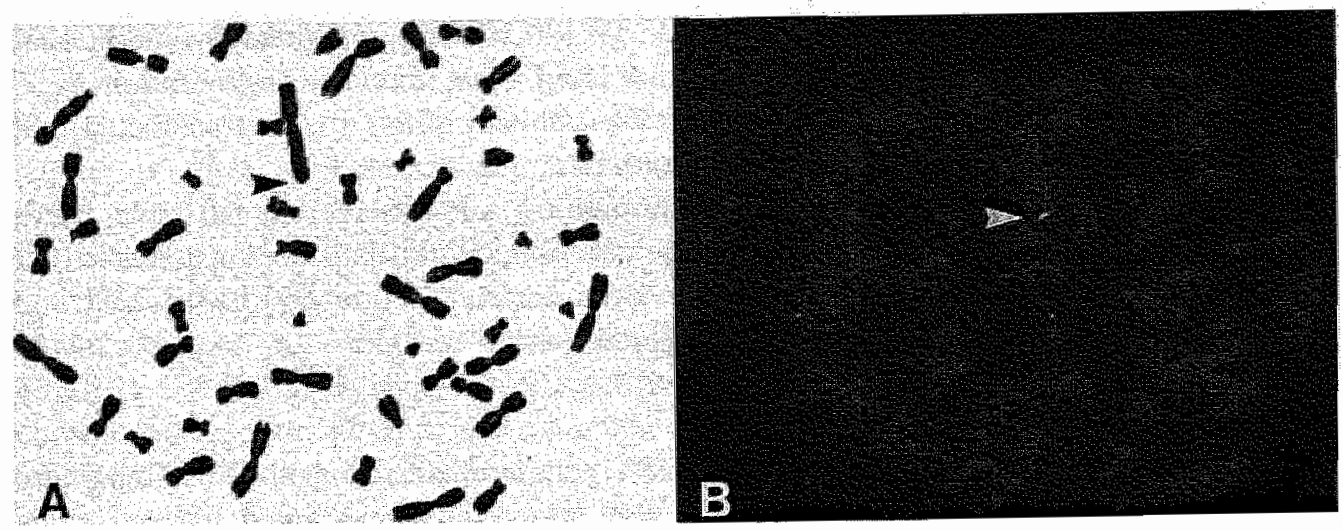

Figure 2. Combination of hot banding and fluorescence in situ hybridization (FISH).

A. Metaphase of $\mathrm{SW} 480$ EI2 after hot banding; B. The same metaphase after FISH showing hybridization (arrow) in the telomeric region of the p-arm of $\operatorname{der}(4) t(4 ; ? 5)(\mathrm{p} 16 ; ? \mathrm{q})$. Bar $=10 \mu \mathrm{m}$.

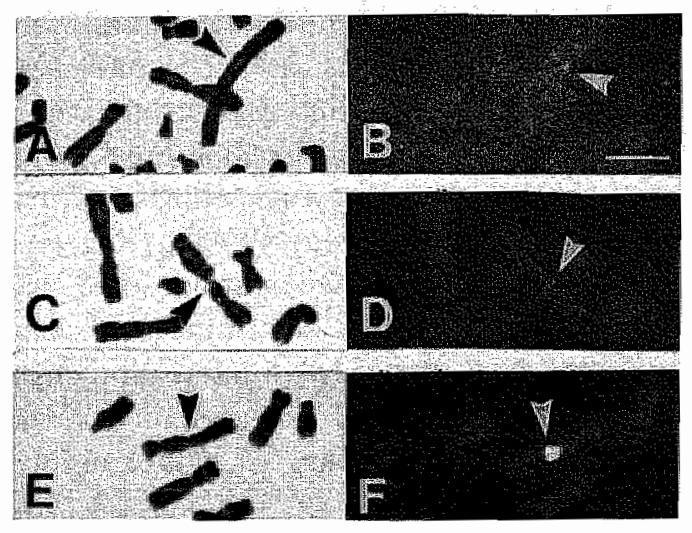

Figure 3. Intensity of furescence in situ hybridization signals.

A. C, and E. Banded chromosomes;

B, D, and F. Same metaphases alter FISH of SW480 EJ2, $\operatorname{der}(X) t(X ; 4)(p 22.3 ; q ?)$ $(A, B) ; \quad S W 480 \quad E J 4, \quad \operatorname{der}(7) t(1 ; 7)(q 2 ; \mathrm{q} 22)$ (C,D); SW480 COS, add(16)(q24) (E,F). Photomicrographs show partial metaphases containing the hybridization signals indicated by artows. Bar $=10 \mu \mathrm{m}$.

$\operatorname{der}(4) t(4 ; 75)(\mathrm{pl} \mathrm{16;?q)}$ in four of 14 SW480 EJ2 cells, were considered indicative of genetic instability because genetic alterations, not present in every cell, implied that these alterations occurred after selection. The number of these clonal genetic alterations, together with the number of non clonal changes, reflects the genetic instability of a cell line. To compare the genetic instability between cell lines, the karyotypic instability (Table 1) was determined.

The number of all clonal chromosome abnormalities not observed in every cell and all non clonal chromosome abnormalities in 10 SW480 cells was 14, all shown in Table 4. Thus, the karyotypic instability was 1.4 . 
Table 3. Chromosomal integration sites in transfected cell limes and nearest fragile sites.

\begin{tabular}{|c|c|c|c|c|}
\hline Cell line & $\begin{array}{l}\text { Integration in } \\
\text { chromosome }\end{array}$ & $\begin{array}{l}\text { Present } \\
\text { in } \$ W 480\end{array}$ & $\begin{array}{l}\text { Integration } \\
\text { in band }\end{array}$ & $\begin{array}{l}\text { Nearest } \\
\text { fragile site }\end{array}$ \\
\hline SW480 ENI & $\mathrm{MI}$ & No & $?$ & $?$ \\
\hline \multirow[t]{2}{*}{ SW480 EN2 } & $\operatorname{der}(X) t(X ; 4 ?)(p 22.3 ; q ?)$ & No & $\mathrm{Xp}_{\mathrm{p} 223}$ & $x p 22.3$ \\
\hline & $\operatorname{den}(4) t(4 ; 75)(p \mid 6 ; 9 q)$ & No & oth & $?$ \\
\hline \multirow[t]{2}{*}{$\mathrm{SW} 480 \mathrm{EJ} / 4$} & $\operatorname{der}(7)(1 ; 7)\left(q^{2} ; q 22\right)$ & No & $7 q 22$ & $7 \mathrm{q}_{22}$ \\
\hline & $15 p^{+}$ & Yes & $15 q 15$ & $15 q 22$ \\
\hline SW480 EJ6 & 11 & Yes & $11 q_{21}$ & 11914.2 \\
\hline \multirow[t]{2}{*}{ SW480 COS } & $\operatorname{add}(16)\left(q^{24}\right)$ & No & $16 \mathrm{q}_{24}$ & $16 \mathrm{q} 23.2$ \\
\hline & $\operatorname{der}(20) t(5 ; 20)(q 22 ; p 13)$ & Yes & $20 p 13$ & $20 \mathrm{p} 12.2$ \\
\hline SW480 NEO 12 & 16 & Yes & $16 q 12$ & $16 q 22.1$ \\
\hline
\end{tabular}

a. Hecht et al. [35].

b. Integration was observed in the telomeric region.

Table 4. Chromosomal abnormalities in SW480 cells observed infrequently $(n=10)$.

\begin{tabular}{llcc}
\hline Numerical & \multicolumn{1}{c}{ Structural } & Markers & Frequency \\
\hline$+13,+14$ & $1 q-, 2 q-, 3 q-, 6 q-$ & 1 & $1 / 10$ \\
& $18 q+, \operatorname{der}(19),(1 ; 19)$ & 2 & $1 / 10$ \\
$-13 p+,-21$ & $8 p-$ & & $2 / 10$ \\
\hline
\end{tabular}

Karyotypic instability was higher in the cell lines with increased expression of c-Ha-ras mRNA after transfection with $\mathrm{pSV}_{2}$ neoEJ. The significant increase in karyotypic instability of SW480 EJl was due predominantly to the presence of large marker chromosomes, which varied in number between one and five. The increase in karyotypic instability in SW480 EJ2 was due mainly to numerical and structural chromosome changes. Neither SW480 EJ4 nor SW480 EJ6 exhibited enhanced karyotypic instability, nor was karyotypic instability increased in SW480 CO5 and SW480 NEO12.

\subsection{DISCUSSION}

Our line of SW480 was cytogenetically slightly different from what has been reported in the literature $(33,34)$. The observed chromosome differences most likely represent ongoing karyotypic evolution in an unstable genome. Clonal selection after transfection of SW480 with the c-Ha-ras oncogene, the wild-type c-Ha-ras gene, and $\mathrm{pSV}_{2}$ neo resulted in cell lines with new chromosome changes, present in all cells. Such genetic alterations may explain the occasional metastatic ability of control transfectants $(36,37)$, and also may contribute to metastatic capacity after v-Ha-ras oncogene transfection (15). 
It was surprising that five of eight integration sites were localized on new rearranged chromosomes, not observed in SW 480, after transfection with Ras-containing plasmids. Integration of transfected plasmid DNA in new structurally rearranged chromosomes was reported previously $(38,39)$. In addition, integration of viruses such as hepatitis $B$ is commonly associated with a chromosome rearrangement at or near the site of integration $(40,41)$. An explanation for the preferential occurrence of integration sites in new rearranged chromosomes may be that the chromosomes bearing integration sites become unstable at the site of integration after random integration into the transfected genome, leading to new chromosome rearrangements with the integrated DNA at the rearranged site. An unstable region may evolve after integration of plasmid DNA in a telomeric band, disrupting the telomeric structure, which is essential for the stability of chromosomes $(42,43)$, and leading to highly fusogenic chromosome regions involved in new rearrangements. Such a mechanism is supported by our observations, because three out of five integration sites in new rearranged chromosomes occurred at or near translocation breakpoints involving telomeric bands.

We did not observe chromosome integration sites in SW480 limited to specific regions (i.e. fragile sites), which contrasts with preferential integration of the c-Ha-ras oncogene in the long arm of chromosome 3 in rat embryo fibroblasts, as reported by McKenna et al. (20). There may be two reasons for the different results. First, the selection procedure should be considered, because McKenna et al. (20) selected morphologically altered fibroblasts after transfection whereas we selected transfected cells on the basis of G418-resistance. Second, the process of integration may differ between transformed human cells and untransformed rodent cells.

The presence of new clonal abnormalities in all cells after transfection should be considered the result of experimental interference with the genome of a karyotypically instable cell and as such should not be considered evidence of increased genetic instability. Therefore, we chose to determine the karyotypic instability of a cell line as a measure of the genetic instability. Control transfection with $\mathrm{pSV}_{2}$ neo did not yield increased karyotypic instability, which suggest that the transfection procedure is not an important factor, although the number of cell lines studied was limited. Neither did karyotypic instability increase in SW480 CO5, despite the high level of c-Ha-ras mRNA in this cell line. Indeed, increased karyotypic instability was found only in two c-Ha-ras oncogene-transfected cell lines, SW480 EJl and SW480 EJ2, both with moderately increased levels of $c$-Ha-ras mRNA. This finding suggests that the increased karyotypic instability, a measure for the genetic instability, may be a c-Ha-ras oncogene-specific effect.

How the c-Ha-ras oncogene might induce karyotypic instability is not clear. In general, karyotypic instability may result from chromosome non disjunction and mitotic recombination. This might be caused by incorrect segregation of chromosomes during mitosis or by the precocious entering of a dividing cell into mitosis. The correct segregation of chromosomes during mitosis requires topoisomerase II (44). Onset to mitosis is regulated by the activity of the M-phase-promoting factor (45). The activity 
of both proteins was recently shown to be altered after introduction of the c-Ha-ras oncogene into the cell $(46,47)$. In c-Ha-ras oncogene-transformed NIH/3T3 cells, the activity of topoisomerase II is higher than in normal NIH/3T3 cells, in a form that appears to be less dependent on the proliferative state of cells (46). Xenopus oocytes injected with c-Ha-ras oncogene mRNA demonstrated a high level of $M$-phasepromoting factor activity, specifically induced by the oncogenic form of the c-Ha-ras gene (47). Furthermore, allelic overrepresentation of the c-Ha-ras oncogene has been associated with progression of skin tumors in mouse models $(48,49)$. Non disjunction and mitotic recombination events in these models may have led to overrepresentation of the c-Ha-ras oncogene (49) or to complete loss of the normal c-Ha-ras gene (48). Non disjunction and mitotic recombination were observed only in tumors with activated ras genes (48). Therefore, interaction of the c-Ha-ras oncogene with topoisomerase II or MPF activity might disturb mitosis or onset to mitosis, resulting in chromosome non disjunction and incorrect chomosome segregation and, in turn, increased karyotypic instability.

We showed that transfection of SW 480 cells with the c-Ha-ras oncogene results in increased c-Ha-ras mRNA expression and enhanced karyotypic instability. This finding suggests that not only expression of the oncogene, but also the acquired genotypic instability might be responsible for acquisition of the metastatic phenotype. Furthermore, identification of chromosome integration sites showed predominant integration of Ras-containing plasmids in structurally rearranged chromosomes of SW480. Finally, integrations were observed especially associated with breakpoints in telomeric bands. 


\subsection{REFERENCES}

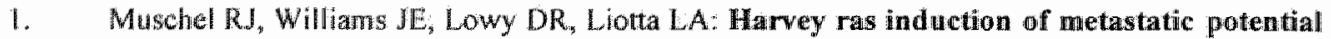
depends upon oncogene activation and the type of recipient cell. Am. J. Pathol. 1985; 121: $1-8$.

2. Egan SE, MoClanty GA, Jarolim L, et al Expression of H-ras correlates with metastatic potential: evidence for direct regulation of the metastatic phenotype in $10 \mathrm{~T} 1 / 2$ and NIH 3 T3 calls. Mol. Cell. Biol 1987; 7: 830-837.

3. Bradley $M O$, Kraynak $A R$. Storer $R D$, Gibbs $J B$. Experimental metastasis in nude mice of NII 3 T3 cells containing various ras genes. Proc. Natl. Acad. Sci. U. 5. A. 1986; 83: $5277-5281$.

4. Thorgeirsson UP, Turpeennemi-Hujanen T, Williams $\mathbb{N E}$, el al: NIH/3T3 cells transfected with human tumor DNA containing activated ras oncogenes express the metastatic phenotype in nude mice. Mol. Cell. Biol. 1985; 5: 259-262.

5. Garbisa $\mathrm{S}$ "Pozzatti $\mathrm{R}$, Muschel $\mathrm{R}$, ei al: Secretion of type IV collagenolytic protease and metastatic phenotype: induction by transfection with c-Ha-ras but not c-Ha-ras plus Ad2-E1a. Cancer. Res. 1987; 47: 1523-1528.

6. Collier $\| \mathrm{E}$, Withelm $\mathrm{SM}$, Eisen $\mathrm{AZ}$, et al: H-ras oncogene-transformed human bronchiall epithelial cells (TBE-1) secrete a single metalloprotease capable of degrading basement membrane collagen. J. Biol Chem. 1988; 263: 6579-6587.

7. Testa JE, Medcalf RL, Cajot JF, Schleuning WD, Sordat B: Urokinase-type plasminogen activator biosynthesis is induced by the E.J-Ha-ras oncogene in CL26 mouse colon carcinoma cells. Int. J. Cancer. $1989 ; 43: 816-822$.

8. Brunner G, Pohl J, Erkell LJ, Radler-Pohl A, Schirmacher V: Induction of urokinase activity and malignant phenotype in bladder carcinoma cells after transfection of the activated Ha-ras oncogene. J. Cancer. Res. Clin. Oncol. 1989; 115: 139-144.

9. Bernhard EJ, Muschel RJ, Hughes EN: Mr 92,000 gelatinase release correlates with the metastatic phenotype in transformed rat embryo cells. Cancer. Res. 1990; 50:3872-3877.

10. Theodorescu D, Cornil I, Sheehan C, Man MS, Kerbel RS: Ha-ras induction of the invasive phenotype results in up-regulation of epidermal growth factor receptors and altered responsiveness to epidermal growth factor in human papillary transitional cell carcinoma cells. Cancer. Res. 199 I; 51: 4486-4491.

11. Klein $\mathrm{G}$, Klein $\mathrm{E}$ : Conditioned tumorigenicity of activated oncogenes. Cancer. Res. 1986; 46: $3211-3224$.

12. Pratt $\mathrm{Cl}$, Kao $\mathrm{CH}$, Wu SQ, Gilchrist $\mathrm{KW}$, Oyasu R, Reznikoff CA: Neoplastic progression by EJ/ras at different steps of transformation in vitro of human uroepithelial cells. Cancer. Res. 1992; 52: 688-695.

13. Bardwell L: The mutagenic and carcimogenic effects of gene transfer. Mutagenesis. 1989; 4: $245 \times 253$.

14. Ichikawa T, Kyprianou N, Isaacs JT: Genetic instability and the acquisition of metastatic ability by rat mammary cancer cells following $\mathrm{v}$-H-ras oneogene transfection. Cancer. Res. 1990; $50: 6349-6357$.

15. Ichikawa $T$, Schalken JA, lchikawa $Y$, Steinberg GD, Isaacs JT: H-ras expression, genetic instability, and acquisition of metastatic ability by rat prostatic cancer cells following v-H-ras oncogene transfection. Prostate. 1991; 18:163-172.

16. Hurlin PJ, Maher VM, McCormick JJ: Maligmant transformation of human fibroblasts caused by expression of a transfected T24 HRAS oncogene. Proc. Natl. Acad. Sci. U. S. A. 1989;86:187-191. 
17. Cooper $\mathrm{GM}_{\mathrm{s}}$ ed: Oncogenes. first ed. Boston: Jones and Barthet Publishers; 1990

18. Wang $J$, Chenivesse $X$, Henglein $B$, Brechot $C$ : Aepatitis $B$ virus integration in a cyclin $A$ gene in a hepatocellular carcinoma. Nature. $1990 ; 343: 555-557$.

19. Hunter T, Pines J: Cyclins and cancer. Cell. 1991; 66: 1071-1074.

20. McKenna WG, Nakahara $K$, Muschel RJ: Site-specific integration of $\mathbf{H}$-ras in transformed rat embryo cells. Science. 1988; $241: 1325-1328$.

21. Leibovitz A, Stinson JC, McCombs WB, et al: Classification of human calorectal adenocarcinoma cell lines. Cancer Research 1976; 36: 4562-4569.

22. Southern PJ, Berg P: Transformation of mammalian cells to antibiotic resistance with a bacterial gene under control of the $\mathbf{S V} 40$ early region promoter. J. Mol. Appl. Genet. 1982; 1: $327-341$.

23. Capon DJ, Chen EY, Levinson AD, Seeburg PH, Goeddel DV: Complete nucleotide sequences of the T24 human bladder carcinoma oncogene and its normal homologue. Nature. $1983 ; 302: 33-37$.

24. Parada LF, Tabin CJ, Shih C, Weinberg RA: Human EJ bladder carcinoma oncogene is homologue of Harvey sarcoma virus ras gene. Nature. 1982; 297; 474-478.

25. Sambrook J, Fritsch EF, Maniatis T: Molecular cloning. second ed. New York: Cold Spring Harbor Laboratory Press, 1989

26. Graham FL, van der Eb AJ: A new technique for the assay of infectivity of human adenovirus 5 DNA. Virology $1973 ; 52: 456467$.

27. Chen $\mathrm{C}$, Okayama H: High-efficiency transformation of mammalian cells by plasmid DNA. Mal. Cell. Biol. 1987; 7: 2745-2752.

28. Mitelman F, ed: ISCN (1991): Guidelines for Cancer Cytogenetics, Supplement to An International System for Human Cytogenetic Nomenclature. Basel: Karger, S, 199]

29. Garson JA, wan-den-Berghe JA, Kemshead JT: Novel non-isotopic in situ hybridization technique detects small ( $1 \mathbf{K b})$ unique sequences in routinely G-banded human chromosomes: fine mapping of N-myc and beta-NGF genes. Nacleic. Acids. Res. 1987; 15: $4761-4770$.

30. de Vries JE, Kornips FHAC, Wiegant J, et al: Chromosomal localization of transfected genes: by a combination of hot banding and fuorescence in situ hybridization. J. Histochem. Cytochem. 1992; 40: 1053-1058.

31. Klever M, Grond-Ginsbach $C$, Scherthan H, Schroeder-Kurth TM: Chromosomal in situ suppression hybridization after Giemsa banding. Hurm. Genet. 1991; 86: 484-486.

32. Wiegant $J$, Galjart $N J$, Raap $A K$, d'Azzo A: The gene encoding human protective protein (PPGB) is on chromosome 20. Genomics. 1991; 10:345-349.

33. Cherif D, Le-Coniat M. Suarez HG, Bernheim A, Berger R: Chromosomal localixation of amplified c-myc in a human collon adenocarcinoma cell line with a biotinylated probe. Cancer. Genet. Cytogenet. 1988; 33: 245-249.

34. Yaseen NY, Watmore AE, Potter AM, Potter CW Jacob $\mathrm{G}$, Rees RC: Chromosome studies in eleven colorectal tumors. Cancer. Genet. Cytogenet. 1990; 44: 83-97.

35. Hecht F, Ramesh $\mathrm{KH}$, Lockwood DH: A guide to fragile sites on human chromosomes. Cancer. Genet. Cytogenet. 1990; 44: 37-45.

36. Kerbel RS, Waghome C, Man MS, Elliott B, Breitman ML: Alteration of the tumorigenic and metastatic properties of neoplastic cells is associated with the process of callium phosphate-mediated DNA transfection. Proc. Natl. Acad. Sci. U. S. A. 1987; 84: 1263-1267.

37. Bell C, Frost $P$, Kerbel RS: Cytogenetic heterogeneity of genetically marked and metastatically competent "dominant" tumor cell cllones. Cancer. Genet. Cytogenet. 1991; 54 : $153-161$. 
38. Robins DM, Ripley $\mathrm{S}$. Henderson $\mathrm{AS}$. Axel R: Transforming $\mathrm{DNA}$ integrates into the bost genome. Cell. 1981; 23:29-39.

39. Popescu $N C$. DiPalo JA: Infegration of human papillomavirus 16 DNA and genomic rearrangements in immortalized human keratinocyte lines. Cancer. Res. 1990; 50: $1316-1323$.

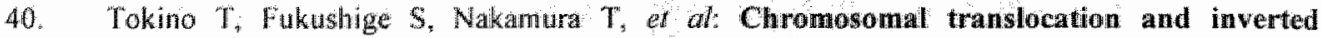
duplication associated with integrated hepatitis $\mathbf{B}$ virus in thepatocellular carcinomas. $J$. Virol. $1987 ; 61: 3848-3854$.

41. Henderson $A S$, Lipley $\$$. Hino 0 , Rogler CE. Identification of al chromosomal aberration associated with a lrepatitis B DNA integration site in human cells. Cancer. Genet. Cytogenet. 1988:30:269-275.

42. Greider CW: Chromosome first aid. Cell. 1991; 67: 645-647.

43. Hecht F, Hecht BK: The telomere in cancer. Cancer. Genet: Cytogenet. 1991; 54: $245-246$.

44. Holm $\mathrm{C}$, Goto $\mathrm{T}$, Wang JC, Botstein D: DNA topoisomerase II is required at the time of mitosis in yeast. Cell. $1985 ; 41: 553-563$.

45. Lohka MJ, Hayes MK, Maller JL: Purification of maturation-promoting factor, an intracellular regulator of early mitotic events. Proc. Matl. Acad. Sci. U. S. A. 1988; 85; 3009-3013.

46. Woessner RD, Chung TD, Hofmann $G A$, et $a$ : Differenees between normal and ras-transformed NIH-3T3 cells in expression of the $170 \mathrm{kD}$ and $180 \mathrm{kD}$ forms of topoisomerase II. Cancer. Res. 1990; 50: 2901-2908.

47. Daar I, Nebreda AR, Yew $N$, et al: The ras oncoprotein and M-phase activity. Science. 1991; 253: 74-76.

48. Bremner $R$, Balmain A: Genetic changes in skin tumor progression: correlation between presence of a mutant ras gene and loss of heteroxygosity on mouse chromosome 7. Cell. 1990; $61: 407-417$.

49. Bianchi $\mathrm{AB}$, Aldaz $\mathrm{CM}$, Conti $\mathrm{CJ}$ : Non random duplication of the chromosome bearing a mutated Harras-1 allele in mouse skin tumors. Proc. Natl. Acad. Sci. U. S. A. 1990; 87: $6902-6906$ 


\section{CHAPTER 5}

\section{PHENOTYPIC ANALYSIS OF CACO 2 AND SW480 CELL LINES TRANSFECTED WITH THE C-HA-RAS ONCOGENE}

J.E. de Wries, M. van Driel, P. Marx, E.P.M. van der Linden, L. de Bruin, P.M. Moerkerk, H.W. Verspaget, F.T. Bosman, and J. ten Kate.

Parts of this chaprer have been submitted for publication. 


\subsection{INTRODUCTION}

It has been firmly established that oncogenes play a significant role in the disregulation of cellular growth and differentiation, which characterizes neoplasia (1). The family of the ras genes, encoding the highly similar, $\mathrm{N}$-, $\mathrm{Ki}$ - and Ha-ras proteins, was among the first to be identified (2-4). It has been suggested that the normal $\mathrm{c}-\mathrm{N}-, \mathrm{c}-\mathrm{Ki}-$, and $\mathrm{c}-\mathrm{Ha}-$ ras genes may serve different functions, but when activated, the functional difference might be lost (5). This is supported by the induction of tumorigenic and invasive behavior in human immortal fibroblast MSU 1.1 cells after transfection with activated oncogenic forms of either the $\mathrm{N}$, Ki- or Ha-ras gene (6-8). However, activation of cKi-ras and c-Ha-ras proteins is catalyzed by different Guanine Nucleotide Releasing Proteins (9). These proteins convert inactive GDP-bound p21ras proteins into active GTP-bound p2lras proteins (10). Therefore, the protein products of the c-Ki-ras and cHa-ras oncogenes may exert different effects depending on the Guanine Nucleotide Releasing Protein available in the recipient type of cell. It is supported by the observation that c-Ha-ras oncogene transfection increases the genetic instability in SW480 cells (11), which contain a c-Ki-ras gene with a pointmutation in codon 12 (12). The frequent observation that many different human tumor types contain pointmutated c-ras genes, has suggested that oncogenic c-ras genes are involved in carcinogenesis. The presence of pointmutated c-ras genes, especially c-Ki-ras, in about $50 \%$ of human colorectal adenomas and carcinomas $(5,13)$ is one of the findings that has led to a genetic model of colorectal carcinogenesis, in which pointmutations in the c-ras genes are considered as early events, putatively playing a role in the transition from adenoma to carcinoma (14). This model has been based primarily on observational studies of series of colorectal adenomas and carcinomas. Additional supportive evidence might be provided by transfection studies, in which the effects of the introduction of pointmutated ras genes can be investigated.

Colorectal carcinoma cell lines have been used infrequently to investigate the effect of the introduction of pointmutated ras oncogenes. Studies indicate that the c-Ha-ras oncogene increased expression of differentiation markers $(15,16)$ and upregulated $\mathrm{u}-\mathrm{PA}$ biosynthesis (17). Increased biosynthesis of u-PA has been associated with acquisition of invasive capacity of tumor cells (18-22) and might therefore be an important event in the progression towards invasion and metastasis (23). On the other hand, increased expression of differentiation markers is suggestive for a higher degree of differentiation, which is inversely related to malignancy.

In view of these contrasting reports on the effects of overexpression of the c-Ha-ras oncogene on colorectal carcinoma cells we transfected the c-Ha-ras oncogene, pointmutated in codon 12 (24), into the human colorectal carcinoma cell lines $\mathrm{CaCo} 2$ (25), which is highly differentiated and non-tumorigenic (26-28), and SW480 (29), which is poorly differentiated, tumorigenic but non-invasive and non-metastatic in vivo (Chapter 2) to study the effects of the c-Ha-ras oncogene on differentiation, tumorigenic capacity, and invasive potential. The effect on differentiation was determined by 
detecting the expression of differentiation markers specific for colonic epithelium, which included sucrase-isomaltase, chromogranine $A$ and the production of mucin ( 30 ). The effects on tumor progression was analyzed by in vivo growth characteristics, invasion into embryonic chick heart fragments, in vitro production of the proteases t-PA and $\mathrm{u}-\mathrm{PA}$ and gelatinase activity (31), the expression of the cell adhesion molecule Ecadherin and integrin receptors. The potential doubling time was determined as a measure for the proliferative potential $(32,33)$.

The results indicate that the $\mathrm{c}-\mathrm{Ha}$-ras oncogene might confer tumorigenic potential along with proteolytic activity to $\mathrm{CaCo} 2$ cells, but does neither induce invasive behavior in vivo nor affect the degree of differentiation, the expression of cell adhesion molecules and the proliferative potential of CaCo 2 and SW480 cells.

\subsection{MATERIALS AND METHODS}

\subsubsection{Cell culture and transfection.}

CaCo 2 (25) and SW480 cells (29) were cultured in DMEM with 5\% Fetal Calf Serum (Boehringer, Mannheim, Germany) at $37^{\circ} \mathrm{C}$ in a humidified atmosphere with $5 \% \mathrm{CO}_{2}$. The plasmid $\mathrm{pSV}_{2}$ neo (34) contains the neomycin gene, which provides resistance to the antibiotic gentamycin. The plasmid $\mathrm{pSV}_{2}$ neoEJ contains a $6.6 \mathrm{~kb}$ genomic Bam HI fragment of the c-Ha-Ras oncogene with a $G$ to $T$ transversion in codon 12 (24), $\mathrm{pSV}_{2}$ neoCO contains the 6.6 genomic Bam HI fragment of the wild type c-Ha-Ras gene (2), kindly provided by Dr. Cerutti (Swiss Institute for Experimental Cancer Research, CH-1066 Epalinges, Switzerland). Plasmids were isolated with the alkaline lysis method (35) and further purified by precipitation with $\mathrm{NH}_{4} \mathrm{Ac}(7.5 \mathrm{M})$.

Cells were transfected with the calcium phosphate precipitation technique (36), as modified by Chen and Okayama (37). The addition of the plasmid/ $\mathrm{CaCl}_{2}$ mixture to N.N-bis(2-hydroxyethyl)-2-aminoethane-sulfonic acid(BES) buffered saline, was carried out in continuous airflow.

Cell lines were established using two procedures. For the first procedure, the cells were plated after transfection into 96 wel॥ plates, and selection was started by adding G418 $(800 \mu \mathrm{g} / \mathrm{ml}$, GIBCO, Gaithersburg, USA) to the culture medium. After three weeks, selection was completed and colonies started to grow in 96 well plates. This procedure yielded the cell lines $\mathrm{CaCo} 2 \mathrm{EJI-EJ} / 2$ and $\mathrm{SW} 480 \mathrm{EJ} 1,2,4$. In the alternative procedure, two days after transfection cells were transferred into $75 \mathrm{~cm}^{2}$ culture flasks and selection was started ( $\mathrm{G} 418,800 \mu \mathrm{g} / \mathrm{ml}$ ). Untransfected cells were no longer viable after three weeks and colonies of transfected cells started to grow. These were trypsinized and plated in 96 well plates by limiting dilution and yielded the cell lines CaCo 2 CO1-3, NEO1-5, and SW480 EJ3, 5-24, CO1-6, NEO1-16. All cell lines were obtained from wells with only one colony. 


\subsubsection{Southern and northern blotting.}

Chromosomal DNA was isolated after lysis of cells with $1 \%$ SDS in the presence of proteinase $\mathrm{K}$ (Boehringer), extracted with phenol/chloroform mixture and precipitated with ethanol (35). It was digested with Bam HI (Boehringer), blotted on nylon filter and hybridized with the 3.8 Pvull $\mathrm{kb}$ fragment of $\mathrm{pSV}_{2}$ neo, or with the $3.0 \mathrm{~kb}$ Sacl fragment of the wild type c-Ha-ras gene, containing the four coding sequences. Both probes were labeled with ( $\left.{ }^{32} \mathrm{P}\right) \mathrm{dCTP}$ (Amersham) by random priming.

Cytoplasmic mRNA was isolated from cells lysed with NP40 in the presence of vanadyl ribonucleoside complex. Nuclei were pelleted and discarded. The supernatant was extracted with phenol/chloroform mixture and mRNA was precipitated with ethanol (35). After gelelectrophoresis and blotting on nylon filter, it was hybridized with the 3.0 $\mathrm{kb}$ Sacl fragment of the wild type c-Ha-ras gene, labeled with $\left({ }^{32} \mathrm{P}\right) \mathrm{dCTP}$ (Amersham) by random priming. Hybridization signals were scanned with a densitometer (LKB Ultrascan XI, Uppsala, Sweden). The transfected cell lines were compared with the parental cell line, for which the hybridization signal was arbitrarily set to unity. Differences caused by unequal loading of mRNA were corrected for by hybridization with a probe specific for actin.

\subsubsection{Xenografting.}

Athymic CD-1 male nude mice, 3-4 weeks old, were obtained from Charles River Wiga (Freiburg, Germany) and maintained in a laminar air flow cabinet under specific pathogen free conditions.

Tumor cells were injected in nude mice under ether anesthesis, at four sites in the subcutis or in the cecal wall, which was approached through a small median abdominal incision, with $1 \times 10^{6}$ cells in $0.1 \mathrm{ml}$ PBS. The mice were killed 7 weeks after injection. At autopsy, tumor tissue was removed and fixed in $4 \%$ formalin, embedded in paraplast for histology and immunohistochemical staining.

\subsubsection{Potential doubling time, $\mathrm{T}_{\text {por }}$.}

To determine the $T_{\text {ror }}$ of the cell lines in vitro, cells were cultured in the presence of 10 $\mu \mathrm{M}$ BrdU for $30 \mathrm{~min}$, washed three times with PBS and refed with $5 \mathrm{ml}$ culture medium $(t=0)$. The cells were harvested after $3 \mathrm{hr}$ by trypsinization, washed twice with PBS and fixed in 70\% ethanol for flow cytometry as described previously (38). The $T_{r o r}$ was determined according to White et al. (39).

\subsubsection{Protease assays.}

Near confluent cells were provided with fresh medium and after $24 \mathrm{~h}$ the amount of $\mathrm{u}$ PA and t-PA in medium and cellular extracts was measured by sandwich ELISA as described previously $(40,41)$. Protein content of the cell extracts was determined according to Lowry et al. (42). The variability between data of independent samples from one cell line ranged from $10 \%$ to $50 \%$. Intra sample variation did not exceed $3 \%$. 
Gelatinase activity was determined in serum free medium from near confluent cells, cultured in serum free medium $24 \mathrm{~h}$. before harvesting (43). Gels were run in a Biokad mini protean system. Gelatinase activity bands were visualized by negative Coomassie brilliant blue staining.

\subsubsection{Immunohistochemistry of cell adhesion molecules and differentiation markers.}

$\mathrm{CaCo} 2$ parental and transfected cells were cultured to confluency, whereupon medium was refreshed daily. Cells were harvested after two weeks. SW480 parental and transfected cells were cultured to near confluency, the medium was refreshed and the cells were harvested $24 \mathrm{~h}$ later. Cells, harvested by gentle scraping with a rubber policeman, were washed twice with PBS, diluted in PBS/1\% BSA and centrifuged on a glass slide. Methanol, $1 \mathrm{~min},-20^{\circ} \mathrm{C}$, followed by aceton, $3 \times 1 \mathrm{sec},-20^{\circ} \mathrm{C}$ was used for fixation. Endogenous peroxidase was blocked by incubation in $\mathrm{PBS} / \mathrm{H}_{2} \mathrm{O}_{2}(0.3 \%)$ for 20 min at RT, to detect cell adhesion molecules, or in methanol/ $\mathrm{H}_{2} \mathrm{O}_{2}(0.3 \%)$ in case of differentiation markers. Monoclonal antibodies used are listed in Table 1. Monoclonal antibody binding was detected with rabbit anti-mouse horse radish peroxidase conjugate (Dako, Glostrup, Denmark). Peroxidase activity was visualized with diaminobenzidine and imidazol. Slides were counterstained with hematoxylin. As negative controls, specific antibodies were omitted. Normal human colon mucosa was used as a positive control. The results of the immunocytochemistry were scored independently by two observers ( JdV, EvdL), providing largely concordant results. Photographs were taken with a Zeiss Axioplan (MC100).

Table 1. Monocllonal antibodies used.

\begin{tabular}{|c|c|c|c|}
\hline Specific for & Clone & Source & Reference \\
\hline E-cadherin & 659 & Eurodiagnostica" & 44 \\
\hline Integrin $\alpha_{2} \beta_{1}$ & $10 \mathrm{G} 11$ & A. Somnenberg. & 45 \\
\hline Integrin $\alpha_{y} B_{\sharp}$ & $J 43$ & A.P. Albino & 46 \\
\hline Integria $\alpha_{6} B_{1}$ & $\mathrm{GoH} 3$ & A. Sonnenberg & 47 \\
\hline Sucrase-isomaltase & HBB2/6"4/88 & H.-P. Haurii & 48 \\
\hline Mucin & Parlam 13 & Our department & 49 \\
\hline Chromogranine A & $\mathbb{L K} 2 \mathrm{H} \| \mathrm{O}$ & Sanbyo & 50 \\
\hline
\end{tabular}

a. Eurodiagnostica BV. Apelldoorn, The Netherlands.

b. Sambyo, Uden, The Wetherlands.

\section{$5.3 \quad$ RESULTS}

\section{Establishment of transfected cell lines}

Transfection of $\mathrm{CaCo} 2$ cells with the plasmids $\mathrm{pSV}_{2}$ neoEJ, $\mathrm{pSV}_{2}$ neoCO or $\mathrm{pSV}_{2}$ neo yielded 12,3 and 5 clonal cell lines, respectively. Transfection of SW480 cells with the 
same plasmids yielded 24,6 and 16 clonal cell lines, respectively. Southern blotting showed integration of plasmid DNA in all but one (CaCo EJ5) of the transfected cell lines, wach cell line demonstrating a unique pattern of restriction fragments (Fig. 1), indicative of integration of intact c-Ha-ras oncogene in CaCo 2 EJ3, EJ6, and EJ9, and in $\mathrm{SW} 480 \mathrm{EJ} 1$ and EJ2 cells. In $\mathrm{SW} 480 \mathrm{CO}$, but in none of the $\mathrm{CaCo} 2 \mathrm{CO}$ cell lines, we observed integration of intact wild type c-Ha-ras gene. Northern blotting revealed increased expression of c-Hatras mRNA in the cell lines CaCo 2 EJ6 (51) and SW480 EJ1, EJ2, and CO5 (Fig. 2, Table 2). The level of expression roughly corresponded with the amount of plasmid DNA detected in these clonal cell lines (11). This was taken as indirect evidence that the increase in c-Ha-ras mRNA was due to transcription of the transfected c-Ha-ras genes.

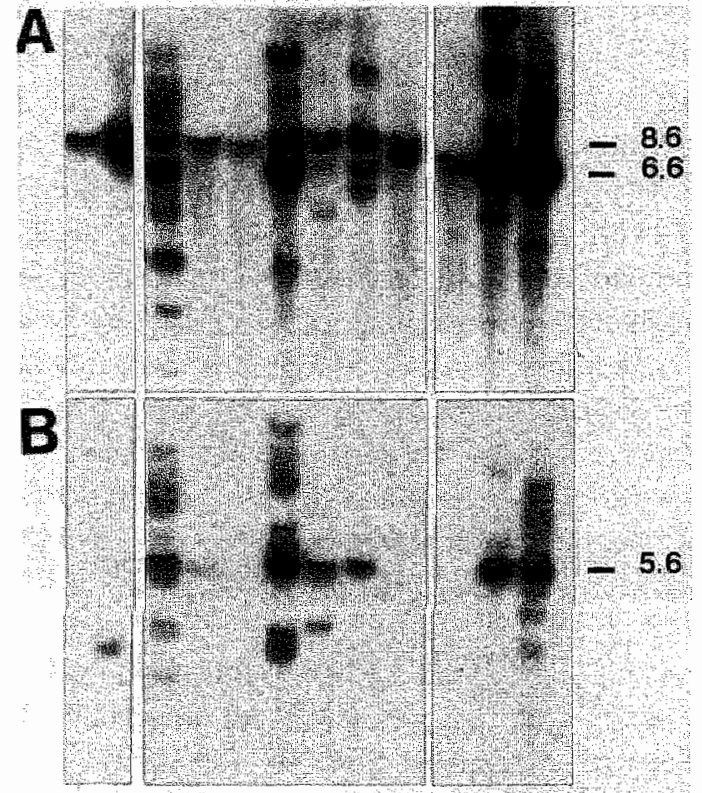

$12345 \quad 5 \quad 789.10,1112$

Figure 1. Integration of plasmid DNA in transfected cell lines.

A. Hybridization with the $3.0 \mathrm{~kb}$ Sacl fragment of the wild type c-Ha-ras gene. Note that the endogenous BamHll fragment of c-Ha-ras is 8.6 $\mathrm{kb}$ in $\mathrm{CaCo} 2$ and $6.6 \mathrm{~kb}$ in SW480. B. The same blot hybridized with the $3.8 \mathrm{~kb}$ Pvull fraginent of $\mathrm{pSV}_{2}$ neo. Note the $\mathrm{pSV}_{2}$ neo plasmid at $5.6 \mathrm{~kb}$ and the absence of specific hybridization in the $\mathrm{CaCO} 2$ and $\mathrm{SW} 480$ parental cell lines. Lanes contain $10 \mu g$ chromosomal DNA digested with BamHI. Lane 1: $\mathrm{CaCo} 2 ; 2: \operatorname{CaCo} 2 \mathrm{EJ} 1 ; 3: \mathrm{CaCo} 2 \mathrm{EJ} 2 ; 4$ : $\mathrm{CaCo} 2 \mathrm{EJ} 3 ; 5$ : $\mathrm{CaCo} 2 \mathrm{EJ} 5 ; 6: \mathrm{CaCo} 2 \mathrm{EJ} 6$;

7: $\mathrm{CaCo} 2 \mathrm{EJ} 7 ; 8$ : $\mathrm{CaCo} 2 \mathrm{EJ} 9 ; 9$ : $\mathrm{CaCo} 2$ EJ10; 10: SW480; 11: SW480 EJI 12: SW480 El2.

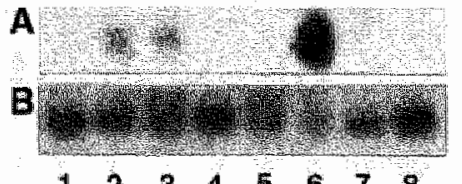

$\begin{array}{llllllll}1 & 2 & 3 & 4 & 5 & 6 & 7 & 8\end{array}$
Figure 2. Expression of c-Ha-ras mRNA in SW480 transfected cell lines.

A. Hybridization with the $3.0 \mathrm{~kb}$ Sacl fragment of the wild type c-Ha-ras gene. All lanes demonstrated expression of cHaras mRNA upon longer exposure times (not shown). Note the increased expression of c-Ha-ras mRNA in SW480 EJI

and SW480 EJ2 and the strong increased expression in SW480 CO5. B. The same blot hybridized with a. probe specific for actin. Lanes contain $10 \mu \mathrm{g}$ cytoplasmic mRNA. Lane $1: 5 W 480 ; 2:$ SW480 EJ1; 3 : SW480 El2; 4: SW480 EJ4; 5: SW480 EI17; 6: SW480 CO5; 7: SW480 NEO3; 8: SW480 NEOL2. 
A subset of transfected cell lines was further analyzed and included: (1) cell lines with increased expression of c-Ha-ras mRNA afer transfection with $\mathrm{pSV}_{2}$ neoEJ or $\mathrm{pSV}_{2}$ neoCO; (2) cell lines with unaltered expression of cuHa-ras mRNA after transfection with $\mathrm{pSV} \mathrm{V}_{2}$ neoEJ or $\mathrm{pSV}_{2} \mathrm{NEO}_{\text {; }}$ and (3) parental cell uines.

\section{Bellavior in nulnu mice and it witro inwasion assay}

$\mathrm{CaCo} 2 \mathrm{CaCo} 2$ cells were non-tumorigenic in xenograft experiments in the subcutis, as were the transfected $\mathrm{CaCo} 2$ cells, with the exception of $\mathrm{CaCo} 2 \mathrm{E} 36$ cells, which also demonstrated increased expression of c-Ha-ras mRNA after transfection with the c-Haras oncogene (Table 2). This cell line yielded moderately well differentiated non* invasive adenocarcinonas with strong focal mucin production (51). Both $\mathrm{CaCo} 2$ cells and $\mathrm{CaCo} 2 \mathrm{E} 66$ cells injected in the cecal wall of nu/nu mice did not develop primary tumors (Table 2).

Parental CaCo 2 cells did not invade embryonic chick heart fragments. In witro imvasive potential was not induced in c-Ha-ras oncogene transfected CaCo 2 EJ6 cells (Table 2). SW 480 . The cell line SW480 was tumorigenic in the subcutis and remained tumorigenic after transfection (Table 2). All cell lines grew as non-invasive adenocarcinomas with areas of solid growth, intra- and extracellular lumina and focal mucin production. SW480 EJ2 demonstrated increased nuclear pleomorphism and intra- and extracellular lumina were more extensive. SW480 cells injected in the cecal wall of nu/nu mice demonstrated a low take-rate, in contrast with previous experiments (Chapter 2). The take-rate of the transfected SW480 cell lines was even lower, primary tumors were not observed after orthotopic xenografting (Table 2).

The parental SW480 cell line invaded embryonic chick heart fragments. Invasive potential was also observed in c-Ha-ras oncogene transfected SW480 cell lines (Table 2).

\section{Morphology and potential doubling time}

CaCo 2. In vitro morphology of all $\mathrm{CaCo} 2$ transfected cell lines was identical to the parental $\mathrm{CaCo} 2$ cell line. The potential doubling time appeared to be prolonged significantly in the transfected cell lines, but the increase was not correlated with an enthanced level of c-Ha-ras mRNA (Table 2).

SW 480. Some of the transfected SW480 cell lines demonstrated morphological changes. In contrast with the spindle shaped form of parental SW480 cells, SW480 EI4 and SW480 NEO3 grew in closed monolayers, and some SW480 EJ cell lines, including SW480 EJ17, grew predominantly in suspension (not shown). The morphotypes were maintained after prolonged culture.

The potential doubling time of transfected SW480 cell lines was either similar to the parental SW480 cell line or elevated. It was increased significantly in SW480 EII and SW480 CO5 (Table 2). However, the increase in the potential doubling time did not correlate with an increased level of c-Ha-ras mRNA after transfection with the c-Ha-ras oncogene. 
Table 2. Level of cHa-rass mRNA, behavior in wivo and in vitro, and potential doubling time of parental and transfeeted cell lines.

\begin{tabular}{|c|c|c|c|c|c|}
\hline \multirow[t]{2}{*}{ Cell line } & \multirow{2}{*}{$\begin{array}{l}\text { C-Ha-ras } \\
\text { mRNA level }\end{array}$} & \multicolumn{2}{|c|}{ Nu/nu mice } & \multirow{2}{*}{$\mathrm{ECHF}^{2}$} & \multirow{2}{*}{$\begin{array}{l}T_{\text {FES }}(\mathrm{hr}) \\
\pm S_{\text {OEY }}(\mathrm{n})\end{array}$} \\
\hline & & Subcutis & Cesun & & \\
\hline $\mathrm{CaCo} 2$ & 1 & $0 / 5$ & $0 / 5$ & $b$ & $12.0 \pm 2.5(4)$ \\
\hline $\mathrm{CuCo} 2 \mathrm{EJ} 6$ & 4 & $5 / 5$ & $0 / 5$ & - & $15.9 \pm 3.1(7)^{*}$ \\
\hline $\mathrm{CaCo}_{2} \mathrm{CO}$ & 1 & $0 / 2$ & $\mathrm{ND}$ & $\mathrm{ND}$ & $23.9 \pm 7.5(3)^{* *}$ \\
\hline $\mathrm{CaCo} 2 \mathrm{NEOS}$ & 1 & $0 / 2$ & ND & $\mathrm{ND}$ & (2) \\
\hline SW480 & $\Downarrow$ & $5 / 5$ & $1 / 8$ & + & $13.7 \pm 4.9(9)$ \\
\hline $5 W 480 \mathbb{E} J$ & 5 & $2 / 2$ & $0 / 5$ & $\mathrm{ND}$ & $18.0 \pm 4.4(8)^{*}$ \\
\hline$S W 480 \mathbb{E} / 2$ & 4 & $2 / 2$ & $0 / 5$ & + & $13.5 \pm 3.0(8)$ \\
\hline SW480 E14 & 1 & $3 / 3$ & $0 / 5$ & $\mathrm{ND}$ & $13.2 \pm 3.7(9)$ \\
\hline SW480 EII7 & 1 & $2 / 2$ & $0 / 5$ & + & $14.7 \pm 5.1(8)$ \\
\hline SW480 COS & 30 & $2 / 2$ & $0 / 5$ & $\mathrm{ND}$ & $20.4 \pm 4.1(6)^{*}$ \\
\hline SW480 NEO3 & 1 & $2 / 2$ & $0 / 5$ & $\mathrm{ND}$ & $17.1 \pm 2.4(4)$ \\
\hline
\end{tabular}

a. Embryonic chick theart fragment assay; $b_{4}-=$ non-inwasive, $+=$ invasive, $N D=$ not done.

* Difference with the parental cell lines is statisticaliy significant as analyzed by Student's $t$ test $(0<0.05)$

**. Difference with the parentall cell lines is statistically significant as analyzed by Student's $t$ test $(p<0.005)$

\section{Protease production}

CaCo 2. U-PA secretion was increased in CaCo $2 \mathrm{EJ} 6$ cells in parallel with increased cHa-ras mRNA expression. The increase in u-PA secretion did not reach statistical significance. A similar trend was noted for u-PA in cell extracts, with values of $5 \%$ or less than recovered from the medium. The production of t-PA was not altered after transfection (Table 3).

Gelatinase activity was not observed in parental $\mathrm{CaCo} 2$ cells. It was induced in $\mathrm{CaCo} 2$ El6 and parallelled by an increased level of c-Ha-ras mRNA. Bands of gelatinase activity were visible at $107,97,81$ and $18 \mathrm{kDa}$ (Fig. 3 ).

$S W 480$. The production of U-PA, either secreted or cell bound, varied in SW480 transfected cell lines and did not correlate with the level of c-Ha-ras mRNA. The amount of $1-P A$ in the cell extracts of transfected and non-transfected cells was similar (Table 3).

Several bands with gelatinase activity were identified in parental SW480 cells, including one at $92 \mathrm{kDa}$. Consistent alterations in gelatinase activity were not observed in the SW480 transfected cell lines (not shown). 
Table 3. In vitro production of proteases and in vitro expression of cell allhesion molecules in parental and transfected cell lines.

\begin{tabular}{|c|c|c|c|c|c|c|c|c|}
\hline Cell line & $\begin{array}{l}\mathrm{w}-\mathrm{PA}^{\mathrm{a}} \\
\text { medium }\end{array}$ & $\begin{array}{l}\text { at-PA } \\
\text { cell }\end{array}$ & $\begin{array}{l}\mathrm{t}-\mathrm{PA}^{\mathrm{b}} \\
\text { cell }\end{array}$ & $\begin{array}{l}\text { Gelatinase } \\
\text { activity }\end{array}$ & E-cadheria & $\alpha_{2} \beta_{3}$ & $\begin{array}{l}\text { Integrin } \\
\alpha_{3} B_{1}\end{array}$ & $\alpha_{6} B_{1}$ \\
\hline $\mathrm{CaCo} 2$ & 1012 & 37 & 579 & - & ++4 & $=$ & $\mathbb{1}^{4}$ & $+4^{3}$ \\
\hline $\mathrm{CaCo}_{2} \mathrm{EJ} 6$ & 2177 & 130 & 600 & + & - & - & - & $t+x+4$ \\
\hline $\mathrm{CaCo} 2 \mathrm{COl}$ & 1744 & 51 & 835 & - & ++4 & - & \pm & - \\
\hline $\mathrm{CaCo} 2 \mathrm{NEO} 5$ & 586 & 36 & 497 & - & \pm & - & - & - \\
\hline SW 480 & 641 & 404 & 908 & \# & - & - & +4 & + \\
\hline SW480 EJI & 281 & 59 & 1057 & + & - & - & ++ & $+x+4$ \\
\hline $\mathrm{SW} 480 \mathrm{EJ} 2$ & 610 & 225 & 1062 & 4 & $\dot{2}$ & - & ++ & $+t$ \\
\hline SW480 EJ4 & 484 & 277 & 1099 & + & - & - & ++ & $+4+$ \\
\hline SW480 EJ17 & 900 & 33 & 1142 & + & - & - & $t+$ & +4 \\
\hline$S W 480 \mathrm{CO}$ & 1099 & 318 & 1019 & + & - & - & + & +1 \\
\hline SW $480 \mathrm{NEO} 3$ & 272 & 139 & 1061 & + & - & - & $t+$ & $+n+$ \\
\hline
\end{tabular}

a. Expressed in pg u-PA per $\mathrm{mg}$ protein cell extract, secreted into $1 \mathrm{ml}$ medium.

b. Expressed in pg u-PA/t-PA per mg protein cell extract.

c. $-=$ no gelatinase activity,$+=$ gelatinase activity.

d. Percentage positive cells: $-=0 \%, \pm=s_{3}+=1 \%-10 \%,+t=10 \%-75 \%,++t+=25 \%$.

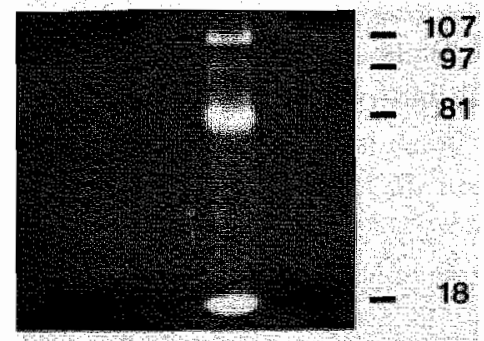

$123456 \quad 7$
Figure 3. Activity of gelatinases in $\mathrm{CaCo}_{2}$ and $\mathrm{CaCo}_{2}$ transfected cell lines.

Note the gelatinase activity bands at $107,97,81$ and $18 \mathrm{kDa}$ in $\mathrm{CaCo} 2 \mathrm{EJ} 6$. Lane 1: $\mathrm{CaCo} 2 \mathrm{NEO} 5 ; 2$ : $\mathrm{CaCo} 2 \mathrm{CO} 2$;

3: $\mathrm{CaCo} 2 \mathrm{CO} ;$ 4: $\mathrm{CaCo} 2 \mathrm{EJ} 12$; 5: $\mathrm{CaCo} 2 \mathrm{EJ} 6$;

6: $\mathrm{CaCo} 2 \mathrm{EI}$; 7: $\mathrm{CaCo} 2$.

\section{Cell adhesion molecules}

As cell adhesion molecules should be expressed at the surface of the cell in order to be functional, only membrane immunoreactivity of monoclonal antibodies specific for $\mathrm{E}$ cadherin or integrins was taken into account.

$\mathrm{CaCo} 2$. The parental $\mathrm{CaCo} 2$ cell line showed abundant membranous expression of $\mathrm{E}$ cadherin (Chapter 2), which was decreased in two transfected $\mathrm{CaCO} 2$ cell lines (Table 3). The decrease in E-cadherin expression was not associated with increased level of $\mathrm{c}$ Ha-ras mRNA. Membrane expression of $\alpha_{2} B_{1}$ integrin was not observed in $\mathrm{CaCo} 2$ cells or in transfected $\mathrm{CaCo} 2$ cells. The $\alpha_{3} B_{1}$ integrin was expressed at the membrane in less than $1 \%$ of the parental $\mathrm{CaCo} 2$ cells. c-Ha-ras oncogene transfected $\mathrm{CaCo} 2$ cells demonstrated a similar pattern of expression, in contrast to control transfected $\mathrm{CaCo} 2$ 
cells, where expression was not detected (Table 3). Expression of the $\alpha_{6} B_{1}$ integrin was demonstrated at the plasma membrane in $50 \%$ of the CaCo 2 cells, both parental and transfected (Table 3).

SW 480. Expression of E-cadherin was not detected in parental or transfected SW480 cells (Table 3). The $\alpha_{2} B_{1}$ integrin was not expressed at the plasma membrane in any of the SW 480 cell lines. About $20 \%$ of the parental SW480 cells expressed $\alpha_{3} B_{1}$ integrin at the membrane. A similar percentage of the cells was positive after transfection with the c-Ha-ras oncogene and after control transfections of SW480 cells. Membrane expression of $\alpha_{6} B_{3}$ integrin was observed in $10 \%$ of the parental $\mathrm{SW} 480$ cells (Table 3 ). Increased expression of $\alpha_{6} \beta_{1}$ integrin was observed in several transfected SW480 cell lines, not related with an increased level of c-Ha-ras mRNA after transfection with the c-Ha-ras oncogene.

\section{Markers of differentiation}

$\mathrm{CaCo}$ 2. Expression of sucrase-isomaltase was observed in the brushborders of $\mathrm{CaCo} 2$ cells (Fig. 4) and varied considerably after transfection (Table 4) without any relation to c-Ha-ras mRNA level. Mucin production was readily detected in the cytoplasm of parental $\mathrm{CaCo} 2$ cells and to a similar degree after transfection (Fig. 4, Table 4). Chromogranine A was expressed in none of the $\mathrm{CaCo} 2$ cell lines.

$S W 480$. Cytoplasmic mucin production was observed in about $1 \%$ of the parental SW480 cells. The percentage of cells with cytoplasmic immunoreactivity increased to $10 \%$ in two transfected SW480 cell lines, but the increase was not associated with the level of c-Ha-ras mRNA (not shown). Sucrase-isomaltase and chromogranine A were neither detected in parental nor in transfected SW480 cell lines.
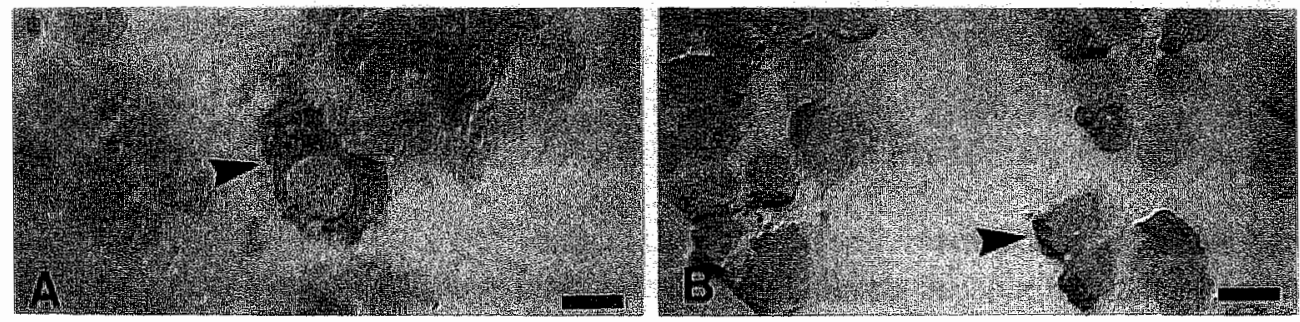

Figure 4. Immunohistochemistry of cell lines in vitro.

A. Muciun production demonstrated in $\mathrm{CaCo} 2$ El6. Note the strong cytoplasmic reactivity. B. Expression of sucrase-isomaltase in CaCo 2. Note the highly pollarized staining at one side of the cell. Arrows indicate cells to be held up as an example for cells with immunoreactivity for the monoclonal antibody used. Bar is $5 \mu \mathrm{m}$. 
Table 4. Expression of differentiation markers in $\mathrm{CaCa} 2$ and $\mathrm{CaCo}_{2}$ transfected cell lines:

\begin{tabular}{llll}
\hline Cell line & $\begin{array}{l}\text { Sucrase } \\
\text { isomaltase }\end{array}$ & Mucin & Chronogranine A \\
\hline $\mathrm{CaCl} 2$ & $++^{\mathrm{a}}$ & $+^{\mathrm{a}}$ & - \\
$\mathrm{CaCo} 2 \mathrm{EJ} 6$ & - & + & - \\
$\mathrm{CaCo} 2 \mathrm{CO}$ & +++ & + & - \\
$\mathrm{CaCo} 2 \mathrm{NEO} 5$ & - & \pm & - \\
\hline
\end{tabular}

a. Percentage positive cells: $-=0 \%, \pm=\leq,+=1 \%-10 \%$, $++=10 \%-75 \%,++=\geq 75 \%$.

\subsection{DISCUSSION}

In this study we analyzed in c-Ha-ras oncogene transfected $\mathrm{CaCo} 2$ and SW480 cells a broad spectrum of phenotypic characteristics. The effects of c-Ha-ras oncogene transfection can be grouped in two different categories. Firstly, phenotypic alterations such as the in vitro morphology of SW480 transfected cell lines, were found without any relation to increased c-Ha-ras mRNA levels, we therefore assume that these alterations are brought about by the transfection procedure. Also clonal variation might account for these alterations, as has been reported for the expression of sucrase isomaltase in $\mathrm{CaCo} 2$ cells (52). The observed variation in sucrase isomaltase expression in the transfected $\mathrm{CaCo} 2$ cell lines is also explained most likely by clonal variation. An explanation for such an effect of transfection could be insertional gene(in)activation.

The second category of phenotypic alterations are those coinciding with increased c-Haras mRNA levels, which therefore, presumably result from the introduction and transcription of the c-Ha-ras oncogene. These alterations were found in $\mathrm{CaCo} 2$ cells only and include induction of tumorigenicity of carcinoma cells injected in the subcutis and induction of gelatinase activity. Whether there is a functional relationship between tumorigenicity and gelatinase activity remains to be determined. The induction of tumorigenic potential was not accompanied by loss of differentiation. This corresponds with findings in Ha-ras transformed rat hepatocytes, which became tumorigenic and retained the ability to express liver specific genes $(53,54)$. Clonal variation cannot be excluded as a cause of the occurrence of tumorigenicity and increased gelatinase activity in transfected $\mathrm{CaCo} 2$ cells. However, others also observed tumorigenicity after transfection of non-tumorigenic $\mathrm{CaCo} 2$ cells with the c-Ha-ras oncogene (55), which makes clonal variation a less likely explanation.

Bearing in mind that tumor cells transfected with the c-Ha-ras oncogene frequently demonstrate a reduced requirement of growth factors in vitro $(6,56-61)$ it is conceivable that induction of tumorigenicity in vivo in c-Ha-ras oncogene transfected $\mathrm{CaCo} 2$ cells might be caused also by a reduced requirement of growth factors. This 
confers growth autonomy to tumor cells, and allows them to escape regulation by the microenvironment $(62,63)$. Growth autonomy can occur through two mechanisms. Firstly, the c-Ha-ras oncogene has been shown to induce expression of growth factors $(57,59,60)$ and growth factor receptors $(64)$. An autocrine loop is established when the induced growth factors can bind to endogenously expressed growth factor receptors. Secondly, normal cells increase the level of the active GTP.p2l ras complex after activation of the receptor for insulin, PDGF, or EGF (65-67). Which mechanism is effective remains to be established.

Contrary to what we expected in our experiments none of the $\mathrm{CaCo} 2$ cells and none of the transfected SW480 cells developed primary tumors after orthotopic injection. Observations concerning the influence of the c-Ha-ras oncogene on orthotopic in vivo behavior could therefore not be made. However, the c-Ha-ras oncogene neither alters in vitro invasive capacities nor induces invasive capacity in CaCo 2 and SW480 cells in the subcutis. These observations could be taken as circumstantial evidence suggesting that the c-Hatras oncogene is not involved in the acquisition of invasive potential of human colorectal carcinoma cells.

In summary, our results suggest that; (1) The c-Ha-ras oncogene induces tumorigenic potential to non-tumorigenic $\mathrm{CaCo} 2$ cells along with induction of gelatinase activity; (2) Neither in CaCo 2 cells nor in SW480 cells introduction of the c-Ha-ras oncogene confers invasive ability. These data are in keeping with an early position of the ras gene mutations in models of colorectal carcinogenesis. 


\subsection{REFERENCES}

1. Cooper GM, ed: Oncogenes. first ed. Boston: Jones and Bartlet Publishers, 1990

2. Parada LF, Tabin CJ, Shih C, Weinberg RA: Human EJ bladder carcinoma oncogene is homologue of Harvey sarcoma virus ras gene. Nature. 1982;297: 474-478.

3. Goldfarb $\mathrm{M}$, Shimizu $\mathrm{K}$, Perucho $\mathrm{M}$, Wigler $\mathrm{M}$ : Isolation and preliningry characterization of a human transfforming gene from T24 bladder carcinoma cells. Nature. 1982; 296: 404-409.

4. Pulciani $S$, Santos $\mathrm{E}$, Lauver $\mathrm{AV}$, Long $\mathrm{LK}$, Robbins $\mathrm{KC}$, Barbacid $\mathrm{M}$ : Oncogenes in human tumor cell lines: molecular cloning of a transforming gene from human bladder carcinoma cells. Proc. Natl. Acad. Sci. USA 1982; 79: 2845-2849.

5. Fearon ER, Vogelstein B: A genetic model for colorectal tumorigenesis. Cell. 1990; 61: 759-767.

6. Hurlin PJ, Maher VM, McCormick JJ: Malignant transformation of human fibrobllasts caused by expression of a transfected T24 HRAS oncogene. Proc. Natl. Acad. Sci. U. S. A. $1989 ; 86: 187.191$.

7. Wilson DM, Yang DJ, Dillberger JE, Dietrich SE, Maher VM, McCormick JI: Malignant transformation of human fibroblasts by a transfected N-ras oncogene. Cancer. Res. 1990; 50: $5587-5593$.

8. Fry DG, Milam LD, Dillberger JE, Maher VM, McCormick JJ: Malignant transformation of an infinite life span human fibroblast cell strain by transfection with v-Ki-ras. Oncogene. $1990 ; 5: 1415.1418$.

9. Mizuno $T$, Kaibuchi $K$, Yamanoto $T$, et al: A stimulatory GDP/GTP exchange protein for smg $\mathrm{p} 21$ is active on the post-translationally processed form of c-Ki-ras p21 and rhoA p21. Proc. Natl. Acad. Sci. USA 1991; 88: 6442-6446.

10. Bourne HR, Sanders DA, McCormick F: The GTPase superfamily: conserved structure and molecular mechanism. Nature. 1991; 349:117-127.

11. de Vries JE, Kornips FHAC, Marx P, Bosman FT, Geraedts JPM, ten Kate J: Transfected c-Ha-ras oncogene enhances karyotypic instability and integrates predominantly in aberrant chromosomes. Cancer. Genet. Cytogenet. 1993; 65: 35-43.

12. Spandidos DA, Wilkie NM: Malignant transformation of early passage rodent cells by a single mutated human oncogere. Nature. 1984; $310 ; 469-475$.

13. Vogelstein B, Fearon ER, Hamiton $\mathrm{SR}$, et al: Genetic alterations during colorectal-tumor development. N Engl. J. Med. 1988; 319:525-532.

14. Bos JL: Ras oncogenes in human cancer: A review. Cancer. Res. 1989; 49:4682-4689.

15. Bagli DJ, D'Emilia JC, Summerhayes $1 \mathrm{C}$, Steele GD, Barlozzari T: c-Ha-ras-I oncogene-induced differentiation and natural killer cell resistance in a human colorectall carcinoma cell line. Cancer. Res. 1990; 50: 2518-2523.

16. Cellano P. Berchtold CM. Mabry $M$, et al: Induction of markers of normal differentiation in human colon carcinoma cells by the v-ras oncogene. Cell Growth and Differentiation 1993; 4: $341-347$.

17. Testa JE, Medcalf RL. Cajot JF, Schleuning WD, Sordat B: Urokimase-type plasminogen activator biosynthesis is induced by the FJ-Ha-ras oncogene in CL26 mouse colon carcinoma cells. Int. J, Cancer. 1989; 43: 816-822.

18. Dano K, Andreasen PA, Grondahl-Hansen J, Kristensen P, Nielsen L.S Skriver L: Plasminogen activators, tissue degradation, and cancer. Adw. Cancer. Res. 1985; 44: 139.266. 
19. Axefrod $J H$, Reich $R$, Miskin $R$ : Expression of human recombinant plasminogen activators en hances invasion and experinental netastasis of H-rasi-transformed NTH 3 T3 cells. Mol. Cell. Biol. 1989; 9:2133-2141.

20. Quax PHA yan Muijen GNP, Weening-Verhoeff EJD, et al: Metastatic behavior of human melanoma cell limes in nude mice correlates with urokinase-type plasminiogen activator, its type-1 inhibitor, and urokinase mediated matrix degradation. J. Cell. Biol. 1991; 115: $191-199$.

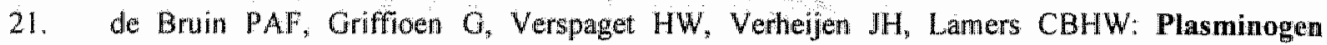
activators and tumor development in the human colon: activity levels in normall mucosa, adenomatous polyps, and adenocarcinomas. Cancer. Res. 1987; 47: 4654-4657.

22. Sier $C P M$, Verspaget $H W$, Griffioen $G_{1}$ et $a l$. Imbalance of plasminogen activators and their inhibitors in human colorectal neoplasia. Gastroenterology 1991; 101: 1522-1.528.

23. Liotta $L A_{\text {. }}$ Steeg PS, Stetler-Stevenson WG: Cancer metastasis and angiogenesis: an limbalance of positive and negative regulation. Cell. 1991; 64: 327-336.

24. Capon DJ, Chen EY, Levinson $\mathrm{AD}$, Seeburg PH, Goeddel DV: Complete nucleotide sequences of the T24 human bladder carcinoma oncogene and its normal homologue. Nature. 1983; 302: 33-37.

25. Fogh $J$, Fogh $\mathrm{M}$, Orfeo $\mathrm{T}$ : One hundred and twenty-seven cultured human tumor cell lines producing tumors in nude mice. J. Nati. Cancer. Inst. 1977, 59: 221-225.

26. Pinto $M$, Robine-Leon $S$, Appay M-D, et al: Enterocyte-like differentiation and pollarization of the human colon carcinoma cell line $\mathrm{CaCo-2}$ in culture. Biol. Cell. 1983; 47:323-330.

27. Chantret 1 , Barbat $A_{i}$ Dussaulx E, Brattain $M G$, Zweibaun $A$ : Epithelial polarity, villin expression, and enterocytic differentiation of cultured human colon carcinoma cells: a survey of twenty cell lines. Cancer. Res. 1988; 48: 1936-1942.

28. de Vries JE, Dinjens WNM, Verspaget HW, et al: Behavior of orthotopic human colorectal carcinoma xenografts in relation to in vitro invasion. $1001993 ; 100: 100$.

29. Leibovitz A, Stinson JC, McCombs WB, et al: Classification of human colorectal adenocarcinoma cell lines. Cancer Research 1976; 36: 4562-4569.

30. Quaroni A: Identification and biogenesis of intestinal cell-surface components. Progress in Cancer Research and Therapy 1984; 29: 267-293.

31. Bernhard EJ, Muschel RJ, Hughes $\mathrm{EN}$ : Mr 92,000 gelatinase release correlates with the metastatic phenotype in transformed rat embryo cells. Cancer. Res. 1990; 50: 3872-3877.

32. Stacey DW, Kung H-F: Transformation of NIH 3T3 cells by microinjection of Ha-ras p21 protein. Nature. 1984; 310 : 508-511.

33. Farmisco JR, Gross $M$, Kamata T, Rosenberg $M$, Sweet $R W$ : Microinjection of the oncogene form of the human H-ras $(\mathrm{T}-24)$ protein results in rapid proliferation of quiescent cells. Cell. 1984; 38: 109-117.

34. Southern $\mathrm{PJ}$, Berg P: Transformation of mammalian cells to antibiotic resistance with a bacteriall gene under control of the $\mathbf{S V 4 0}$ early region promoter. $1 . \mathrm{Mol}$. Appl. Genet. 1982, 1: $327-341$.

35. Sambrook J, Fritsch EF, Maniatis T: Molecular cloning. second ed. New York: Cold Spring Harbor Laboratory Press, 1989

36. Graham FL, van der $\mathrm{Eb} \mathrm{AJ}$ : A new technique for the assay of infectivity of human adenovirus 5 DNA. Virology 1973; $52: 45.6-467$.

37. Chen $\mathrm{C}$, Okayama $\mathrm{H}$ : High-efficiency transformation of mammalian cells by plasmid DNA. Mol. Cell. Biol. 1987; 7: 2745-2752. 
38. Schutte B, Reynders MM, wan-Assche CL, Hupperets PS, Bosman FT. Blijhan GH: An improved method for the immunocytochemical detection of bromodleoryu ridine labeled nuclei using flow cytometry. Cytometry. 1987; $8: 372-376$.

39. White RA, Terry NH, Meistrich ML: New methods for calculating kinetic properties of cells in vitro using pulse labelling with bromodeoxyuridine. Cell. Tissue. Kinet. 1990; 23 ; $561-573$.

40. Binnema DJ, van lersel JJL, Dooljewaard $\mathrm{G}$ : Quantitation of urokinase antigen in plasma and culture media by use of an ELISA. Thromb. Res. $1986 ; 43 ; 569.577$.

41. Rijken DC, van Hinsbergh VWM, Sens EHC: Quantitation of tissue-type plasminogen activator in human endothelial cell cultures by use of an enzyme immunoassay. "Thromb. Res. 1984; 33: 145-153.

42. Lowry OH, Rosebrough NJ, Farr AL, Randall RJ: Protein measurement with the Folin phenol reagent. J. Biol. Chem. 1951; 193: 265-275.

43. Zucker S, Wieman J, Lysik RM, ot al: Gelatin-degrading type IV collagenase isolated from human small cell lung cancer. Invasion. Metastasis. 1989; 9:167-181.

44. Behrens J, Birchmeier W, Goodmun SL, Imhof BA: Dissociation of Madin-Darby canine kidney epithelial cells by the monoclonal antibody anti-are-1: mechanistic aspects and identification of the antigen as a component related to uvomorulin. 1 . Cell. Biol. 1985; 101: 1307-1315.

45. Giltay JC, Brinkman HJ, Modderman PW, von-dem-Borne AE, van-Mourik JA: Human vascular endothelial cells express a membrane protein complex immumochemically indistinguishable from the plateler VLA-2 (glycoprotein Ia-IIa) complex. Blood. 1989; 73: $1235-1241$.

46. Fradet $\mathrm{Y}$, Cordon-Cardo $\mathrm{C}$, Thomson $\mathrm{T}$, ef al: Cell surface antigens of lnuman bladder cancer defined by mouse monoclonal antibodies. Proc. Natl. Acad. Sci. U. S. A. 1984; 81: 224-228.

47. Sonnenberg $A$, Hogervorst $F$, Osterop $A$, Veltman FE: Identification and characterization of a novel antigen complex on mouse mammary tumor cells using a monoclonal antibody against platelet glycoprotein Ic. J. Biol. Chem. 1988; 263: 14030-14038.

48. Zwëbaum A, Hauri HP, Sterchi E, Haffen $K$, Bamat J, Sordat $B$ : Immunohistological evidence, obtained with monoclonal antibodies, of small intestinal brush border hydrolases in human colon cancers and foetal colons. Int. J. Cancer. 1984; 34: 591-598.

49. Verstijnen CPHJ, Arends JW, Moerkerk PTM, Pijls M, Kuypers-Engelen B, Bosman FT: Collonic epithelium reactive monoclonal antibodies. Idenfification and immunohistochemical localization of the target epitopes. Histochemistry. 1989; 92: 397.406.

50. Lloyd RV, Wilson BS: Specific endocrine tissue marker defined by a monoclonal antibody. Science. $1983 ; 222: 628-630$

51. de Bruine AP, de Vries JE, Dinjens WNM, et al: Human CaCo 2 cells transfected with c-Ha-ras as a model for endocrine differentiation in the large intestine. Differentiation. $1993 ; 53: 51-60$.

52. Beaulieu J-F, Quaroni $A$ : Clonal analysis of sucrase-isomaltase expression in the human colon adenocarcinoma CaCo-2 cells. Biochem. J, $1991 ; 280: 599-608$.

53. Fang $X J$, Flowers $M$, Keating $A$, Cameron $R$, Sherman $M$; ras transformation of simian wirus 40-immortalized rat hepatocytes: an in vitro model of hepatocarcinogenesis. Cancer. Res. 1992; $52: 173-180$.

54. Isom $\mathrm{HC}$, Woodworth $\mathrm{CD}$, Meng $\mathrm{Y}$, Kreider J, Miller $T$, Mengel $L$; Introduction of the ras oncogene transforms a simian virus 40 -immortalized hepatocyte cell lime without loss of expression of albumin and other liver-specific genes. Cancer. Res. 1992; $52: 940-948$. 
55. Delage $\$$, Chastre $E$, Empereur $S$, et al: Increased protein kinase $C$ allpha expression in human colonic $\mathrm{CaCo} 2$ cells after insertion of human Ha-ras or polyoma virus middle $\mathrm{T}$ oncogene. Cancer. Res. 1993; 53:2762-2770.

56. Yoakum GH, Lechner JF, Gabrielson EW, ef al: Transformation of human bronchial epithelial cells transfected by Harvey ras oncogene. Science: $1985 ; 227: 1174-1179$.

57. Andrejauskas $\mathrm{E}$, Moroni $\mathrm{C}$ : Reversible abrogation of IL-3 dependence by an inducible $\mathrm{H}$-ras oncogene. Embo. J. 1989; 8: 2575-2581.

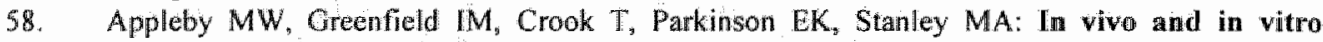
effects of $\mathrm{v}$-fos and EJ-Ha-ras oncogene expression in murine epidermal keratinocytes. Oncogene. 1989:4:1323-1330.

59. Ciardiello $\mathrm{F}, \mathrm{McGead}$. $M L_{*} \mathrm{Kim} N$, et al: Transforming growth factor-alpha expression is enhanced in liuman mammary epitheliall cells transformed by an activated c-Ha-ras protooncogene but not by the c-neu protooncogene, and overexpression of the transforming growth factor-alpha complementary DNA leads to transformation. Cell. Growth. Differ. 1990; 1:407-420.

60. Demetri GD, Ernst TJ, Pratt ES 2d, Zenzie BW, Rheinwald JG, Griffin JD: Expression of ras oncogenes in cultured human cells alters the transcriptional and posttranseriptional regulation of cytokime genes. J. Clin. Invest. $1990 ; 86: 1261-1269$.

61. Kinsella AR, Fiszer-Maliszewska L, Mitchell EL, Guo YP, Fox M, Scot D: Introduction of the activated $\mathrm{N}$-ras oncogene into human fibrobllasts by retroviral vector induces morphological transformation and tumorigenicity. Carcinogenesis. 1990; 11: 1803-1809.

62. Chadwick DE, Lagarde AE: Coincidental aequisition of growth autonomy and metastatic potential during the malugnant transformation of factor-dependent CCL39 lung fibroblasts. J. Natl. Cancer. Inst. 1988; 80:318-325.

63. Liotta LA: Growth autonomy: The only requirement for metastasis? J. Natl. Cancer. Inst. 1988; 86: 18.

64. Theodorescu D, Cornil I, Sheehan C, Man MS, Kerbel RS: Ha-ras induction of the invasive phenotype results in up-regulation of epidermal growth factor receptors and altered responsiveness to epidermal growth factor in human papillary transitional cell carcinoma cells. Cancer. Res. 1991; 51: 4486-4491.

65. Burgering BMT, Medema RH, Maassen JA, et al: Insulin stimulation of gene expression mediated by p21 ras activation. The EMBO Journal 1991;10:1103-1109.

66. Satol $T$, Endo $M$, Nakafuku $M$, Nakanura $S$, Kaziro $Y$ : Platelet-derived growth factor stimulates formation of active p21ras.GTP complex in Swiss mouse 3T3 cells. Proc. Natl. Acad. Sci. U. S. A. 1990; $87: 5993-5997$.

67. Satoh T, Endo M, Nakafuku M, Akiyama $T$, Yamamoto T, Kaziro $Y$ : Accumulation of p21ras.GTP in response to stimulation with epidernal growth factor and oncogene products with tyrosine kinase activity. Proc. Natl. Acad. Sci. U. S. A. 1990; 87: 7926-7929. 


\title{
CHAPTER 6
}

\author{
HUMAN CACO 2 CELLS \\ TRANSFECTED WITH C-HA-RAS \\ AS A MODEL FOR ENDOCRINE DIFFERENTIATION \\ IN THE LARGE INTESTINE
}

A.P. de Bruine, J.E. de Wries, W.N.M. Dinjens, P.M. Moerkerk, E.P.M. van der Linden, M. Pujls,

J. ten Kate, and F.T. Bosman.

Differentiation 1993; $53: 51-60$.

(Reprinted with permission) 


\subsection{INTRODUCTION}

In the colorectum, endocrine neoplasms in their most characteristic form are encountered as classical carcinoid tumors (1). However, endocrine differentiation in large intestinal epithelial tumors has been recognized to occur in a much wider spectrum of tumors, comprising poorly differentiated small cell undifferentiated carcinomas $(2,3)$ and mixed exocrine/endocrine carcinomas with variable numbers of endocrine tumor cells (4). In colorectal adenocarcinomas, endocrine differentiation can be found in approximately $30 \%$ of cases (5). This relatively high frequency and the fact that some reports state a poorer prognosis for colon carcinornas with endocrine cells $(6,7)$ is indicative for the potential importance of this phenomenon. The more aggressive behavior could be related to growth stimulatory effects of peptides and/or amines produced by endocrine tumorcells (8), which may act as autocrine or paracrine growth factors (9).

To study the biological relevance of endocrine differentiation in colorectal adenocarcinomas, well defined tumor models are of utmost importance. This has been hampered by the relative scarcity of colorectal adenocarcinoma cell lines with endocrine features. So far, only two colorectal cancer cell lines with endocrine differentiation have been well documented: HRA-19 (10) and NCI-H716 (11). In HRA-19 endocrine differentiation exclusively occurs in tumor xenografts, which are morphologically well differentiated adenocarcinomas. This finding suggests that stromal factors are involved in the induction of endocrine differentiation (12). NCI-H716 xenografts are morphologically poorly differentiated adenocarcinomas, not fully representative of the predominant type of colorectal adenocarcinoma. Endocrine differentiation is observed extensively in NCL-H716 xenografts, but can also be induced in vitro by specific extracellular matrix components (13). The availability of more cell lines, morphologically corresponding with the predominant (well differentiated) type of colorectal carcinoma and harboring all colorectal epithelial cell lineages, would be useful in order to elucidate the mechanism regulating endocrine differentiation.

In view of their high level of differentiation (14), we chose to investigate Caco-2 cells for endocrine characteristics. Initial experiments demonstrated that under standard conditions of xenografting a low take rate is attained. We therefore transfected these cells with a point mutated c-Harvey (Ha)-Ras-gene, as Ras overexpression has been associated with tumor progression (15), metastatic capacity $(16,17)$, and endocrine differentiation $(18,19)$. The present report describes the c-Ha-Ras transfection of Caco2 , the properties of the obtained cell lines and their use as a model to study endocrine differentiation in colorectal cancer. 


\subsection{MATERIALS AND METHODS}

\subsubsection{Tumor cells}

Caco-2 cells were purchased from the American Type Culture Collection (ATCC, Rockville, Maryland, USA). Caco-2 EJ6 cells were established from this native cell line by transfection.

\subsubsection{Transfection experiments}

The plasmid $\mathrm{pSV}_{2}$ neo, containing the neomycin gene $(20)$, the plasmid $\mathrm{pSV}_{3}$ neoEJ, containing a $6.6 \mathrm{~kb}$ genomic Bam HI fragment of the c-Ha-Ras oncogene with a $\mathrm{G}$ to $\mathrm{T}$

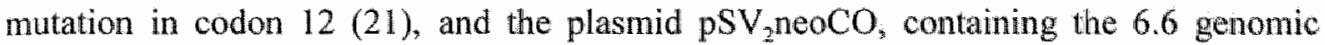
Bam HI fragment of the c-Ha-Ras proto oncogene (22), were a kind gift of Prof.Dr. Cerutti (Swiss Institute for Experimental Cancer Research, CH-1066 Epalinges, Switzerland). Plasmids were isolated by the alkaline lysis method (23) and further purified by precipitation with $7.5 \mathrm{M}$ ammoniumacetate $\left(\mathrm{NH}_{4} \mathrm{Ac}\right)$.

For transfection, $5 \mu \mathrm{g}$ of plasmid DNA was coprecipitated with calciumphosphate according to the protocol of Graham and van der Eb (24), with the modifications described by Chen and Okayama (25). The addition of the plasmid/calciumchloride mixture to $N_{0} N$-bis(2-hydroxyethyl)-2-aminoethane-sulfonic acid buffered saline was carried out in continuous airflow. It was added to $2 \times 10^{5}$ exponential growing $\mathrm{Caco}-2$ cells in a $75 \mathrm{~cm}^{2}$ culture flask with $10 \mathrm{ml}$ medium. After two days, the cells were trypsinized and plated into 96-well plates, where selection was started by adding 800 $\mu \mathrm{g} / \mathrm{ml}$ of gentamycin (G418, GIBCO, Paisley, Scotland) to the culture medium. After three weeks, selection was completed. Only wells containing one colony were used for further experiments. In the present study, the clones Caco-2 EJ6 (containing $\mathrm{pSV}_{2}$ neoEJ), Caco-2 $\mathrm{CO} 1$ and $\mathrm{Caco}-2 \mathrm{CO} 2$ (containing $\mathrm{pSV}_{2}$ neoCO), and $\mathrm{Caco}-2 \mathrm{D} 5$ Neo (containing $\mathrm{pSV}_{2}$ neo), were used (Table 1).

\subsubsection{Southern blot analysis}

After lysis of cells with $1 \%(\mathrm{v} / \mathrm{v})$ proteinase $\mathrm{K}(10 \mathrm{mg} / \mathrm{ml})$ and $0.5 \%$ sodiumdodecylsulfate (SDS) (1 hr., $\left.56^{\circ} \mathrm{C}\right)$, DNA was extracted with a mixture of phenol, chloroform and isoamylalcohol $(25: 24: 1 \mathrm{v} / \mathrm{v})$, followed by chloroform and isoamylalcohol $(24: 1 \mathrm{v} / \mathrm{v})$, and precipitated with isopropanol and $0.1 \mathrm{M}$ sodiumacetate (NaAc). The pellet was washed with $70 \%$ ethanol, suspended in TE buffer $(10 \mathrm{mM}$ Tris $\mathrm{pH} 7.4,0.1 \mathrm{mM}$ ethylenediaminetetraacetic acid (EDTA)) and stored at $4^{\circ} \mathrm{C}$.

Bam HI digested DNA was size-fractionated by overnight electrophoresis at $23 \mathrm{~V}$ in $0.7 \%$ agarose gel in TAE buffer $(0.04 \mathrm{M}$ Tris-acetate, $0.001 \mathrm{M}$ EDTA) and transferred to Hybond $\mathrm{N}+$ filters by overnight blotting (RT). Filters were neutralized (30 $\mathrm{sec}$, in $2 \times \mathrm{SSC}_{,} 0.5 \mathrm{M}$ Tris-HCl, $\mathrm{pH} 7.4$ ) and dried at $\mathrm{RT}$.

Filters were prehybridized (overnight, $42^{\circ} \mathrm{C}$ ) in $40 \%$ formamide, I M sodiumchloride $(\mathrm{NaCl}), 0.05 \mathrm{M}$ sodiumphosphate, $1 \% \mathrm{SDS}, 10 \%$ dextransulphate and $0.1 \mathrm{mg} / \mathrm{ml}$ denatured salmon sperm DNA. A $3 \mathrm{~kb}$ Sac I fragment containing the four coding 
regions of the c-Ha-Ras gene was radiolabeled with ${ }^{32} \mathrm{P}$ by the random primer method $(26,27)$, and added to the hybridization mixture. Hybridization took place overnight at $42^{\circ} \mathrm{C}$. Washing steps were $2 \times S S C\left(2 \times 5^{\circ}\right.$, RT $), 0.1 \times S S C$ and $1 \%$ SDS $\left(2 \times 15^{\prime}, 60^{\circ} \mathrm{C}\right)$ and $2 \times S S C\left(2 \times 15^{\circ}\right.$, RT). The filters were exposed to Kodak-XAR film, at $-70^{\circ} \mathrm{C}$ with an Ilford intensifying screen:

\subsubsection{Northern blot analysis}

RNA was extracted with the cesiumchloride gradient method after lysing cells in a $4 \mathrm{M}$ guanidinium thiocyanate solution, and precipitated with $96 \%$ ethanol/30 $\mathrm{mM} \mathrm{NaAc}$. RNA was size-fractionated by electrophoresis ( 3 hrs., RT) at $100 \mathrm{~V}$ in $1 \%$ agarose $/ 6 \%$ formaldelayde gel and transferred to Hybond $\mathrm{N}+$ fillters by overnight blotting.

Ras mRNA expression was detected using the same probe as in Southern blot analysis. Parallel hybridization for $B$ actin mRNA was performed as an internal standard for the total amount of RNA, with a $1.3 \mathrm{~kb}$ cDNA probe (courtesy of Dr. T. Berkvens, University of Leiden). The Northern blots were prehybridized overnight at $42^{\circ} \mathrm{C}$ in $50 \%$ formamide, $1 \% \mathrm{SDS}, 1 \mathrm{M} \mathrm{NaCl}, 10 \%$ dextran sulphate and $0.1 \mathrm{mg} / \mathrm{ml}$ denatured salmom sperm DNA. For hybridization, denatured Ras and $B$ actin probes, radiolabeled with ${ }^{32} \mathrm{P}$ by the random primer method, were added to the hybridization mixture. After overnight incubation $\left(42^{\circ} \mathrm{C}\right)$, the filters were washed in $2 \times S S C\left(2 \times 5^{\circ}, \mathrm{RT}\right), 2 \times S S C$ and $1 \%$ SDS $\left(2 \times 15^{\prime}, 60^{\circ} \mathrm{C}\right)$ and $0.1 \mathrm{SSC}\left(2 \times 15^{\circ}, \mathrm{RT}\right)$. Exposure of the filters was as described.

\subsubsection{Cell culture}

Cells were cultured at $37^{\circ} \mathrm{C}$ in a humified atmosphere with $5 \% \mathrm{CO}_{2}$. The medium consisted of Dulbecco's modified Eagles" minimal essential medium (DMEM, Flow Laboratories, Zwanenburg, The Netherlands), supplemented with $10 \%$ fetal bovine serum (FBS, Boehringer, Mannheim, FRG). Caco-2 EJ6 cells were maintained in selective medium containing $800 \mu \mathrm{g} / \mathrm{ml}$ gentamycin.

Induction of endocrine differentiation in Caco-2 cells was attempted by supplementing the medium with glucose (final concentration $25 \mathrm{mM}$ ), sodium butyrate (NaBT, $2 \mathrm{mM}$ ), dimethylsulfoxide (DMSO, $2 \% \mathrm{v} / \mathrm{v}$ ), or retinoic acid (RA, $35 \mu \mathrm{M}$ ). Cells were also cultured in serum free medium and in glucose free medium supplemented with $2.5 \mathrm{mM}$ inosine. (DMSO was obtained from Merck, Darmstadt, FRG; all other chemicals from Sigma, St. Louis, USA).

Furthermore, both Caco-2 and Caco-2 EJ6 cells were cultured in serumfree, defined medium (DMEM with $50 \mathrm{nM}$ hydrocortisone, $5 \mu \mathrm{g} / \mathrm{ml}$ insullin, $5 \mu \mathrm{g} / \mathrm{ml}$ transferrin, 5 $\mathrm{nM}$ sodiumselenite, $100 \mu \mathrm{M}$ ethanolamine, $1 \mu \mathrm{M}$ putrescine, $4 \mu \mathrm{M}$ spermidine, $4 \mu \mathrm{M}$ spermine and $0.1 \%$ bovine serum albumin (BSA)) in the presence or absence of basic fibroblast growth factor ( $\mathrm{bFGF}, 10 \mathrm{ng} / \mathrm{ml}$ ) and transforming growth factor $\mathrm{B}$ (TGFB, 1 $\mathrm{ng} / \mathrm{ml}$ ). Several modifications of the culturing substrate were tested for their capacity to induce endocrine differentiation. Cells were cultured on amnion membranes, prepared as described previously (28), on feeder layers of two types of human fibroblasts (adult fibroblasts, explanted from dermis of human skin obtained at autopsy, and embryonal 
fibroblasts, purchased from the ATCC), and in two types of artificial extracellular matrix gels. Vitrogen 100 was purchased from the Collagen Corporation (Palo Alto, CA., USA), and basement membrane Matrigel from Collaborative Research incorporated (Bedford, Mass., USA).

\subsubsection{In vivo studies}

For the xenografting experiments, immunedeficient female $\mathrm{CD}$ nu/nu mice (Charles River Wiga, Sulzfeld, FRG) aged 3-5 weeks, were inoculated subcutaneously (s.c.) with suspensions of $3-5 \times 10^{6}$ single tumor cells in phosphate buffered saline (PBS), obtained by gentle trypsinization ( $0.25 \%$ trypsine, DIFCO, Detroit, Mich., USA) at $37^{\circ} \mathrm{C}$.

To enhance the take rate, s.c. injection of single tumor cell suspensions in soluble Vitrogen 100 , or s.c. implantation of Vitrogen 100 gels containing $0.5 \times 10^{6}$ tumor cells cultured for 5 days (12) were attempted. Furthermore, animals were injected intraperitoneally every fifth day with $0.5 \mathrm{mg}$ of polyclonal antibody against asialo GMI ( $\propto$ ASGM1, Wako Chemicals GmbH, Neuss, FRG), to eliminate natural killer (NK) cell activity (Table 2 ).

\subsubsection{Cell and tissue processing}

Cells were harvested by gentle scraping. After washing twice in icecold PBS, cells were immersed $\left(3 \mathrm{hrs} ., 4^{\circ} \mathrm{C}\right)$ in fixative containing ethanol $(100 \%)$, formalin $(36 \%)$ and glacial acetic acid $(97 \%)(15: 14: 1 \mathrm{v} / \mathrm{v})$ or in ethanol $70 \%$. Cells were resuspended in $4 \%$ agarose gel prior to routine tissue processing and paraffin embedding. Cells grown in Vitrogen 100 or basement membrane Matrigel and nude mouse xenogratts were fixed and processed similarly. Xenografts were additionally snap frozen in liquid isopentane cooled to $-70^{\circ} \mathrm{C}$.

\subsubsection{Histochemistry and immunohistochemistry}

Paraffin sections $(4 \mu \mathrm{m})$ were screened for endocrine differentiation by combined histochemical staining for argyrophilia (Grimelius technique) and immunohistochemical staining with a monoclonal antibody against human chromogranin A (LK2H110, Hybritech, San Diego, CA., USA). For the latter, a standard indirect peroxidase labeled antibody technique was applied as was previously reported (29).

Phenotypical characterization of xenografts of Caco-2 and Caco-2 EJ6 was designed to identify the various intestinal epithelial cell lineages and to establish the neurohormonal profile of the endocrine lineage. The histochemical staining methods and the applied antibodies for immunohistochemistry are listed in Table 1. Immunohistochenical staining results were evaluated with appropriate positive and negative controls. 
Table 1. Applied staining techniques.

Histochemistry

Grimelius, Periodic-acid Schiff (PAS, with/without diastase pretreatment), Alcian Blue (pH 2.4), High-Iron-Diamine Alcian Blue (HID-AB)

Applied Antibodies (nature, source, type, dilution)

\section{Intestinal Differentiation Markers}

-Enterocytes

-Goblet cells

-Endocrine cells

-Paneth cells

-General marker

\section{Hormonal Profile}

-Gastrointestinal-Colon

-Extra-intestinal

-Gastrointestinal-Other

作

Sucrase-Isomaltase*

Secretory Component

Mucin (Parlam 3/9, 13)

Chromogranin A

Chromogranin A/B

Synaptophysin

NSE

Leu-7

EGC

Lysozyme

CEA (Parlam 4)

Serotonin (5-HT)

Somatostatin

Glicentin

Substance P

PYY

Gastrin

Bombesin

Insulin

Glucagon

Pancreas Polypeptide

Neurotensin

$\mathrm{BHCG}$

aHCG

$\mathrm{ACTH}$

Growth Hormone
HBB2/614/88-mc-1:16000

DAKO-pc-1:1000

own lab-mc-1:1000/2000

Hybritech-mc-1:12500

Milab-pc-1:2560

Progen-mc-1:500

DAKO-pc-1:1000

BD-me-1:50

Milab-pc-1:400

DAKO-pc-1:2500

own lab-mc-1:1000 own lab-pc-1:2000

own lab-pc-1:1500

ED-pc-1:200

Milab-pc- $1: 600$

ED-pc- $1: 50$

own lab-pc-1:250

ICN-pc-1:10000

own lab-pc-1:1500

own lab-pc-1:500

own lab-pc-1:250

Amersham-pc-1:2000

DAKO-pc-1:2000

own lab-pc-1:3000

own lab-pc-1:100

Progen-pc-1:8000

III. 2nd Antibodies
Swine-anti-rabbit
DAKO-1:150
Rabbit-anti-mouse
DAKO-1:200

*Generous gift of Dr. H.P. Hauri, Biozentrum der Universität, Basel, CH. 


\subsubsection{Electron microscopy}

Tissues were fixed for 2 hours in $2.5 \%$ buffered glutaraldehyde, postfixed during 1 hour in $1.0 \%$ osmiumtetroxide (both in $0.1 \mathrm{M}$ phosphate buffer), dehydrated in graded ethanol series and embedded in Epon. Ultrathin sections were stained with uranyl acetate and lead citrate.

\subsubsection{Receptor assay}

The presence of somatostatin receptors was determined on cultured $\mathrm{CaCO}-2$ and $\mathrm{CaCO}-2$ EJ6 cells. For this purpose, ${ }^{125} \mathrm{I}$ labeled octreotide (a long acting somatostatin analogue),

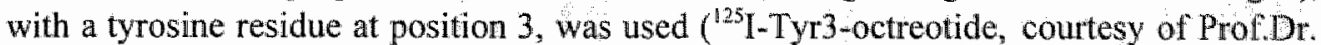
S.W.J. Lamberts, Dept. of Internal Medicine, Erasmus University, Rotterdam). Briefly, $5 \times 10^{5}$ tumor cells were seeded in a 6-well tissue cuiture dish and cultured for 3 days under standard conditions. After washing in PBS, the cells were incubated (2hrs., RT) with $400 \mu \mathrm{l}$ of receptor stabilizing buffer $\left(170 \mathrm{mM}\right.$ Tris, $5 \mathrm{mM} \mathrm{MgCl}_{2}, 10 \mu \mathrm{g} / \mathrm{ml}$ bacitracin, $1 \% \mathrm{BSA}$, pH 7.4) containing $1 \mathrm{nM}$ radiolabeled ligand with or without a 5000 -fold excess of unlabeled competitor (somatostatin-14). After washing steps (2X receptor stabilizing buffer, $1 x$ PBS) the cells were trypsinized and again washed in PBS. Radioactivity was determined with a $\tau$-counter. The receptor content was calculated from the amount of specifically bound radioligand, and expressed as the number of binding sites per cell.

\subsubsection{Quantification and statistical analysis of endocrine cells}

The number of endocrine cells in xenografts of Caco-2 and Caco-2 EJ6 was assessed by counting immmunoreactive tumor cells in $4 \mu \mathrm{m}$ thick sections of xenografts immunostained for chromogranin A. The density of endocrine cells was expressed per $\mathrm{mm}^{2}$ surface area of tumor. Using a gridded eyepiece, at a magification of $312.5 \mathrm{x}, 30$ contiguous random fields of tumor were scored, representing a total surface area of 120 $\mathrm{mm}^{2}$ per tumor ( $\mathrm{n}=3$ for both cell lines). Scores were statistically compared by t-tests for independent groups with separate variances.

\subsection{RESULTS}

\subsubsection{Caco-2 cells}

In vitro Caco-2 cells grew in monolayers of columnar cells with formation of domes (Fig. 1). In extracellular matrix gells glandular structures lined by flattened or cuboidal cells were formed (Fig. 2). In vitro, endocrine differentiation was not observed in Caco2 cells. None of the applied tissue culture modifications induced endocrine differentiation. 


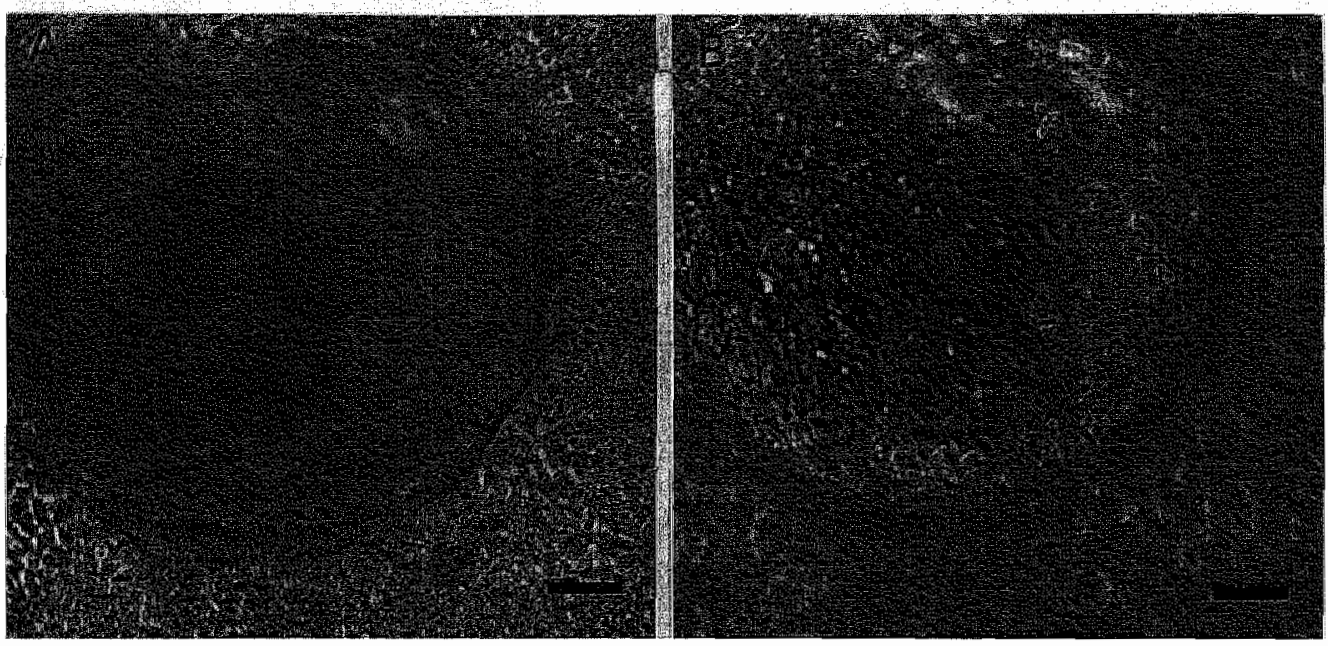

Figure 1. Phase-contrast mierographs of Caco-2 cells in vitro.

Cells grown as confluent monolayers form domes. A. Focussed on the monolayer. B. Focussed on the surface of the dome. Caco-2 EJ6 shows identical morphology in vitro; bar $=120 \mu \mathrm{m}$.

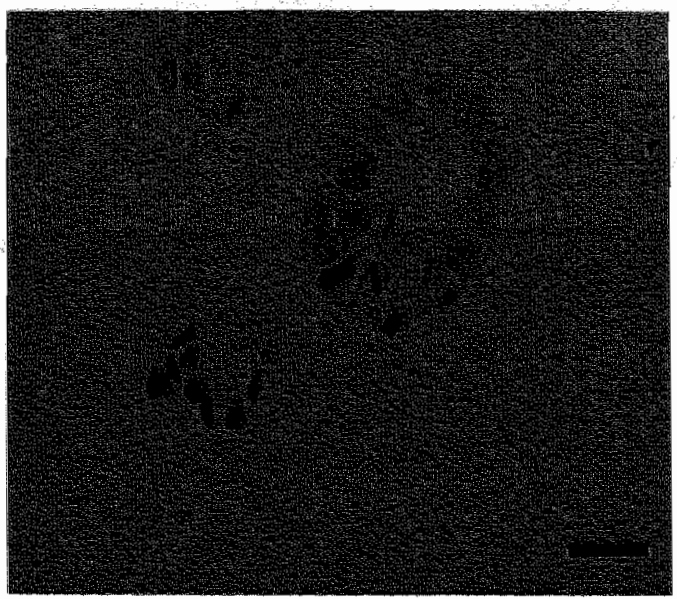

Figure 2. Three dimensional growth of Caco-2 EJ6 in Matrigel.

Cells are arranged in glandular formations lined by columnar cells. The same growth pattern was observed for Caco-2 cells. $\mathrm{H} \& \mathrm{E}, b a{ }^{*}=25 \mu \mathrm{m}$

Under standard xenografting conditions Caco-2 cells did not yield tumors (Table 2). The tumor take rate could be increased by inoculating Caco-2 cells in soluble Vitrogen 100 or as solid Vitrogen 100 collagen gels. Treatment of the animals with an antibody eliminating $\mathrm{NK}$ cell activity also improved the take rate. Xenografting of $\mathrm{Caco}-2 \mathrm{CO}$ 
and Caco-2 $\mathrm{CO} 2$ cells (containing the wild type Ras oncogene) and of Caco-2 D5 Neo cells (containing the empty plasmid) did not result in tumor growth under standard conditions. The tumors obtained after xenografting Caco-2 cells were moderatelywwell differentiated adenocarcinomas with expansive growth, without evidence of invasion (Fig. 3).

Table 2. Tumor take rate upon xenografting under various conditions.

\begin{tabular}{lcccc}
\hline Cell line & $\begin{array}{c}\text { Standard } \\
\text { conditions }\end{array}$ & $\begin{array}{c}\text { Vitrogen } 100 \\
\text { gell }\end{array}$ & $\begin{array}{c}\text { Vitrogen } 100 \\
\text { soluble }\end{array}$ & $\begin{array}{c}\text { Vitrogen } \\
+\alpha A S O M 1\end{array}$ \\
\hline Caco-2 & $0 / 8$ & $3 / 3(12)$ & $1 / 1(19)$ & $2 / 2(2)$ \\
Caco-2 EJ6 & $14 / 14(4)$ & $3 / 3(4)$ & $1 / 1(5)$ & $1 / 1(2)$ \\
Caco-2 COI & $0 / 2$ & n.t. & n.t. & n.t. \\
Caco-2 CO2 & $0 / 2$ & n.t. & n.t. & n.t. \\
Caco-2 DS Neo & $0 / 3$ & n.t. & n.t. & n.t. \\
\hline
\end{tabular}

No. of animals with tumors obtained per total no. of animals inoculated; the latency time in weeks is indicated between brackets; n.t. $=$ not tested.

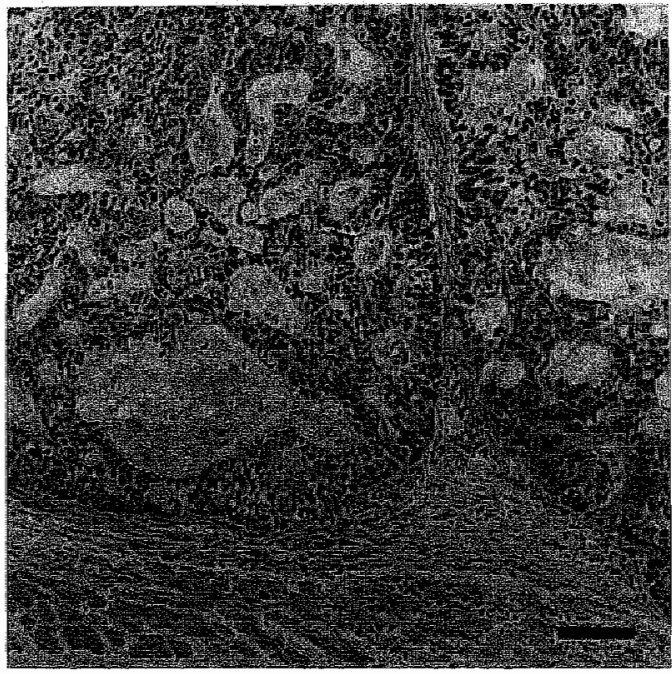

Figure 3. Subcutaneous xenograft of Caco-2 EJ6 in nude mouse.

The histological pattern is representative for botth native and transfected cells and shows a moderately well-differentiated adenocarcinoma with expansive growth, not invading neighbouring skeletal muscle. $\mathrm{H} \& \mathrm{E}, b a r=100 \mu \mathrm{m}$.

\subsubsection{Caco-2 EJ6 cells}

Of the cell lines obtained after transfection of $\mathrm{Caco-2}$ cells with point mutated $\mathrm{c}-\mathrm{Ha}$ Ras, Caco-2 EJ6 cells showed the highest level of Ras expression, and therefore these cells were further characterized. Southern blot analysis confirmed the integration of 


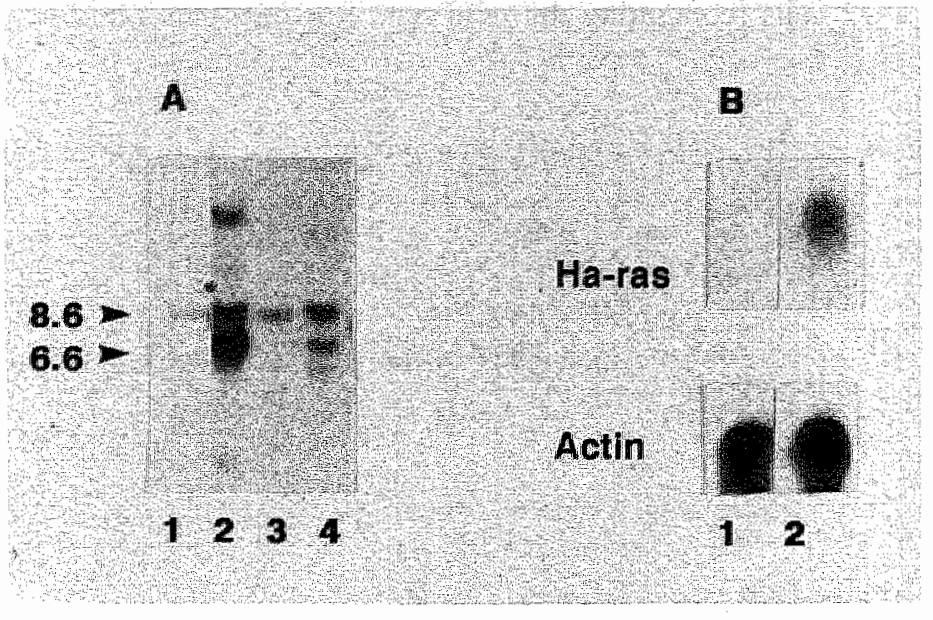

Fig. 4. Integration and expression of $\mathrm{pSV}_{2}$ neoEJ in Caco-2 cells.

A. Southern blot Lane 1. Caco-2; 2. Caco-2 EJ6; 3. Caco-2 EJ7; 4. Caco-2 EJ8. Chromosomal DNA was digested with Bam HI and hybridized with the 3.0 Sac 1 fragment of the c-Ha-ras gene. The $6.6 \mathrm{~kb}$ Bam HI fragment of $\mathrm{pSV}_{2}$ neoEJ in Cacom2 $\mathrm{EJ} 6$ can be distinguished from the endogenous $8.6 \mathrm{~kb} \mathrm{Bam} \mathrm{HI}$ fragment of $\mathrm{CaCO}-2$. B. Northern blot. Lane 1. Caco-2, 2; Caco-2 EJ6.
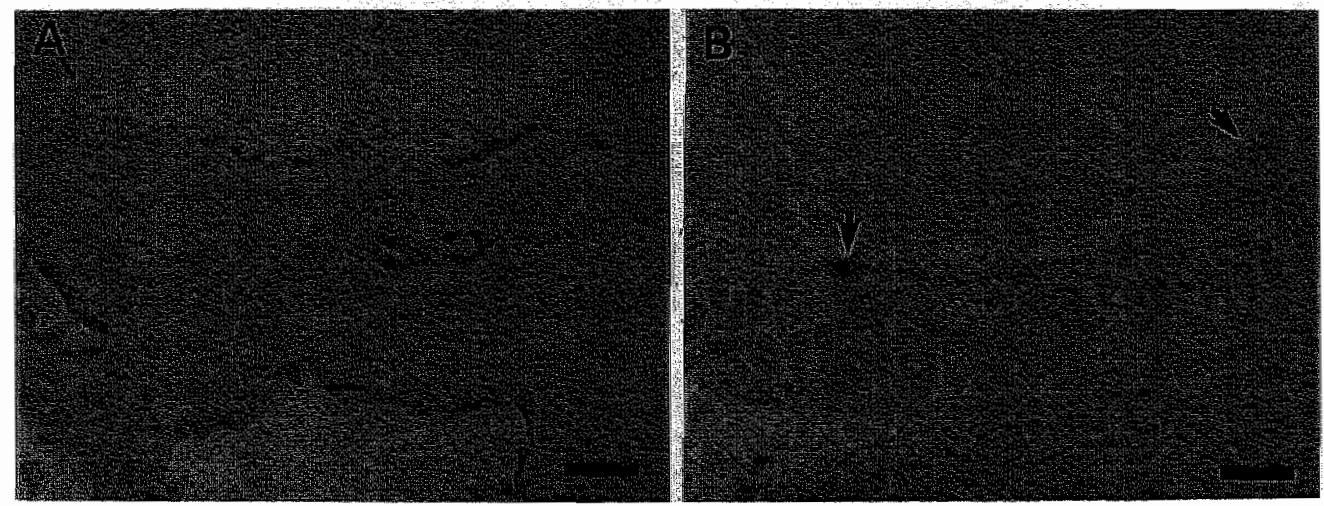

Figure 5. Enterocytic differentiation in vivo.

A. Frozen section of Caco-2 El6 xenograft showing apical luminal staining for the brush-border associated hydrolase sucrase-isomaltase. B. Caco-2 xenograft with focal cytoplasmic and apical staining of columnar cells for secretory component (arrows). Indirect immunoperoxidases with DAB; bars $=25$ $\mu \mathrm{m}$. 
the point mutated Ras oncogene (Fig. 4A). By Northern blot analysis, expression of $\mathrm{C}-$ Ha-Ras mRNA was clearly increased compared with normal Caco-2 cells (Fig. 4B). Caco-2 EJ6 cells in vitro were morphologically identical to native Caco-2 cells, and did not show endocrine differentiation either. As in Caco-2, the applied tissue culture variants did not induce endocrine differentiation in vitro.

In all xenografting conditions, except treatment with the QASGMI antibody, the growth properties of Caco-2 EJ6 were more favorable (higher take rate or shorter latency) than of untransfected Caco-2 (Table 2). Histologically, xenografts were identical to Caco-2 tumors, displaying the morphology of moderately well differentiated adenocarcinomas. Invasion was not observed. Cells representative of all intestinal cell lineages were present in xenografts from both the native and transfected cell line. Enterocytic differentiation in vivo was reflected in brush-border staining for sucrase-isomaltase and plasma membrane or cytoplasmic staining for secretory component (Fig. 5).

Both neutral (PAS staining after diastase pretreatment) and acid (Alcian Blue, pH 2.4) mucopolysaccharides could be demonstrated (Fig. 6). The HID-AB stains showed a combination of sulfo- and sialomucins. Immunohistochemically, the tumors showed reactivity for various mucin-associated antibodies. Both expression of Parlam 3/9, identifying a protein moiety of glycoproteins present in normal goblet cells, and of Parlam 13, identifying a carbohydrate epitope in glycoproteins increasingly expressed in neoplastic colonic epithelium (30), were found (Fig. 6).

Endocrine differentiation in Caco-2 EJ6 as well as Caco-2 xenografts was reflected in positive staining for several general neuroendocrine markers (Grimelius, chromogranin A, chromogranin A/B, synaptophysin, NSE) (Fig. 6). Variable numbers of endocrine cells were found, scattered between the other cells. No significant increase in the number of endocrine cells was noted in Caco-2 EJ6. (Endocrine cell density $2.04 / \mathrm{mm}^{2}$ (s.e.m. 0.42) for Caco-2 EJ6 vs. $1.76 / \mathrm{mm}^{2}$ (s.e.m. 1.10) for Caco-2; $\mathrm{p}=0.83$ ). Most endocrine cells were located peripherally in the tumor lobules, in direct contact with the extracellular matrix (Fig. 6 and Fig. 7A). Ultrastructurally, a well formed basal lamina was present at the epithelial-stromal interface (Fig. 7B). Complete loss of endocrine differentiation occurred within three passages when Caco-2 EJ6 tumor xenografts were explanted in vitro. Endocrine differentiation was restored upon renewed xenografting of the cultured cells. This effect was consistently seen in both early and late in vitro passages of Caco-2 EJ6. Because of the difficulties in xenografting, these experiments were not performed for Caco-2.

The neurohormonal profile of the endocrine cells in Caco-2 EJ6 and Caco-2 was restricted to somatostatin (Fig. 6) and PYY, which both occur in normal colonic enteroendocrine cells $(31,32)$. Other colorectal endocrine secretory products $(5-\mathrm{HT}$, glicentin, substance-P) were not identified. Focal expression of $\alpha \mathrm{HCG}$ was found. Neither hormone production indigenous to other gastrointestinal sites (gastrin, bombesin, neurotensin, glucagon, insulin, pancreatic polypeptide), nor ectopic hormone production (ACTH, growth hormone) were found. Both Caco-2 and Caco-2 EJ6 in vitro 


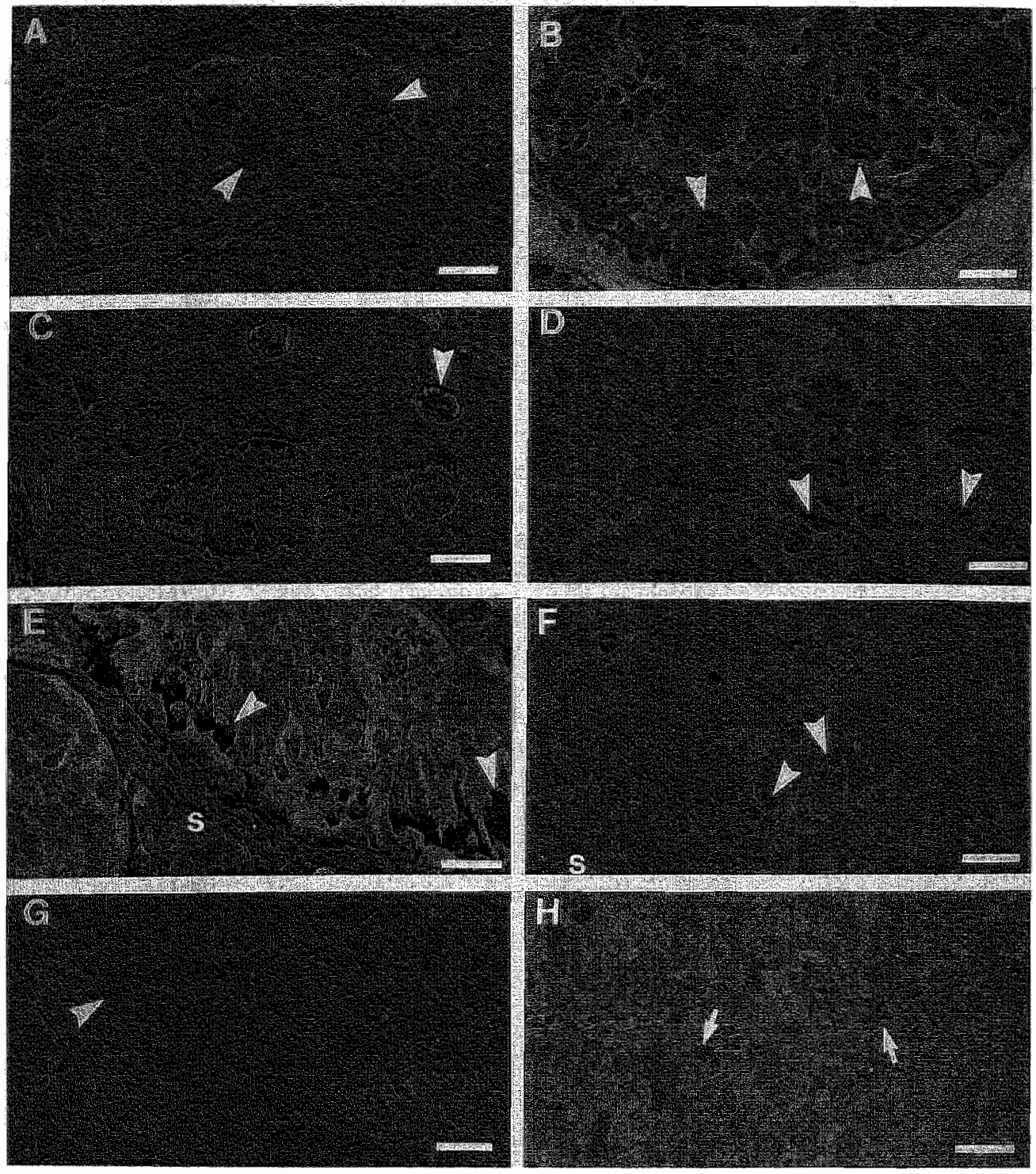

Figure 6 A-H. Mucin production and endacrine differentiation in subcutaneous xenografts of both Caco-2 and Caco-2 EJ6.

A. Neutral mucopolysaccharides (PAS after diastase pretreatment) B. Acid mucopolysaccharides (Alcian Blue, pH 2.4) C. Sulfomucins (white arrows) and sialomucins (black arrows) (HID-AB) D. Goblet cell mucin glycoptoteins (Parlam 3/9) E, F. Endocrine cells, peripherally in tumor llobules, in contact with stroma $(s)$; Grimelius $(B)$ and chromogranin A $(F)$ G. Neuron specific enolase H. Focal immunoreactivity for somatostatin. Arrows indicate immunoreactivity; bar in $\mathbf{C}, 56=\mu \mathrm{m}$; $a / l$ other bars $=28 \mu \mathrm{m}$. 

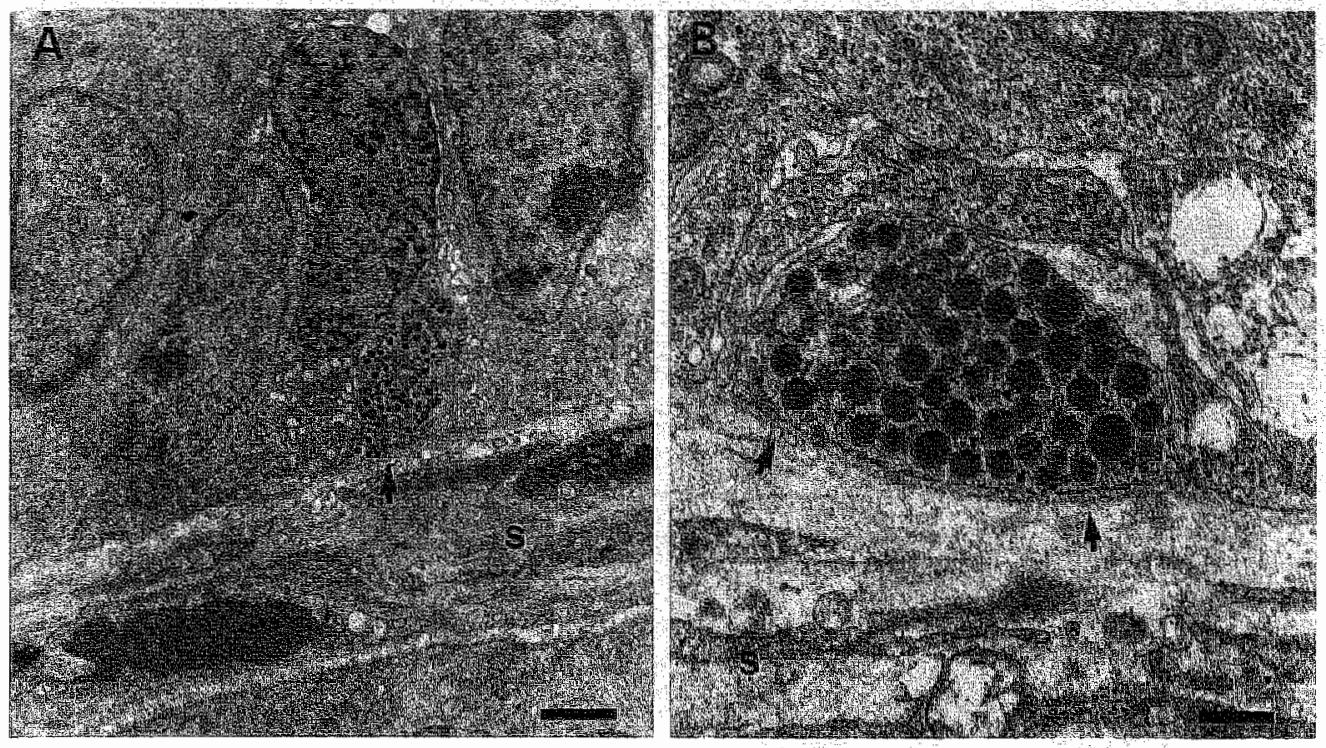

Figure 7. Ultrastructural morphology of Caco-2 EJ6 xenograft.

A. Endocrine cell containing neurosecretory granules (arrow) in contact with extracellular matrix (s); $b a r=2.3 \mathrm{~km}$. B. Well-developed basal lamina (arrows) at the interface of stroma (s) and tumor cells, of which one contains dense core granules; bar $=490 \mathrm{~nm}$.

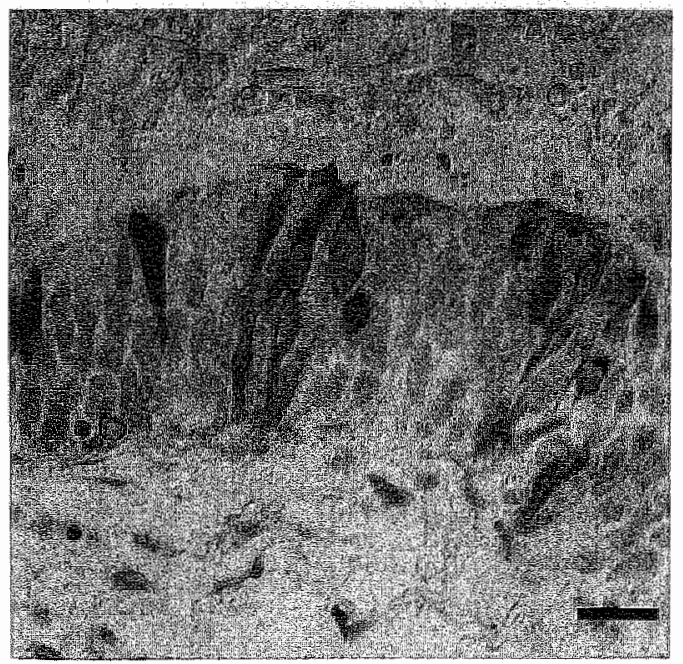

Figure 8. Cluster of Caco-2 cells with Paneth cell differentiation.

Lysozyme; bar $=25 \mu \mathrm{m}$ 
demonstrated specific binding of the long-acting somatostatin analogue octreotide, with approximately 1900 and 800 binding sites per cell, respectively.

In addition to expression of markers for the three normal colorectal cell lineages, Paneth cell differentiation (lysozyme) (Fig. 8) and CEA production (Parlam 4)(33) (Fig. 9) were found.

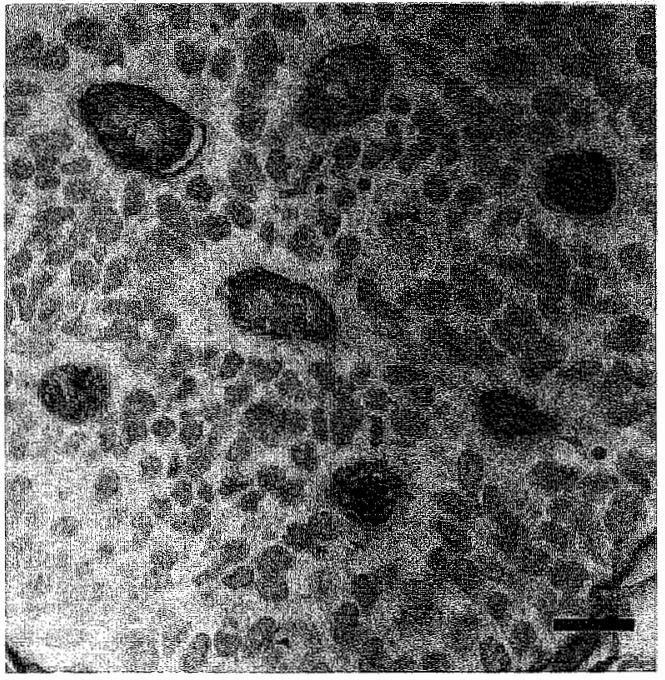

Figure 9. Intraluminal staining for $\mathrm{CEA}$ in a xenograft of Caco-2.

Parlam 4; bar $=25 \mu \mathrm{m}$.

\subsection{DISCUSSION}

The colon adenocarcinona cell line Caco-2 in vitro forms monolayers of polarized enterocyte-like cells with tight junctions, well developed brush-border-membranes with associated hydrolases (34), and domes (35). The cell line has been frequently applied as a model to explore intestinal physiology and pathology, e.g. secretory processes (36); uptake and transport of electrolyles (37), nutrients (38-43) and drugs (44); activity, transport and organization of small and large intestinal enzymes (45-48); and intestinal infections (49-51). Under standard conditions in vitro, we did not find endocrine differentiation in Caco-2 cells. However, in xenografts, which only could be attained by inoculating tumor cells in collagen gel or by suppressing NK cell activity in recipient animals, large numbers of endocrine cells could be demonstated. To our knowledge, endocrine differentiation has not been previously recorded in Caco-2 cells. In view of the difficulty encountered in obtaining $\mathrm{CaCo}-2$ xenografts, we decided to transfect Caco2 cells with a point mutated c-Ha-Ras gene, because of the reported association between overexpression of the point mutated c-Ha-Ras gene and tumor progression (15-17). Furthermore, these experiments would allow us to test wether or not overexpression of a 
point mutated Ras gene might induce or enhance endocrine differentiation. The latter question cerived from experiments by Nakagawa et al. (18) and Mabry et al. (19), who demonstrated enhanced endocrine differentiation in medullary thyroid carcinoma cells and in small cell lung cancer cells respectively after transfection with w-Ha-Ras. After transfection and selection a cell line was obtained which showed overexpression of the c-Ha-Ras oncogene at the mRNA level: Caco-2 EJ6. This cell line showed improved growth in vivo: co-injection of extracellular matrix components was not necessary and the latency period was considerably shorter than that of Caco- 2 cells.

We consider the improved take rate to be a result of the overexpression of the point mutated Ha-Ras oncogene and not the result of the transfection procedure, because xenografting of cells transfected with the wild type oncogene or the empty plasmid did not result in tumor formation under standard conditions.

In xenografts of Caco-2 and Caco-2 EJ6 endocrine differentiation occurred to a similar extent. Evidently, the potential for endocrine differentiation was not enhanced by overexpression of the c-Ha-ras oncogene. This finding supports an earlier report indicating that there is no correlation between increased Ras oncogene expression and endocrine differentiation in colonic neoplasms (52). The hormonal profile in both cell lines was identical and corresponded with hormone expression of normal colonic endocrine cells. In both cell lines endocrine cells produced immunohistochemically detectable somatostatin and specific somatostatin binding sites were found. Inhibition of growth of a colorectal adenocarcinoma cell line by somatostatin has been reported (53). This makes Caco-2 and Caco-2 EJ6 cells of potential interest to study autocrine or paracrine regulation of colorectal tumor growth.

On the basis of our observations we hypothesize that in Caco-2 and Caco-2 EJ6 cells, stromal factors in xenografts induce the endocrine phenotype, as has been observed for HRA-19 and NCI-H716 cells. Circumstantial evidence in favor of this hypothesis can be summarized as follows. Firstly, endocrine cells were found preferentially at the periphery of tumor lobules, apposed to the extracellular matrix, with a well developed basal lamina at the interface. Secondly, in vitro cell cultures of Caco-EJ6 xenografts indicate that endocrine differentiation in vivo is most likely a matter of differentiation induction and not of selection, because endocrine cells rapidly disappeared in vitro but reappeared when cells were again xenografted in nude mice. However, it is unclear which stromal components are involved. In preliminary experiments we were unable to induce endocrine differentiation in vitro by specific extracellular matrix components, which have been shown to enhance endocrine differentiation in vitro in NCl-H7l6 cells. The ability to induce endocrine differentiation in vitro therefore might depend on the level of differentiation of the cell line under investigation, because Caco-2 cells in this respect resemble HRA-19 cells, which also display a moderately well differentiated phenotype and do not show endocrine features in vitro either.

In conclusion, we have shown that endocrine differentiation occurs in xenografts of Caco- 2 cells. Endocrine differentiation is not enhanced by overexpression of the c-HaRas oncogene. Growth properties in vivo, however, are improved by overexpression of 
a (transfected) c-Ha-Ras oncogene. The obtained cell line, Caco-2 EJ6, is a useful addition to the available colorectal cancer cell lines in which endocrine differentiation can be induced in vivo and/or in vitro. 


\subsection{REFERENCES}

1. Oberndorfer S: Uber die kleinen Dunndarmearcinome. Verh. Dtsch. Ges. Path. 1907; 11: $113-116$.

2. Damjanov 1, Amenta PS, Bosman FT: Undifferentiated carcinoma of the colon containing exocrine, neuroendocrine and squamous cells. Virchows. Arch. A. 1983; 401:57*66.

3. Redman $B G$, Pazdur $\mathbb{R}$ : Colonic small cell undifferentiated carcinoma: a distinct pathological diagnosis with therapentic implications. An. J. Gastroenterol. 198\%, 82: $382-385$

4. Bosman FT, de Bruine A: Endocrine cells in non-endocrine tumors of the gut and pancreas. In: Dayal $\mathrm{Y}$, ed. Endocrine pathology of of the gut and pancreas. Boca Raton Ann Arbor Boston: CRC Press, 1991:319-338.

5. Ho SB, Itzkowitz SH, Friera $A M$. Jiang $\mathrm{SH}$, Kim $Y S$ : Cell lineage markers in premalignant and malignant colonic mucosa. Gastroenterology 1989; $97: 392-404$.

6. Arends $J W$, Wiggers $T$, Verstijnen $K$, Bosman FT: The occurrence and clinicopathological significance of serotonin immunoreactive cells in large bowel carcinoma. J. Pathol. 1986; 149: $97-1102$.

7. Jansson $\mathrm{D}$, Gould VE, Gooch $\mathrm{GT}$, ef al: Immunohistochemical analysis of colon carcinomas applying exocrine and neuroendocrine markers. Apmis. 1988; 96:1129-1139.

8. Johinson LR: Regulation of gastrointestinal mucosal growth. Physiol. Rev. 1988; 68: $456-502$.

9. Hoosein NM, Kiener PA, Curry RC, Brattain MG: Evidence for autocrine growth stimulation off cultured colon tumor cells by a gastrin/cholecystokinin-like peptide. Exp. Cell. Res. 1990; 186: 15-21.

10. Kirkland SC: Endocrine differentiation by a human rectal adlenocarcinoma cell line (HRA-19). Differentiation. 1986; 33: 148-155.

11. de-Bruine AP, Dinjens WN, Pijls MM, et al: NCI-H716 cells as a model for endocrine differentiation in colorectal cancer. Virchows. Arch. B. Cell, Pathol. 1992; 62:311-320.

12. Del-Buono $\mathrm{R}$, Pignatelli $\mathrm{M}$, Hall PA: Control of differentiation in a rectal adenocarcinoma cell line: the role of diffusable and cell-associated factors. J. Pathol. 199I; 164:59-66.

13. de-Bruīne AP, Dinjens WNM, van der Linden EPM, et al: Extracelular matrix components induce endocrine differentiation in vitro in NCI-H716 cells. Am. I. Pathol. 1993; 142: $773-782$.

14. Rousset M: The th thman colon carcinoma cell lines HT-29 and Caco-2; two in vitro models for the study of intestinal differentiation. Biochimie. 1986:68:1035-1040.

15. Fearon ER, Vogelstein B: A genetic model for colorectall tumorigenesis. Coil. 1990; 61: $759-767$

16. Muschel RJ, Williams JE, Lowy DR, Liotta LA: Harvey ras ind uction of metastatic potential depends upon oncogene activation and the type of recipient cell. An. J. Pathol. 1985, 121: $1-8$.

17. Lebeat J, Le-Chalony C. Prosperi MT, Goubin G: Constitutive overexpression of a $894 \mathrm{kDa}$ heat shock protein gene in the HBL100 human mammary cell line converted to a tumorigenic phenotype by the EJ/T24 Harvey-ras oncogene. Oncogene. 1991; 6: 1125-1132.

18. Nakagawa $T$, Mabry $M$, de-Bustros A, Ihle JN, Nelkin BD, Baylin SB: Introttuction of v-Ha-ras oncogene induces differentiation of cultured human medullary thytoid carcinoma cells. Proc. Natl. Acad. Sei. U. S. A. 1987; 84: 5923-5927. 
19. Mabry M, Nakagawa $T$, Baylin $S$, Pettengill $O$, Sorenson $G$, Nelkin $B$ : Insertion of the c-Ha-ras oncogene induces differentiation of calcitonin-producing human small cell lung eancer: J. Clin. Invest. 1989:84: 194-199.

20. Southern PJ. Berg P. Transformation of mammallian cells to antibiotic resistance with a bacterial gent under control of the $\$$ V40 early region promoter. J. Mol. Appl. Genet. 1982; 1: $327-341$.

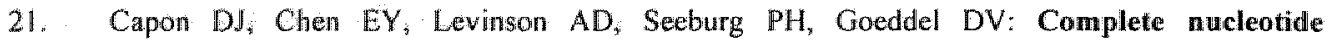
sequences of the "T24 human bladder carcinoma oncogene and its normal homologue. Nature. 1983; $302: 33-37$.

22. Parada LF, Tabin $\mathrm{CJ}$, Shih $\mathrm{C}$, Weimberg RA: Human EJ bladder carcinoma oncogene is homollogue of Harvey sarcoma virus ras gene. Nature. 1982; $297 ; 474-478$.

23. Sambrook J, Vritsch EF, Mantiatis T: Molecular cloning. second ed. New York: Cold Spring Harbor Laboratory Press, 1989.

24. Graham $\mathrm{FL}$, van der $\mathrm{Eb} \mathrm{AJ}$ : A new technique for the assay of infectivity of human adenovirus 5 DNA. Virology 1973; 52: 456-467.

25. Chen $C$, Okayama $\mathrm{H}$ : High-efficiency transformation of mammalian cells by plasmid DNA. Mol. Cell. Biol. 1987; 7: 2745-2752.

26. Feinberg AP, Vogelstein B: "A technique for radiollabeling DNA restriction endonuclease fragments to high specific activity". Addend um. Anal. Biochem. 1984; 137: 266-267.

27. Moerkerk PT, Kessels HJ, ten-Kate J, de-Goeij AF, Bosman FT: Southern and dot blot analysis of DNA from formalin-fixed, paraffin-embedded tissue samples from colonic carcinomas. Virchows. Arch. B. Cell. Pathol. 1990; 58: $351 \times 355$.

28. Liotta LA, Lee CW, Morakis DJ: New method for preparing large surfaces of intact human basement membtane for tumor invasion studies. Cancer. Lett. 1980;11:141-152.

29. Dinjens WN, Ten-Kate J, Kirch JA, ef al: Adenosine deaminase complexing protein (ADCP) expression and metastatic potential in prostatic adenocarcinomas. J. Pathol. 1990; 160: 195-201.

30. Verstijnen CPHJ, Arends JW, Moerkerk PTM, Pijls M, Kuypers-Engelen B, Bosman FT: Colonic epithelium reactive monoclonal antibodies. Identification and immunohistochemical localization of the target epitopes. Histochemistry. 1989; 92: 397-406.

31. Sjolund $K$, Sanden $G$, Hakanson $R$, Sundler $F$ : Endocrine cells in human intestine: an immunocytochemicall study. Gastroenterology $1983 ; 85: 1120-1130$.

32. Sundler $F$, Bottcher $G$, Fikblad $E$, Hakanson $R$ : The newroendocrine system of the gut. Acta. Oncol. 1989; 28: 303-314.

33. Verstijnen CP, Arends JW, Moerkerk PT, Warnaar S, Hilgers J, Bosman FT: CEA-specificity of CEA-reactive monoclonal antibodies. Immunochemical and immunocytochemical studies. Anticancer. Res. 1986; 6: 97-104.

34. Yoshioka M, Erickson RH, Matsumoto H, Gum E, Kim YS: Expression of dipeptidyl aminopeptidase IV during enterocytic differentiation of human colon cancer (Caco-2) cells. Int. J. Cancer. 1991; 47: 916-921.

35. Ramond $M J$, Martinot-Peignoux $M$, Erlinger $S$ : Dome formation in the human colon carcinoma cell line Caco-2 in culture. Influence of ouabain and permeable supports. Biol. Cell. $1.985 ; 54: 89-92$.

36. Chang EB, Bookstein $C$, Vaandrager A, DeJonge HR, Buse J, Musch MW: Cystic fibrosis transmembrane regulator mRNA expression relative to ion-nutrient transport in spontaneously differentiating human intestinal CaCo-2 epithelial cells. J. Lab. Clin. Med. $1991 ; 118 ; 377-381$ 
37. Watson $\mathrm{AJ}$, Levine $\mathrm{S}$, Donowitz $\mathrm{M}$, Montrose $\mathrm{MH}$ : Kineties and reguhtion of a polarized $\mathrm{Na}(+)-\mathrm{H}+$ exchanger from $\mathrm{Caco}-2$ cells, a human intestinal cell line. Am. J. Physiol. 1991 : 261: G229-G238.

38. Heyman M, Crain-Denoyelle AM, Nath SK, Desjeux JF: Quantification of protein transcytosis in the human colon carcinoma cell lime CaCo-2. J. Cell. Physiol 1990; 143 ; $391-395$.

39. Field $\mathrm{FJ}$, Albright $\mathrm{E}$, Mathur $\mathrm{S}$ : Inhibition of acylcoenzyme A: cholesterol acyluransferase activity by PD128042: effect on chollesterol metabolism and secretion in CaCom2 cells. Lipids. 1991; $26: 1-8$.

40. Mason $₫ B$, Shoda $\mathbb{R}$, Haskell $M$, Selhub J, Rosenberg $1 \%$ : Carrier affinity as a mechanilism for the $\mathrm{pH}$-dependence of folate transport in the small intestine. Biochim. Biophys. Actit. 1990; 1024: $331-335$.

41. Riley SA, Warhurst G, Crowe PT, Tumberg LA: Active hexose transport across cultured human Caco-2 cells: characterisation and influence of culture conditions. Biochim. Biophys. Acta. 1991; 1066: 175-182.

42. Smith TK, Gibson $\mathrm{CL}$, Howlin $\mathrm{BJ}$, Pratt JM: Active transport of amino acids by gamma-glutamyl transpeptidase through Caco-2 cell monolayers. Biochem. Biophys. Res. Commun. 1991; 178: 1028-1035.

43. Trotter PJ, Storch $\mathrm{J}$ : Fatty acid uptake and metabolism in a human intestinal cell line (Caco-2): comparison of apical and basolateral incubation. J. Lipid. Res. 1991; 32: 293-304.

44. Hilgers AR, Conradi RA, Burton PS: Caco-2 cell monolayers as a model for drug transport across the intestinal mucosa. Pharm. Res. 1990; 7: 902-910.

45. Jumarie $C$, Malo $C$ : Caco-2 cells cultured in serum-free medium as a model for the study of enterocytic differentiation in vitro. J. Cell. Physiol. 1991; 149:24-33.

46. Klumperman J, Boekestijn JC, Mulder AM, Fransen JA, Ginsel LA: Intracellular localization and endocytosis of brush border enzymes in the enterocyte-like cell line Caco-2. Eur. J. Cell. Biol. 1991; 54: 76-84.

47. Malagolini N, Dall'Olio F, Serafini-Cessi F: UDP-GalNAc:NeuAc alpha 2,3Gal beta-R (GalNAc to Gal) beta 1,4-N-acetylgalactosaminyltransferase responsible for the Sda specificity in human colon carcinoma $\mathrm{CaCo-2}$ cell line. Biochem. Biophys. Res. Commun. 1991; 180: $681-686$.

48. Matter $K$, Stieger $B$, Klumperman J, Ginsel $L$, Hauri HP: Fndocytosis, recycling; and lysosomal delivery of brush border hydrolases in cultured human intestimal epithelial cells (Caco-2). J. Biol. Chem. 1990; 265: 3503-3512.

49. Darfeuille-Michaud A, Aubel D, Chavivere $G$, et al: Adheston of enterotoxigenic Escherichia colt to the human colon carcinoma cell line Caco-2 in culture. Infect. Immuth. 1990; 58 : $893-902$.

50. Rigothie $\mathrm{MC}$, Coconnier $\mathrm{MH}$, Serwin $\mathrm{AL}$, Gayral $\mathrm{P}$ : A new in vitro model of Entamoeba histolytica adhesion, using the human colon carcinoma cell line Caco-2: seanning electron microscopic study. Infect. Immun. 1991; 59:4142-4146.

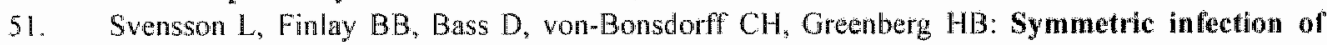
rotavirus on polarized human intestinal epithelial (Caco-2) cells. J. Virol. 1991; 65: $4190-4197$.

52. Jansson DS, Radosevich JA, Carney WP, ef al: An immunohistochemical analysis of ras oncogene expression in epithelial neoplasims of the colon. Cancer. $1990,65: 1329-1337$.

53. Smith IP, Solomon TE: Effects of gastrin, proglumide, and somatostatin on growth of human colon cancer. Gastroenterology 1988; 95: 1541-1548. 

GENERAL DISCUSSION 


\subsection{INTRODUCTION}

More insight in the mechanism(s) involved in metastasis of colorectal carcinoma cells might contribute to improved treatment of patients with colorectal cancer. To this effect relevant models must be employed to investigate the invasive and metastatic behavior of colorectal cancer. Orthotopic xenografting of human carcinoma cells in nude rnice appears to be a promising model for the study of invasion and metastasis (1). We investigated whether or not this approach could be employed to study in vivo behavior of human colorectal carcinoma cells by xenografting these cells in the cecum of nude mice. Furthermore, it was investigated whether in vitro parameters, known to be involved in invasion and metastasis, predicted in vivo behavior of colorectal carcinoma cells.

Human colorectal carcinoma cell lines were selected, on account of their in vivo behavior in the cecum of nude mouse, to study progression in colorectal cancer by transfection experiments with the c-Ha-ras oncogene, which has been implicated in the carcinogenesis of and progression in colorectal carcinoma. The highly differentiated, poorly tumorigenic $\mathrm{CaCo} 2$, and the undifferentiated, tumorigenic but non-invasive SW480 cell lines were chosen for this purpose. The association of tumor progression with karyotypic abnormalities prompted us to investigate the effects of transfection with the c-Ha-ras oncogene on the karyotype. Additionally, it was investigated whether or not changes were induced in vitro in cell functions, known to be involved in invasion and metastasis.

In this final chapter the results are briefly discussed in the context of the literature.

\subsection{ORTHOTOPIC XENOGRAFTS: \\ SUITABLE TO STUDY THE BEHAVIOR OF HUMAN COLORECTAL CARCINOMA CELLS?}

Human tumor cells in nude mice may display metastatic behavior after orthotopic xenografting, e.g. the implantation of some human renal carcinoma cell lines in the kidney environment yields metastasizing tumors (1). Likewise xenografting of some human colorectal carcinoma cell lines in the wall of the cecum yields invasive and metastatic tumors (2). In contrast, we never observed metastases after xenografting human colorectal carcinoma cells in the subcutis, which suggests that local tissue factors may modulate the expression of genes responsible for invasion and metastasis. Proteases and cell adhesion molecules have been implicated in invasion and metastasis $(3,4)$, but in our model their expression in vitro did not predict malignant behavior in vivo, except for the expression of the $\alpha_{2} B_{1}$ integrin, which was found to be high in cells invasive in vivo. However, the number of proteins involved in invasion and metastasis is much larger than the limited set we have investigated. A recent example is CD44, which is a transmembrane receptor for extracellular matrix proteins and involved in homing of lymphocytes (5). A variant form of CD44 is expressed in colorectal neoplasia but not in normal colon tissue (6). This form confers metastatic 
potential to rat carcinoma cells $(7)$ and is expressed in metastatic human colorectal carcinoma HT29 cells, but not in non-metastatic SW620 cells (8). Therefore, additional parameters might be studied in the orthotopic xenograft model in order to further elucidate the mechantsms involved in metastasis.

A disadvantage in the use of cell lines may be that they are not fully representative of primary tumors and their metastases, because from only $30 \%$ of primary cancers, cell lines can be obtained (9). Further selection of cells may occur during in vitro culturing, implying that cells loose or acquire characteristics after prolonged culturing. Orthotopic grafting of tumor tissue fragments into nude mice may circumvent these disadvantages. The take rate improves to $60 \%$ by orthotopic grafting of fragments of intact colon cancer tissue (10). Moreover, orthotopic grafting of gastric cancer tumor tissue yielded xenografts with metastatic behavior, which closely correlated with the clinical course of the tumors in patients (11). However, a main restrietion of model studies in nude mice is that effects of the immune system cannot be taken into account.

In conclusion, the mechanism(s) by which colorectal carcinoma cells metastasize can be studied with orthotopic xenografting of human colorectal carcinoma cell lines in nude mice. Further improvement is achieved by orthotopic grafting of intact primary tumor tissue.

\subsection{GENETIC INSTABILITY IN COLORECTAL CARCINOMA: THE INFLUENCE OF THE C-HA-RAS ONCOGENE}

Deviation of the DNA content from the diploid status to aneuploidy can be taken to indicate genetic instability. The incidence of aneuploidy, as measured by flow cytometry (12), is low $(6 \%-27 \%)$ in colorectal adenomas and high $(40 \%-70 \%)$ in colorectal carcinomas (13-16), which suggests that aneuploidy is a late phenomenon rather than a primary event in carcinogenesis. The clustering of high DNA-indices around a triploid- or tetraploid mode (12) suggests that aneuploidy may involve polyploidization with subsequent loss of chromosomes. Detailed cytogenetic analysis of short term cultures from colorectal carcinomas has shown two distinct types of karyotypic evolution (17). Most colorectal carcinomas demonstrated monosomy $17 p$ and monosomy 18 along with additional monosomies due to either unbalanced rearrangements or additional losses of chromosomes. The other colorectal carcinomas demonstrated trisomies involving several chromosomes, most frequently trisomy 7 , with either a monosomy $17 \mathrm{p}$ or a monosomy 18 . The presence of trisomies also suggests involvement of polyploidization along the route to aneuploidy (17). The use of interphase cytogenetics (18) allows further elucidation of genetic abnormalities directly at the level of colorectal cancer tissue, thus avoiding bias induced by the culture of cancer cells before cytogenetic analysis. This approach confirmed that trisomy 7 is a frequently occurring phenomenon in colorectal cancer cells '. A genetic model of colorectal carcinoma postulated a preferred order of genetic lesions, which included pointmutations in the $\mathrm{p} 21^{\text {ras }}$ genes as early events in the adenoma stage, and monosomy $17 \mathrm{p}$ representing a late event in the carcinoma stage, the latter most likely 
resulting in loss of one allele of the tumor suppressor gene $p 53(19,20)$. However, the total number of genetic lesions, rather than the order in which they accumulate, probably determines the biological properties of the tumor (20). This view is supported by the following observations: 1) Patients with multiple chromosomal abnomalities have a significantly shorter survival time than those with simple alterations $(21) ; 2$ ) Kiras pointmutation or $\mathrm{p} 53$ overexpression as single parameters does not correlate with survival in colorectal carcinoma, but together they predict a shorter survival time of patients (22).

The significantly higher presence of c-Ki-ras pointmutations in aneuploid colorectal carcinomas than in diploid colorectal carcinomas suggests that mutations in $\mathrm{p} 21^{\mathrm{ras}}$ proteins may be involved in the development of aneuploidy (23). This contention is supported by the increase in genetic instability observed in rat prostatic and mammary carcinoma cells and in our human colorectal carcinoma SW480 cells after introduction of the c-Ha-ras oncogene (24-26). However, pointmutated $\mathrm{p} 21^{\text {ras }}$ genes are not invariably associated with increased genetic instability, because the karyotype of human MSU1.I fibroblasts did not change after transfection with pointmutated $\mathrm{p} 2 \mathrm{I}^{\text {ras }}$ genes (27-29). Thus, the recipient cell is an important determinant of the effect of the c-Ha-ras oncogene on the karyotype.

We observed loss and gain of chromosomes, translocations, and acquisition of new marker chromosomes in SW480 cells transfected with ras-containing plasmids, which gave each transfectant a unique karyotype (26). The reported site-specific integration of the c-Ha-ras oncogene in rat embryo fibroblasts (30) prompted us to localize the chromosomal integration sites of plasmid DNA in SW480 transfected cell lines. To that effect, we developed a procedure by which chromosome banding was induced by either hot banding or a short trypsin treatment followed by fluorescence in situ hybridization (FISH). This combination allowed rapid and detailed identification of chromosome integration sites $(26,31)$. These were not associated with specific chromosomal regions but ras-containing plasmids were frequently located in new aberrant chromosomes. Most integration sites in aberrant chromosomes involved telomeric bands and were located at the translocation breakpoint. Our findings suggest that the introduction of exogenous DNA may destabilize chromatin locally, leading to new chronosome rearrangements, with plasmid DNA at the rearranged site (26). This also seens to be a likely scenario after integration in telomeric regions, where disruption of the telomeric structure results in fusogenic chromosome ends $(32,33)$. In conclusion, genetic alterations in $\mathrm{p} 21^{\text {ras }}$ genes are probably early events in the development of colorectal carcinoma, may increase the genetic instability of the tumor cells, and thus induce aneuploidy. 


\subsection{THE ROLE OF THE C-HA-RAS ONCOGENE IN COLORECTAL CARCINOMA: EFFECTS ON GROWTH AND DIFFERENTIATION}

The normal function of the c-Ha-ras gene may differ between cells, and its role in signal transduction may be related with proliferation as well as differentiation (34). To fully understand the role of the c-Ha-ras oncogene in carcinogenesis, the normal function of the c-Ha-ras gene must be elucidated.

Increased levels of GTP.p $21^{\text {ras }}$ are found in cells stimulated by growth factors, such as insulin (35), EGF (36-38), and PDGF (39), which stimulate mitogenesis (40). Thus, cells may divide continuously, thereby incorporating genetic errors (41) and in that way increase the genetic instability, if the level of GTP.p2 $1^{\text {ras }}$ is constitutively high. GTP.p2 $1^{\text {ras }}$ levels are regulated by proteins which stimulate the intrinsic GTPase activity of the GTP.p2 I ras protein. As yet, GAP (42) and NFI (43) are prototypes of these proteins. NF1 is a tumor suppressor gene (43), inactive in patients with neurofibromatosis type 1 (44). Cell lines derived from neurofibromatosis type 1 patients have increased levels of GTP.p2 $1^{\text {ras }}$ (45), which suggests that NF-1 downregulates GTP.p2 $11^{\text {ras }}$ levels. Pointmutations in codons 12,13 , and 61 of the $\mathrm{p} 21^{\text {ras }}$ genes render mutant $\mathrm{p} 2 \mathrm{I}^{\text {ras }}$ proteins inactive to the GTPase activating activity of GAP and NF-1 $(42,43,46)$. Thus, pointmutations in $221^{\text {ras }}$ genes might enable cells to divide contimuously, thereby abrogating normal regulation by the microenvironment, which confers growth autonomy. Reduced requirement for growth factors has indeed repeatedly been observed after transfection with the c-Ha-ras oncogene $(27,28,47-53)$. Also, growth autonomy has been reported to be one of the requirements for at carcinoma cell to metastasize $(54,55)$. In line with a role for the c-Ha-ras oncogene in conferring growth autonomy is the increase in tumorigenic potential of $\mathrm{CaCo} 2$ cells $(56,57)$. SW480 cells are tumorigenic by themselves. The fact that phenotypic alterations did not occur and invasive capacity was not acquired after transfection of SW480 cells with the c-Ha-ras oncogene might be taken as circumstantial evidence that pointmutated $\mathrm{p} 2 \mathrm{l}^{\mathrm{ras}}$ genes do not have a role in tumor progression in colorectall carcinoma. However, bearing in mind that functional differences between $\mathrm{p} 21^{1 \text { tis }}$ proteins might be lost upon mutation (58), the presence of a pointnutated c-Ki-ras gene in the genome of SW480 cells (59) could be an alternative explanation for the lack of phenotypic changes in c-Ha-ras oncogene transfected SW480 cells.

Tumor growth results from an imbalance between cell birth and cell death. Therefore, not only increased proliferation but also decreased cell death may cause tumor growth. One mechanism of cell death, programmed cell death or apoptosis, has recently attracted wide attention. It is a normal regulatory mechanism in development, as has been extensively demonstrated in C. elegans (60) and Drosophila (61). Also, the human immune system elliminates self-antigen recognizing cells by apoptosis, which is induced by glucocorticoids and is mediated by the glucocorticoid receptor (62). The mechanism of apoptosis has not been fully elucidated yet. An interesting aspect is the observation that GAP associates with a putative transcriptional repressor of the glucocorticoid receptor gene in mitogenically stimulated cells $(63,64)$. Downregulation of the glucocorticoid receptor gene by a pointmutated GTP.p2 $\|^{\text {ras }}$.GAP complex might 
thus inhibit apoptosis. This may be an alternative explanation for the tumor inducing effect of pointmutated c-Haras genes.

A role for the $\mathrm{c}-\mathrm{Ha}$-ras oncogene in the induction of endocrine differention, observed in human medullary thyroid carcinoma and small cell lung carcinoma cells $(65,66)$, was not supported by our results with the $\mathrm{CaCo} 2$ cell line (57). Whether or not $\mathrm{CaCo}$ 2 cells were transfected with the c-Ha-ras oncogene, endocrine differentiated cells were noted in vivo, specifically at the periphery of tumor lobules. However, endocrine differentiated cells were not observed in vitro, which emphasizes the importance of the microenvironment in the regulation of gene expression (57).

In conclusion, our results with CaCo 2 and SW 480 cells support the hypothesis that pointmutations in the c-Ha-ras gene may confer growth autonomy to colorectal cancer cells, but do not support a role for the pointmutated c-Ha-ras gene in the acquisition of invasive and metastatic potential of colorectal cancer cells.

\subsection{CONCLUSIONS}

To increase the knowledge about the mechanism(s) by which colorectal carcinoma cells invade and metastasize, we investigated whether or not the orthotopic xenograft model could be applied. Our results are in agreement with other studies (67-69) and show that a subset of the colorectal carcinoma cell lines investigated are invasive and metastatic. Therefore, this model is relevant for the study of invasive and metastatic human colorectal carcinoma cells. However, most in vitro parameters analyzed did not predict in vivo behavior of colorectal carcinoma cells. This can be attributed to the modulating influence of the microenvironment on gene expression, e.g. local tissue host factors in nude mice.

Pointmutations in $\mathrm{p} 2 \mathrm{l}^{\mathrm{ras}}$ genes have been implicated in carcinogenesis and tumor progression. Therefore, it was of interest to investigate the effect of transfection with the c-Ha-ras oncogene upon cell behavior of human colorectal carcinoma cells. Our results indicated that the genetic instability increased and suggested that tumorigenic behavior was induced. Both phenomena might have a common cause, namely disregulation of proliferation, which is likely to occur in view of the role of $\mathrm{p} 21^{\text {ras }}$ proteins in mitogenic signal transduction pathways. Invasive capacity was not acquired after transfection with the c-Ha-ras oncogene. Taken together, these data suggest a role for pointmutated $\mathrm{p} 2 \mathrm{l}^{\text {ras }}$ proteins early in colorectal carcinogenesis rather than in progression. 


\subsection{REFERENCES}

1. Fidler IJ, Naito S, Pathak S: Orthotopic implantation is essential for the selection, growth and metastasis of human renal cell cancer in nude mice. Cancer. Metastasis. $\mathbb{R e v}$, 1990; 9: 149-165.

2. de Vries JE, Dinjens WNM, Verspaget $\mathrm{HW}$, et al: Behavior of orthotopic human colorectal carcinoma xenografts in relation to in vitro invasion. Chapter 2 , this thesis.

3. Liotta LA, Steeg PS, Stetler-Stevenson WG: Cancer metustusis and angiogenesis: an imbalance of positive and negative regulation. Cell. 1991; 64:327-336.

4. Albelda SM: Role of integrins and other cell adhesion molecules in tumor progression and metastasis. Lab. Invest. 1993: 68:4-17.

5. Haynes BF, Telen MJ, Hale LP, Denning SM: CD-44 - A molecule involved in leukocyte adherence and T-cell activation. Immunology today 1989; 10:423-428.

6. Heider $\mathrm{K}-\mathrm{H}$, Hofmann $\mathrm{M}$, Hors $\mathrm{E}_{\text {, et }}$ al: A human homollogue of the rat metastasis-associated variant of CD44 is expressed in colorectal carcinomas and adenomatous polyps. J. Cell. Biol. 1993; 120:227-233.

7. Gunthert $U$, Hofmann $M$, Rudy $W$, et als A new variant of glycoprotein CD44 confers metastatic potential to rat carcinoma cells. Cell. 1991; 65: 13-24.

8. Hofinann $M$, Rudy $W$, Zoller $\mathrm{M}$, el al: CD44 splice variants confer metastatic behavior in rats:" homologous sequences are expressed in human tumor cell lines. Cancer. Resi 1991; 51: 5292-5297.

9. MeBain JA, Weese JL, Meisner LF, Wolberg WH, Willson JK: Esstablishment and characterization of human colorectal cancer cell lines. Cancer. Res. 1984; 44:5813 5821.

10. Fu XY, Besterman IM, Monosov A, Hoffunarn RM: Models of human metastatic colon cancer in nude mice orthotopically constructed by using histologically intact patient specimens. Proc. Natl. Acad. Sci. U. S. A. 1991; 88: 9345-9349.

11. Furukawa $T$, Kubota $T$, Watanabe $M$, Kitajima $M_{3}$ Hoffman RM: Orthotopic transplantation of histologically intact clinical specimens of stomach cancer to nude mice: Correlation of metastatic sites in nude mouse and individual patient donors. Int. Ji. Cancer. 1993; 53: 608-612.

12. Schutte $B$, Reynders MMJ, Wiggers $T$, et at: Retrospective analysis of the prognostic sïgnificance of DNA content and proliferative activity in large bowel carcinoma. Cancer. Res. 1987; 47: 5494-5496.

13. Armitage NC, Robins RA, Evans DF, Turner DR, Baldwin RW, Hardeastle ID: The influence of tumour cell DNA abnormalities on survival in colorectal cancer. Br. J. $5 u r g .1985 ; 72$ : 828-830.

14. van-den-Ingh $\mathrm{HF}$. Griffioen $\mathrm{G}$, Comelisse $\mathrm{CJ}$ : Flow cytometric detection of ancuploidy in colorectal adenomas. Cancer. Res. $1985 ; 45: 3392-3397$.

15. Wolley RC, Schreiber K, Koss LG, Karas M, Shermain A: DNA distribution in luman collon carcinomas and its relationship to clinical behavior. J. Natl. Cancer. Inst. 1982; 69:15-22.

16. Kokal W, Sheibani $K$, Terz J, Harada JR: Tumor DNA content in the prognosis of colorectal carcinoma. Jama. 1986;255:3123-3127.

17. Muleris M, Salmon RJ, Dutrillaux B: Existence of two distinct processes of chromosomal evolution in near-diploid colorectall tumors. Cancer. Genet. Cytogenet. 1988; 32: 43-50.

18. Poddighe PJ, Ramaekers FCS, Hopman AHN: Interphase cytogenetics of tumours. J. Pathol. 1992; 166: 215-224.

19. Vogelstein B, Fearon ER, Hamilton SR, et al: Genetic alterations during colorectal-tumor development. N. Engl. J. Med.. 1988; 319: 525-532.

20. Fearon ER, Vogelstein B: A genetic model for collorectal tumorigenesis. Cell. 1990; 61: 759-767. 
21. Bardi $\mathrm{G}$, Johansson $\mathrm{B}$, Pandis $\mathrm{N}$, ef al: Cytogenetic aberrations in collorectal adenotareinomas and their correlation with clinicopathologieal features. Cancer. 1993; 71 : 306-314.4.

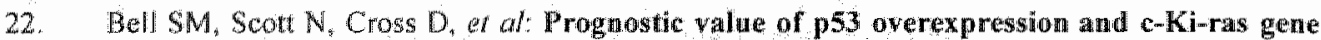
mutations in colorettall cancer. Gastroenterology $1993 ; 104: 57-64$.

23. Suchy $B$, Zietz $C$, Rabes HM: $K$-ras point mutations in human colorectal carcinomas: relation to aneuploidy and metastasis, Int. J. Cancer $1992 ; 52: 30-33$.

24. Jchikawa "T, Kyprianou N. Isaacs JT: Genetic instability and the acquisition of metastatic ability by rat mammary cancer cells following v-H-ras oncogene transfection. Cancer. Res. 1990: 50: 6349-6357.

25. Ichikawa $T$, schalken $J A_{*}$, rchikawa $Y$, Steinberg $G D$, Isaacs JT: H-ras expression, genetic instability, and acquisition of metastatic ability by rat prostatic cancer cells following w-H-ras oncogene transfection. Prostate. 1991; 18: 163-172.

26. de Vries JE, Komips FHAC, Marx P. Bosman FT, Geraedts JPM, ten Kate J: Transfected c-Ha-ras oncogene enhances karyotypic instability and integrates predominantly in aberrant ehromosomes. Cancer. Genet. Cytogenet. 1993; 100: 100.

27. Hurlin PJ, Maher VM, McCormick JJ: Malignant transformation of human fibroblasts caused by expression of a transfected T24 HRAS oncogene. Proc. Natl. Acad. Sci. U. S. A. 1989; 86:187-191.

28. Wilson DM, Yang DI, Dillberger JE, Dietrich SE, Maher VM, McCornick JJ: Malignant transformation of human fibroblasts by a transfected N-ras oncogene. Cancer. Res. 1990; 50: $5587-5593$.

29. Fry DO, Milam LD, Dillberger JE, Maher VM, McCormick JJ: Malignant transformation of an infinite life span human fibroblast cell strain by transfection with v-Ki-ras. Oncogene. $1990 ; 5: 1415-1418$.

30. McKenna WG, Nakahara K, Muschel RJ: Site-specific integration of H-ras in transformed rat embryo cells. Science. 1988; $241: 1325-1328$.

31. de Vries $\mathrm{JE}$, Kornips $\mathrm{FHAC}$, Wiegant $\mathrm{J}$, et al: Chromosomal locallization of transfected genes by a combination of hot banding and fluorescence in situ hybridization. $J$ Histochem. Cytochen. 1992; 40:1053-1058.

32. Hecht F. Hecht BK: The telomere in cancer. Cancer. Genet. Cytogenet. 1991; 54: 245-246.

33. Greider CW: Chromosome first aid. Cell. 1991; 67: 645-647.

34. Furth ME, Aldrich TH, Cordon-Cardo $\mathrm{C}$ : Expression of ras proto-oncogene proteins in normall human tissues. Oncogene. 1987; 1:47-58.

35. Burgering BMT, Medena RH, Masssen JA, ef al: Insulin stimulation of gene expression mediated by $\mathbf{p} 21$ ras activation. The EMBO Journal $1991 ; 10: 1103-1109$.

36. Buday $\mathrm{L}_{\mathrm{w}}$, Downward $\mathrm{d}$ : Epidermal growth factor regulates the exchange rate of guanine uucleotides on p21ras in fibroblasts. Mol. Cell. Biol. 1993; 13:1903-1910.

37. Satoh $T$, Endo $M$, Nakafuku $M$, Akiyama $T$, Yamamoto $T$, Kaziro $Y$ : Accumulation of p21ras «TP in response to stimulation with epidermal growth factor and oncogene products with tyrosine kinase activity. Proc. Natl. Acad. Sci. U. S. A. 1990; 87: 7926-7929.

38. Satoh $i$, Endo M, Nakafuku M, Nakanura S, Kaziro $Y$ : Platelet-derived growth factor stimulates formation of active p21ras.GTP complex in Swiss mouse 3 T3 cells. Proc. Natl. Acad. Sci. U. S. A. 1990; 87:5993-5997.

39. Gibbs JB, Marshall MS, Scolnick EM, Dixon RA, Vogel US: Modulation of guanine nucleotides bound to Ras in NIH3T3 cels by oncogenes, growth factors, and the GTPase activating protein (GAP). J. Biol. Chem. 1990; 265: 20437-20442.

40. Pusztai L, Lewis CE, llorenzen J, McGee JO'D: Growth factors: Regulation of normal and neoplastic growth. J. Pathol. 1993; 169: 191-201.

41. Cohen SM. Ellwein LB: Genetic errons, cell proliferation, and carcinogenesis. Cancer. Res. $1991: 51: 6493-6505$. 
42. Vogel US, Dixon RA, Schaber MD, al: Cloning of bovine GAP and its interaction with oncogenic ras p21. Nature: 1988; 335:90-93.

43. Xu GF, OConnell $\mathrm{P}$, Viskochil $\mathrm{D}$, el al The neurofibromatosis type 1 gene encodes a proteim related to GAP. Cell. 1990; 62:599-608.

44. Legius $E$, Marchuk DA, Collins FS, Glover TW: Somatic deletion of the neurofibromatosis type 1 gene in a neurofibrosarcoma supports a tumour supparessor gene hypothesis. Nature Genetics 1993; 3: 122-125.

45. Basi TN, Gutmann DH, Fletcher JA, Glover TW, Collins FS, Downward J: Alberrant regulation of ras proteins in malignant tumour cells from type 1 neurofibromatosis patients. Nature. 1992; 356:713-715.

46. Ballester R, Marchuk D, Boguski $M$, et al: The NFI locus encodes a protein functionally related to mammalian GAP and yeast IRA proteins. Cell. 1990; 63: 851-859;

47. Sirinian MI, Marchetti A, Rocco GD, Starace G, Jucker R, Nasi $S$ : Ras oncogemo transformation of human B lymphoblasts is associated with lymphocyte activation and with a block of differentiation. Oncogene. 1993; 8: 157-163.

48. Feramisco $\mathbb{R}$, Gross $M$, Kamata $T$, Rosenberg $M$, Sweet $R W$ : Microinjection of the oncogene form of the human H-ras $(\mathrm{T}-24)$ protein results in rapid proliferation of quiescent cells. Cell. 1984; 38: 109-117.

49. Stacey DW, Kung H-F: Transformation of NIH 3T3 cells by microinjection of Ha-ras p21 protein. Nature. 1984; $310: 508-511$.

50. Ricketts $\mathrm{MH}$, Levinson $\mathrm{AD}$ : High-level expression of c-H-ras1 fails to fully transfonm rat-1 cells. Mol. Cell. Biol. 1988; 8: 1460-1468.

51. Jankun $J$, Maher $V M$, McCormick JJ: Malignant transformation of human fibroblasts correlates with increased activity of receptor-bound plasminogen activator. Cancer. Res. 1991; 51: $1221-1226$.

52. Ciardiello $\mathbb{F}_{,}$McGeady $\mathrm{ML}, \mathrm{Kim} \mathrm{N}_{\text {, }}$ et al: Transforming growth factor-alpha expression is enhanced in human mammary epithelial cells transformed by an activated c-Ha-ras protooncogene but not by the c-neu protooncogene, and overexpression of the transforming growth factor-alplia complementary DNA leads to transformation. Cell. Growth. Differ. 1990; 1: 407-420.

53. Andrejauskas $\mathrm{E}$, Moroni $\mathrm{C}$ : Reversible abrogation of $\mathbf{L}-3$ dependence by an inducible H-ras oncogene. Embo. J. 1989; 8: 2575-2581.

54. Chadwick DE, Lagarde $\mathrm{AE}$ : Coincidental acquisition of growth autonomy and metastatic potential during the malignant transformation of factor-dependent CCL39 lung fibroblasts. J. Natl. Cancer. Inst. 1988; 80: 318-325.

55. Liotta LA: Growth autonony: The only requirement for metastasis? I. Natl. Cancer. Inst. $1988: 86: 18$.

56. de Vries $\mathrm{JE}_{\mathrm{E}}$ van Driel $\mathrm{M}$, Marx $\mathrm{P}$ et al: Phenotypic analysis of CaCo 2 and $\mathrm{SW} 480$ cell lines transfected with the c-Ha-ras oncogene. Chapter 5, this thesis.

57. de Bruine AP, de Vries JE, Dinjens WNM, et al: Human CaCo 2 cells transfected with c-Ha-ras as a model for endocrine differentiation in the large intestine. Differentiation. 1993; $53: 51-60$.

58. Bos IL: Ras oncogenes in human cancer: A review. Cancer. Res. 1989; 49; 4682-4689.

59. Capon DJ, Seeburg PH, MeGrath JP, el al: Activation of Ki-ras 2 gene in human colon and lung carcinomas by two different point mutationsin Nature. 1983; 304:507-513.

60. Vaux DL, Weissman IL, Kim SK: Prevention of programmed cell death in Caenorhabditis elegans by human Bcl-2. Science. 1992; 258: 1955-1957.

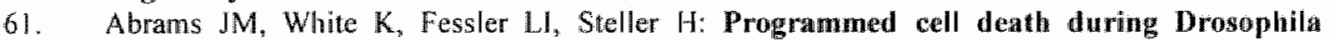
embryogenesis. Development 1993; 117:29-43.

62. Cohen JJ: Glucocorticoid-induced apoptosis in the thymus. Seminars in Immunology 1992; 4: $363-369$. 
63. Moran MF, Polakis $P$, MeCormick $F$, Pawson $T$, Ellis $C$ : Protein-tyrosine kinases negulate the phosphorylation, protein interactions, subeellular distribution, and activity of $\mathrm{p} 21$ ras GTPase-activaling protein. Mol. Cell. Blol. 1991: 11: 1804-1812.

64. Settleman $J$, Narasmhan $V$, Foster LC, Weinberg RA: Molecular cloning of cDNAs encoding the GAP-associated protein p190. implications for a signaling pathway from ras to the wuterus, Cell 1992,69:539-549.

65. Mabry M, Wakagawa $T$, Baylin $S$, Pettengall $O$, Sorenson $G$, Nelkin B: Insertion of the c-Ha-ras oncogene induces differentiation of calcitonin-producing human small cell lang cancer, J Clin. Invest 1989;84: 194-199.

66. Nakagawa T, Mabry $M$, de-Bustros $A$, thle JN, Nelkin BD, Baylin SB: Introduction of v-Halras oncogene induces differentiation of cultured human medullary thyroid carcinoma cells. Proc. Natl Acad Sci. U. S. A. 1987; 84:5923-5927.

67. Morikawa K. Walker SM, Nakajima M, Pathak S, Jessup JM, Fidler IJ: Influence of organ environment on the growth, selection, and metastasis of human colon carcinoma cells in nudle mice. Cancer. Res. 1988; 48:6863-6871.

68. Morikawa $\mathrm{K}$, Walker $\mathrm{SM}$, Jessup $\mathrm{JM}$, Fidler $\mathrm{IJ}$ : In vivo selection of highly metastatic cells from surgicall specimens of different primary human colon carcinomas implanted into nudle mice. Cancer. Res. 1988; 48: 1943-1948.

69. Bresalier RS, Raper SE, Hujanen ES, Kim YS: A new animal model for human colon cancer metastasis. Int. J. Cancer. 1987; 39:625-630. 


\section{SUMMARY}

The subject of this thesis has been the biological behavior of human colorectal carcinoma cells in various models and the influence of the c-Ha-ras oncogene on this behavior.

In Chapter 1 the characteristics of invasive and metastatic cells and their interactions with the microenvironment are reviewed, and a survey is presented of the structure, regulation and putative (dys)function of the c-Ha-ras (onco)protein and its effects on tumor cell lines after transfection.

In Chapter 2 experiments are described in which nine human colorectal carcinoma cell lines were xenografted in nu/nu mice, either hetero- or orthotopically. Different modes of in vivo behavior, ranging from non-tumorigenic to tumorigenic, invasive and metastatic, were observed, depending on the site of xenografting. Because E-cadherin, urokinase- or tissue type-plasminogen activator, and integrin receptors have a role in intercellular adhesion, extracellular matrix degradation and cell-matrix interactions and are of importance for the invasive and metastatic cascade, the expression of these proteins was analyzed. With the exception of high expression of the $\alpha_{2} \mathfrak{B}^{\prime}$ integrin receptor, expression did not correlate with the in vivo invasive and metastatic behavior of tumor cells. Also, the ability to invade chick heart embryonic tissue, did not correlate with in vivo invasive and metastatic behavior. From these results, it was concluded that local tissue factors, in casu the microenvironment, play a role in the induction of genes responsible for invasion and metastasis.

Based on these results highly differentiated poorly tumorigenic $\mathrm{CaCo} 2$ cells and undifferentiated, tumorigenic but non-invasive $S W 480$ cells were selected to evaluate the genotypic and phenotypic consequences of transfection experiments with the c-Haras oncogene, particularly with regard to genetic instability, chromosomal integration site, tumorigenic and invasive potential, and differentiation.

In Chapter 3 the use of fluorescence in situ hybridization after chromosomal banding, induced by either hot banding or short trypsin treatment, is described in otder to identify chromosomal integration sites of transfected plasmid DNA. Nick translated DNA-probes labeled with digoxigenin-dUTP gave optimal fluorescence in situ hybridization signals in our hands. This method allowed rapid identification of chromosomal integration sites.

In Chapter 4 a cytogenetic analysis is described of transfected SW 480 cells. All cell lines demonstrated new clonal chromosomal abnormalities, but genetic instability was significantly increased only in c-Ha-ras oncogene transfected $\mathrm{SW} 480$ cells with an increased level of c-Ha-ras mRNA. The application of the method developed in chapter 3 demonstrated that Ras-containing plasmids integrated predominantly in new structurally rearranged chromosomes (five of eight). Three of five integration sites in new structurally rearranged chromosomes were localized at or near translocation breakpoints situated in telomeric regions. However, specific chromosomes were not involved in the chromosome rearrangements. It was concluded that the c-Ha-ras 
oncogene might increase the genetic instability and that chromosomal integration sites were especially associated with breakpoints in telomeric bands.

In Chapter 5 the phenotypic effects of $\mathrm{c}-\mathrm{Ha}$-ras oncogene transfection on $\mathrm{CaCo} 2$ and SW480 cells are described. CaCo 2 cells became highly tumorigenic, but not invasive, in nu/nu mice and induction of gelatinase activity was observed along with a possible increase in urokinase-plasminogen activator production. Specific changes in vitro in invasive capacity, tissue-type plasminogen activator production, proliferative potential, expression of $B$, integrin receptors, and differentiation were not noted. None of these parameters was altered in c-Ha-ras oncogene transfected SW480 cells, nor did the transfected cells become invasive. These results suggested that the c-Ha-ras oncogene might be involved in the progression of colorectal cancer, particularly in the induction of tumorigenic potential, but is most likely not required for the acquisition of invasive potential.

Chapter 6 describes in detail phenotypic characteristics of parental and c-Ha-ras oncogene transfected $\mathrm{CaCo} 2$ cells in vivo. The routine xenograft procedures with the parental $\mathrm{CaCo} 2$ cells did not yield xenografts in nu/nu mice. Therefore, $\mathrm{CaCo} 2$ cells were inoculated in collagen gel and by suppressing natural killer cell activity to obtain xenografts. Both $\mathrm{CaCo} 2$ and c-Ha-ras oncogene transfected $\mathrm{CaCo} 2$ cells displayed in vivo goblet cell, enterocytic, Paneth cell, and endocrine differentiation. The latter is of interest because of the scarcity of colorectal cancer cell lines with endocrine differentiation. Endocrine differentiation was not observed in vitro, neither under standard conditions nor with extracellular matrix components as differentiation inducers. It was concluded that $\mathrm{CaCo} 2$ cells and its c-Ha-ras oncogene transfected $\mathrm{CaCo} 2$ subline display in vivo similar differentiation characteristics, which included endocrine features. Therefore, ras overexpression does not alter the pattern of differentiation, but due to the favorable growth properties of the c-Ha-ras oncogene transfected $\mathrm{CaCo} 2$ cells in vivo, this subline may be a suitable model to study endocrine differentiation in colorectal cancer.

In Chapter 7 the results of the studies presented in the previous chapters are integrated with regard to current models employed to study colorectal carcinoma, and to the role of the c-Haras oncogene in: 1. Genetic instability in colorectal carcinoma and 2. Intracellular proliferation and differentiation pathways. 


\section{SAMENVATTING VOOR DE LEEK}

Kanker onstaat als het evenwicht tussen celaanmaak en celsterfte verstoord is. In normale omstandigheden is celsterfte gelijk aan celaanmaak, bij kanker is de laatste hoger dan de eerste, waardoor plaatselijk te veel weefsel ontstaat, een tumor. Suksesvolle behandeling van kanker is in hoge mate afhankelijk van het groeigedrag van de tumor. Is de groei alleen plaatselijk dan kan de tumor goed behandeld worden, bijwoorbeeld door volledige verwijdering via chirurgisch ingrijpen, en is de kans op genezing groot. Is de tumor echter ook doorgedrongen in omringend weefsel, zogenaamd invasief groeigedrag, dan is het waarschijnlijk dat door middel van behandeling niet alle tumorcellen verwijderd kunnen worden. Achtergebleven tumorcellen kunnen vervolgens weer uitgroeien tot tumoren. Bereiken invasieve tumorcellen de bloedbaan, dan kunnen ze verspreid worden naar andere delen van het lichaam, en daar uitgroeien tot nieuwe tumoren. Dit proces heet metastasering en is vaak verantwoordelijk voor de fatale afloop van kanker. Het groeigedrag van de tumor is dus van groot belang voor een suksesvolle behandeling van kanker: Inzicht in de faktoren betrokken bij: (1) het ontstaan van kanker; (2) de overgang van nietinvasieve naar invasieve tumorgroei en; (3) het metastaserings proces kunnen de behandeling van kanker mogelijk verbeteren.

Het ontstaan van kanker is waarschijnlijk toe te schrijven aan afwijkingen in eiwitten die normaal celgroei en celdeling reguleren. Een belangrijk groeiregulerend eiwit is het Ha-ras eiwit. Bepaalde afwijkingen in het Ha-ras eiwit resulteren in een eiwit dat kontinu aktief is en in staat blijkt te zijn om groei en deling van verschillende typen cellen te stimuleren. Het is mogelijk dat het afwijkende of mutante Ha-ras eiwit kanker veroorzaakt doordat het een cel kontinu prikkelt tot groei en deling, onafhankelijk van regulerende signalen van buitenaf. Deze visie wordt ondersteund door de aanwezigheid van genetische afwijkingen in het Ha-ras gen in verschillende typen tumoren, wat betekent dat deze tumorcellen afwijkende Ha-ras eiwitten produceren.

De overgang van niet-invasieve groei naar invasieve groei betekent dat een tumor cel in staat is zijn normale omgeving te verlaten. Cellen blijven op hun plaats doordat speciale eiwitten op het oppervlak van een cel, zogenaamde cel-adhesie molekulen, binden aan andere cel-adhesie molekulen op naast gelegen cellen. Tumorcellen met een verminderde expressie van deze eiwitten kunnen hus direkte omgeving waarschijnlijk makkelijker verlaten doordat ze minder hard plakken aan naast gelegen cellen. Daamaast is elk orgaan van het lichaam ingekapseld in een mengsel van grote eiwitten, de extracellulaire matrix, die voornamelijk bestaat uit collageen en laminine. De extracellulaire matrix geeft steun aan weefsels en scheidt organen van elkaar en van omringend weefsel. Bepaalde klassen van eiwitten, met name collagenases en plasmine en hun aktivatoren, kunnen de bouwstenen van de extracellulaire matrix afbreken. Vermoedelijk vergemakkelijkt een hoge expressie van collagenases en/of plasmine en hun aktivatoren de passage van een tumorcel door de extracellulaire 
matrix $_{w}$ wat nodig is om omringend weefsel te kunnen binnendringen. Dit wordt ondersteund door de waarneming dat hoge expressie van collagenases gepaard gaat met een verhoogd invasief vermogen van verschillende typen tumorcellen. Mogelijk speelt het Ha-ras eiwit ook een rol in de overgang van niet-invasieve naar invasieve groei, want een verhoogde expressie van mutant Ha-ras eiwit in bepaalde tumorcel typen is ook gekoppeld aan verhoogd invasief vermogen en aan verhoogde expressie van collagenase.

Metastasering is een nog grotendeels onbegrepen proces. Kenmerkend woor een groot aantal metastaserende tumor typen is een sterke toename in genetische afwijkingen. Dit betekent dat mutante eiwitten worden geproduceerd, en/of dat de produktie van bepaalde eiwitten verhoogd, verminderd of volledig stilgelegd kan zijn. Dit kan de groei en deling van cellen ingrijpend veranderen als het eiwitten betreft met een funktie in de régulering van groei en deling. Hiermee mogelijk verband houdend is het feit dat metastaserende tumoren vaak een lage differentiatiegraad vertonen. Dit betekent dat veel van de specifieke kenmerken van bijvoorbeeld darmcellen niet meer aanwexig zijn in cellen wan een metastaserende darmtumor. Ook in dit aspekt heeft het Ha-ras eiwit mogelijk een funktie, want mutant Ha-ras eiwit kan de differentiatiegraad van tumorcellen beïnvloeden, maar ook de genetische instabiliteit verhogen, waardoor de toename in het aantal genetische afwijkingen in tumorcellen wordt versneld.

In de vakgroep Pathologie houdt een onderzoeksgroep zich bezig met darmkanker. Dit is de meest voorkomende vorm van kanker in West Europa en de Verenigde Staten na longkanker en prostaatkanker bij mannen en borstkanker bij vrouwen, en is verantwoordelijk voor $10 \%$ van de sterfte aan kanker bij mannen en voor $14 \%$ van de sterfte aan kanker bij vrouwen. De behandeling van darmkanker is in de afgelopen decennia niet of nauwelijks verbeterd. Meer inzicht in het mechanisme van invasie en metastasering van darmtumorcellen kan behandeling van kwaadaardige tumoren verbeteren. De mogelijke relaties tussen mutant Ha-ras eiwit en (1) het ontstaan van kanker, (2) invasief, en (3) metastaserend gedrag in verschillen typen tumorcellen is reden om te veronderstellen dat het mutante Ha-ras eiwit eenzelfde betrokkenheid kan hebben bij darmtumoren. Ten einde dit nader te onderzoeken is het mutante Ha-ras eiwit ingebracht in humane darmtumorcellen en zijn de effekten bekeken op de genetische stabiliteit en op het gedrag van darmtumorcellen.

Hoofdstuk 1 beschrijft de kenmerken van invasieve en metastaserende cellen, en de struktuur en mogelijke funktie van het Ha-ras eiwit. Tevens worden de effekten van het mutante Ha-ras eiwit op verschillende typen tumorcellen beschreven.

Hoofdstuk 2 beschrijft het gedrag van menselijke darmtumor cellijnen onder versehillende kondities. Tumor cellijnen ontstaan uit tumorcellen, die verwijderd zijn uit een patiënt, en buiten het lichaam ( $=$ in vitro) doorgroeien en delen onder optimale voedings kondities. Het gedrag van verschillende darmtumor cellijnen werd bekeken na injektie van tumorcellen in het lichaam $(=$ in vivo) van een speciaal soort muis zonder immunologisch afweersysteem. Een gedeelte van de darmtumor cellijnen was 
invasief en metastaseerde, een gedeelte was invasief maar metastaseerde niet, en een gedeelte vormde tumoren die niet invasief en niet metastaserend waren. Het waarnemen van invasief groeigedrag en metastasering betekent dat dit model gehanteerd kan worden om invasie en metastasering te onderzoeken.

Vervolgens werd gekeken of er een verband was tussen in vivo invasief vermogen en in vitro expressie van cel-adhesie molekulen en plasminogeen aktivator. Er werd geen verband gevonden, wel bleek er een verband te zijn tussen in vitro expressie van zowel cel-adhesie molekulen als een plasminogeen aktivator met invasie in vitro. Uit de bovenstaande experimenten werd gekonkludeerd dat de direkte omgeving van een tumorcel een faktor is die invasief en metastaserend gedrag beïnvloedt.

Twee menselijke cellijnen werden geselekteerd voor verdere experimenten. CaCo 2 , een cellijn die geen tumoren vormde in de muis, en $S W 480$, een cellijn die nietinvasieve tumoren vormde in de muis. Het mutant Ha-ras gen werd ingebracht in CaCo 2 en SW480 cellen. Voor blijvende expressie van het Ha-ras eiwit moet het Ha-ras gen ingebouwd worden in het genetisch materiaal. Dit betekent dat het gen moet integreren in een chromosoom. Om na te gaan of integratie willekeurig plaatsvond of niet, werd de chromosomale integratie plaats zichtbaar gemaakt.

Hoofdstuk 3 beschrijft een methode warmee de chromosomale integratie plaats bepaald kan worden van het ingebrachte mutante Ha-ras gen.

Hoofdstuk 4 beschrijft de toepassing van deze methode op verschillende cellijnen van SW480 waar een mutant Ha-ras gen is ingebracht. Het blijkt dat het ingebrachte Ha-ras gen voornamelijk aangetoond wordt op nieuwe afwijkende chromosomen. De resultaten suggereren eveneens dat het inbrengen van het mutante Ha-ras gen de genetische instabiliteit van SW480 verhoogt.

Hoofstuk 5 beschrijft het gedrag en de expressie in vitro van verschillende eiwitten met een mogelijke rol in invasie en metastasering van CaCo 2 en SW480 cellen na het inbrengen van het mutante Ha-ras gen. Het blijkt dat $\mathrm{CaCo} 2$ cellen collagenases verhoogd tot expressie brengen en nu wel tumoren vormen in de muis. Deze tumoren zijn niet-invasief. Het inbrengen van het mutante Ha-ras eiwit sorteert geen effekt op het gedrag van SW480 cellen en brengt ook geen veranderingen teweeg in de expressie van de onderzochte eiwitten.

Hoofdstuk 6 beschrijft in detail de differentiatiegraad van de CaCo 2 tumoren in vivo. Het blijkt dat de differentiatie van de tumorcellen ondermeer afhangt van de direkte omgeving, maar lijkt niet beinwloedt te worden door het inbrengen wan cen mutant Ha-ras eiwit.

Hoofdstuk 7 integreert de data gepresenteerd in de voorgaande hoofdstukken. De belangrijkste effekten van het inbrengen van het mutante Ha-ras gen op menselijke darmtumorcellen is een verhoging van de genetische instabiliteit en een verhoging van het vermogen tot niet-invasieve tumor vorming in de muis. Deze resultaten suggereren een rol voor het mutante Ha-ras eiwit in het onstaan van darmkanker, maar geen rol in de overgang van niet-invasief naar invasief groeigedrag en van niet naar wel metastaserend gedrag. 


\section{DANKWOORD}

Dit proefschrift vormt de afronding van een periode die ik met veel plezler heb doorgebracht bij de Pathologie. Mijn hartelijke dank en grote waardering gat uit naar diegenen die op enigerlei wijze hun steen(tje) hebben bijgedragen. Een aantal wil ik graag bij naam noemen, zonder de andere mensen tekort te willen doen.

Beste Joop, zonder jou was dit proefschrift er niet gekomen. Het kwam tot stand in een zeer prettige samenwerking waar ik veel van heb opgestoken. De hartverwarmende steun en onvermoeibare inzet (ook na werktijd) zal ik niet vergeten. Fré, het proefschrift had zijn huidige vorm niet gekregen zonder de scherp analyserende inbreng van jou. De ontspannen wijze waarop deze inbreng werd geleverd maakte je tot de ideale supervisor op het promotie trajekt. Joep, jouw bijdrage was essentieel om de genetische data korrekt te interpreteren.

Met veel plezier denk ik terug aan de genetische sessies met Frank. Onder rook, muziek en verzuchtingen heb je de genetische afwijkingen in kaart gebracht. Beste Peter, met hetzelfde plezier denk ik terug aan de humorvolle en soepele samenwerking met jou op velerlei gebieden.

Grote bewondering heb ik voor Edith, jouw grenzeloze bekwaamheid gekoppeld aan uiterste hulpvaardigheid heeft het onderzoek veel goed gedaan. Deze eigenschappen bezaten meer mensen van de Pathologie (Orthopaedie), zoals Jacques Cleutjens, (Roel Kuijer), Cor Beek, Mat Rousch, Miek Havenith, Bert Schulte, Ton de Goeij, en het secretariaat door de jaren heen. De positieve opstelling van Jan-Willem Arends heeft de laatste loodjes lichter gemaakt.

Adriaan en Winand, jullie beider dynamische voortvarendheid resulteerde in hoofdstuk 6 , warvan akte.

Verder hebben de "Mannen van Jan" (Marc Oosterloo, Wessel Wittenburg, Marc Fischer) hun bijdrage geleverd. Patrick Marx, bedankt voor het aan elkaar knopen van veel losse eindjes in de laatste fase van het onderzoek. Léon en Marjolein, het was een genot om met jullie samen te werken. De enorme hoeveelheid kweekwerk kon ik rustig in jullie betrouwbare handen achterlaten (hetgeen ook gebeurde). Nicole, de vrouw die metafase preparaten sneller hybridiseert dan ze gespat kunnen worden. Blanka en Petra, jullie bijdrage kwam op een cruciaal moment.

Beste Marc Mareel en Hein Verspaget, de samenwerking gebeurde op een plezante wijze, waar ik veel van heb opgestoken. Joop Wiegant, je bent een onovertroffen leermeester geweest in het bijbrengen van niet-radioaktieve in situ hybridisatic technieken.

Beste Marc Stuart en Paul Bomans, jullie inbreng in de doka bleef me soms duister maar hielp wel degelijk om goede foto's te verkrijgen. Ook de audiovisuele dienst is zeer gewaardeerd voor het geleverde fotowerk, met name Francis van der Lubbe. Tevens bedank ik de Dienst Automatisering en Orthopaedie voor het beschikbaar stellen van HPL4's. Ruud Leliveld gaf op plezierige wijze de goede tips on het proefschrift drukklaar te krijgen. 
De beoordelingskommissie, aangevuld met Goos van Muijen, bedank ik woor het doonemen van het manuscript en het geleverde kommentaar. Frans, bedankt voor het voorzitterschap.

Uiteindelijk is onderzoek een groepsgebeuren. Een goede sfeer is daarbij een eerste vereiste. Die ontstaat natuurlijk door de inbreng van alle mensen van de Pathologie, maar voor mij in het bijzonder door Ellen als ideale werkkamergenote, bovenbuurvrouw, en mede-promovenda, Robert als biljarter, en Anneke ondermeer als "Zuidelijk Toneel" fan. Tenslotte wil ik benadrukken, Mieke, dat jouw steun in de afgelopen jaren erg belangrijk is geweest voor mij.

Het zijn de mensen die 't " $m$ doen, dit waren de mensen die 't ' $m$ deden. 


\section{Curriculum vitae}

1963 Geboren te Drachten

1982 Eindexamen Atheneum B

Het Drachtster Lyceum, Drachten

1982-1988 Studie Scheikunde, Afstudeerrichting Biochemie Rijks Universiteit Groningen

1988-1992 Assistent In Opleiding bij de vakgroep Pathologie Rijksuniversiteit Limburg

1992-1993 Afronding proefschrift

1993-1994 Vervulling van de gewone vervangende dienst bij de vakgroep Fysiologie, Rijksuniversiteit Limburg 


\section{PUBLICATIONS}

\section{Artikelen}

B. Neuteboom, W. Dokter, J. wan Gijsen, H. Rensink, J.E. de Vries and J.J. Beintema, Partial amino acid sequence of a hemocyanin subunit from PALINURUS VULGARIS. Comp. Biochem. Plyysiol, 94B: $593-597,1989$.

J.N.J. Philipsen, J.E. de Vries, J. Samallo, C. van Dijk, A.C. Arnberg, and G. AB. Characteriwation of a polymorphism in the 3' part of the chicken vitellogenin gene. J. Mol. Exol. 28: 185-190, 1989.

J.E. de Vries, F.H.A.C. Komips, J. Wiegant, P.M. Moerkerk, N. Senden, B. Schutte, J.P.M. Geraedts, F.T. Bosman, and J. ten Kate. Chromosomal localization of transfected genes by a combination of hot banding and fluorescence in situ hybridization. J. Histochem. Cytochem. 40: 1053-1058, 1992.

A.P. de Bruine, J.E. de Vries, W.N.M. Dinjens, E.P.M. van der Linden, M. Pijls, J. ten Kate, and F.T. Bosman. Human Ha-Ras transfected CaCo-2 cells as a model for endocrine differentiation in the large intestime. Differentiation, 53: $511-60,1993$.

J.E. de Vries, F.H.A.C. Kornips, P. Marx, F.T. Bosman, J.P.M. Geraedts, and J. ten Kate. Transfected c-Ha-ras oncogene enhances karyotypic instability and integrates preflominantly in aberrant chromosomes. Cancer Genet. Cytogenet, 65: 35-43, 1993.

I.E de Vries, M. van Driel, P. Marx, E.P.M. van der Linden, L.G.A de Bruin, P.M. Moerkerk, H.W. Vorspaget, F.T. Bosman, and J. ten Kate. Phenotypic analysis of $\mathrm{CaCO} 2$ and $\mathrm{SW} 480$ cell lines transfected with the c-Ha-ras oncogene. Submitted.

J.E. de Vries, W.N.M. Dinjens, H.W. Verspaget, E.P.M. van der Linden, A.P. de Bruïne, M.M. Mareel. F.T. Bosman, and J. ten Kate. Behavior of orthotopic human colorectal carcinoma xenografts in relation to in vitro invasion. Submitted.

Abstracts.

J.E. de Vries, P.M. Moerkerk, L.G.A. de Bruine, W.N.M. Dinjens, E.P.M, wan der Linden, I. Wiegant, M. van Driel, J. ten Kate and F.T. Bosman. Characterization of colon eancer cell lines after transfection with the c-Ha-ras oncogene. Clin. Exp. Metast. 8 (suppl. 1): 39, 1990.

J.E. de Vries, P.M. Moerkerk, L.G.A. de Brüne, W.N.M. Dinjens, E.P.M. van der Linden, J. Wiegant, M. van Driel, J. ten Kate and F.T. Bosman. Growth characteristics of colon tumor ecll lines after transfection with the c-Ha-ras ancogene. Eur. J. Cell Biol. 53 (suppl. 1): 34, 1990.

A. de Brüne, Il de Vries, W. Dinjens, E wan der Linden, M. Pijls, J. ten Kate, F. Bosman. RAStransfected $\mathrm{CaCo}-2$ cells: $\mathrm{A}$ model for endocrine differentiation in the large intestine. Histochemical J. 24: 612, 1992 .

J.E. de Vries, A.P. de Bruine, W.N.M. Dinjens, E.P.M van der Linden, H.W. Verspaget, F.T. Bosman and $J$. ten Kate. In Vitro expression of $\mathrm{L}-\mathrm{CAM}$ and $\mathrm{u}-\mathrm{PA}$ of human colorectal carcinoma cells is not related to their In Viwo growth behavior. Histochemical $J .24: 613,1992$. 